\title{
Átmenetifém-aminosav komplex-CaAl-réteges kettős hidroxid kompozitok készítése, szerkezetvizsgálatuk és katalitikus alkalmazásaik
}

\author{
PhD értekezés \\ Varga Gábor
}

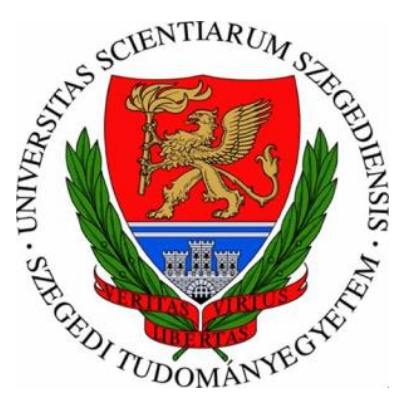

Témavezetők:

Pálinkó István, egyetemi tanár Sipos Pál, egyetemi tanár

Környezettudományi Doktori Iskola Természettudományi és Informatikai Kar Szegedi Tudományegyetem

Szeged

2017 


\section{Tartalomjegyzék}

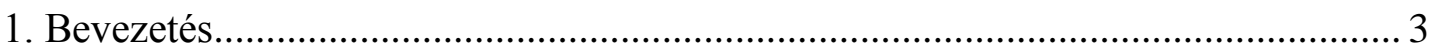

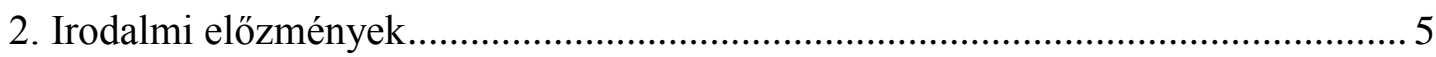

2.1. A réteges kettős hidroxidok szerkezete, előállítási és szerkezetmódosítási

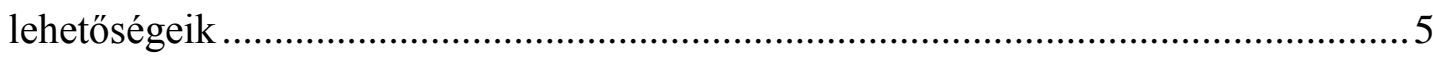

2.1.1. Az LDH-k felépítése, tulajdonságaik és a rétegközi anionok ........................5

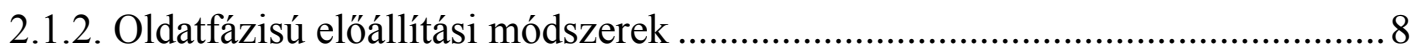

2.1.3. Mechanokémiai és szonokémiai szintézismódszerek ................................ 10

2.1.4. Az interkalálás lehetőségei ...................................................................... 11

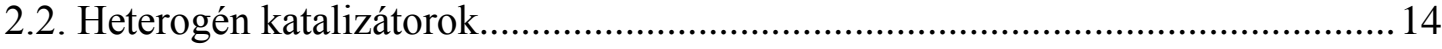

2.2.1. Homogén katalizátorok heterogenizálása .................................................. 15

2.2.2. Heterogén katalitikus reakciók.................................................................. 17

2.3. Komplex anionok beépítése réteges kettős hidroxidokba ..................................2 23

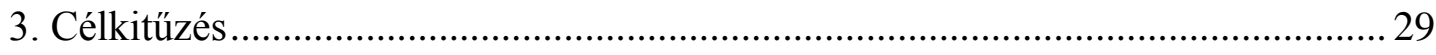

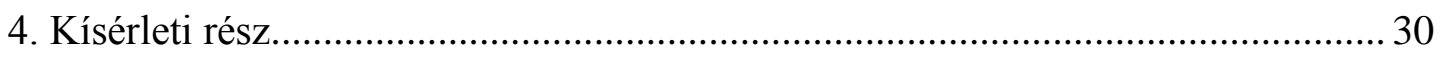

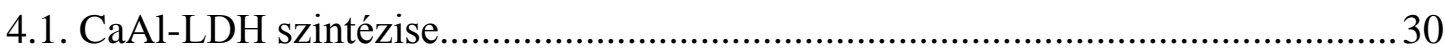

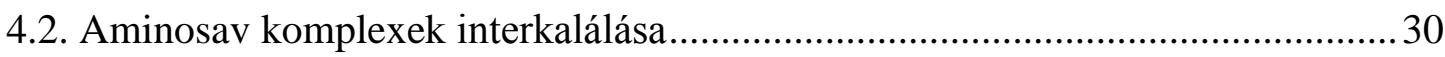

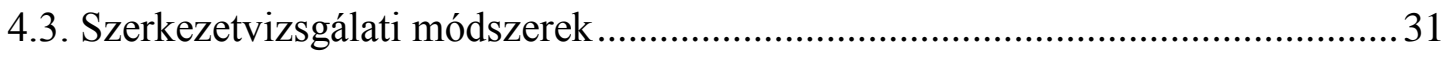

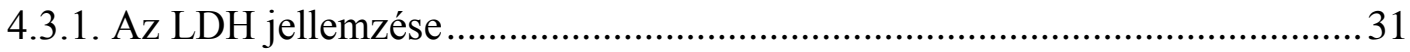

4.3.2. Mennyiségi meghatározás ........................................................................ 31

4.3.3. A komplexek szerkezetvizsgálata, az interkalálás bizonyítása.......................32

4.3.4. Molekuláris szintü modellalkotás .............................................................. 36

4.4. A katalitikus aktivitás vizsgálata ........................................................................ 37

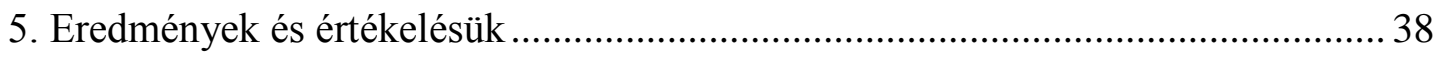

5.1. Aminosav komplexek kiépítése CaAl-LDH rétegei között.................................38

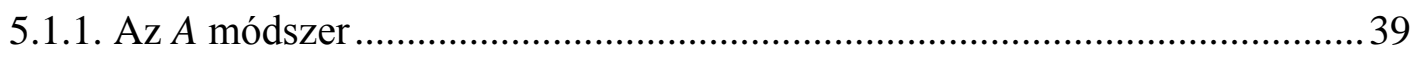

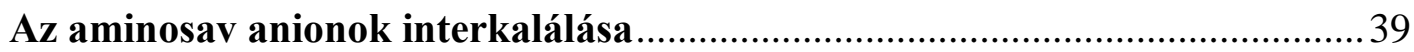




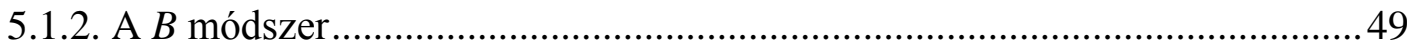

5.2. A sikeresen kiépített interkalált szerkezetek ..................................................50

5.3. A beépített komplexek szerkezetazonosítása és mennyiségi meghatározása.......63

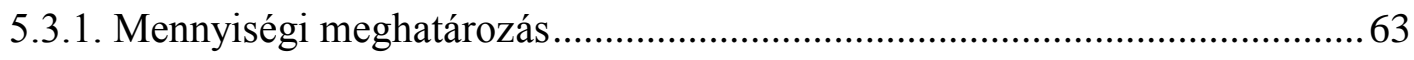

5.3.2. Távoli IR és Raman spektroszkópiai vizsgálatok ......................................63 63

5.3.3. ESR spektrumokból nyerhető szerkezeti információk................................67

5.3.4. Az XAS spektrumok értelmezése …........................................................ 70

5.3.5. Az interkalált komplexek feltételezett szerkezete....................................... 77

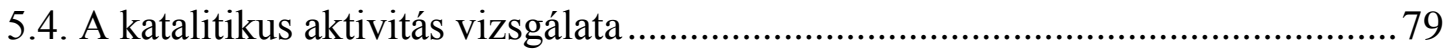

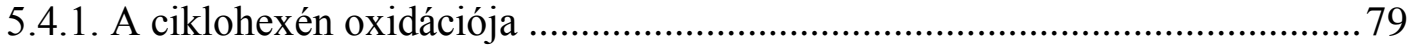

5.4.2. A kompozitok aktivitása az Ullmann-típusú éterképzésben ......................... 85

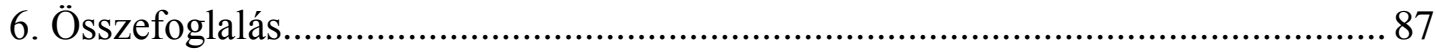

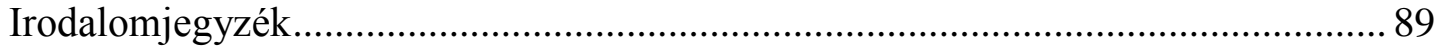

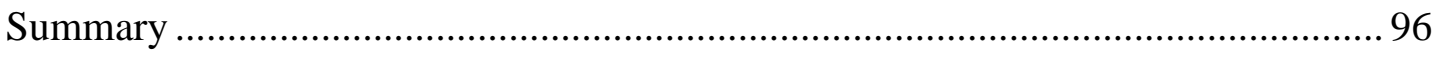

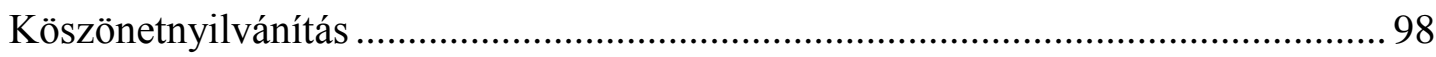

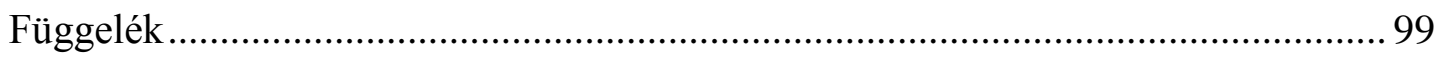




\section{Bevezetés}

A vegyipar által előállított termékek jelentős része katalitikus szintézisúton készül. Éppen ezért nagyszámú homogén illetve heterogén katalizátort állítottak elő. A katalitikus reakciók nagyobb atomhatékonyságúak, így jóval környezetbarátabbak, mint a sztöchiometrikus reakciók. A homogén katalizátorok jelentős része fémorganikus vegyület, ha szerves kémikusként tekintünk rájuk, illetve fémkomplex, ha szervetlen kémikusként szemléljük. Általában ezek a vegyületek nagyon aktív és szelektív katalizátorok, ám visszanyerésük nehéz, ha nem lehetetlen, így a többszöri felhasználhatóság előnye igen gyakran elvész. Újszerű megoldásnak számít katalitikusan aktív szerves-szervetlen kompozitok előállítása úgy, hogy a fémorganikus vegyületeket szilárd hordozóhoz kapcsolják. Szerencsés esetben ekkor a katalizátorok aktivitása és szelektivitása nem vagy nem nagyon változik, ugyanakkor a mostmár heterogén katalizátor könnyen visszanyerhető, és regenerálás után újrafelhasználható, növelve az átalakulások atomhatékonyságát, ezzel hozzájárulva az átalakulások környezetbarátabbá tételéhez.

Szerves-szervetlen kompozitok sokféle reakcióban vehetnek részt katalizátorként, többek között lehetnek redoxi folyamatok katalizátorai is. Korábban sikerrel alkalmaztak biomimetikus komplexeket telítetlen vegyületek oxidációs reakcióiban, valamint alkoholok dehidrogénezésében. Ezek a komplexek gyakran aminosavak vegyértékváltó átmeneti fém ionokkal képzett komplexei voltak, amelyek mintájául az enzimek kofaktorai szolgáltak.

A tapasztalat az volt, hogy sok esetben a heterogenizáláshoz felhasznált hordozó sajátságai is erősen befolyásolták a katalitikus aktivitást és a szelektivitást. Ezért alkalmaztak különböző karakterü hordozókat: szerves polimereket, módosított szilikagélt, vagy ioncserélő sajátságú anyagokat. A réteges kettős hidroxidok (angol nevének rövidítése alapján: LDH) ioncserélő sajátságú anyagok. Réteges szerkezetük pozitív töltésü, ezt a töltést egyszerübb vagy összetettebb, részlegesen van teljesen hidratált anionok kompenzálják. Ezek az anionok kisebb-nagyobb nehézséggel cserélhetők. Az LDH-k felhasználhatók katalizátor hordozóként, katalizátor prekurzorként, sőt katalizátorként is. Hordozóként való alkalmazásuk azért is lehet elönyös, mert a rétegközi térbe beépített (interkalált) egyszerübb vagy bonyolultabb anionok különleges viselkedést mutathatnak, kimosódásuk erősen gátolt, és a behatárolt térrész lehetőséget nyújt alakszelektív reakciók lejátszódására. 
Katalizátoraink előállításához egy ilyen réteges kettős hidroxidot alkalmaztunk, amelyekbe vegyértékváltó tulajdonságú átmeneti fém ion-aminosav komplexeket építettünk. A kapott kompozitok katalitikus aktivitását, szelektivitását és újrafelhasználhatóságát redoxi, illetve kapcsolási reakciókban teszteltük. 


\section{Irodalmi elózmények}

\subsection{A réteges kettős hidroxidok szerkezete, előállítási és szerkezetmódosítási}

\section{lehetőségeik}

2.1.1. Az LDH-k felépítése, tulajdonságaik és a rétegközi anionok

A réteges kettős hidroxidokat (LDH) szokás hidrotalcitszerü anyagoknak nevezni. A hidrotalcit nem más, mint a magnézium és alumínium hidroxikarbonátja, amelynek a szerkezete a brucitéból származtatható. ${ }^{1}$ Ebben a konkrét esetben a kétértékủ fém ion, azaz a $\mathrm{Mg}(\mathrm{II})$, hidroxidjának rácsába izomorf helyettesítéssel épülnek be a háromértékű fém ionok, azaz az Al(III)-ionok. A rétegekben oktaéderes elrendeződés alakul ki a fém ionok körül. ${ }^{2}$ A rétegek közé töltéskompenzáló anionok épülnek be (1. ábra).

Ugyanakkor valójában a hidrotalcitszerü vagy brucitszerü réteges kettős hidroxidok egy gyüjtőnév, ami több mint 44 ásványból álló vegyületcsoportot takar. Ez a „szupercsoport” felosztható további hat alcsoportra úgymint hidrotalcit, quintinit, fougerit, woodwardit, kualsztibit, glukocerinit, wermlandit és hidrokalumit. ${ }^{3}$ A CaAl-LDH, amivel munkánk során foglalkoztunk, a hidrokalumit alcsoportba tartozik. Ennek az ásványnak a szerkezete eltér a hidrotalcitétól, egyrészt abban, hogy a Ca:Al arány rögzített, 2:1, másrészt a kalcium iont, annak nagy mérete miatt, a rácsban hét hidroxid ion veszi körül. ${ }^{4}$

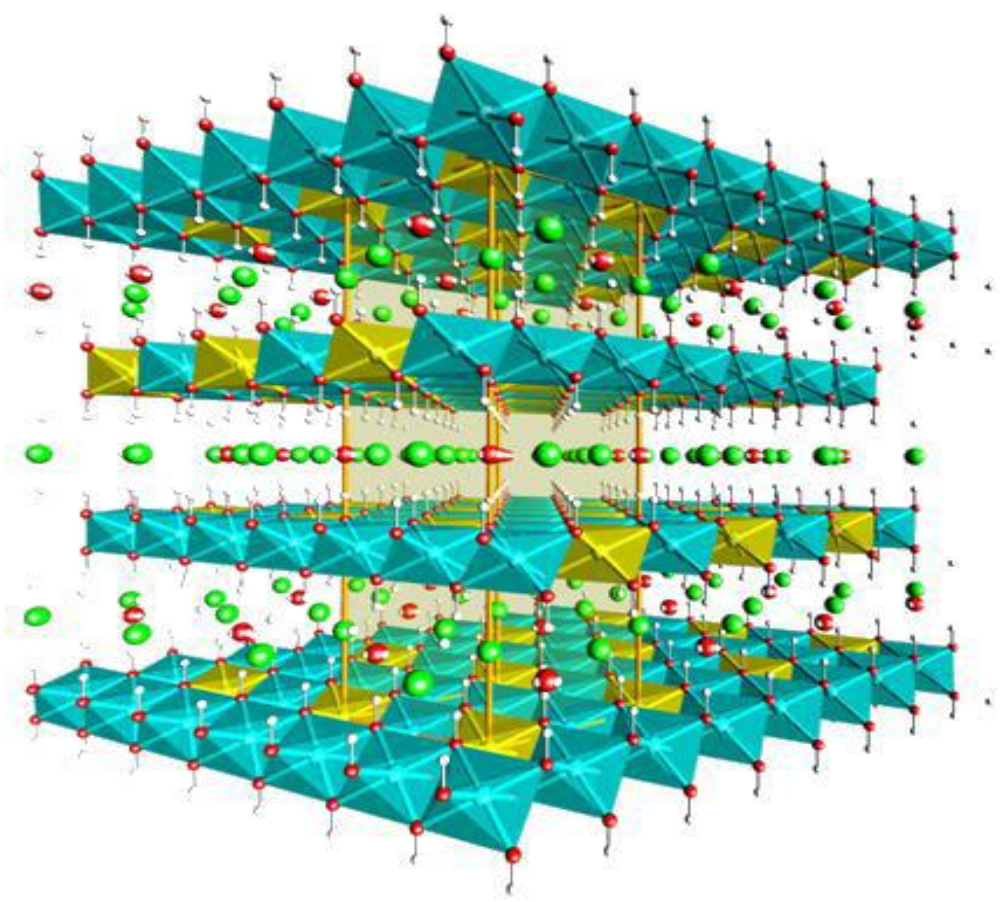

1. ábra: A réteges kettős hidroxidok felépítésének sematikus ábrázolása. ${ }^{5}$ 
Ugyanakkor a fentiek csak egy közelítő képet adnak az LDH szerkezetéről és összetételéről. Például, egy adott LDH elnevezés sem feltétlenül egyetlen ásványt jelent, hiszen mindegyik LDH-nak vannak politípusai. Külön típusnak számítanak a különböző összetételü és szerkezetủ ásványok, mint például a $\operatorname{Mg}_{6} \mathrm{Al}_{2}(\mathrm{OH})_{12}\left(\mathrm{CO}_{3}\right) \times 4 \mathrm{H}_{2} \mathrm{O}$, ami a hidrotalcit 3R politípusa, és romboéderes szerkezettel rendelkezik, valamint a $\mathrm{Mg}_{6} \mathrm{Al}_{2}\left(\mathrm{CO}_{3}\right)(\mathrm{OH})_{16} \times 4 \mathrm{H}_{2} \mathrm{O}$, ami a hidrotalcit $2 \mathrm{H}$ politípusa és oktaéderes a szerkezete. ${ }^{5}$ Tovább árnyalja a képet az is, hogy az LDH-k esetében a fém ionok körül kialakuló geometria sem mindig szabályos. Ugyanis azt már korábban leírták, hogy oktaéderesnek gondolt rétegek esetében is erősen torzulhat a szerkezet. A szabályos oktaéderes szerkezetek pontcsoportja, $\mathrm{O}_{\mathrm{h}}$, ugyanakkor a NiAl-LDH esetében $\mathrm{D}_{3 \mathrm{~d}}$ a rétegek szimmetriája. $^{6}$

Néhány esetben az izomorf helyettesítés sem úgy zajlik, mint a hidrotalcit esetében. A cinkszegény ZnAl-LDH esetében például első lépésben az alumínium-hidroxid rács alakul ki, és ebbe a rácsba épülnek be a cink ionok. ${ }^{7}$

Habár a fentiek alapján látható, hogy egy igen szerteágazó csoportról van szó, ugyanakkor számos közös tulajdonsággal rendelkeznek. Nem véletlen, hogy sikerült felírni egy általános összegképletet, ami a következő: $\left[\mathrm{M}(\mathrm{II})_{1-\mathrm{X}} \mathrm{M}(\mathrm{III})_{\mathrm{X}}(\mathrm{OH})_{2}\right]^{\mathrm{X}+}\left[\mathrm{X}_{\mathrm{X} / \mathrm{m}}^{\mathrm{m}-} \times \mathrm{nH}_{2} \mathrm{O}\right]^{\mathrm{X}-}$.

A képlet első tag írja le a rétegek összetételét, míg a rétegközi teret hivatott leírni a második tag. ${ }^{8} \mathrm{Az}$ is jól látható az összegképletből, hogy a rétegközi térben nem csupán anionok helyezkednek el, hanem víz is. A rétegek a legtöbb esetben kétértékü $\left(\mathrm{Ca}^{2+}, \mathrm{Mg}^{2+}\right.$, $\left.\mathrm{Ni}^{2+}, \mathrm{Mn}^{2+}, \mathrm{Cu}^{2+}, \mathrm{Fe}^{2+}\right)$, valamint háromértékủ $\left(\mathrm{Fe}^{3+}, \mathrm{Al}^{3+}, \mathrm{Mo}^{3+}, \mathrm{Cr}^{3+}, \mathrm{Ga}^{3+}, \mathrm{Co}^{3+}\right)$ fém ionokból épülnek fel. ${ }^{9}$ Korábban sikeresen állítottak elő réteges kettős hidroxidokat, amelyek négy vegyértékű $\left(\mathrm{Sn}^{4+}, \mathrm{Zr}^{4+}\right)$ valamint egy vegyértékü $\left(\mathrm{Li}^{+}\right)$ionokat tartalmaztak. ${ }^{10-12}$ Azt, hogy mely fém ionokból lehet sikerrel LDH-t szintetizálni, nagymértékben befolyásolják az ionsugarak, amelyeknek hasonlóaknak kell lenni ahhoz, hogy végbemenjen az izomorf helyettesítés. Így nem véletlen, hogy leginkább a periódusos rendszer harmadik és negyedik periódusába tartoznak azok a fém ionok, amelyekből sikeresen állítottak elő LDH-t. Azonban nem ez az egyetlen befolyásoló tényező, hiszen a különböző kiindulási anyagok oldhatósága, az oldatban kialakuló esetleges melléktermékek, valamint a fém ionok redoxi tulajdonságai mind meghatározóak lehetnek az LDH leválásának szempontjából. ${ }^{13}$

A memória effektus, valamint a delamináció is jellemző az összes réteges kettős hidroxidra. Amennyiben (egy nem túl magas hőmérsékletü) hőkezelés hatására a szerkezet 
összeomlik, egy olyan vegyes oxidszerkezet alakul ki, amelyböl hidratáló körülmények között a réteges szerkezet visszaalakítható. Ez a „küszöbhőmérséklet” minden LDH esetében más és más, de általában $500{ }^{\circ} \mathrm{C}$ körüli. ${ }^{14} \mathrm{~A}$ delamináció során, azt tapasztalhatjuk, hogy bizonyos oldószerekben ( $N, N$-dimetil-formamid - DMF, dimetilszulfoxid - DMSO, stb.) a rétegek annyira eltávolodnak egymástól, hogy megszűnik a réteges szerkezet, de ez az állapot csak addig áll fenn ameddig a rendszerből el nem távolítjuk a delamináló oldószert. ${ }^{15}$

Az LDH-k legfontosabb közös tulajdonsága az, hogy anioncserélőként viselkednek. Igen nagyszámú aniont sikerült már beépíteni réteges kettős hidroxidokba. Ezeket különböző típusú csoportokra oszthatjuk fel ${ }^{5}$ :

- halogenidek $\left(\mathrm{F}^{-}, \mathrm{Cl}^{-}, \mathrm{Br}^{-}, \Gamma\right)$,

- nemfémes oxoanionok $\left(\mathrm{BO}_{3}{ }^{3-}, \mathrm{CO}_{3}{ }^{2-}, \mathrm{NO}_{3}{ }^{-}, \mathrm{Si}_{2} \mathrm{O}_{5}{ }^{2-}, \mathrm{HPO}_{4}{ }^{2-}, \mathrm{SO}_{4}{ }^{2-}, \mathrm{ClO}_{4}{ }^{-}\right.$, stb.),

- oxo- és polioxo-metallát anionok $\left(\mathrm{VO}_{4}{ }^{3-}, \mathrm{CrO}_{4}{ }^{2-}, \mathrm{MnO}_{4}{ }^{-}, \mathrm{Mo}_{7} \mathrm{O}_{24}{ }^{6-}, \mathrm{stb}\right.$.),

- átmeneti fémek anionos komplexei $\left(\mathrm{Fe}(\mathrm{CN})_{6}{ }^{2-}, \mathrm{stb}\right.$.),

- szerves anionok $\left(\mathrm{CH}_{3} \mathrm{COO}^{-}, \mathrm{C}_{2} \mathrm{O}_{4}{ }^{2-}, \mathrm{C}_{6} \mathrm{H}_{5} \mathrm{SO}_{3}{ }^{-}\right.$, stb. $)$,

- anionos polimerek (poli-(sztirol-szulfonát) (PSS), poli-(vinil-szulfonát) (PVS), poliakrilát, stb.).

Két fontos paraméter befolyásolja azt, hogy mennyire erősen kötődik az anion a rétegekhez. Egyrészt az anion mérete, másrészt töltéssürüsége az, ami meghatározza a kötés erősségét. Ezek alapján szervetlen anionokra felállítottak egy liotróp sort, amelynek az elején a legerősebben kötődő karbonát ion, a végén pedig a perklorát ion áll: $\mathrm{CO}_{3}{ }^{2-}>$ $\mathrm{SO}_{4}{ }^{2-}>>\mathrm{OH}^{-}>\mathrm{F}^{-}>\mathrm{Cl}^{-}>\mathrm{Br}^{-}>\mathrm{NO}_{3}{ }^{-}>\mathrm{I}^{-}>\mathrm{ClO}_{4}{ }^{-16}$ Ez a sor meghatározza az anionok egymáshoz viszonyított lecserélhetőségét is, vagyis a sorban elörébb álló anion képes kiszorítani a sorban utána következőt. A karbonát ion tulajdonképpen a klasszikus, oldatfázisú ioncserélő módszerek szempontjából cserélhetetlen, éppen ezért kell inert atmoszférát alkalmazni minden olyan esetben, amikor ioncserére, a tématerületen használt szakszóval élve interkalálásra kívánjuk felhasználni az LDH-kat.

Az LDH-nak sokféle felhasználási módját kutatták már az elmúlt évtizedekben. Alkalmazták már őket szelektív adszorbensként, gyógyszerek hordozójaként, különbözö katalitikus folyamatokban katalizátorként, katalizátor prekurzorként és katalizátor hordozóként. ${ }^{17-21}$ A későbbiekben a katalitikus felhasználásukra jelentős számú példát fogunk bemutatni. 


\subsubsection{Oldatfázisú előállítási módszerek}

Manapság a legtöbb tanulmányozott LDH szintézise, mint amilyen a CaAl-LDH-é is, rutinfeladatnak számít. Nagyszámú, egymástól kismértékben eltérő módszer leírása található meg az irodalomban. A következőkben a leggyakrabban alkalmazott oldatfázisú módszerek bemutatására fogunk koncentrálni.

\section{Együttes lecsapás}

A módszernek két különböző formája létezik. Mindegyikük rendelkezik elönyökkel és hátrányokkal is. A módszer alkalmazása során először egy közös fémsó-oldatot kell elkészíteni, és ezek után van két választási lehetőségünk. Amennyiben állandó pH-t állítunk be, és a szintézis során a pH-t folyamatosan ellenőrizzük és változás esetén kis részletekben $\mathrm{NaOH}$-oldatot adagolunk az oldathoz, azaz a módszer meglehetősen lassú és folytonos figyelmet igényel (hátrány), akkor jó kristályossági fokú LDH-t kaphatunk (elöny). Ha nem tartjuk állandó értéken a pH-t, hanem nagy koncentrációjú lúgoldathoz öntjük a fémsó oldatot, a folyamat nagyban leegyszerüsödik, és rövidebb idő alatt kivitelezhetővé válik (előny), a kapott termékünk azonban kevésbé lesz kristályos (hátrány). ${ }^{5}$

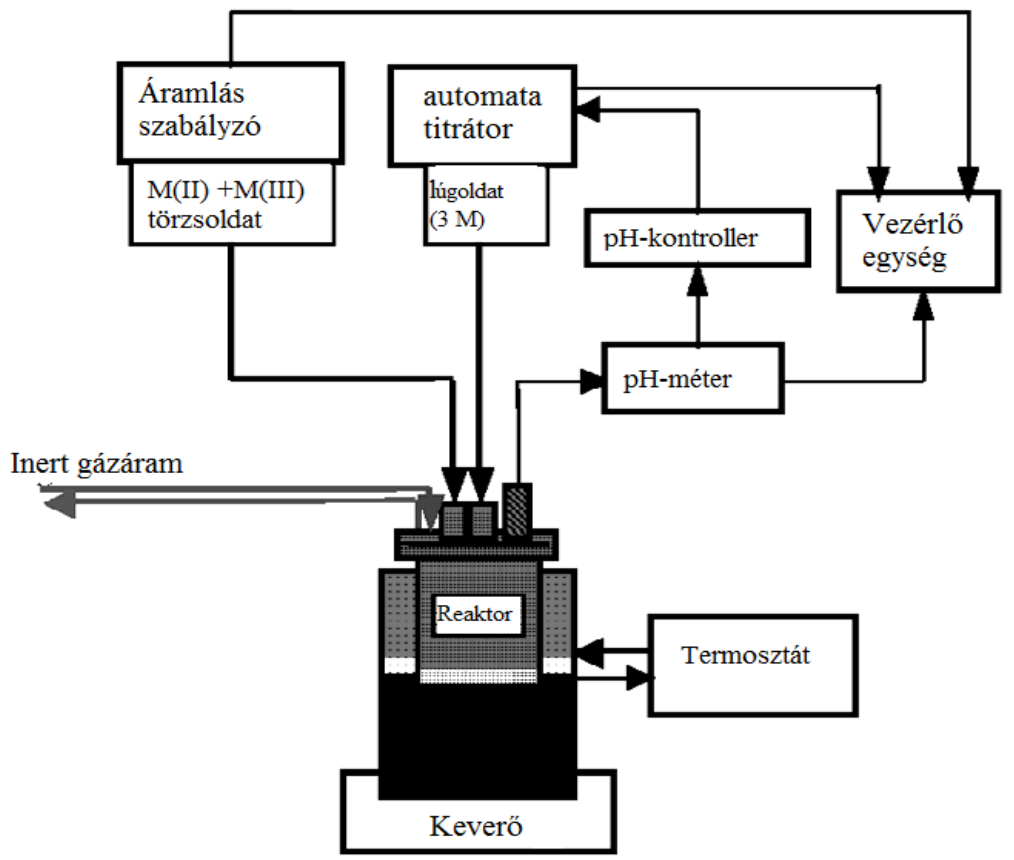

2. ábra: Az együttes lecsapáshoz kivitelezéséhez szükséges reaktor felépítése. ${ }^{5}$

Ugyan a legkritikusabb paraméter a $\mathrm{pH}$ az együttes lecsapás mindkét változata esetén, vannak egyéb reakcióparaméterek, amelyek változtatásával növelhető a 
kristályossági fok és csökkenthető a leváló melléktermékek száma. Ezek a paraméterek az alkalmazott hőmérséklet, a lúgoldat és a fémsó-oldat koncentrációja, a reaktor típusa (állóágyas vagy áramlásos), az öregítés időtartama, $s t b .^{22}$

Az öregítés azt jelenti az LDH-k esetében, hogy a csapadék leválása után tovább folytatódik az elegy kevertetése illetve hőkezelése, a kívánt termék tisztaságának és kristályosságának fokozására. Ez akár 24-168 órát is eltarthat, holott az LDH kialakul maximum 30 perc alatt. Hasonló hatás érhető el egyéb, reakció utáni kezelésekkel. Az egyik legismertebb módszer a hidrotermális kezelés, aminek hatására, magas nyomáson és hömérsékleten a réteges anyag újrakristályosodik.

A módszer hátránya az, hogy a folyamat során néhány paraméter szabályozhatatlan vagy legalábbis nehezen szabályozható. Nem lehet nyomon követni az ionerősség változását, valamint nagyon nehéz a pontos keverési (vagy áramlási) sebességet meghatározni. Továbbá a módszer nem alkalmazható olyan fém ionok esetében, amelyek az adott körülmények között stabilis komplexet képeznek, vagy redoxi reakcióban átalakulnak.

$\mathrm{Az}$ együttes lecsapás alkalmas lehet anionok interkalálására is. Korábban már halogenideket, szervetlen nemfémes anionokat és oxometallát anionokat is sikerrel építettek be különféle LDH-k rétegei közé. A kivitelezést nem befolyásolja jelentősen az anionok beépítése, mivel csupán a kiindulási oldathoz kell hozzáadnunk a beépíteni kívánt aniont. Ugyanakkor néhány körülmény megakadályozhatja az interkalációt; ezek a következőek ${ }^{23}$ :

- az interkalálandó nem oldódik az adott közegben,

- komplexképzés vagy redoxi reakció játszódik le a ligandum és bármelyik fém ion között,

- a ligandum érzékeny a lúgos közegre.

\section{Karbamid hidrolízis módszere}

Hasonló alapokra épül, mint az előzőekben leírt módszer, csak ebben az esetben indirekt pH-szabályozás történik. A folyamat során ugyanis a kiindulási elegy tartalmazza a karbamidot, és ezt az elegyet hőkezeljük kevertetés közben. Az alkalmazott hőmérséklet hatására a karbamid bomlani kezd, és a teljes bomlás végére a $\mathrm{pH}=9,35$-ra áll be. ${ }^{24} \mathrm{~A}$ módszer előnyei között lehet felsorolni azt, hogy kiemelkedő kristályossági fokú LDH-k állíthatók elő, illetve azt, hogy a hőmérséklet változtatásával szabályozni lehet a részecskeméretet. ${ }^{25}$ Minél alacsonyabb a beállított hőmérséklet, annál kisebb lesz az 
átmérő. ${ }^{26}$ Ugyanakkor nem lehet alkalmazni a technikát olyan fém ionok esetében, ahol 9,35-nél magasabb pH-t kellene alkalmazni. A módszer további hátránya az, hogy karbonát ion épül be minden esetben a rétegek közé, ami lehetetlenné teszi az interkalálást (oldatfázisban).

\subsubsection{Mechanokémiai és szonokémiai szintézismódszerek}

$\mathrm{Az}$ irodalomban csak az utóbbi időben találhatunk példákat mechanokémiai LDH szintézisekre, manapság azonban egyre elterjedtebbek ezek a módszerek is. Ezen a módon az első réteges kettős hidroxidot, ami egy MgAl-LDH volt, 2007-ben szintetizálták. ${ }^{27} \mathrm{Az}$ első szintézisek még az úgynevezett egylépéses szintézisutat alkalmazták, és jó kristályossági fokú hidrotalcitokat voltak képesek előállítani. A folyamat során a fémek hidroxidjait használták, és a mechanikai energiaközlés hatására játszódott le az izomorf helyettesítés.

A későbbiekben továbbfejlesztették a módszert, és egy kétlépéses szintézist kezdtek el alkalmazni. Első lépésként, az úgynevezett száraz őrlés során, a fémsókkal, amelyek ebben az esetben már nem feltétlenül csak hidroxidok lehettek, mechanikai energiát közöltek. Az első lépés után megvizsgálták a kialakuló terméket, és megállapították, hogy a sók kristályvíz-tartalma nem biztosított kellő mennyiségű hidroxid iont az LDH leválásához. ${ }^{28}$ Tehát, tulajdonképpen az első lépésben csupán a minták mechanikai aktiválása történt meg. Ez azt jelenti, hogy hibahelyek képződtek a kristályrácsban, és a reaktív felület is megnövekedett, ami elősegítette az LDH kialakulását. A második lépésben, amit nedves örlésnek neveznek, vizet adtak a rendszerhez és sikeresen választottak le LDH-t. Ezzel a módszerrel szinte az összes, korábban publikált LDH-t sikerült fázistiszta, vagy közel fázistiszta állapotban, jó kristályossági fokkal előállítani. ${ }^{29,30}$ A módszer nagy előnye az egylépéses szintézisúttal szemben az, hogy olyan fémek esetében is alkalmazható, amelyek hidroxidjai nem stabilisak, és sokkal kevesebb melléktermék keletkezésére lehet számítani. Sikerült ezzel a módszerrel Ca(II)Sn(IV)LDH-t is elöállítani, ami különlegességnek számít. ${ }^{11}$

Ma már fellelhetők olyan publikációk, amelyek leírják azt, hogy használtak mechanikai energiaközlést (száraz őrlés), de a szintézis végén oldatfázisú utókezeléssel sikerült a fázistiszta réteges anyagot előállítani. Ezt a módszert hívják mechanohidrotermális módszernek. ${ }^{31}$ A mechanokémiai módszereket általában a következő körülmények befolyásolják:

- száraz/nedves őrlés időtartama, 
- minta/golyó tömegarány,

- hozzáadott víz/lúg mennyisége,

- alkalmazott atmoszféra.

Az ultrahang besugárzással történő kezelést az LDH-k szintetizálása során sokáig csupán kisegítő módszerként alkalmazták, mivel a kavitációs buborékok megszünésekor a keverés nagyon hatékony lesz. Ennek hatására növelhető volt az LDH kristályossága és a kristályok mérete is. ${ }^{32}$ Nemrégiben kidolgoztak egy módszert, amely kombinálta a mechano-hidrotermális módszert az ultrahangos besugárzással, és így sikeresen állítottak elő fázistiszta, cinkszegény ZnAl-LDH-t. ${ }^{7}$ Mindkét ebben a fejezetben leírt szintézismódszer alkalmas lehet interkalálásra is, de ezekben az esetekben fontos azt megjegyezni, hogy a beépíteni kívánt ligandumnak bizonyos szintig ellenállónak kell lennie a mechanikai behatásokkal szemben.

\subsubsection{Az interkalálás lehetőségei}

Vannak módszerek, amelyekkel sikeresen cserélni lehet a rétegközi térben lévő anionokat. Ezek az interkalálási lehetőségek kihasználják az LDH-k közös tulajdonságait az anioncsere képességet, a memória effektust és a delaminálhatóságot.

\section{Direkt anioncsere}

A módszer alapját az képezi, hogy az anionok különböző erősséggel kötődnek a rétegekhez, így az erősebben kötődők képesek cserélni a gyengébben kötődőket. A fentebb említett, Miyata által publikált liotróp sor ezt az eltérő affinitást fejezi ki. A cserélődés okait a következőkben részletezem.

A termodinamikai okok között az elsődleges az, hogy egy erősebben kötődő anion beépülése energiafelszabadulással jár, és stabilisabb anyag képződik. A felszabadult energia a szolvatációra fordítódik, ami tovább segíti a gyengébben kötődő anion távozását. Összehasonlítva az anioncsere folyamatok egyensúlyi állandóit, azt láthatjuk, hogy az erősebben kötődő anionok beépülését stabilitásnövekedés kíséri. Miyata ez alapján a jelenség alapján állította fel a liotróp sort. Megállapította, hogy a csupasz anion ionsugarának csökkenésével fordított arányban nő az egyensúlyi állandó, ugyanakkor a nagyobb töltéssürüség kedvez a beépülésnek. ${ }^{33}$ Ennek a következménye az, hogy egyértelmüen megállapítható, hogy a kétszeresen (vagy többszörösen) negatív töltésủ anionok erösebben képesek kötödni a rétegekhez. Természetesen ehhez az is hozzájárul, hogy erősebb kötés alakul ki a rétegek és egy többszörösen negatív töltésủ anion között. 
$\mathrm{Az}$ anioncsere során ráadásul növekszik a rendezetlenség is, vagyis az entrópia nő, mivel a nagyobb ionsugárral rendelkező két-, háromszoros töltésủ anionokból kevesebb képes beépülni, mint ahány anion felszabadul és kijut a rétegek közül a folyamat során. Természetesen nemcsak a termodinamika teszi kedvezményezetté a folyamatot, hanem kinetikai oka is van a folyamat előrehaladásának. ${ }^{34}$ A folyamat sebesség-meghatározó lépése ugyanis a beépülő anion diffúziója a rétegek között. Ez a folyamat igen lassú, ha a bejuttatott anion nagyméretü, hiszen az eredetileg kis rétegközi távolsággal rendelkező LDH-ba épül be egy nagy ionsugárral rendelkező anion, amelynek a diffúziója így gátolt a rétegek között. Tehát a beépíteni kívánt anionok „bent ragadnak” a rétegek között.

A liotróp sor alapján a nitrát, klorid és perklorát anionok cserélhetők a legkönnyebben. Ám nemcsak az LDH-ba beépített anionok anyagi minőségével lehet szabályozni a folyamatot. A hőmérséklet, az alkalmazott oldószer vagy gyakrabban oldószerelegy, a pH, az LDH maga, az anionkoncentráció mind befolyásolják a cserét. A hőmérséklet emelésével elősegíthető a rétegközi anionok gyorsabb kilépése a rétegek közül, illetve magasabb hőmérsékleten általában az interkalálni kívánt anionok is jobban oldódnak. Így a hőmérséklet emelése mind kinetikai, mind termodinamikai szempontból segíti az ioncserét. ${ }^{35}$ A nagy ionkoncentráció szintén elősegíti a beépülést, hiszen a nagy (nagyobb) töltésű anionok taszításával szemben, amennyiben megtörténik az ioncsere, kisebb töltésü anionok jutnak oldatba, így csökken a taszítás és a rendszer stabilisabbá válik. Különböző szerves oldószerek alkalmazásával, főleg szerves anionok esetében, ugyancsak elősegíthető az interkalálás. ${ }^{36}$ Ez több okra vezethető vissza. Egyrészt nagyobb mennyiségben oldódnak a szerves komponensek szerves oldószerben, így könnyebb magasabb ionkoncentrációt elérni. Másrészt az oldószerelegy molekulái bejutnak a rétegek közé, hiszen, amint azt már korábban leírtam, nemcsak anionok találhatók a rétegek között, hanem alapesetben víz is, és az interkaláláshoz használt oldószerelegy a szerves vegyület (etanol, aceton, stb.) mellett vizet is tartalmaz. Ez együtt jár a rétegtávolság megnövekedésével, ami elősegíti a nagyobb anionok bejutását. A szerves oldószerek a víztől eltérő pH-ablakuk miatt egyes anionokat képesek magasabb vagy éppen alacsonyabb pH-n stabilizálni. A választott LDH anyagi minősége is fontos, hiszen különböző összetételü rétegek eltérő erősségü kölcsönhatást alakítanak ki az anionokkal, ami befolyásolja a rétegtávolságot, és meghatározza azt is, hogy milyen méretű anionok építhetők be a rendszerbe. Az utolsó, eddig alig érintett befolyásoló tényező pedig a $\mathrm{pH} .{ }^{37}$ Túl alacsony pH nem alkalmazható, mert erösen savas közegben az LDH-k feloldódnak. Korábbi irodalmak alapján a legkisebb $\mathrm{pH}$, amelyen még sikeresen interkaláltak anionokat 
és az LDH szerkezete is megmaradt körülbelül $\mathrm{pH}=4$ volt. Figyelemmel kell lenni az interkalálandó vegyületre is, hiszen annak anionos formáját kell beépítenünk a rétegek közé, amely elég magas pH alkalmazását is szükségessé teheti.

Szervetlen anionokat, polimereket és komplex anionokat $\left(\mathrm{Fe}(\mathrm{CN})_{6}{ }^{2-}, \mathrm{Ag}\left(\mathrm{S}_{2} \mathrm{O}_{3}\right)_{2}{ }^{3-}\right)$ is sikerrel építettek már be ezzel a módszerrel. ${ }^{38,39}$ A direkt anioncserének ugyanakkor vannak korlátai is. Nem építhetők be olyan anionok, amelyek mérete jelentősen eltér a prekurzorban található ion méretétől. A beépíteni kívánt ion nem léphet reakcióba sem az LDH-t felépítő fém ionokkal, sem pedig a cserélni kívánt anionokkal. Valamint azt is biztosítani kell, hogy a beépülés nagyobb energianyereséggel járjon, mint a szolvatáció.

\section{Dehidratáció-rehidratáció}

A módszer elvi alapját a memória effektus képzi. Amennyiben egy LDH-t megfelelő hőmérsékleten kezelünk (CaAl-LDH esetében például maximum $550{ }^{\circ} \mathrm{C}$-on) az $\mathrm{LDH}$ szerkezete összeomlik, de a keverékoxidból még visszanyerhető az eredeti szerkezet vizes (oldószeres) kezelés hatására. Ez a rehidratáció. ${ }^{40}$ Amennyiben a rehidratáció során nem csak oldószer, hanem egy interakalálni kívánt anion is található az oldatban, akkor annak beépülése nagy valószínüséggel meg fog történni. A folyamat során elengedhetetlen, hogy inert atmoszférát alkalmazzunk, máskülönben a légköri szén-dioxid beoldódása miatt karbonát ion épül be a rétegek közé. ${ }^{5}$

Korábban egészen nagyméretű anionokat (pl. gyógyszermolekulák anionjait) építettek be a módszer segítségével. ${ }^{41}$ Természetesen problémák itt is felléphetnek az interkalálás során. Szerves oldószerek alkalmazása nem elönyös a rétegek visszaépülése szempontjából, így azok az anionok, amelyek csak szerves közegben építhetők be, ezzel a módszerrel nem interkalálhatók. Az LDO-k (layered double oxide - a szakirodalom szóhasználata azokra az oxidkeverékekre, amelyek LDH-ból keletkeztek és még rehidratálhatók) sokkal reaktívabbak a prekurzor LDH-nál, így könnyebben lejátszódhatnak az interkalálandó és az LDO között redoxi, illetve komplexképzési reakciók.

\section{Delamináció, majd a réteges szerkezet újraépitése}

A folyamat lényege az, hogy bizonyos oldószerek hatására az LDH-k rétegről rétegre szétbonthatók, és oldatfázisban monoréteges LDH szuszpenziók alakulhatnak ki. A klasszikus delaminálószerek a DMF, a DMSO és az $N$-metil-pirrolidon, de a prekurzor LDH rétegtávolságától függően alkoholok, de akár a víz is képes lehet delaminálni. ${ }^{42,43}$ 
Ezek az oldószerek úgy fejtik ki a hatásukat, hogy a rétegek közé bejutva elektrosztatikus kölcsönhatásba lépnek a rétegekkel, így a rétegtávolság megnövekszik, és végül akkora lesz, hogy a rétegeket már nem tudják egyben tartani az ionos kölcsönhatások. Az oldószer eltávolítása után a rétegek visszarendeződnek, de szinte sosem nyerik vissza pontosan ugyanazt a szerkezetet.

A folyamat interkalálásra is használható, méghozzá kétféleképpen. Egyrészt az interkalálandó ion feloldható a delamináló oldószerben, és a réteges szerkezet (részleges) visszaalakulása során beépülhet a rétegek közé. Ez a megoldás a kevésbé hatékony, mivel amennyiben eltávolítjuk az oldószert, úgy azzal a benne oldott anionok jelentős részét is eltávolítjuk, így csupán a rétegek közvetlen közelében elhelyezkedő, a rétegekkel elektrosztatikus kölcsönhatást létesítő anionok épülhetnek be. Ráadásul a folyamat nagyon érzékeny a szennyezésekre.

A másik módszer során első lépésben tenzid molekulákat építenek be a rétegek közé, ezzel megnövelve a rétegtávolságot. ${ }^{44}$ Ezt követi egy direkt anioncsere, amely során nagyméretü anionok könnyebben beépíthetőek. Habár számos alkalommal alkalmazták már ezt az eljárást különböző anionok beépítésére, a rossz szabályozhatósága és reprodukálhatatlansága miatt nem igazán használható rutinszerüen.

\subsection{Heterogén katalizátorok}

A heterogén katalízis definíciószerüen azt jelenti, hogy a katalizátor, ami meggyorsítja egy reakció lejátszódását, azáltal, hogy új reakció utakat nyit meg, ugyanakkor a reakció végén változatlan formában visszanyerhető, másik fázisban található, mint a reaktánsok. A heterogén katalízis lépései a következő ${ }^{45}$ :

- $\quad$ a reaktánsok diffúziója a katalizátor felülethez,

- a reaktánsok adszorpciója (kemiszorpciója),

- felületi diffúzió,

- $\quad$ a termék(ek) kialakulása,

- $\quad$ felületi diffúzió

- a termékek deszorpciója,

- $\quad$ a termékek eltávolodása a katalizátor felülettől (diffúzió útján).

A katalizátorok úgy fejtik ki a hatásukat, hogy bizonyos kötések felbomlását, valamint más kötések kialakulását elösegítik. Ez a folyamat a heterogén katalitikus rendszerek esetében kétfajta mechanizmussal írható le. Az egyik a Langmuir-Hinshelwood 
mechanizmus, amely úgy írja le a folyamatot, mint két reaktáns reakcióját a katalizátor felületén. A másik az Eley-Rideal mechanizmus, amelynek során csak az egyik rektáns kötődik meg a felületen, a másik a gázfázisból érkezve lép reakcióba a kemiszorbeált felületi alakulattal.

A heterogén és homogén katalizátorok összehasonlításából azonnal kiderül, hogy az ipari kutatások miért fókuszálnak inkább a heterogén katalizátorokra ${ }^{46}$.

A heterogén katalizátorok előnyei:

- sokkal nagyobb a termikus és pH-stabilitásuk,

- sokkal könnyebben alkalmazhatóak áramlásos rendszerben,

- könnyebben visszanyerhetők, regenerálhatók és újrafelhasználhatók,

- viszonylag ellenállók a katalizátomérgekkel szemben.

Ugyanakkor a homogén katalizátorok általában nagyobb aktivitásúak és, föként jóval szelektívebbek, mint a heterogén katalizátorok. Visszanyerésük és újrafelhasználhatóságuk azonban nehéz, ha egyáltalán megvalósítható.

A két katalizátortípus elönyös tulajdonságai azonban ötvözhetők a homogén komplexek heterogenizálásával. Mivel kísérleti munkánk során ilyen anyagokat készítettünk és teszteltünk kölünféle reakciókban, ezért a további tárgyalást erre a heterogén katalizátortípusra korlátozzuk.

\subsubsection{Homogén katalizátorok heterogenizálása}

A fentebb leírt okokból érdemes a homogén fázisban jól működő katalizátorokat szilárd hordozó felületén, vagy annak rétegei között megkötni. Kézenfekvő azonban az a problémafelvetés, hogy ebben az esetben, ha más nem is változik, a katalizátorok szelektivitása csökken az aktív centrumok rosszabb hozzáférhetősége miatt. Ugyanakkor a későbbiekben jó néhány példát fogunk leírni, amikor a körülmények optimalizálásával elérhető lett legalább ugyanaz az aktivitás és szelektivitás, mint homogén fázisban, és a visszanyerhetőség sokkal jobb volt.

A heterogenizált katalizátorokat sokféleképpen lehet csoportosítani, de az egyik legkézenfekvőbb módja ennek a hordozó és az aktív komponens között kialakuló kölcsönhatás alapján történhet. Ezek alapján megkülönböztethetünk ${ }^{45-47}$ :

- adszorpcióval,

- ionos kölcsönhatással,

- kovalens kötéssel, 
- keresztkötéssel (enzimek esetében)

- abszorpcióval megkötött katalizátorokat.

A heterogenizált fémkomplexek alkalmazása már elterjedőben van, jó néhány alkalommal alkalmazták már őket redoxi folyamatokban, kapcsolási reakciókban és más szerves kémiai átalakításokban. ${ }^{48}$ A következőkben néhány példát hozunk fel az alkalmazási lehetőségeikre.

A különféle kapcsolási reakciókban Pd-komplexeket alkalmaznak a legtöbb esetben katalizátorként. Ugyanakkor a 2000-es évek elejétől nagyszámú irodalom lelhető fel heterogenizált palládium-katalizátorok alkalmazásával kapcsolatosan. Az ilyen hordozós katalizátorkat a Heck-reakció példáján mutatjuk be. Az első sikeresnek mondható kísérletekről szóló közlemény azt írta le, hogy $\mathrm{Pd}$-ot adszorbeáltak $\mathrm{MgO}$, valamint csontszén felületére, és így tanulmányozták katalizátorként való alkalmazhatóságukat. ${ }^{49}$ Megállapították, hogy a MgO-hordozós katalizátor aktivitása nagyobb volt a csontszénhordozós katalizátorénál, és összevethető volt a homogén katalizátorok aktivitásával. A hordozós katalizátorok aktivitása közötti eltéréseket a hordozók elektrondonálási képességeivel magyarázták.

A későbbiekben ionos jellegü kölcsönhatásokkal kötöttek meg Pd-komplexeket hordozókban. Több publikáció született különféle zeolitokba történő beépítéssel kapcsolatosan. NaY-zeolitba a $\left[\mathrm{Pd}\left(\mathrm{NH}_{3}\right)_{4}{ }^{2+}\right]$ kationos komplexet építették be ioncsere segítségével, és az így kialakított kompozitot alkalmazták klóracetofenon és sztirol reakciójában. ${ }^{50} \mathrm{~A}$ zeolitba történő beépítés hatására megnövekedett konverziókat tapasztaltak a korábbi irodalmi eredményekhez képest, és ez még akkor is pozitívum volt, ha ehhez magasabb hőmérsékletet kellett biztosítaniuk. Azonban nemcsak zeolitokba építettek be sikeresen aktív Pd-komponenst. A montmorillonitba beépített komplex közepes aktivitást mutatott 4-klórbenzaldehid és sztirol közötti kapcsolási reakcióban. ${ }^{51}$ Ugyanakkor sikeresen interkaláltak ZnAl-LDH-ba anionos Pd-komplexet, $\left[\mathrm{PdCl}_{4}\right]^{2-}$-ot. ${ }^{52}$ Azt figyelték meg, hogy a klór-benzol és metil-akrilát közötti kapcsolási reakciót is képes volt elősegíteni ez a katalizátor, nem csupán a reaktívabb bróm-benzollal végrehajtott kapcsolást.

Nemrégiben kovalens kötéssel is rögzítettek Pd-klorokomplexet módosított szilikagél felületére. A hordozó felületét acetil-acetonnal módosították, és a módosítón található oxocsoportok kötötték meg a Pd-komplexet. Ezen a katalizátoron azonban egyelöre nem hajtottak végre sikeres kapcsolási reakciót. ${ }^{53}$ Hasonlóképpen igyekeztek Pd-komplexeket 
rögzíteni különbözö hordozók felületén azért, hogy a Suzuki-Miyaura kapcsolás során használják fel őket. ${ }^{54-56}$

Redoxi reakciók elősegítésére egészen más jellegü heterogenizált katalizátorokat alkalmaztak. Jó aktivitással és szelektivitással használtak fel átmenetifém-tartalmú rögzített katalizátorokat ilyen típusú reakciókban. $\mathrm{Cu}(\mathrm{II})$-komplexeket kötöttek meg például szilikagél illetve poli(4-vinilpiridin) felületén, majd alkalmazták őket különböző redoxi reakciókban. A fenol oxidációjában a szerves polimeren rögzített $\mathrm{Cu}(\mathrm{II})$-komplex 56\%-os konverziót mutatott. ${ }^{57}$ A szervetlen hordozós minta pedig az alkének oxidációjában mutatott hasonló aktivitást. ${ }^{58}$

Zeolitokban ionosan rögzített $\mathrm{Cu}(\mathrm{II})$-, és $\mathrm{Co}(\mathrm{II})$-komplexeket is találunk nagy számban az irodalomban, amelyek a legtöbb esetben az átmenetifémeknek aminosavakkal képzett komplexeit jelentik. ${ }^{59-61}$ A fent leírt kompozitok kiemelkedő aktivitással, és elfogadható szelektivitással voltak képesek katalizálni a fenol, valamint az alkoholok oxidációját. Ebben az esetben is építettek be anionos komplexeket LDH-k rétegei közé. $[\mathrm{Cu}(\mathrm{II})-\mathrm{Nitrilotriacetát}]^{-}$-ot és [Ni(II)-nitrilotriacetát $]^{-}$-ot építettek be $\mathrm{ZnCr}-\mathrm{LDH}$-ba direkt anioncsere segítségével, méghozzá úgy, hogy a komplexet első lépésként oldatban szintetizálták. ${ }^{62} \mathrm{Fe}(\mathrm{III})$-porfirin és $\mathrm{Cu}(\mathrm{II})$-komplexeket is építettek ki ZnAl-LDH rétegei között, ezekröl azonban egy későbbi fejezetben írunk. ${ }^{63,64}$ Ami közös volt ezekben a kompzitokban az az, hogy jó epoxidszelektivitással voltak képesek az alkének és alkoholok oxidációjára ( $\sim 80 \%)$, ugyanakkor az aktivitásuk alig érte el az elfogadható szintet ( 20\%).

Természetesen megtörtént a különböző komplexek kovalens rögzítése is. Például átmentifém ionoknak (Fe(III), $\mathrm{Cu}(\mathrm{II}), \mathrm{Ni}(\mathrm{II})$ stb.) aminosavakkal (L-hisztidin, L-cisztein stb.) képzett, úgynevezett bioinspirált komplexeinek rögzítése módosított szilikagél felületén és különféle gyantákon is. ${ }^{65-67} \mathrm{Az}$ összes ilyen esetben sikerült aktivitásnövekedést elérni az egyéb módszerekkel rögzített komplexekkel tapasztaltakhoz képest, és a szelektivitásértékek is elfogadhatók voltak.

Heterogenizált katalizátorokat alkalmaztak már korábban is alkoholok dehidrogénezésére, hidrogén-peroxid bontására, valamint szuperoxid gyökök dizmutálására is. ${ }^{68-70}$

\subsubsection{Heterogén katalitikus reakciók}

Ebben a fejezetben arra a három reakcióra koncentrálunk, amelyek szerepeltek munkánk során modellreakcióként, és azokra a fém ionokra, amelyek rögzített komplexeit elkészítettük, és felhasználtuk a reakciók katalizátoraiként. 


\section{A ciklohexén oxidációja}

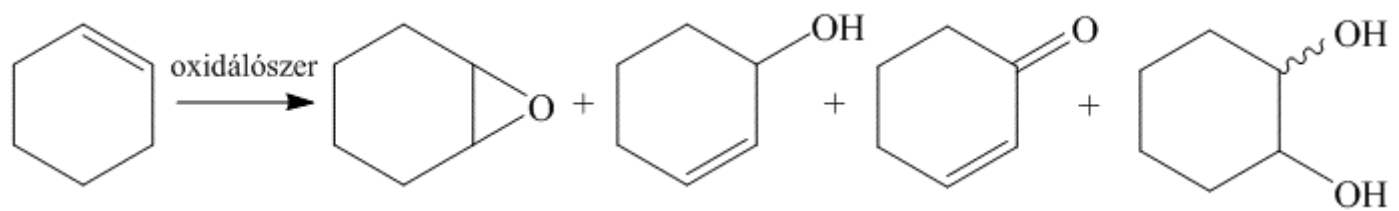

1. séma A ciklohexén oxidációja.

A ciklohexén oxidációja során a vegyipar számára fontos termék, a ciklohexén-oxid keletkezik, amelyet felhasználnak alapanyagként a kozmetikai iparban, az élelmiszeriparban, valamint agrokémiai termékek szintézise során is. ${ }^{71-73}$

A hidrogén-peroxid, szerves peroxidok vagy akár a levegő oxigénje is képes lehet oxidálni az alkéneket, megfelelő katalizátorok alkalmazásával. ${ }^{74} \mathrm{~A}$ legtöbb alkén oxidációja katalizátor nélkül is végbemegy, de nagyon gyenge hozamok és rossz szelektivitás jellemzi ezeket a folyamatokat. Kivételt képeznek a terc-butil-hidroperoxid (TBHP) alkalmazásával lejátszatott reakciók, amelyek katalizátor hozzáadása nélkül is epoxidszelektívek, ám ehhez magas hőmérsékletre és hosszú reakcióidőre van szükség. ${ }^{75-77}$

Sok esetben alkalmaztak hordozóra rögzített átmenetifém komplexeket ezekben az oxidációs folyamatokban. Ezek közül a továbbiakban kiemeljük a legfontosabbakat. A $\mathrm{Cu}(\mathrm{II})$-tartalmú rendszerek leírásával kezdjük, mivel talán ennek a legnagyobb az irodalma. Alkalmaztak polimer felületén adszorbeált $\mathrm{Cu}(\mathrm{II})$-Schiff bázis komplexeket, mint aktív és újrafelhasználható katalizátorokat. Azt találták, hogy $50{ }^{\circ} \mathrm{C}$ és 7 óra reakció idő, valamint TBHP alkalmazása mellett gyenge konverziókkal ugyan, de lejátszódik a folyamat. Ugyanakkor nagymértékü szelektivitásnövekedést értek el, ráadásul az oldószer megválasztásával befolyásolni is tudták a szelektivitást. Vízben, acetonitrilben és tetrahidrofuránban ketonszelektivitás mutatkozott, de diklór-metán alkalmazásával el lehetett érni azt, hogy a folyamat epoxidszelektív legyen. ${ }^{78}$

$\mathrm{Cu}$ (II)-komplexek Y-FAU zeolitba építésével nem sikerült jelentős változást elérniük, összehasonlítva a felületen megkötött rézkomplexszel. ${ }^{79-81}$ Építettek be 1-(2piridilazo)-2-naftol valamint hisztidinát ligandum alkalmazása mellett is rézionokat a zeolit nagyüregeibe, de nem sikerült epoxidszelektivitást elérni, sőt a naftolszármazékkal képzett komplex esetében azt figyelték meg, hogy egy lassan átalakuló köztitermék irányába ment el a reakció, ez pedig a 1-terc-butil-peroxi-2-ciklohexén volt.

Ni(II)-komplexek felhasználására sokkal kevesebb példa található az irodalomban. A naftolszármazékkal képzett komplexéről ír a fentebb már említett cikk, de ugyanolyan 
eredményt kapták a nikkelkomplexek esetében is, mint amit a réztartalmú komplexeknél megfigyeltek. ${ }^{80}$ MCM-41 hordozó alkalmazása mellett használták Ni(II) makrociklus ligandummal képzett komplexét. Azt találták, hogy TBHP-t alkalmazva kloroformban $100 \%$-os epoxid szelektivitás érhető el, de a konverzió csupán $8 \%$ volt. $^{82}$

Fe(III) ion alkalmazására nem találtunk példát. Ez vélhetően azzal magyarázható, hogy a kevés korábbi irodalom leírja, hogy a vastartalmú komplexek leginkább 2ciklohexén-1-on vagy 2-ciklohexén-1-ol képződésére szelektívek. ${ }^{83}$

A mangántartalmú rendszerek ezzel ellentétben nagy népszerüségnek örvendenek. Három különböző munkában sikeresen értek el minden fontosabb elérhető célt, de ezeket sajnos nem tudták kombinálni. Ugyanis (az eddig leírt irodalmakhoz képest) viszonylag magas konverziót értek el Mn(II)-imidazol komplexekkel, amelyek funkcionalizált szilikagél felületére voltak kötve. ${ }^{84}$ Ez a rendszer azonban csak 70\%-os epoxidszelektivitást mutatott. Mn(II)-pirazolilpiridin komplexet mezopórusos SBA-15-be építve ugyanakkor 99\%-os konverziót és 96\% szelektivitást tudtak felmutatni, de ebben az esetben az újrafelhasználás nem müködött. ${ }^{85}\left[\mathrm{Mn}(\mathrm{II})(\mathrm{fenil})_{2}\right]\left(\mathrm{CF}_{3} \mathrm{SO}_{3}\right)_{2}$ komplexet beépítve a fent leírt zeolitba a szelektivitást 100\%-ra növelték, és a katalizátor is visszanyerhetővé vált, azonban a konverzió jelentősen visszaesett. ${ }^{86}$

Szándékosan a végére hagytuk munkánk előképét. A csoportban korábban kialakítottak funkcionalizált szilikagél felületén aminosav komplexeket, amelyek elfogadható konverzióval és magas epoxidszelektivitással katalizálták a folyamatot, mindezt enyhe körülmények között. Ráadásul azt találták, hogy az aktivitás és a szelektivitás is nagymértékben független volt mind az aktív centrumban megtalálható fémion anyagi minőségétől $(\mathrm{Mn}(\mathrm{II}), \mathrm{Cu}(\mathrm{II}), \mathrm{Ni}(\mathrm{II}), \mathrm{Fe}(\mathrm{III}))$, mind pedig a komplexben résztvevő aminosav ligandumok anyagi minőségétől (hisztidin, tirozin, cisztein, cisztin). ${ }^{87-}$ 90

Allil-alkohol epoxidációja

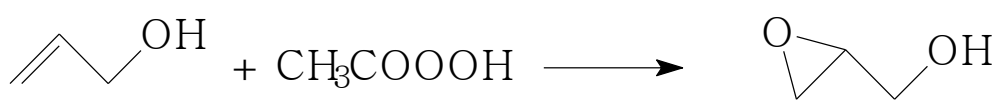

2. séma Az allil-alkohol epoxidációja.

Az allil-alkoholok epoxidációja egy régóta ismert reakció, hiszen már az 1920-as évekből származik publikáció, ami ciklusos allil-alkoholok epoxidációjáról számolt be, 
illetve ezen a publikáción alapszik egy amerikai szabadalom is. ${ }^{91,92}$ Az allil-alkohol epoxidációja két úton is végbemehet. Egyrészt hő hatására intramolekulárisan átrendeződhet, és propilén-oxidot kapunk termékként. Ez egy optikailag aktív termék, és az átrendeződés eredményeként racém elegyet kapunk. A folyamat erős, nem nukleofil bázisokkal (pl. butil-lítium) katalizálható. ${ }^{93}$

A másik út, ami az ipar számára fontosabb, a kettős kötés epoxidációja, amikor glicidol képződik, ami egy fontos szerves kémiai alapanyag. ${ }^{94}$ A folyamat katalizátor nélkül is lejátszódik, de nagyon rossz hozammal, ugyanis enon képződésére is van lehetőség. A glicidol is egy optikailag aktív vegyület. A homogén fázisú reakcióban racemát képződik, és ez történik akkor is, ha az akár homogén, akár heterogén katalizátor nem tartalmaz optikailag aktív komponenst. ${ }^{95}$

Az alkének epoxidációjára általánosan használt perkarbonsavak (mint például a legtöbbet használt perecetsav) ugyan alkalmazhatók az allil-alkohol epoxidációja során, de a hozamok alacsonyak. Volfrám- vagy molibdénsav hozzáadásával azonban el lehetett érni azt, hogy a reakció jó termeléssel menjen végbe. ${ }^{96,97}$ Nyilvánvaló, hogy ezekben az esetekben ezek a savak voltak a katalizátorok. Ugyanakkor ezek között a körülmények között kemoszelektivitás megfigyelhető volt ugyan, hiszen az enon forma nem képződött, de a folyamat nem volt sem régio-, sem sztereoszelektív.

Oxidálószerként kiválóan használhatók a különféle szervetlen és szerves peroxidok is. A szervetlen peroxidok alkalmazása esetén szintén szükség van a fentebb leírt katalizátorok valamelyikére. Sokáig ezekkel az oxidálószerekkel és katalizátorokkal is csupán kemoszelektivitást sikerült elérni, igaz jóval magasabb hozamok mellett. ${ }^{98}$ Ugyanakkor nemrégiben leírták, hogy perecetsav alkalmazásával nagyon magas hozamokat sikerült elérni ( $99 \%)$, ráadásul ebben az esetben sikerült kemo- és régiószelektivitást is megfigyelni. ${ }^{99}$ A cikk érdekessége az is, hogy vizes közeget alkalmaztak, továbbá az is, hogy felületaktív amfolitikus szénhidrátokat adtak adalékanyagként a rendszerhez.

Szerves peroxidok alkalmazásával viszont sikerült enantioszelektív szintézisutat találni. Ehhez persze megfelelő katalizátorra és adalékanyagokra volt szükség. Sharpless és munkatársai kifejlesztették a titán-tetraizopropoxidot (TTIP), amely enantioszelektív katalizátorként viselkedett. ${ }^{100} \mathrm{Az}$ oxidálószer TBHP volt, valamint adalékanyagként $S$ konfiguráció eléréséhez $(S, S)$-dietiltartarátot, $R$ konfiguráció eléréséhez $(R, R)$-dietiltartarátot alkalmaztak. 
Titán-, volfrám- és molibdéntartalmú katalizátorokon kívül, alkalmaztak korábban vegyértékváltó átmenetifém ionokat is (vas, mangán, réz és nikkel). ${ }^{101-103}$ A legtöbb esetben szubsztituálták a polioxometallát-katalizátorokat. Habár a katalizátorok aktív maradt, de aktivitása csökkent, valamint nem sikerült javítani a szelektivitásértékeken sem. Mn(II)-szalén és Fe(III)-porfirin komplexeket sikerrel alkalmaztak aktív és visszanyerhető katalizátorként, és a mangánkomplex esetében egészen magas (94\%-os) diasztereoszelektivitást detektáltak. ${ }^{104}$ Természetesen születtek publikációk, amelyek polioxometallátok heterogén katalizátorként való felhasználásáról számoltak be. Ehhez zeolitokba, illetve LDH-k rétegei közé juttatták be az aktív komponenst. ${ }^{105,106}$ A munkák célja a szelektivitás növelése lett volna, ezt azonban nem sikerült elérni, habár mindkét esetben sikeresen állítottak elő többször felhasználható és könnyen kezelhető heterogén katalizátorokat.

\section{Ullmann-típusú diaril-éter-szintézis}

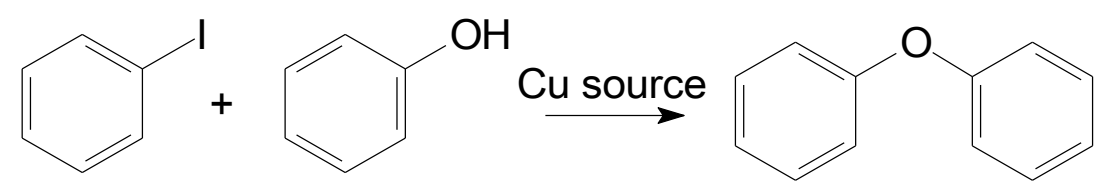

3. séma Az Ullmann-típusú diaril-éter szintézis.

A diaril-éter szintézisek 100 éve ismert módja az Ullmann-típusú éterképzés. A reakció katalitikus úton játszódik le hozzáadott bázis jelenlétében. ${ }^{107} \mathrm{Az}$ irodalomban korábban leginkább réz- és palládiumtartalmú katalizátorokat alkalmaztak, ugyanakkor nem volt ritka, hogy a Fe(III) volt az aktív komponens. Sokféle felhasználási módja van az Ullmann-kapcsolások termékeinek az iparban, mind a gyógyszergyártás (pl.: Vankomicin gyártás) mind a finom kemikáliák gyártása során. ${ }^{108,109}$

Sokáig a különféle Ullmann-kapcsolások nem voltak elterjedtek, mivel magas forráspontú poláris oldószerekben, mint az $N$-metil-pirrolidon, DMF vagy a nitrobenzol, és magas hőmérsékleten (gyakran $\sim 210^{\circ} \mathrm{C}$ körül) mentek elfogadható sebességgel a folyamatok, sztöchiometrikus mennyiségű rézsó alkalmazása mellett. ${ }^{110}$ Később Pdkatalizátorok alkalmazásával sikerült kevésbé reaktív közegben végrehajtani a reakciót, de ez igen költséges eljárásnak bizonyult. ${ }^{111}$ A 2000-es évek elején katalitikus mennyiségben alkalmaztak réztartalmú komponenst, és sikerült enyhe körülmények között $\left(90-110{ }^{\circ} \mathrm{C}\right)$ magas termeléssel lejátszatni a folyamatot. Az azóta eltelt időben nagyszámú publikáció született, amelyekben leírták a különböző ligandumok hatását, optimalizálták a 
reakciókörülményeket, és vizsgálták az enantio- és diasztereoszelektivitásokat. Ezek közül emelünk ki néhányat, amelyek legalább részben kapcsolódnak az értekezés témájához.

Először 1995-ben alkalmaztak sikeresen réztartalmú katalizátorokat elfogadható termeléssel. ${ }^{112}$ Vizes közegben sikerült lejátszatni $o$-klór-benzolnak fenollal történő Ullmann-kapcsolását. Azt állapították meg, hogy fontos hatással van a reakcióra az alkalmazott bázis anyagi minősége, mivel $\mathrm{K}_{2} \mathrm{CO}_{3}$ alkalmazása mellett maximum 37\%-os termelést tudtak megvalósítani, ezzel szemben piridint alkalmazva 57\%-os konverziót is tapasztaltak 2-karboxi-difenil-éterre nézve. A folyamat során $\mathrm{Cu} / \mathrm{CuI}$-ot használtak katalizátorként, és homogén fázisban zajlott le a reakció. Azt már korábban megállapították, hogy az orto helyzetü halogenidek a $\mathrm{F}^{-}<<\mathrm{Cl}^{-}<\mathrm{Br}^{-}<\mathrm{I}^{-}$sorrendben képesek aktiválni a benzolgyürüt. Ez természetesen a katalitikus Ullmann-kapcsolásokra is igaznak bizonyult, és ezt a hatást a kialakuló átmeneti komplex stabilitásának tulajdonították. $^{113}$

Ezt a receptet többször is módosították és megállapították, hogy például ultrahangos besugárzással növelhetők a hozamok. 30 perces, 20 kHz-es besugárzással 84\%-os hozamot tudtak elérni. ${ }^{114}$ Az igazi áttörés 1997-ben következett be, amikor réz-triflátot $\left(\mathrm{Cu}(\mathrm{OTf})_{2}\right)$ használtak rézforrásként. ${ }^{115}$ A munka során ráadásul nemcsak új ligandumot, de újszerü bázist is alkalmaztak, mégpedig a $\mathrm{Cs}_{2} \mathrm{CO}_{3}$-t. Ilyen reakciókörülmények között már használhattak toluol oldószert a DMF helyett. Így csupán $110^{\circ} \mathrm{C}$-t kellett alkalmazni ahhoz, hogy magas hozamokat (> 80\%) érjenek el a legkülönfélébb szubsztituált reaktánsok esetében is. A ligandumok hatását már ezt a cikket megelőzően is vizsgálták, és azt tapasztalták, hogy minél kevésbé akadályozza az átmeneti komplex képződését a ligandum, annál magasabbak voltak a konverziók. ${ }^{116}$ Piridin, valamint piridinhez hasonló ligandumok esetében megvizsgálták a mono-, bi-, és tridentát ligandumok hatását, és az eredményekből az derült ki, hogy bidentát ligandumok segítették leginkább elő a konverziók növekedését. ${ }^{117}$ A későbbiekben bebizonyosodott, hogy aminosav ligandumok stabilizálják az átmeneti komplexet, és így segítik elő a folyamatot. ${ }^{118}$

Egy tanulmányban azt is leírták, hogy rézforrás esetében is előnyös CuI-ot használni, mert a többi halogenidsó alkalmazásával összehasonlítva ez előnyösen befolyásolja a konverziókat. Egy 2008-as publikációban, azt is leírták, hogy ligandumok és hozzáadott segédanyagok nélkül is el lehetett érni 95\%-os termelést DMF alkalmazásával, a visszafolyatás hőmérsékletén. ${ }^{119}$ Ezt úgy sikerült elérniük, hogy fázistranszfer katalízist alkalmaztak, vagyis tetrabutil-ammónium-kloridot $\left(\mathrm{Bu}_{4} \mathrm{NCl}-\mathrm{t}\right)$ adtak a rendszerhez, így a rézforrásként alkalmazott CuI oldódását segítették, valamint stabilizálták az átmeneti 
komplexet. Ez a közlemény arra is rámutatott, hogy nagyon jól alkalmazható bázis a $\mathrm{Cs}_{2} \mathrm{CO}_{3}$, de nem minden esetben ez az optimális választás; ebben az esetben például $\mathrm{K}_{3} \mathrm{PO}_{4}$-t alkalmaztak.

Homogén katalizátorok esetében is alkalmaztak $\mathrm{Cu}$ (II)-sókat, de ezek aktivitása minden esetben elmaradt a $\mathrm{Cu}(\mathrm{I})$-sók esetén tapasztaltaktól. ${ }^{120}$ Ugyanakkor heterogenizálva a katalizátorokat módosított szilikagél felületén azt állapították meg, hogy a $\mathrm{Cu}$ (II)-tartalmú katalizátorok bizonyultak aktívabbnak, és akár 92\%-os konverziót is el lehetett érni, amennyiben oldószerként DMF-t és KF bázist használtak. ${ }^{121}$ Ez a tanulmány is jól példázza, hogy minden rendszerre optimalizálni kell a körülményeket, hiszen csupán 51\%-os konverziót tapasztaltak $\mathrm{Cs}_{2} \mathrm{CO}_{3}$ alkalmazása mellett.

Nem csupán réz- és palládiumtartalmú katalizátorokat alkalmaztak az Ullmanntípusú éterképzésekben, hanem Fe(III)-tartalmú anyagokat is. ${ }^{122}$ Hasonló eredményre jutottak, mint a réztartalmú rendszerek esetében. Az optimális paraméterek a következők voltak: $\mathrm{FeCl}_{3}, \mathrm{DMF}, \mathrm{Cs}_{2} \mathrm{CO}_{3}$, bidentát ligandumok, $135^{\circ} \mathrm{C}$ és 20 óra reakció idő. Ezek a paraméterek a reaktánsok széles körében alkalmazhatók, és jó hozamok (78-99\%) érhetök el. Ugyanakkor nem találtunk az irodalomban példát arra, hogy heterogén vastartalmú katalizátorokat alkalmaztak volna erre a reakciótípusra.

\subsection{Komplex anionok beépítése réteges kettős hidroxidokba}

Ebben a fejezetben részletesen bemutatjuk, hogy milyen eredmények születtek a korábbiakban átmenetifém komplexek $(\mathrm{Mn}, \mathrm{Fe}, \mathrm{Cu}, \mathrm{Ni})$ interkalálására réteges kettős hidroxidokba. Amennyiben az adott komplexnek katalitikus aktivitása is volt, arra külön kitérünk.

\section{Mangántartalmú komplexek interkalációja}

Sokféle mangántartalmú komplexet interkaláltak már sikerrel valamilyen LDH rétegei közé. Az 1999-ig született munkákat egy összefoglaló cikk részletesen leírja; az ebben található publikációkkal fogjuk minden esetben kezdeni az adott részek kifejtését. ${ }^{123}$

Az összefoglaló cikkben többszörösen összetett komplexek beépítéséről számolt be több esetben is a szerző, így kloro(mezo-tetra-4-(szulfonátofenil)-porfirináto-Mn(III) valamint egy szubsztituált Keggin-ion származékot $\left(\left[\mathrm{SiW}_{11} \mathrm{O}_{39} \mathrm{Mn}\left(\mathrm{H}_{2} \mathrm{O}\right)\right]^{6-}\right)$ is beépítettek réteges kettős hidroxidokba. ${ }^{124,125}$ A két anionban az a közös, hogy a dehidratációrehidratáció mechanizmusát használták a beépítés során, valamint mindkét esetben $\mathrm{MgAl}$ LDH volt a gazda vegyület. A Keggin-ion beépítése során, egészen biztosan a rétegek közé épült be az anion, mivel az XRD mérések azt mutatták, hogy a rétegtávolság 10 Å-ről 
15,2 Å-re nőtt. Továbbá mangántartalmú polioxometallátokat (POM) is sikerrel interkaláltak, de ebben az esetben már a direkt anioncsere módszerét alkalmazták. A beépített bioinspirált fémkomplexek magas aktivitást ( 80\%), ugyanakkor epoxidra nézve nagyon rossz szelektivitást mutattak a ciklohexén oxidációja során. ${ }^{126}$

Egy későbbi publikáció arról is beszámolt, hogy a Mn(III)-porfirinszármazékkal interkalált LDH-nak (1. ábra) katalitikus aktivitása is lehet. Beszámoltak arról, hogy ZnAlLDH-ba beépítve az aktív centrumot, a kompozit elfogadható konverziókkal ( 40\%) és nagyon magas epoxid szelektivitásokkal ( 90\%) képes volt katalizálni különbözőféle nyíltláncú és gyürüs alkének, valamint allil-alkoholok oxidációját. ${ }^{127}$ Ezek az értékek, összehasonlítva a porfirinszármazékok oldatfázisú katalitikus felhasználásával, magasnak számítanak. A legnagyobb elönye a rögzített komplexeknek az, hogy négyszeri felhasználásuk esetén sem vesztették el aktivitásukat, szemben a homogén változatukkal.

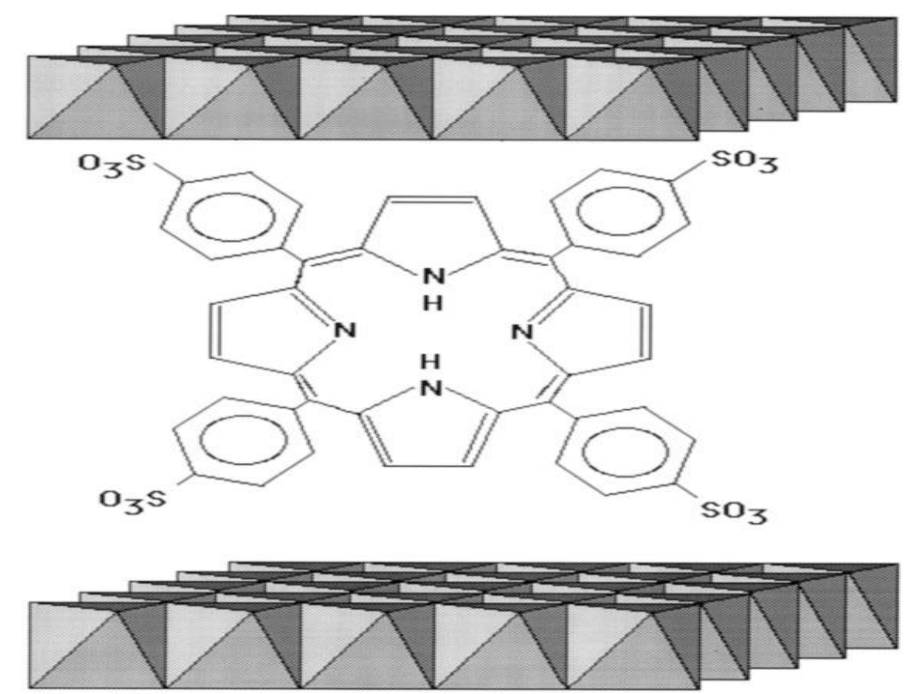

1. ábra: MgAl-LDH-ba interkalált porfirinszármazék sematikus ábrázolása. ${ }^{127}$

Az összefoglaló cikk megírása óta eltelt időszakban, azt mondhatjuk, hogy rutin eljárássá vált $\mathrm{Mn}(\mathrm{III})$-szulfonáto-szalén komplexeket beépíteni ZnAl-LDH rétegei közé. ${ }^{128-}$ 133 A szalénkomplexek már régóta ismertek az irodalomban, a Schiff-bázis ligandumok közé tartoznak. Két imino- és két hidroxilcsoportot tartalmaznak, amelyek potenciálisan négy kötőhelyet jelentenek a hard sajátságú fém ionok számára. A szulfonálásukra, pedig azért van szükség, hogy vízoldhatóvá tegyék őket. A legtöbb átmenetifém ion szalénkomplexe ismert, és ezeket gyakorta használják biomimetikus katalizátorokként, redoxi folyamatokban. A beépített komplexet is oxidációs reakciókban alkalmazták, egészen pontosan különböző prokirális olefinek epoxidációjára. Az epoxidáció különlegessége az volt, hogy a folyamathoz elegendő volt oxidálószerként oxigént 
használni, de az egyik publikáció szerintn a levegő oxigénje is megfelelő volt. Ez is azt mutatja, hogy sikerült aktív katalizátorokat elöállítani. $R$-(+)-limonén esetében $100 \%$-os konverzióról és 90\% fölötti szelektivitásról (kemoszelektivitásról) számoltak be limonén1,2-epoxidra nézve. ${ }^{130} \mathrm{~A}$ rendszer bizonyos fokú diasztereoszelektivitással is bírt, hiszen elfogadható, 54\%-os diaszteromer többletet detektáltak (+)-cisz-limonén-1,2-epoxidra. Továbbá sikerült nem vízoldható szalénkomplexet is beépíteni MgAl-LDH rétegei közé. Ezek stabilis, újra felhasználható katalizátoroknak bizonyultak a pikolin $\mathrm{N}$ oxidációjában. $^{134}$

\section{Réztartalmú komplexek interkalációja}

Mindösszesen négy publikáció találtunk ebben a témakörben. Az egyik, amelyikben a Mn-POM beépítéséról is olvashattunk, egy rézszubsztituált POM interkalálásáról számol be. ${ }^{126}$ A többiben kétféle Schiff-bázis, 2,2-bipiridin-5,5-dikarboxilát és 1,10-fenantrolin vagy 2,2'-bipiridin ligandummal kialakított interkalált komplexekről írnak. Az interkalálás mindegyik esetben a dehidratáció-rehidratáció módszerével zajlott. ${ }^{135-137}$ Az egyetlen közleményben, ahol nem MgAl-LDH, hanem ZnAl-LDH volt a gazda anyag, található az egyetlen példa katalitikus vizsgálatra. Azonban erről a kompozitról is bebizonyosodott, hogy nem mutat semmilyen aktivitást az etil-benzol oxidációjában.

\section{Nikkeltartalmú komplexek}

A mangán ion esetében a már említett átmenetifém-tartalmú, Keggin-ionhoz hasonló szerkezetü komplex anionok beépítését végrehajtották úgy is, hogy $\mathrm{Ni}$ (II)-t alkalmaztak központi ionként. ${ }^{126} \mathrm{Ni}(\mathrm{II})$-vel dópolt POM-ok interkalálását is elvégezték már a korábban leírtakhoz hasonlóan, valamint nikkel-ftalocianin komplexeket is sikerrel építettek be MgAl-LDH rétegei közé, felhasználva a réz-ftalocianin beépítésével kapcsolatos tapasztalatokat. ${ }^{138}$

Három olyan ligandummal is megvalósították az interkalálást, amelyet az eddig leírt fém ionoknál nem alkalmaztak. Nikkel-kloridokomplexeinek beépítéséről (vagy legalábbis a szándékról) több publikáció is beszámol. Elsőként nikkel-tetrakloridokomplexet, $\left[\mathrm{NiCl}_{4}\right]^{2-}$, szándékoztak interkalálni direkt anioncsere segítségével MgAl-LDH rétegei közé. ${ }^{139} \mathrm{Az}$ infravörös spektrumok alapján kiderült, hogy nem jártak sikerrel, mivel nem jelent meg a halokomplexekre jellemző rezgés $1400 \mathrm{~cm}^{-1}$ körül. Ugyanakkor a nitrátcsoport $v_{1}$ és $v_{5}$ rezgéseiből azt a következtetést vonták le, hogy kis mennyiségben sikerült nikkel-nitráto komplexet beépíteni a rétegek közé, amely komplexben a nikkelhez kétfogú ligandumként kapcsolódik a nitrátcsoport. ${ }^{140} \mathrm{~A}$ receptet később egy másik kutatócsoport módosította, és fázistranszfer katalizátor alkalmazásával próbálkozott. Erre 
azért volt szükség, mert a szintézisnek végig vízmentes, szerves közegben kellett lejátszatni, különben a nikkel ion a sokkal stabilisabb nikkel-hexaakva komplex $\left(\left[\mathrm{Ni}\left(\mathrm{H}_{2} \mathrm{O}\right)_{6}\right]^{2+}\right)$ formát vette volna fel. ${ }^{141}$ A változtatás eredményeként a felületi adszorpciót sikerült elérni, amit alátámasztottak az IR spektrumok, ugyanakkor a rétegtávolság csökkenés, amit tapasztaltak, azt jelentette, hogy a rétegek közé más, erősebben kötődő anionok jutottak be. Végül a sikeres szintézist, egy aprónak tűnő változtatás eredményezte. ${ }^{142} \mathrm{~A}$ fázistranszfer katalizátort tetrametil-ammónium-kloridról, tetraetilammónium-kloridra cserélték. A változtatás hatására a röntgen diffraktogramok alapján számolt rétegtávolságok az interkalálás sikerességét bizonyították. Végeztek UV-Vis-DRS (diffúz reflektancia spektroszkópia) méréseket, amelyekből kiderült, hogy háromféle nikkel vegyület található a rendszerben. A nikkel-tetraklorido komplex, az igen labilis nikkel-triklorido komplex, $\left[\mathrm{NiCl}_{3}\right]^{-}$, és a $\mathrm{NiCl}_{2}$. A két labilis komplexet annyira sikeresen stabilizálták, hogy viszonylag magas hőmérsékleteken (150-250 $\left.{ }^{\circ} \mathrm{C}\right)$ sem bomlottak el a rétegek között. Amennyiben vízben kevertették a kompozitot, azonnal kimosták a nikkel ionokat a rendszerből, vélhetően a leváló hexaakva komplexek formájában. Érdekesség, hogy síknégyzetes nikkel-klorido komplexet sikerrel építettek be $\mathrm{LiAl}_{2}-\mathrm{LDH}$ rétegeibe. $\mathrm{Az}$ azonban nem teljesen egyértelmü a cikk alapján, hogy megtörtént-e az ioncsere, vagy csupán felületi adszorpcióról van szó. ${ }^{143}$

$\mathrm{Ni}(\mathrm{II})$-EDTA komplexeket sikerrel építettek be MgAl-, LiAl $2^{-}$, valamint ZnAl-LDHba is, a dehidratáció-rehidratáció módszerét alkalmazva. ${ }^{144-146}$ Ezek az interkalálások egészen könnyen mentek, mert nagyon stabilis komplex képződött. Ni-citrát komplexeket is hasonlóan könnyen voltak képesek beépíteni MgAl-, és ZnAl-LDH-ba, mivel azonban a komplex mérete lényegesen kisebb az EDTA komplex méreténél, a direkt anioncsere módszerével is végre lehetett hajtani az interkalációt. ${ }^{147,148}$

Érdekesség, hogy a mágneses és ioncsere sajátságaikat ugyan vizsgálták ezeknek a beépített komplexeknek, de katalitikus felhasználásukra nem találtunk egyetlen példát sem az irodalomban.

\section{Vastartalmú komplexek interkalálása}

Három csoportra oszthatók azok a cikkek, amelyek vaskomplexek interkalálásával foglalkoztak. A legkézenfekvőbb megoldás a vaskomplexben való bevitelére az LDH rétegei közé a hexacianoferrát $\left(\left[\mathrm{Fe}(\mathrm{CN})_{6}\right]^{4-}\right)$ formában történő beépítés. Ilyen formában a Fe(II) beépítését MgAl-LDH-ba, az LDH-val foglalkozó cikkekhez képest nagyon korán, már 1978-ban publikálták. ${ }^{149}$ Nagyon könnyen cserélhetők voltak a rétegközi anionok; az interkalálás a direkt anioncsere módszerével történt. A szokásostól eltérően azt 
tapasztalták, hogy a rétegek közé egyáltalán nem interkalálódott karbonát ion, ami akkoriban újdonságnak számított. Az interkalálást könnyen lehetett bizonyítani a rétegtávolság változásával, valamint az IR spektrumokon megjelenő $v(\mathrm{CN})$-rezgés megjelenésével $\left(\sim 2000 \mathrm{~cm}^{-1}\right)$. Később nagyon sokan foglalkoztak a témával, csak a 90-es évek végéig húsznál több közlemény született ezen a területen. Ezekben két fontos dolgot állapítottak meg. Egyrészt kiderült, hogy hexacianoferrát ion a karbonát ionhoz hasonlóan a $\mathrm{C}_{3}$-tengelyére merőlegesen helyezkedik el a rétegek között és többszörösen negatív töltésü. Ez a magyarázat arra, hogy ez az ion képes versenyezni még a karbonát ionnal is. ${ }^{150}$ Másrészt a Mg:Al-arány csökkentésével egyre több hexacianoferrát épült be a rétegek közé. ${ }^{151}$ 5:1-es aránynál csak a karbonát ion beépülését tapasztalták, ugyanakkor 2:1-es aránynál már nem jelent meg az IR spektrumokban a karbonátra jellemző sáv.

Egy publikációban érdekes dologra hívták fel a figyelmet, miszerint hasonló adatok nyerhetők, ha azt feltételezik, hogy az interkalált anionok kb. $20 \%$-a $\left[\mathrm{Fe}(\mathrm{CN})_{6}\right]^{3-}$ formában van a rétegek között, és ezek $\mathrm{C}_{4}$ tengelyükre merölegesen épülnek be a rétegek közé. ${ }^{152}$

Ezt a felvetést később alaposan megvizsgálták. Megállapították, hogy mind $\left[\mathrm{Fe}(\mathrm{CN})_{6}\right]^{4-}$, mind pedig a $\left[\mathrm{Fe}(\mathrm{CN})_{6}\right]^{3-}$ forma megtalálható a rétegek között, függetlenül attól, hogy melyik formában építették be a komplexet a rétegek közé. ${ }^{153} \mathrm{Ez}$ azzal magyarázható, hogy az interkalálás során megtörténhet a Fe(III)-Fe(II) redukció, míg a szárítás során az oxidáció is végbemehet. Ezt az állítást mind Mössbauer, mind IR spektroszkópiával alátámasztották. ${ }^{154}$ Amennyiben az interkalálást direkt anioncserével végezték, és a cserélendő anion nitrát volt, úgy vegyes vas-ciano-nitrozo komplexek, $\left(\left[\mathrm{Fe}(\mathrm{CN})_{5} \mathrm{NO}\right]^{3-}\right.$ és $\left.\left[\mathrm{Fe}(\mathrm{CN})_{5} \mathrm{NO}\right]^{2-}\right)$ is keletkeztek. ${ }^{155}$ Ezt sikeresen alátámasztották azzal, hogy az IR spektrumokon $2000 \mathrm{~cm}^{-1}$ körül négy sáv is megjelent, amely jellemző a cianovegyes komplexek jelenlétére. A nitrozocsoportra jellemző rezgés $\left(\sim 1940 \mathrm{~cm}^{-1}\right)$ is megjelent a spektrumban. A későbbiekben többek között ZnAl-, CuAl-, NiAl-, és $\mathrm{LiAl}_{2}$ LDH-ba is sikeresen építették be a hexacianoferrát komplexeket. ${ }^{156-159}$ A kompozitok felhasználását azonban nem vizsgálták.

A kutatások másik jelentős iránya a porfirinátokomplexek beépítése. 2002-ből származik az első ezzel foglalkozó cikk. ${ }^{160}$ ZnAl-LDH-ba sikeresen interkaláltak különböző vízoldható $\mathrm{Fe}(\mathrm{III})$-porfirináto komplexeket, két különböző módszerrel. Az együttes lecsapás módszerével a felületi megkötődést sikerült elérniük, míg a dehidratációrehidratáció módszerével a rétegek közé építették be a komplexet, amit a diffraktogramok alá is támasztottak. A kompozitot felhasználták a ciklohexán oxidációja során katalizátorként, és maximálisan 66\%-os konverzióval és 90\% körüli alkohol 
szelektivitással ment végbe a folyamat. Érdekesség, hogy ezt az eredményt akkor kapták, ha jódbenzolt használtak oxidálószerként, ugyanakkor hidrogén-peroxid felhasználásával jóval gyengébb eredményeket nyertek. Később sikeresen építettek be MgAl-LDH rétegei közé delaminálással és ZnAl-LDH rétegei közé a dehidratáció-rehidratáció módszerével is a porfirinátokomplexeket, és megállapítható volt az összes esetben, hogy elfogadható aktivitással ( 30-60\%) és magas szelektivitással voltak képesek katalizálni a különböző olefinek, és alkoholok oxidációját. ${ }^{161-167}$ Érdemes megjegyezni, hogy a legtöbb esetben a jódbenzol volt a megfelelő oxidálószer és a többi oxidálószerrel nem, vagy alig mentek a reakciók.

A harmadik nagy csoportban szulfonáto-Schiff bázis, például szulfonáto-szalén komplexeket interkaláltak. ${ }^{133,168,169}$ Az összes esetben ugyanúgy zajlott a szintézis. Az első lépésben együttes lecsapással állítottak elő benzoesavtartalmú MgAl-LDH-t (vagy ZnAlLDH-t), majd a benzoátot cserélték a komplex anionra a direkt anioncsere módszerével. Hasonlóan a porfirinátokomplexekhez, ezek a kompozitok is aktív katalizátoroknak bizonyultak oxidációs eljárásokban.

Meg kell jegyezni, hogy ftalocianin-, oxalát-, valamint citrátkomplexek beépítéséről is beszámoltak már korábban, ezek katalitikus aktivitását azonban nem vizsgálták, vagy - a ftalocianinkomplex esetében - a konverzió elhanyagolható volt. ${ }^{170,171}$

Az eddigieket összegezve elmondható, hogy egyetlen példát sem találtunk ,,ship in bottle" szintézismódszerre, vagyis arra, hogy a komplexet a rétegek között hozták volna létre. A réz- és nikkeltartalmú komplexek esetében nem volt fellelhető példa katalitikus aktivitások vizsgálatára sem. Tovább egyetlen példát sem találtunk arra, hogy fém ionaminosav komplexet építettek volna be az LDH rétegei közé. 


\section{Célkitüzés}

Az értekezéshez vezető kísérleti munka céljai a következők voltak:

- aminosavak (L-cisztein, L-tirozin, L-hisztidin) átmeneti fém ionokkal (Mn(II), $\mathrm{Cu}(\mathrm{II}), \mathrm{Ni}(\mathrm{II}), \mathrm{Fe}(\mathrm{III}))$ alkotott komplexeinek kialakítása CaAl-LDH-ban,

- az interkalálás körülményeinek optimalizálása,

- az interkalálás sikerességének bizonyítása és a kapott szerkezetek széleskörü jellemzése,

- a kialakított kompozitok katalitikus viselkedésének vizsgálata redoxi és kapcsolási reakciókban.

- a katalitikus reakció körülményeinek optimalizálása. 


\section{Kísérleti rész}

\subsection{CaAl-LDH szintézise}

A minimális karbonáttartalmú, koncentrált $\mathrm{NaOH}(\sim 20 \mathrm{M})$ törzsoldatot Millipore MilliQ víz és a.r. tisztaságú szilárd $\mathrm{NaOH}$ felhasználásával készítettük. Az oldat sűrűségének meghatározásával állapítottuk meg a pontos koncentrációt. Felhasználásig az oldatot Pyrex üvegben tároltuk, levegőtől gondosan elzárva. A kísérletek során a különböző koncentrációjú $\mathrm{NaOH-oldatokat} \mathrm{ebből} \mathrm{az} \mathrm{oldatból,} \mathrm{hígítással} \mathrm{készítettük.}$

$\mathrm{Ca}\left(\mathrm{NO}_{3}\right)_{2} \cdot 4 \mathrm{H}_{2} \mathrm{O}$, valamint $\mathrm{Al}\left(\mathrm{NO}_{3}\right)_{3} \cdot 9 \mathrm{H}_{2} \mathrm{O}$ sókat használva, az együttes lecsapás módszerével állítottuk elő CaAl-LDH-t. A szintézis során a sók közös oldatának $100 \mathrm{~cm}^{3}$ ét csepegtettük a lúgoldathoz, amelynek a pH-ját 13,1-re állítottuk be. A törzsoldat kalciumra nézve 0,3 M, míg alumíniumra nézve 0,15 M koncentrációjú volt. A szintézis során $\mathrm{N}_{2}$-atmoszférát alkalmaztunk a karbonátosodás elkerülése érdekében. A szuszpenziót 24 órán át kevertettük, majd szürtük, az anyalúggal mostuk nagy felesleget alkalmazva $\left(150 \mathrm{~cm}^{3}\right)$, végül a szilárd anyagot 24 órán keresztül $60{ }^{\circ} \mathrm{C}$-on szárítottuk.

\subsection{Aminosav komplexek interkalálása}

A fém ion-aminosav komplexek az LDH rétegei közötti kialakítására kétféle módszer alkalmaztunk. Mindkét szintézisút során a direkt anioncsere módszerével dolgoztunk.

A módszer

Az A módszer esetében az aminosavat interkaláltuk az első lépésben, majd ezt követte a rétegek közötti komplexképzés. Az első lépésben $2,5 \cdot 10^{-3}$ mol L-tirozint, Lhisztidint, illetve L-ciszteint alkalmaztunk. Az aminosav törzsoldathoz annyi NaOHoldatot ( 0,1 M) adagoltunk, hogy az aminosavak anionos formába kerüljenek. Az aminosav törzsoldathoz $\left(100 \mathrm{~cm}^{3}\right)$ szilárd LDH-t $(0,3 \mathrm{~g})$ adagoltunk, majd az így kialakított szuszpenziót 168 órán át kevertettük. Ezt követően szürtük, mostuk és szárítottuk az interkalált kompozitot, a fentebb már leírt módszerrel. A beépülést mennyiségileg meghatároztuk UV-Vis spektrometria segítségével. Ezek után elkészítettük a fémsók $\left(\mathrm{Mn}\left(\mathrm{NO}_{3}\right)_{2} \cdot 4 \mathrm{H}_{2} \mathrm{O}, \mathrm{Cu}\left(\mathrm{NO}_{3}\right)_{2} \cdot 3 \mathrm{H}_{2} \mathrm{O}, \mathrm{Ni}\left(\mathrm{NO}_{3}\right)_{2} \cdot 6 \mathrm{H}_{2} \mathrm{O}, \mathrm{Fe}\left(\mathrm{NO}_{3}\right)_{3} \cdot 9 \mathrm{H}_{2} \mathrm{O}\right)$ törzsoldatát, majd ehhez szilárd formában adagoltuk az aminosav anionokkal interkalált LDH-t $(0,3 \mathrm{~g})$. Az így kialakított szuszpenziót 24 órán át kevertettük, majd szürtük, mostuk és szárítottuk. A pH ( 7,5-10,5), az aminosav:fém ion arány (2:1-6:1), valamint az alkalmazott 
oldószer/elegy (víz, víz:etanol $=1: 10$, víz:aceton $=1: 10$ ) voltak a változtatott szintézisparaméterek a második lépés során. Az ezzel a módszerrel elöállított kompozitokra a továbbiakban CaAl-M(II)/M(III)-aminosav anion-LDH elnevezéssel fogunk hivatkozni.

B módszer

Ebben az esetben a komplexeket az interkalálást megelőzően, oldatban készítettük el. Ezt követően a komplex oldatához adagoltunk 0,3 g nitráttartalmú LDH-t, a szuszpenziót 24 órán keresztül kevertettük, majd szürtük, mostuk és szárítottuk a szilárd mintát. A szintézis során végig $\mathrm{N}_{2}$-atmoszférát alkalmaztunk, akárcsak az A módszer esetében. A továbbiakban a B módszer szerint készült mintákra M(II)/M(III)-aminosav anion-CaAlLDH elnevezéssel fogunk hivatkozni.

\subsection{Szerkezetvizsgálati módszerek}

\subsubsection{Az LDH jellemzése}

A (por)röntgen diffraktogramokat $2 \theta=4-40^{\circ}$ tartományban, $4 \%$ perc pásztázási sebesség mellett, egy Rigaku Miniflex II készüléken vettük fel $\operatorname{CuK} \alpha(\lambda=1,5418 \AA)$ sugárzást használva. A reflexiók pozíciói $0,05^{\circ}$ pontossággal voltak reprodukálhatók. A röntgen diffraktometriás (XRD) mérések segítségével megállapítatható, hogy a kompozit réteges szerkezetü-e, illetve a rétegtávolság változásból következtethetünk az aminosav komplexek beépítésének sikerességére. A kompozitok morfológiáját pásztázó elektronmikroszkópia (SEM) segítségével vizsgáltuk, 10-18 kV gyorsítófeszültséget alkalmazva. Egy Hitachi S-4700-as berendezéssel készültek a felvételek. A SEM-hez kapcsolt energiadiszperzív röntgenanalizátor (SEM-EDX) segítségével az elemeloszlásról nyerhettünk információkat. A mérések során egy Röntec QX2 detektor állt rendelkezésre.

\subsubsection{Mennyiségi meghatározás}

$\mathrm{Az}$ aminosavtartalom mennyiségi meghatározására UV-Vis spektrometriát alkalmaztunk, ugyanis L-cisztein esetében 231 nm-nél, L-hisztidin esetében 210,5 nm-nél, míg L-tirozin esetében 273,5 nm-nél található egy, az adott aminosavra jellemző elnyelés. Hígítási sor elkészítésével, valamint a Lambert-Beer törvény alkalmazásával meg lehetett állapítani az oldatban maradt aminosav mennyiségét. A meghatározást mind az interkalálási, mind a komplexképzési lépéseket követően elvégeztük. A mérésekhez egy Shimadzu UV-1650 spektrofotométert használtunk. A fém ionok mennyiségi megahatározása egy Thermo’s IRIS Intrepid II ICP-OES spektrométerrel történt. A mérés 
elött néhány mg interkalált LDH-t oldottunk fel $1 \mathrm{~cm}^{3}$ cc. $\mathrm{H}_{2} \mathrm{SO}_{4}$-ben, majd az oldatot 50 $\mathrm{cm}^{3}$-re hígítottuk desztillált vízzel.

4.3.3. A komplexek szerkezetvizsgálata, az interkalálás bizonyítása

Röntgenabszorpciós spektroszkópia (XAS)

A XAS több szempontból is fontos információt szolgáltatott az interkalált komplexekről. Egyrészt meg tudtuk határozni a beépített fém ion oxidációs állapotát, másrészt kvantitatív információkat nyerhettünk a rétegközi komplexek szerkezetéről (koordinációs szám, kötéshosszak).

A XAS alapját fotoeffektus képzi, miszerint a 2500-30000 eV tartományba eső nagyenergiájú röntgensugárzás hatására a besugárzott mag egy belső héjáról (általában $\mathrm{K}$ vagy L-héjak valamelyikéről) egy elektron lökődik ki. ${ }^{172,173}$ A relaxáció során ez az elektron pótlódik egy magasabb energiaszintű héjról, és a két energiaszint közötti energiakülönbséget a minta kisugározza foton formájában. A kisugárzott foton kinetikus energiája, a röntgenfoton és az elektron kötési energiája közötti különbségeként adódik. A folyamat során a röntgensugárzás abszorpciós koefficiense csökken a foton energiájának növekedésével, egészen addig, amíg el nem érjük a belső elektron kötési energiáját (ezt nevezzük küszöbenergiának). A küszöbenergia elérése után egy éles csúcs jelenik meg a spektrumon. A csúcs előtti spektrumszakaszt, két különböző részre szokták osztani. Az abszorpciós él előtti szakasz az első (pre-edge), amely információt hordoz a koordinációs geometriáról. A következő szakasz, amely a csúcsot és annak közvetlen környezetét tartalmazza, a XANES régió (X-ray absorption near edge spectroscopy). A csúcs pontos helyéből megállapítható a besugárzott elem oxidációs állapota, valamint a XANES spektrum lefutása kapcsolatban van a lokális geometriával, valamint a kapcsolódó ligandumok típusával. 

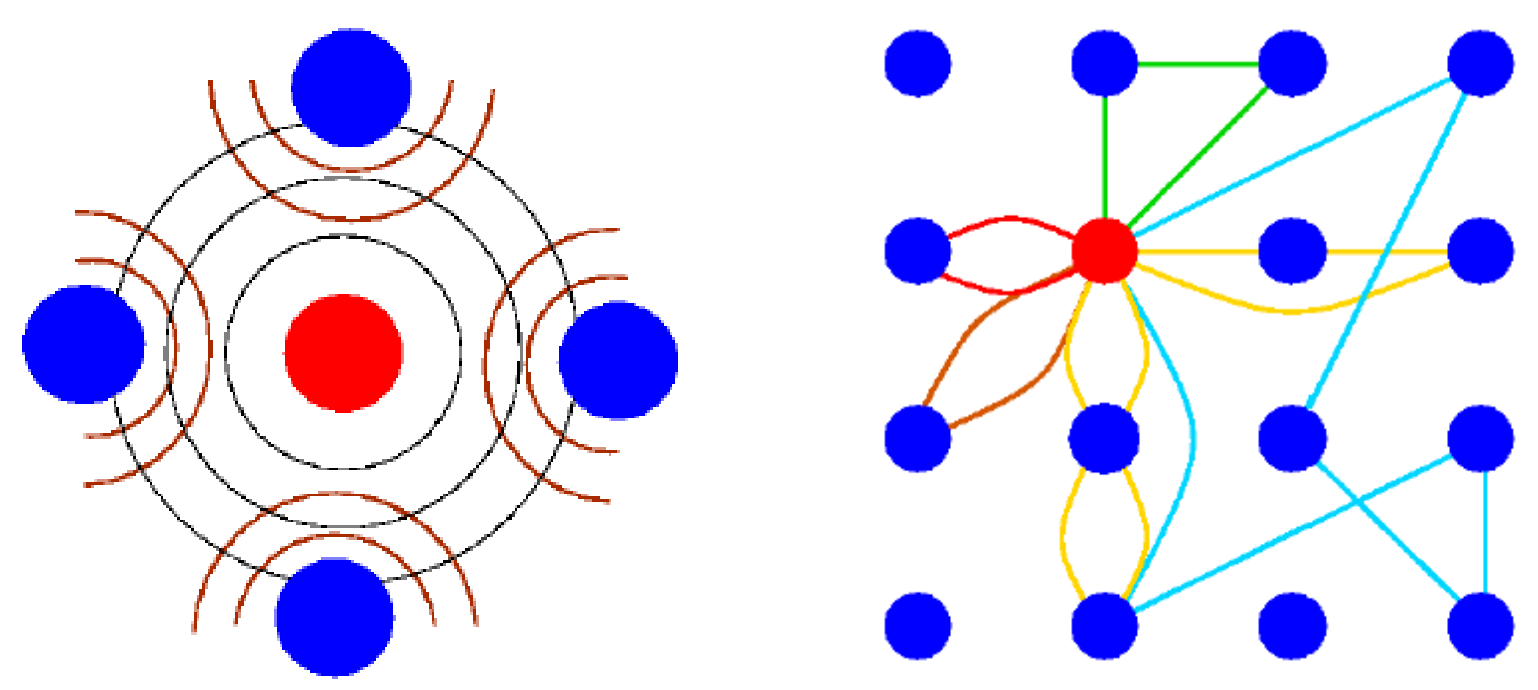

2. ábra: A szórás és a többszörös szórás jelensége a röntgenabszorpciós spektroszkópiában.

Az abszorpciós koefficiens a csúcs után újra csökkenni kezd, és a csúcs utáni körülbelül 1000 eV-os tartományt hívják a spektrum finomszerkezetének (extended X-ray absorption fine structure - EXAFS). Ez a finomszerkezet úgy alakul ki, hogy a fotonok a gerjesztett mag közelében lévő atomokról visszaszóródnak és interferálnak az eredeti foton hullámmal (2. ábra). A sugárzás nem csupán egyetlen atomról szóródhat vissza, ezt a jelenséget hívják többszörös szórásnak. Az EXAFS régió adatainak az illesztésével kaphatjuk meg az interatomos távolságokat, valamint a koordinációs számot.

A röntgenabszorpciós spektrumokat a svédországi Lund Egyetem MaxLab szinkrotronjában, az I811 állomáson vettük fel a Fe/Mn/Cu/Ni K éleken. A mérőállomás egy szupravezető sugárforrás, ami a 1,5 GeV gyorsító feszültségű MAX II tárológyürühöz kapcsolódik. A foton fluxus megközelítőleg $2 \cdot 10^{15}$ foton/s volt. A mérések során mind a transzmissziós, mind a fluoreszcenciás technikával készült spektrumokat detektáltuk, ám a mért spektrumok jobb minősége miatt a fluoreszcenciás adatokat használtuk az illesztés során. A mérési adatok illesztését az EXAFSPACK és FEFF7 programcsomagok segítségével végeztük el. ${ }^{174,175}$ Az illesztés során megtörtént a spektrumok normálása és az atomi háttér kivonása is. A spektrumokat $\mathrm{k}^{3}$ szerint súlyoztuk, és Fourier-transzformáltuk a 2-9,5 $\AA^{-1}$ tartományban. Az illesztett paraméterek közül az interatomos távolságokat (R), a koordinációs számokat $(\mathrm{N})$, a Debye-Waller faktorokat $\left(\sigma^{2}\right)$, valamint az $\mathrm{F}$ faktorokat adtuk meg a táblázatokban. Az F faktor jellemzi az illesztés jóságát. Ez egy dimenzió nélküli arányszámból képzett százalékos adat, amelynek értéke 0,2 alatt (20\%) elfogadható, mint jó illesztés.

IR spektroszkópiai módszerek 
Három különböző IR spektroszkópiai detektálási módszert alkalmaztunk annak eldöntésére, hogy az aminosav döntően a rétegközi térbe, vagy az LDH külső felületére kötődött. A mérésekhez egy BIO-RAD Digilab Division FTS-65A/896 FT-IR spektrofotométert alkalmaztam, amelynek felbontása $4 \mathrm{~cm}^{-1}$ volt. Az összes spektrum esetében 256 interferogramot gyüjtöttem a $4000-600 \mathrm{~cm}^{-1}$ tartományban. A mérésekhez használtunk fotoakusztikus (PA) detektort (MTEC 200, $2500 \mathrm{~Hz}$ szkennelési sebesség) és ATR (attenuated total reflection - gyengített totálreflexió) feltétet (Diamond Split) is. A könnyü mintaelökészítés miatt, sok esetben diffúz reflektancia spektrumokat (DRS) vettünk fel.

$\mathrm{Az}$ alkalmazott szkennelési sebesség mellett a PA technika behatolási mélysége körülbelül $20 \mu \mathrm{m}$, ami azt jelenti, hogy döntően a minták belsejéről, azaz a rétegközi térről kapunk információt ezzel a módszerrel. ${ }^{176}$

Az ATR feltétet azért használtuk, hogy a minta külső felületéről nyerjünk információkat. Ugyan a módszert felületérzékenynek tartják, ám akár $10 \mu \mathrm{m}$ is lehet a módszer behatolási mélysége. Az aktuális behatolási mélységet a következő paraméterek befolyásolják:

- az ATR kristály és a minta törésmutatója,

- az infravörös sugárzás beesési szöge,

- a kritikus szög $\left(\theta_{\mathrm{c}}\right)$,

- az infravörös sugárzás hullámhossza,

- a reflexiók száma,

- az ATR kristály anyaga,

- a mintának a felülettel való minél szorosabb illeszkedése.

$$
\begin{gathered}
\theta c=\sin ^{-1}\left(\frac{\mathrm{n}_{2}}{\mathrm{n}_{1}}\right) \\
\mathrm{d}_{\mathrm{e} \perp}=\frac{\mathrm{n}_{1}^{2} \times \mathrm{n}_{2} \times \cos \theta}{\left(\mathrm{n}_{1}^{2}-\mathrm{n}_{2}^{2}\right)} \times \frac{\lambda}{\pi \times \sqrt{\mathrm{n}_{1}^{2} \times \sin ^{2} \theta-\mathrm{n}_{2}^{2}}} \\
\mathrm{~d}_{\mathrm{e} \|}=\frac{\mathrm{n}_{1}^{2} \times \mathrm{n}_{2} \times \cos \theta}{\left(\mathrm{n}_{1}^{2}-\mathrm{n}_{2}^{2}\right)} \times \frac{2 \times \mathrm{n}_{1}^{2} \times \sin ^{2} \theta-\mathrm{n}_{2}^{2}}{\left(\mathrm{n}_{1}^{2}-\mathrm{n}_{2}^{2}\right) \times \sin ^{2} \theta-\mathrm{n}_{2}^{2}} \times \frac{\lambda}{\pi \times \sqrt{\mathrm{n}_{1}^{2} \times \sin ^{2} \theta-\mathrm{n}_{2}^{2}}} \\
\mathrm{~d}_{\mathrm{e}}=\frac{\mathrm{d}_{\mathrm{e} \|}+\mathrm{d}_{\mathrm{e}} \perp}{2}
\end{gathered}
$$

4-7. egyenlet: Az ATR technika behatolási mélységét leíró egyenletek, ahol: $\theta_{\mathrm{c}}$ : kritikus szög, $\mathrm{n}_{1}$ : az ATR kristály törésmutatója, $\mathrm{n}_{2}$ : a minta törésmutatója, $\theta$ : az IR sugárzás beesési szöge, $\mathrm{d}_{\mathrm{e}}$ : 
effektív behatolási mélység, $\mathrm{d}_{\mathrm{el}}$ : az effektív behatolási mélység párhuzamos komponense, $\mathrm{d}_{\mathrm{e}} \perp$ : az effektív behatolási mélység merőleges komponense.

A $10 \mu \mathrm{m}$-es mélység eléréséhez elengedhetetlen, hogy többszörös visszaverödésű ATR feltétet alkalmazzunk. Az általunk használt feltét azonban egyszeres visszaverődésű. Az így elérhető elméleti maximális behatolási mélység már csak $2 \mu \mathrm{m}$. Gyémánt kristály használata esetén, $45^{\circ}$-os beesési szöget alkalmazva olyan mintán, amelynek a törésmutatója 1,5 körül van, mint az LDH-k esetében is, 1,66 $\mu$ m-nek adódik a behatolási mélység. Ugyanakkor ez az érték csupán azt adja meg, hogy az evaneszcens hullám milyen mélységbe jut el, de ez nem egyezik meg azzal az értékkel, ami leírja, hogy mekkora mélységből nyerhetünk még információt - ezt nevezik effektív behatolási mélységnek. Ez a mi kísérleti elrendezésünkkel (DTGS detektor) körülbelül $0,8 \mu \mathrm{m}$. Ez az effektív behatolási mélység $1000 \mathrm{~cm}^{-1}$ hullámszám esetében valósul meg, értéke csökken a nagyobb hullámszámoknál. Két további hatás csökkentheti ezt az értéket. A mintának tökéletesen illeszkednie kellene a kristályhoz, ez habok illetve réteges anyagok esetében nagyobb nyomást igényelne, de ennek alkalmazására nem volt lehetőségünk, mert nem bírta volna ki a réteges szerkezet.

A másik még jelentősebb hatás az LDH-hoz köthető. A hidrokalumitra és a hidrotalcitra jellemző a kettős törés jelensége. Ez pedig azt jelenti, hogy a minta a fény (a minta optikai tengelyéhez képest) párhuzamos illetve merőleges komponensét másképpen töri, így két különböző behatolási mélységet eredményezve. Mivel az effektív behatolási mélység erősen függ ettől a jelenségtől, lásd 1. egyenletrendszer (7)-es egyenlete, így ez a jelenség erősen csökkentheti az effektív behatolási mélységet. ${ }^{177}$

Mindezekből következően azt mondhatjuk, hogy az ATR technika alkalmazásával dominánsan, de nem kizárólag a felületen megkötődött anionokat detektálhatjuk.

Távoli IR spektroszkópia (FIR)

Annak érdekében, hogy a különböző fém-donoratom $\left(\mathrm{O}_{\text {karboxilát, }}, \mathrm{O}_{\text {fenolát }}, \mathrm{N}_{\mathrm{amino}}\right.$, $\mathrm{N}_{\text {imidazolát }}$ ) azonosítani tudjuk, felvettük a kompozitok távoli IR spektrumait. A méréshez a Nujol Mull technikát használtuk, amely során paraffinolajban szuszpendáltattunk $10 \mathrm{mg}$ LDH-t, majd ezt követően a szuszpenziót vékony rétegben két polietilén ablak közé vittük fel. A méréseket egy BIO-RAD Digilab Division FTS-40 vacuum FT-IR spektrofotométeren végeztem el $4 \mathrm{~cm}^{-1}$ felbontással, minden egyes spektrumhoz 256 inteferogramot gyüjtve. A mérések értékeléséhez egy korrelációs táblázatot használtam (2. táblázat), amelyet korábban a kutatócsoportunkban dolgoztuk ki és publikáltuk. ${ }^{178}$ 
1. táblázat: Távoli IR korrelációs táblázat, a kötésekhez tartozó értékek $\left(\mathrm{cm}^{-1}\right)$.

\begin{tabular}{ccccc}
\hline Központi fém & \multicolumn{4}{c}{ Koordináló donorcsoportok } \\
\cline { 2 - 5 } ionok & $\mathrm{O}_{\text {fenolát }}$ & $\mathrm{O}_{\text {karboxilát }}$ & $\mathrm{N}_{\text {amino }}$ & $\mathrm{N}_{\text {imidazolát }}$ \\
\hline $\mathrm{Mn}(\mathrm{II})$ & 310 & 351 & 372 & 274 \\
$\mathrm{Ni}(\mathrm{II})$ & 305 & 343 & 373 & 263 \\
$\mathrm{Cu}(\mathrm{II})$ & 301 & 340 & 377 & 291 \\
$\mathrm{Fe}(\mathrm{III})$ & 314 & 352 & 366 & 255 \\
\hline
\end{tabular}

\section{Raman spektroszkópia}

Kiegészítő módszerként alkalmaztuk annak az eldöntésére, hogy a beépített ciszteinát ion oxidálódott-e cisztináttá. A módszer fontos volt abból a szempontból is, hogy megállapíthassuk azt, hogy a kénatom részt vesz-e a koordinációban. A rögzített komplexeket porítás után egy NMR csőbe töltöttük és felvettük a spektrumokat. Egy minta színképének felvételéhez 1024 interferogrammot gyüjtöttünk, $4 \mathrm{~cm}^{-1}$ felbontás mellett. A spektrumok értékelése során alkalmaztunk alapvonal-korrekciót, illetve ha szükséges volt, simítást is. A méréseket egy BIO-RAD Digilab Division FT-Raman spektrométeren végeztük el.

\section{Elektonspin rezonancia (ESR) spektroszkópia}

A komplexek geometriájáról, valamint a kapcsolódó donoratomokról az ESR spektroszkópia segítségével tájékozódhattunk a $\mathrm{Mn}$ (II) valamint a $\mathrm{Cu}(\mathrm{II})$ ionokat tartalmazó kompozitok esetében. A koordinálódó donoratomok azonosítását irodalmi analógiák segítették. Egy BRUKER EleXsys E500 spektrométer állt rendelkezésünkre a mérések kivitelezéséhez. A mérések során $12 \mathrm{~mW}$ teljesítményü és 9,51 GHz frekvenciájú mikrohullámú sugárzást alkalmaztunk, $5 \mathrm{G}$ modulációs amplitúdóval és $100 \mathrm{kHz}$ modulációs frekvenciával. A mérések minden esetben szobahőmérsékleten történtek, kvarc ESR-csőben, adalékanyag hozzáadása nélkül.

\subsubsection{Molekuláris szintű modellalkotás}

A beépített aminosav komplexek méreteinek meghatározása, és térbeli modelljének a megalkotása, a mért diffrakciós és spektroszkópiai adatok alapján, a Hyperchem 8.0 programmal történt. Csak a program rajzolási és méretezési képességeit használtuk, az ábrázolást teljes mértékben kísérleti adatok alapján végeztük el. Megkerestük azt a legkisebb téglatestet, amelyben elhelyezhetőek a komplexek. Ennek a téglatestnek az élhosszai lettek a komplexek dimenziói. 


\subsection{A katalitikus aktivitás vizsgálata}

Az egyik, minden kompozit estén használt tesztreakció a ciklohexén oxidációja volt. Magas aktivitás és szelektivitás elérésnek érdekében optimalizáltuk a reakciókörülményeket. Változtattuk a felhasznált katalizátor mennyiségét (5-45 mg), a reakció hőmérsékletét $\left(15-55^{\circ} \mathrm{C}\right)$, a reakcióidőt (1-24 óra) valamint az alkalmazott oldószert (etanol, aceton, diklór-metán). Vizsgálatainkban kétféle oxidálószert (perecetsavat vagy diacetoxi-jódbenzolból in situ képződő jodozilbenzolt) használtunk. A reakciólegyek kiindulási összetétele mindig $5 \mathrm{mmol}$ ciklohexén, 2,5 mmol oxidálószer, valamint $10 \mathrm{~cm}^{3}$ oldószer volt.

$\mathrm{Cu}(\mathrm{II})$ - és $\mathrm{Fe}(\mathrm{III})$-tartalmú rendszerek ugyanakkor aktívak voltak egy kapcsolási reakcióban, jelesen a jód-benzol és fenol Ullmann-típusú éterképződési reakciójában is. Ebben a reakcióban a reakcióhőmérséklet $\left(25-110^{\circ} \mathrm{C}\right)$, a katalizátor mennyisége (15$100 \mathrm{mg}$ ), az alkalmazott oldószer (DMF, etanol, toluol) valamint az alkalmazott bázis (piridin, piperidin, $\mathrm{Na}_{2} \mathrm{CO}_{3}, \mathrm{~K}_{2} \mathrm{CO}_{3}$ ) voltak a változtatott paraméterek. A reakcióelegyek kiindulási összetétele $0,6 \mathrm{mmol}$ jódbenzol, $0,5 \mathrm{mmol}$ fenol, $0,5 \mathrm{mmol}$ bázis, valamint 5 $\mathrm{cm}^{3}$ oldószer (szervetlen bázisok esetén még $0,5 \mathrm{~cm}^{3}$ víz, mint segédoldószer) volt.

Minden esetben üstreaktort alkalmaztunk. A reakciók nyomon követése gázkromatográfiásan történt (Hewlett-Packard 5890 Series II gázkromatográf, Agilent HP1 kolonna, lángionizációs detektor). Mennyiségi meghatározás céljából a belső standard módszert használtuk. A ciklohexén oxidációja során toluol, míg az Ullmann-típusú reakcióban metanol volt az alkalmazott belső standard. A termékeket előre megvásárolt tiszta anyagok kromatogramjai alapján azonosítottuk. 


\section{Eredmények és értékelésük}

\subsection{Aminosav komplexek kiépítése CaAl-LDH rétegei között}

Amint azt a Kísérleti részben már említettük, a komplexek kiépítésére az LDH rétegei között két módszert használtunk. Először az A módszer (az aminosav interkalálása először, úgy hogy a savból az interkalálás során készítjük az aniont lúgos vizes, vagy lúgos vizes etanolos, vagy lúgos vizes acetonos oldat segítségével, majd ezután következik a fémkomplex kiépítése) alkalmazásával kapott eredményeket részletezzük. Ezt követően a $B$ módszer eredményeit (a fém ion-aminosav komplex szintézisét követően kíséreljük meg a komplex anionos formáját a rétegek közé juttatni) taglaljuk. Mindkét fajta szintézismódszer alkalmazásakor az volt az elsődleges cél, hogy a fém ion-aminosav anion komplexet úgy építsük be a rétegek közé, hogy a felületi megkötődést minimalizáljuk.

A sikeres interkalálást az LDH röntgen diffractogramján a karakterisztikus reflexióik elmozdulása bizonyítja minden kétséget kizáróan. Amennyiben ezek a kisebb $2 \theta$ irányba tolódtak el, akkor a rétegtávolság nőtt, ha az elmozdulás ellentétes irányú, akkor pedig csökkent.

Az aminosav anionok jelenlétének bizonyítására az IR spektrumok is alkalmasak lehetnek. Amennyiben új, az interkalálandóhoz ionhoz köthető sávok jelennek meg a spektrumokon, akkor kijelenthető, hogy a rendszerben megtalálható az adott anion. Ha azok a karakterisztikus rezgések, amelyek töltéshordozó csoporthoz köthetők, eltolódtak, akkor elmondható, hogy kölcsönhatás lép fel a vendég ion és a gazda LDH rétegei között. Ha az ATR feltéttel készült spektrumok nem különböznek a tiszta CaAl-LDH (tiszta CaAlLDH alatt a szerves aniont nem tartalmazó mintát értjük) spektrumától (akármilyen mérési módszerrel is rögzítettük azokat), de a PA-IR spektrumokon láthatunk új sávokat, akkor a szerves anion (vagy a $B$ módszer esetén a komplex anion) döntően a rétegek között található. Amennyiben az ATR-IR, illetve a PA-IR spektrumok hasonlóak, akkor a felületi megkötődés sem hanyagolható el.

A szintézismódszerek, illetve azokon belül a szintézisparaméterek változtatásának hatásait a Mn(II)-tartalmú rendszereken, különösen részletesen pedig a $\mathrm{Mn}(\mathrm{II})$-hisztidinát komplex rétegközi kialakításának kísérleti eredményein keresztül mutatjuk be. A többi fém ion esetén csak a katalitikus vizsgálatokra kiválasztott kompozitok szintézisét és jellemzését tárgyaljuk. 


\subsubsection{Az A módszer}

\section{Az aminosav anionok interkalálása}

A hisztidinát ion interkalálási kísérletei során azt tapasztaltuk, hogy bármilyen oldószerrel, oldószer eleggyel is dolgoztunk, nem volt mérhető rétegtávolság változás (3/a ábra). Ez valószínűleg azt jelenti, hogy a rétegközi térben megtalálható nitrát ionokat nem sikerült lecserélni. Ugyanakkor új rezgések jelentek meg a kompozitok IR-DRS spektrumain (3/b ábra). Ezek közül egyértelmüen azonosíthatók a hisztidinát aszimmetrikus és szimmetrikus karboxilát rezgései $\left(1630\right.$ és $\left.1410 \mathrm{~cm}^{-1}\right)$. Ezek a rezgések az aminosav nátriumsójának spektrumában 1590 és $1490 \mathrm{~cm}^{-1}$-nél találhatók, azaz a kompozitban eltolódtak. Tehát nagy valószínüséggel kölcsönhatás, mégpedig ionos kölcsönhatás alakult ki az LDH rétegei és a karboxilát ionok között, azaz nem elhanyagolható mértékü felületi megkötődés történt.

Vizes etanolt választottuk oldószerként a további kísérletekben. A másik két oldószer/oldószer elegy is szóba jöhetett volna, azonban az irodalmi eredmények és a csoport eddigi munkái alapján maradtunk a vizes etanolnál.

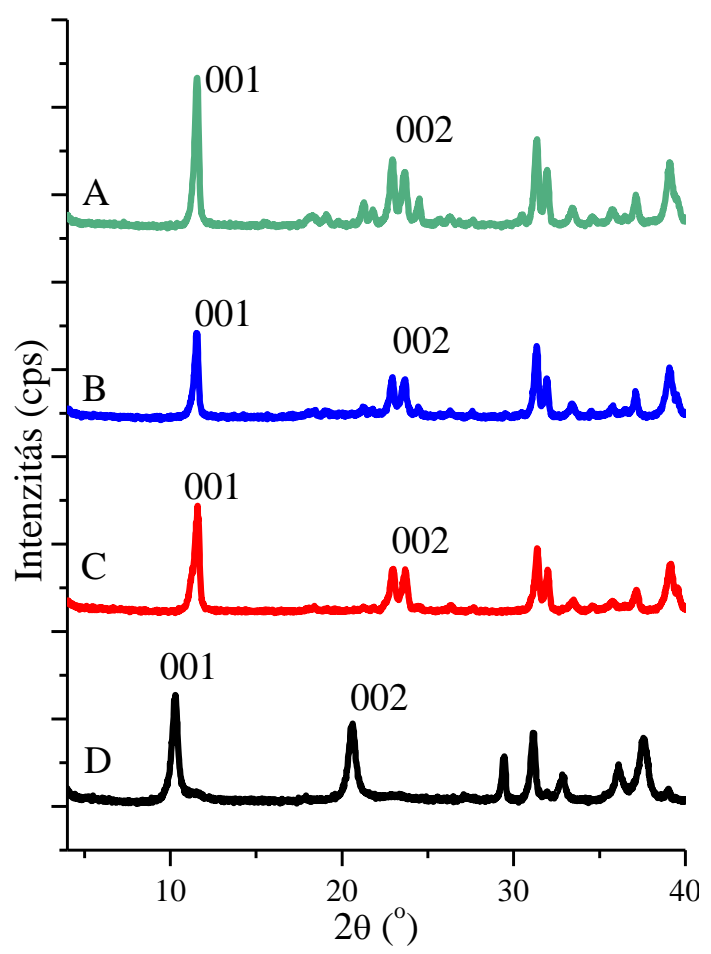

(a)

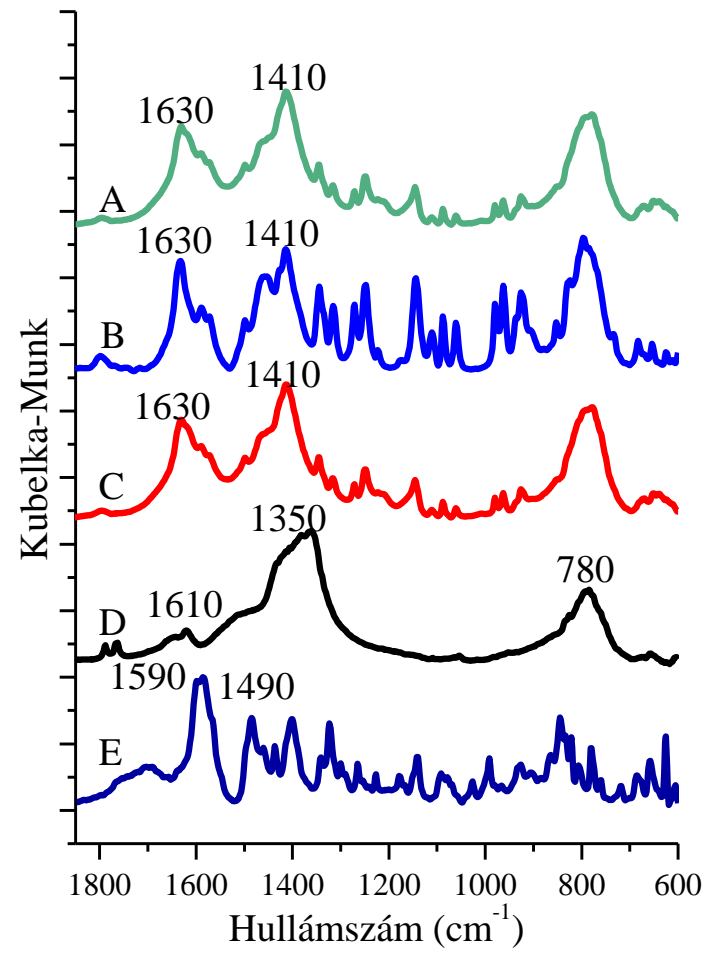

(b)

3. ábra: Hisztidináttartalmú CaAl-LDH-k röntgen diffraktogramjai (a) és IR spektrumai (b), A: víz; B: vizes etanol; C: vizes aceton; D: CaAl-LDH, E: Na-hisztidinát $\left(\mathrm{c}_{\mathrm{His}}=5 \cdot 10^{-2} \mathrm{M} ; \mathrm{T}=25^{\circ} \mathrm{C}\right.$; $\mathrm{pH}=9,7)$ - az oldószer hatása. 
A következő lépés a szintézishőmérséklet emelése volt. Ez sajnos nem javította az interkalálás hatékonyságát - a 001 és 002 reflexiók az összes kompozit esetében megmaradtak a kiindulási $10,5^{\circ}$ és $21,0^{\circ} 2 \theta$ érték körül, tehát a rétegközi térbe való beépítés ebben az esetben sem járt sikerrel (4/a ábra). A 4/b ábrán továbbra is azt láthatjuk, hogy megjelentek az aminosavra jellemző rezgések, továbbá azt is, hogy a karboxilát rezgések elmozdultak a hordozóra rögzítés hatására $\left(1590 \mathrm{~cm}^{-1}\right.$-röl $1630 \mathrm{~cm}^{-1}$-re és 1490 $\mathrm{cm}^{-1}$-röl $1410 \mathrm{~cm}^{-1}$-re). Mivel a szintézishőmérséklet emelése nem volt hatásos, ezért a továbbiakban a kényelmesen tartható $25{ }^{\circ} \mathrm{C}$-on dolgoztunk tovább.

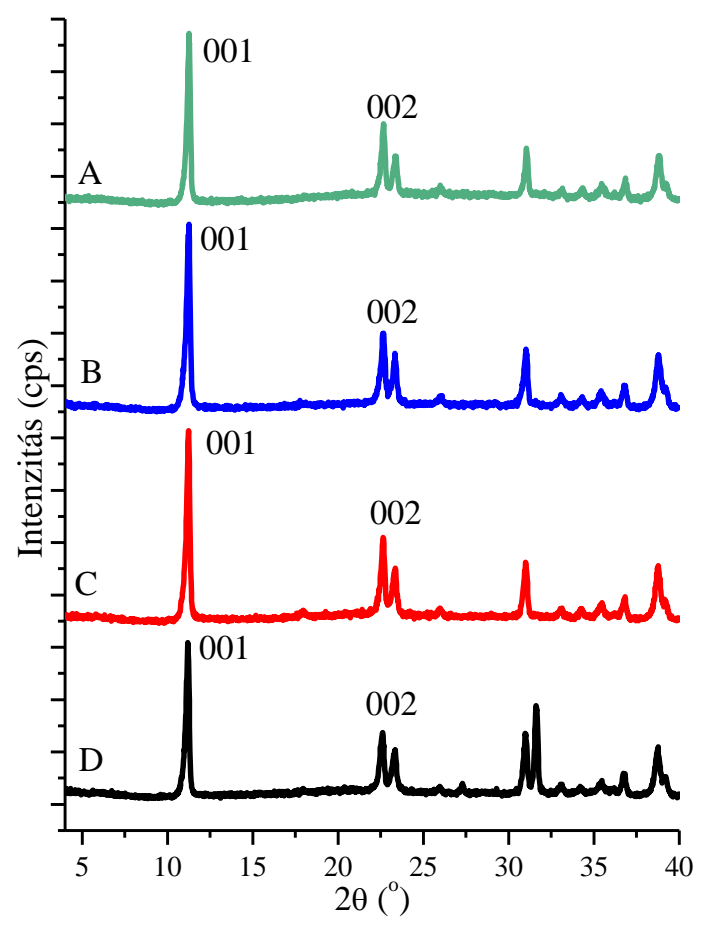

(a)

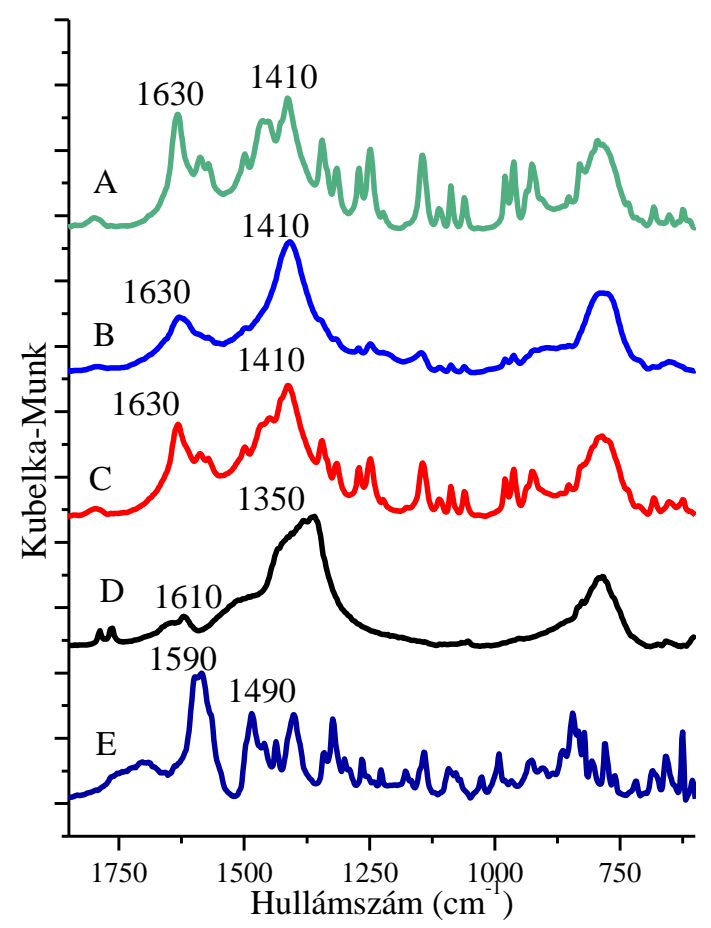

(b)

4. ábra: Hisztidináttartalmú CaAl-LDH-k röntgen diffraktogramjai (a) és IR spektrumai (b): A: $\mathrm{T}=25^{\circ} \mathrm{C} ; \mathrm{B}: \mathrm{T}=45^{\circ} \mathrm{C} ; \mathrm{C}: \mathrm{T}=60{ }^{\circ} \mathrm{C} ; \mathrm{D}: \mathrm{CaAl}-\mathrm{LDH} ; \mathrm{E}$ : Na-hisztidinát $\left(\mathrm{c}_{\mathrm{His}}=5 \cdot 10^{-2} \mathrm{M}\right.$; etanol; $\mathrm{pH}$ $=9,7)-$ a hömérséklet hatása.

$\mathrm{Az}$ első sikeresnek nevezhető szintéziseket a hisztidinát koncentrációjának csökkentésével sikerült elérni. Az 5/a ábrán azt láthatjuk, hogy az eredeti 001 és 002 reflexiók szétváltak két különböző reflexióra a hisztidinát koncentrációjának csökkentésére (5/a ábra, A és B diffraktogramok). Ez azt jelenti, hogy két különböző rétegtávolságú fázis található ezekben a kompozitokban. Ez az úgynevezett staging effektus. ${ }^{179}$ A legnagyobb rétegtávolság növekedést $1,0 \cdot 10^{-2} \mathrm{M}$ hisztidinkoncentráció esetén kaptuk (5/a ábra, $\mathrm{C}$ diffraktogram), és ebben az esetben már fázistiszta termékhez jutottunk. Az IR spektrumok (5/b ábra) is azt bizonyították, hogy a szerves anyag valóban beépült a rendszerbe. Az is 
látható, hogy az összes kompozit esetében megjelentek a hisztidinát karakterisztikus rezgései, valamint az eltolódott karboxilát rezgések (1620 és $1400 \mathrm{~cm}^{-1}$ ). Ugyanakkor az 5/b ábra C-vel jelölt görbén azt láthatjuk, hogy nagyon sávszegény a spektrum, vagyis valószínüsíthető, hogy a felületi megkötődés ebben az esetben háttérbe szorult. A tapasztaltak magyarázata az lehet, hogy a nagyobb aminosav koncentrációk tartományában már komolyan számolni kell a hisztidinát és a hozzáadott $\mathrm{NaOH}$-oldatból származó hidroxid ionok között fellépő kompetícióval. Ugyanis a hidroxid ionok is nagyon erősen képesek kötődni a rétegekhez, nem véletlen, hogy a karbonát ionok után közvetlenül következnek a liotróp sorban, ezért képesek megakadályozni a hisztidinát ionok beépülését. Így azok csak a felületen tudnak megkötődni. Ennek köszönhető az, hogy a nagyobb hisztidinátkoncentrációk esetén nem tapasztaltunk rétegtávolság növekedést. Ugyanakkor a kevesebb hozzáadott hisztidin esetén, kevesebb hidroxid ionra volt szükség a deprotonálódáshoz, így eljutottunk egy olyan koncentrációtartományba, ahol ez a versengés már kevésbé jelentős. Az is egyértelmünek tủnik, hogy a 001 '-vel jelölt fázis esetében hidroxid ionok épültek be a rétegek közé, és ezért csökkent a rétegtávolság. Mivel fázistiszta, egyértelműen megnövekedett rétegtávolsággal rendelkező kompozitot 1,0 $10^{-2}$ M koncentrációjú hisztidinoldat alkalmazása esetén kaptunk, ezért ezt a koncentrációt alkalmaztuk a továbbiakban. 


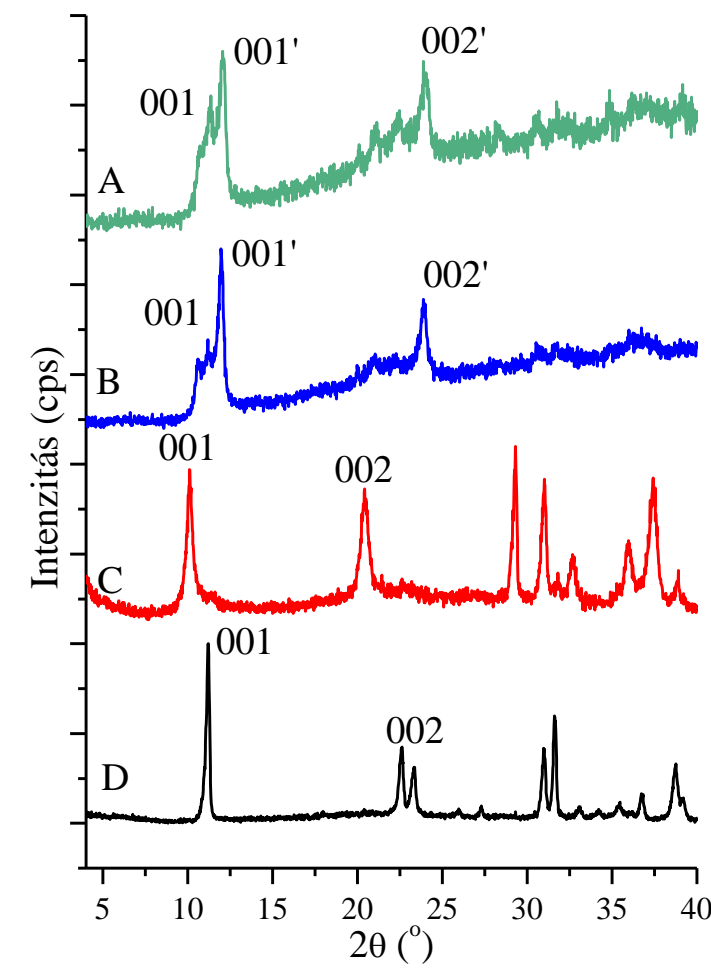

(a)

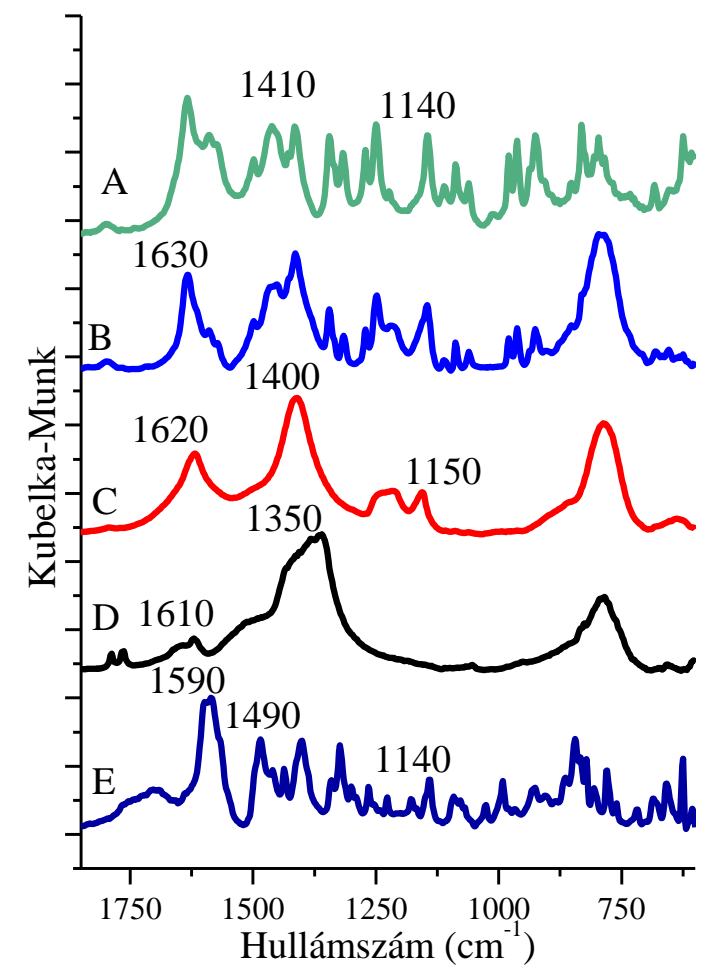

(b)

5. ábra: Hisztidináttartalmú CaAl-LDH-k röntgen diffraktogramjai (a) és IR spektrumai (b): $A: c_{\text {His }}$ $=3,5 \cdot 10^{-2} \mathrm{M}$; B: $\mathrm{c}_{\mathrm{His}}=2,0 \cdot 10^{-2} \mathrm{M} ; \mathrm{C}: \mathrm{c}_{\mathrm{His}}=1,0 \cdot 10^{-2} \mathrm{M}$; D: CaAl-LDH; E: Na-hisztidinát $\left(\mathrm{T}=25^{\circ} \mathrm{C}\right.$; etanol; $\mathrm{pH}=9,7)-\mathrm{az}$ aminosav koncentráció hatása.

A fentebb leírt érvelést egy kissé tovább finomítottuk, ugyanis kiderült, hogy egy minimális $\mathrm{pH}$ beállítására szükség van ahhoz, hogy kellő mennyiségű aminosav legyen anionos formában. Amennyiben az eddig alkalmazott 9,7-es pH-t 9,2-re csökkentettük, azt tapasztaltuk, hogy az LDH rétegtávolsága nem változott, vagyis nem sikerült a rétegek közé beépíteni az aminosav aniont (6/a ábra). Ugyanakkor az aminosav megkötődött az LDH-n (6/b ábra), azaz a nem anionos formában lévő hisztidin molekula adszorbeálódott az LDH felületére. Ha a pH 9,7 volt, akkor a már korábban látott eredményeket kaptuk, míg a pH-t 10,2-re emelve rétegtávolság csökkenést tapasztaltunk. Ekkor már az aminosav anionos formája kötődött meg a felületen, vagyis ebben az esetben már müködött a kompetíció. 


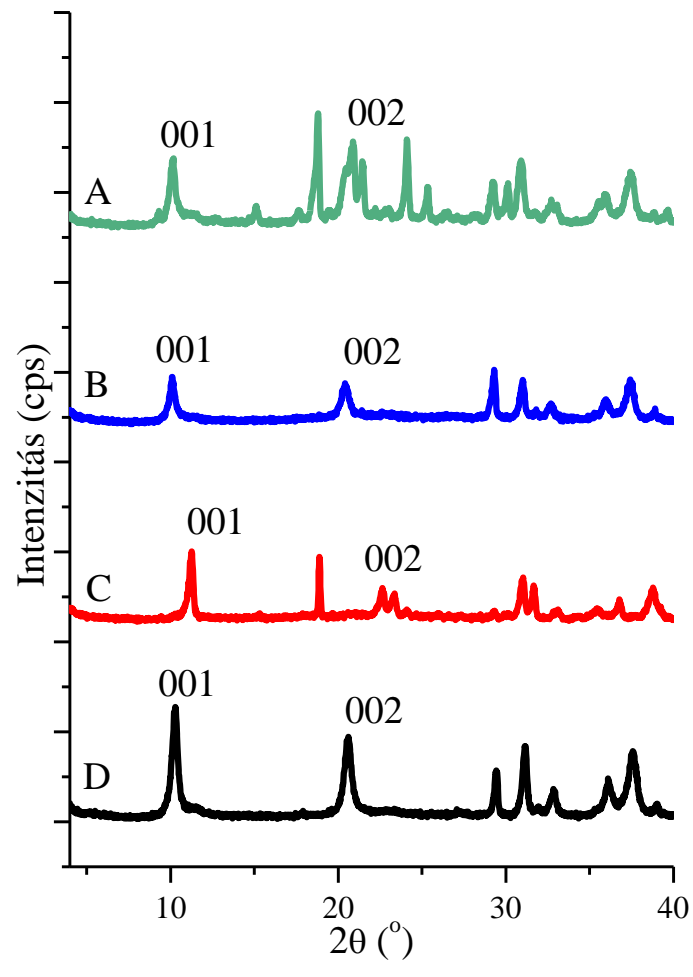

(a)

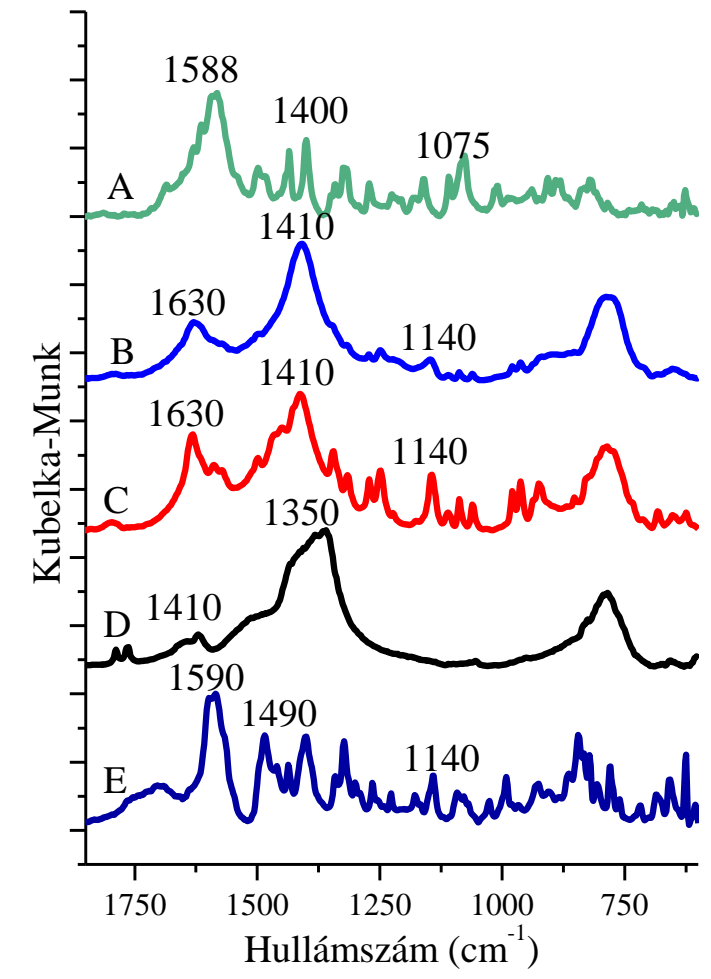

(b)

6. ábra: Hisztidináttartalmú CaAl-LDH-k röntgen diffraktogramjai (a) és IR spektrumai (b): A: $\mathrm{pH}$ $=9,2 ; \mathrm{B}: \mathrm{pH}=9,7 ; \mathrm{C}: \mathrm{pH}=10,2 ; \mathrm{D}: \mathrm{CaAl}-\mathrm{LDH} ; \mathrm{E}:$ Na-hisztidinát $\left(\mathrm{T}=25^{\circ} \mathrm{C}\right.$; etanol; $\mathrm{c}_{\mathrm{His}}=$ $\left.1,0 \times 10^{-2} \mathrm{M}\right)-\mathrm{a} \mathrm{pH}$ hatása.

A ciszteinát beépítése során nem sikerült lényegesnek mondható rétegtávolság növekedést detektálnunk. A 001 és 002 reflexiók helye nem változott, amint az látható a 7/a ábrán. Ugyanakkor a $\mathrm{pH}$ változtatásával ebben az esetben is jelentősen változtak az IR spektrumok (7/b ábra). 8,2-es pH-t alkalmazva az aminosav anionos formája kötődhetett meg a felületen, ezzel szemben 8,7-es valamint 9,2-es pH-n nagy valószínüséggel a hidroxid ionok mellett ciszteinát ionok is beépülhettek a rétegek közé, és/vagy kötődhettek meg a felületen. Az összes kompozit esetében biztosra vehető, hogy kialakult ionos kölcsönhatás a rétegek és az aminosav között, mivel a ciszteinát karboxilát rezgései eltolódtak (1520 és $1405 \mathrm{~cm}^{-1}$ ). Az optimális körülmények tehát ebben az esetben a következőek voltak: $\mathrm{pH}=8,7$, vizes etanol, $\mathrm{T}=35^{\circ} \mathrm{C} 2 \cdot 10^{-2} \mathrm{M}$ cisztein koncentráció. $\mathrm{Az}$ megemelt hőmérsékletre azért volt szükség, hogy a megfelelő mennyiségü aminosav feloldódjék. 


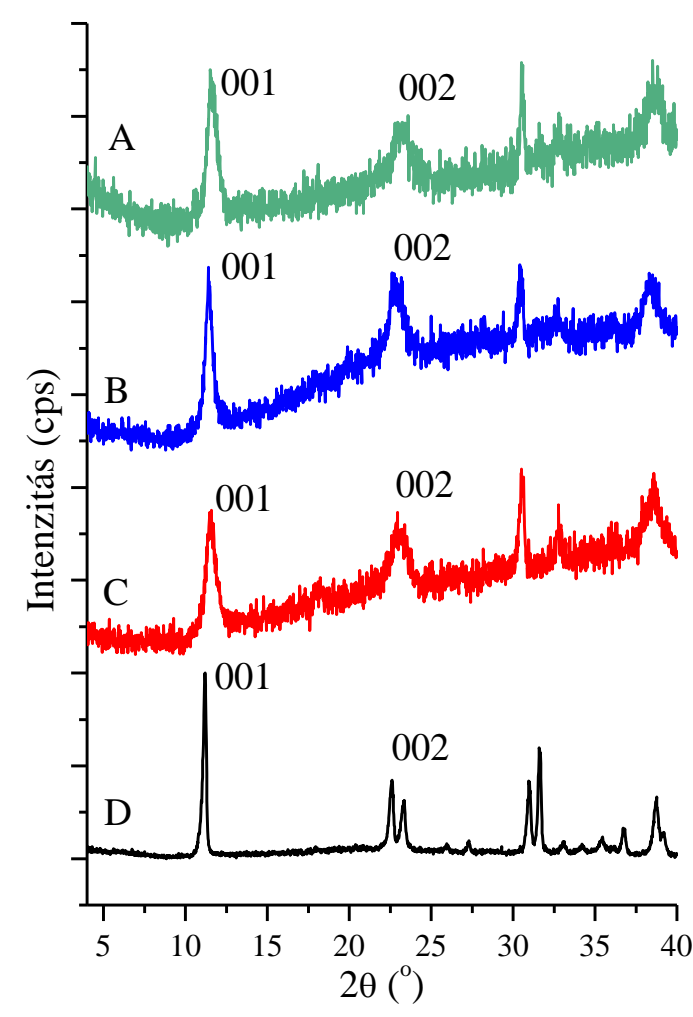

(a)

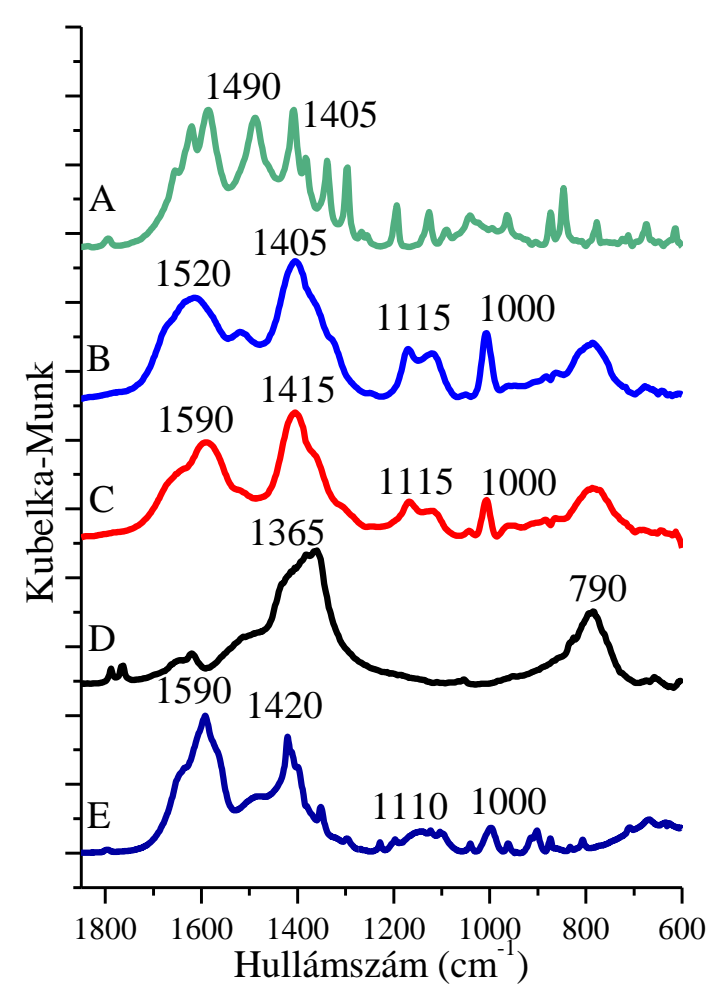

(b)

7. ábra: Ciszteináttartalmú CaAl-LDH-k röntgen diffraktogramjai (a) és IR spektrumai (b): $A: p H$ $=8,2 ; \mathrm{B}: \mathrm{pH}=8,7 ; \mathrm{C}: \mathrm{pH}=9,2 ; \mathrm{D}: \mathrm{CaAl}-\mathrm{LDH} ; \mathrm{E}:$ Na-ciszteinát; $\mathrm{c}_{\mathrm{Cys}}=2,0 \cdot 10^{-2} \mathrm{M}$; etanol; $\mathrm{T}=$ $35^{\circ} \mathrm{C}$.

A tirozinát anion beépítése esetében, a paraméterek optimalizálása után, a kiindulási LDH-ban mért 0,85 nm-es rétegtávolság 0,90 nm-re növekedett (8/a ábra), és az IR spektrumon megjelent az egyik eltolódott karboxilát rezgés $1510 \mathrm{~cm}^{-1}$-nél $(8 / \mathrm{b}$ ábra). Feltételezésünk szerint ez az aszimmetrikus rezgés, amelynek szimmetrikus párja beleolvadt az $1360 \mathrm{~cm}^{-1}$-nél látható sávba. Ez a sáv pedig az LDH felületén megkötődött karbonát ionokhoz, valamint a rétegközi térben megtalálható nitrát ionoktól származó vegyes rezgési sávkombinációhoz rendelhető. A tirozinát ion beépítése során alkalmazott, optimálisnak talált szintézisparaméterek a következőek voltak: lúgos vizes etanol, $25^{\circ} \mathrm{C}$, 2,0 $\cdot 10^{-2} \mathrm{M}$ koncentrációjú tirozinátoldat, 9,6-os $\mathrm{pH}$. 


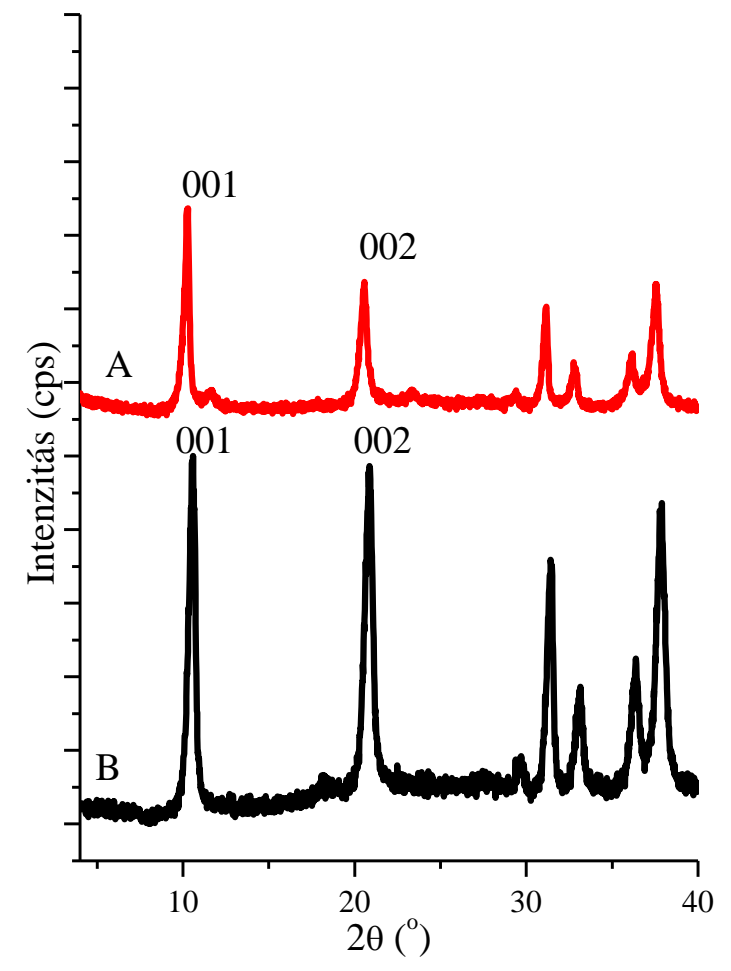

(a)

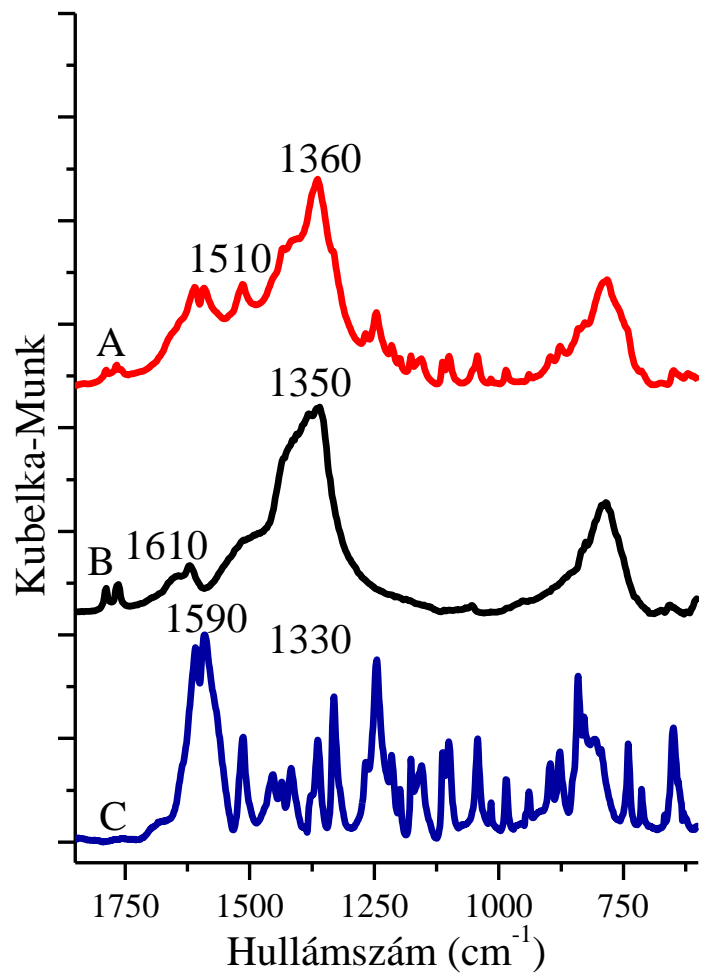

(b)

8. ábra: Tirozináttartalmú CaAl-LDH-k röntgen diffraktogramjai (a) és IR spektrumai (b): $\mathrm{A}: \mathrm{pH}=$ 9,6, B: CaAl-LDH, C: Na-tirozinát; $\mathrm{c}_{\mathrm{Tyr}}=2,0 \cdot 10^{-2} \mathrm{M}$; vizes etanol; $\mathrm{T}=25^{\circ} \mathrm{C}$.

\section{Komplexképzés a rétegek között}

A Mn(II)-hisztidinát komplex rétegközi kialakítását szolgáló kísérleteinkben is kipróbáltuk mindhárom oldószert, illetve oldószerelegyet, de egyik esetben sem kaptunk rétegtávolság növekedést. Sőt, amennyiben összevetjük a hisztidinnel sikeresen interkalált kompozit rétegtávolságával, akkor a rétegtávolság csökkenését tapasztaltuk (9/a ábra). Vélhetően az aminosav kimosódott a rendszerből. Ezt bizonyították az IR spektrumok is, amelyeken nem jelent meg egyetlen, az aminosavhoz köthető rezgés sem (9/b ábra). Ez alól csupán a vizes etanolban készült kompozit a kivétel, amelynek spektrumában számos hisztidinhez köthető csúcsot detektálhattunk. Így a vizes etanolt választottuk oldószernek. 


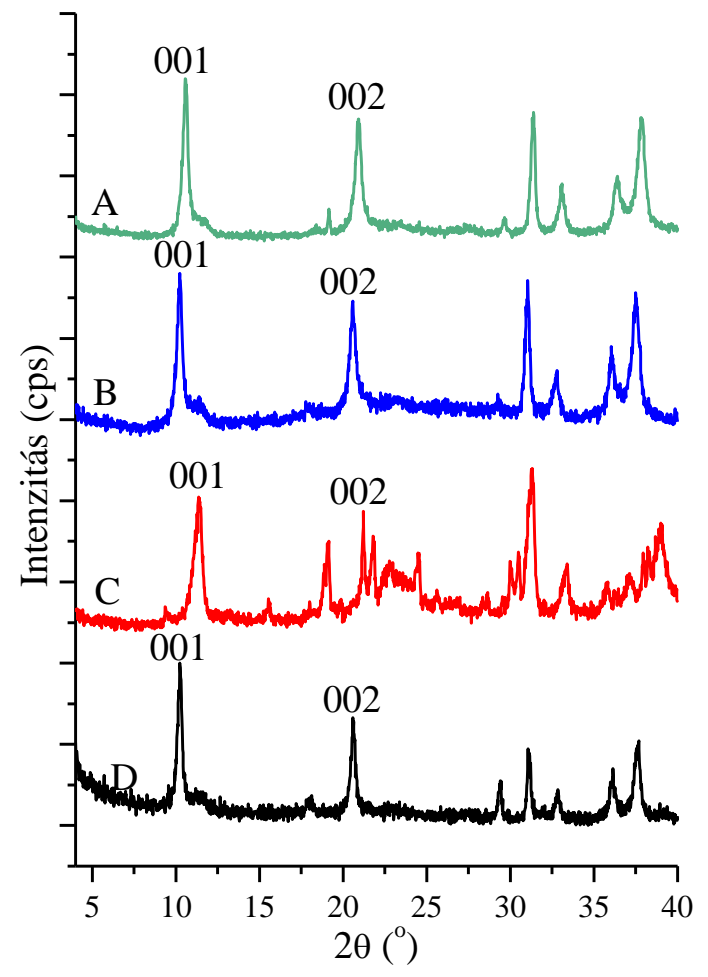

(a)

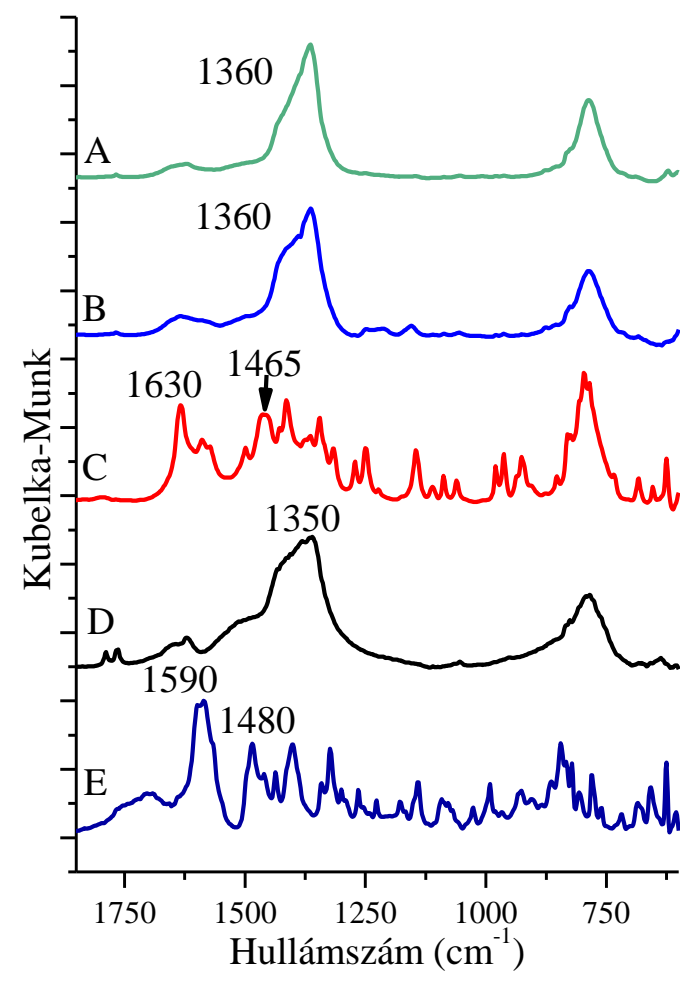

(b)

9. ábra: CaAl-Mn(II)-hisztidinát-LDH kompozitok röntgen diffraktogramjai (a) és IR spektrumai (b): A: víz; B: vizes aceton; C: vizes etanol; D: CaAl-LDH; E: Na-hisztidinát (His:Mn(II) = 2:1, pH $=7,0)-$ az oldószer hatása.

A pH növelésével el lehetett érni, hogy az eredeti rétegtávolsághoz (sikeres hisztidinát beépítése esetén) nagyban hasonlító távolság alakuljon ki a mangánsó hozzáadása után (10/a ábra). Ezt a 8,5-es pH-n szintetizált minta esetében sikerült megvalósítani. Ennek a kompozitnak az IR spektrumában megmaradtak az eltolódott karboxilát rezgések (1615 és $1415 \mathrm{~cm}^{-1}$ ). Ugyanakkor megjelent egy új sáv $1510 \mathrm{~cm}^{-1}$-nél, amely feltehetően az egyik karboxilát oxigénhez köthetö, amelyhez $\mathrm{Mn}$ (II) ion koordinálódott (10/b ábra). Amint azt már említettük, alacsonyabb, 7,5-es pH-n az aminosav kimosódott a rendszerböl, és a komplex oldatban maradt, míg 9,5-es pH-n a komplex felületi megkötődése vált dominánssá. 


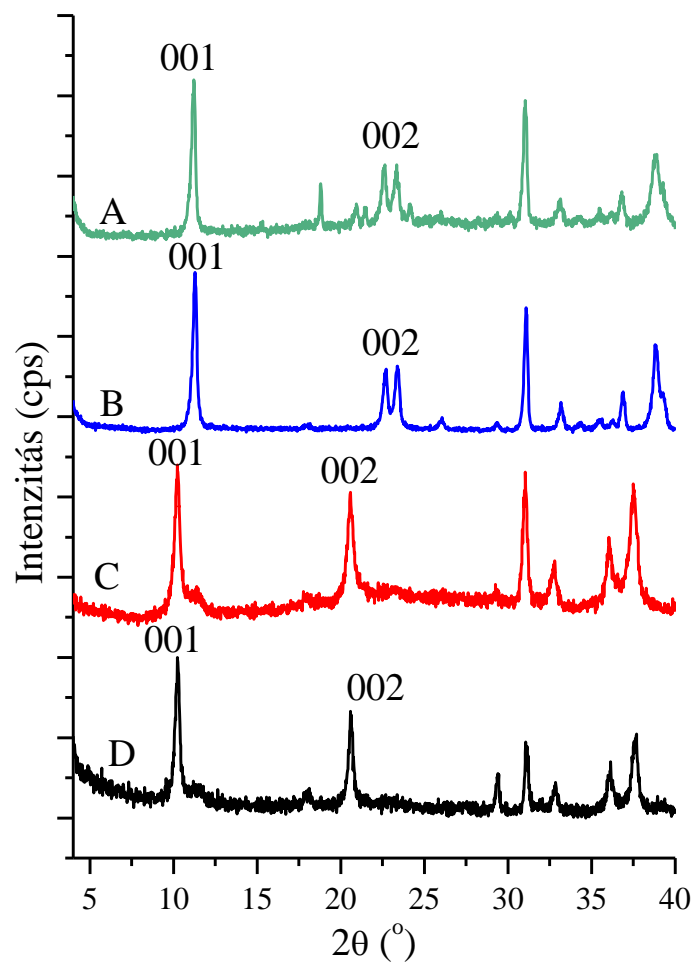

(a)

10. ábra: CaAl-Mn(II)-hisztidinát-LDH kompozitok röntgen diffraktogramjai (a) és IR spektrumai (b): $\mathrm{A}: \mathrm{pH}=9,5 ; \mathrm{B}: \mathrm{pH}=8,5 ; \mathrm{C}: \mathrm{pH}=7,5 ; \mathrm{D}: \mathrm{CaAl}-\mathrm{LDH}$; E: Na-hisztidinát (His:Mn(II) = 2:1; etanol) - a pH hatása.

A aminosav/fém ion arány megváltoztatásával tovább akartuk javítani a beépülés sikerességét, de 4:1 vagy 6:1 arányú komplexek esetén is kimosódást tapasztaltunk. A rétegtávolságok $0,78 \mathrm{~nm}$ körülire csökkentek (11/a ábra), az IR spektrumokból pedig eltüntek az aminosavra jellemző sávok (11/b ábra). 

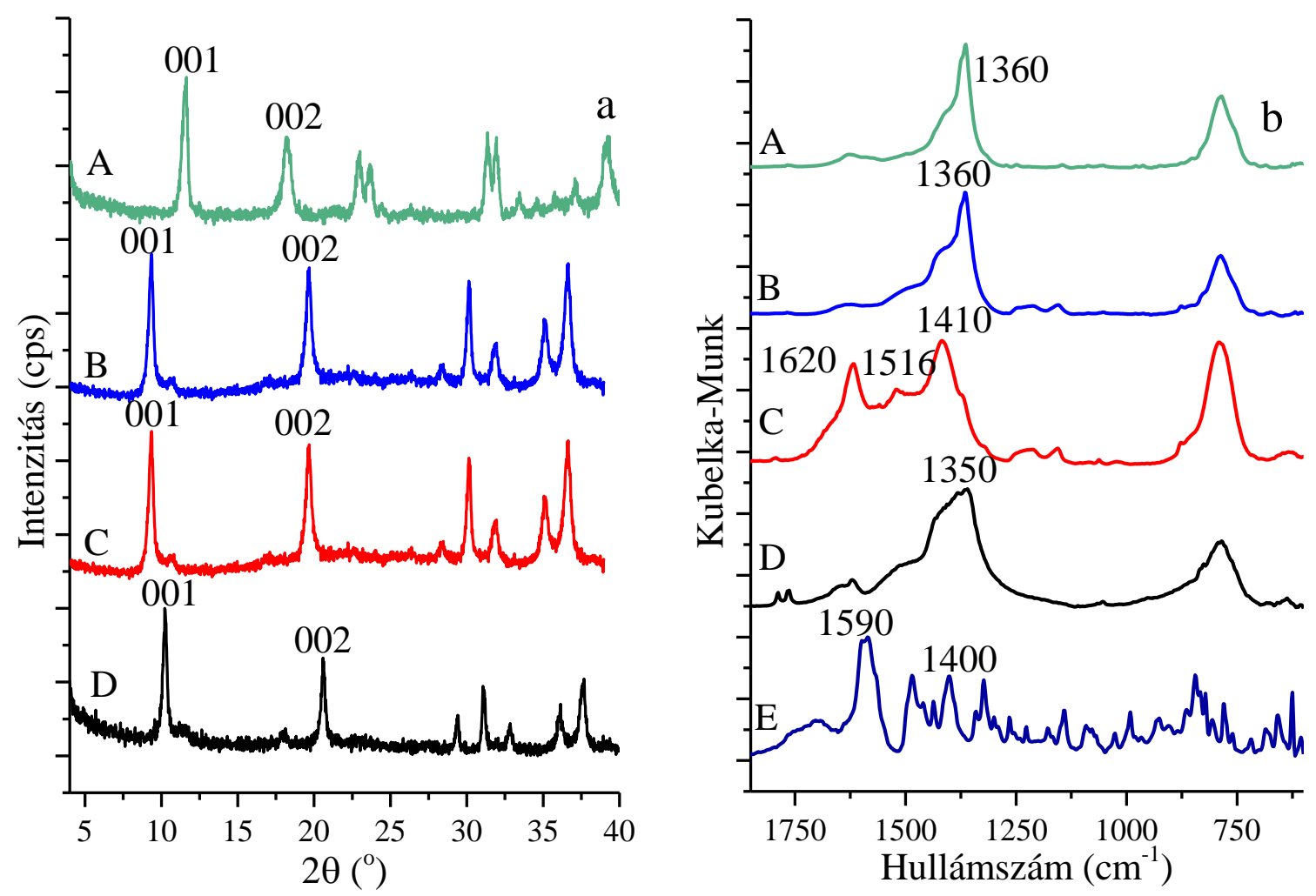

11. ábra: $\mathrm{CaAl}-\mathrm{Mn}$ (II)-hisztidinát-LDH kompozitok röntgen diffraktogramjai (a) és IR spektrumai (b): A: His:Mn(II) = 6:1; B: His:Mn(II) = 4:1; C: His:Mn(II) = 2:1; D: CaAl-LDH; E: Nahisztidinát $(\mathrm{pH}=8,5$; etanol) - az aminosav/fém ion arány hatása.

A Mn(II)-tirozinát komplex kiépítésekor is a vizes etanol volt a megfelelő választás. Alkalmazása esetén $0,90 \mathrm{~nm}$-es rétegtávolsághoz tartozó $2 \theta$ értéket mértünk (12/a ábra), és a rezgési spektrumon megjelentek az eltolódott karboxilát rezgések (1570, 1513 és 1400 $\left.\mathrm{cm}^{-1}\right)(12 / \mathrm{b}$ ábra). Ezek a rezgések a réteghez kötődött, valamint a koordinációban résztvevő karboxilát oxigénekhez rendelhetők. Amennyiben azonban víz volt az oldószer, akkor a tirozinát olyan nagy mennyiségben adszorbeálódott az LDH felületére, hogy elfedte annak jeleit. Ez nem csupán az IR spektrumokon, hanem a röntgen diffraktogramokon is megfigyelhető volt. 


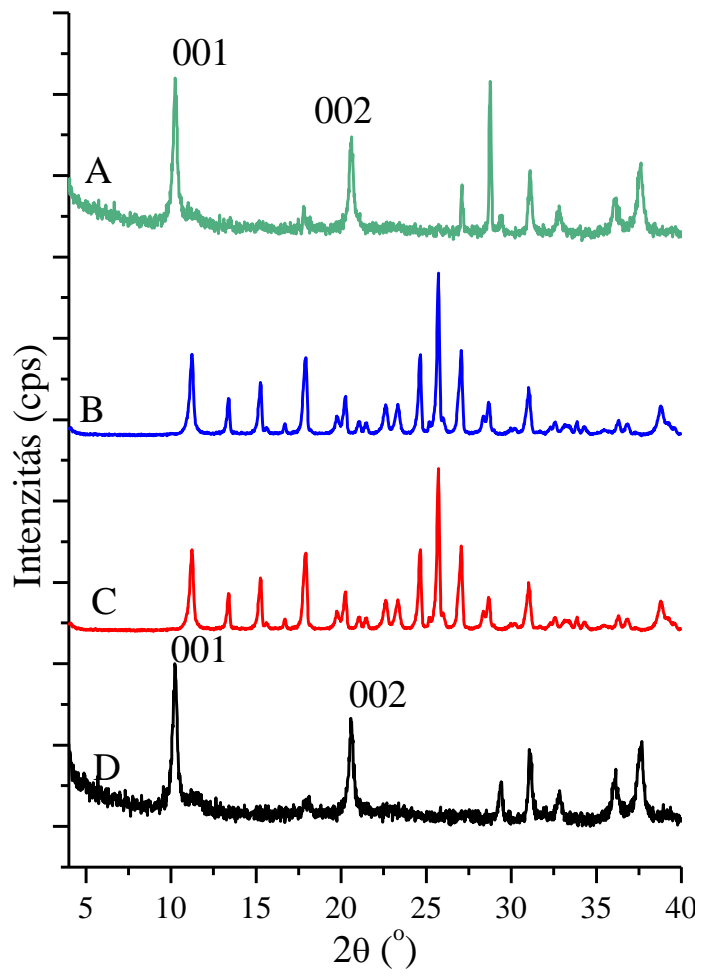

(a)

12. ábra: CaAl-Mn(II)-tirozinát-LDH kompozitok röntgen diffraktogramjai (a) és IR spektrumai (b): A: víz; B: vizes etanol; C: Na-tirozinát; D: CaAl-LDH (Tyr:Mn(II) = 4:1; $\mathrm{pH}=8,0$ ).

A Mn(II)-ciszteinát komplex kiépítése az LDH rétegközi terében ezzel a módszerrel sikertelen volt.

\subsubsection{A $B$ módszer}

A Mn(II)-ciszteinát, illetve a Mn(II)-tirozinát komplex anionos formáit sikerült ezzel a módszerrel beépíteni a rétegközi térbe, míg a $\mathrm{Mn}$ (II)-hisztidinát komplex beépítése sikertelen volt. A szintézismódszert és az optimális paraméterek megtalálását a Mn(II)ciszteinát beépítésén mutatjuk be.

Az első lépés itt is a megfelelő oldószer kiválasztása volt. A kompozitok diffraktogramjai egyértelmüvé tették, hogy az etanol/víz elegy a megfelelő választás (13/a ábra). A lúgos vizes etanolban készült kompozit esetében az eredeti 0,85 nm-es rétegtávolság 0,91 nm-re növekedett - ez a sikeres interkaláció egyértelmü bizonyítéka. Az idetartozó IR spektrumon (13/b ábra, C spektrum) látható is olyan sáv, amely a szerves anyag jelenlétét igazolja. 


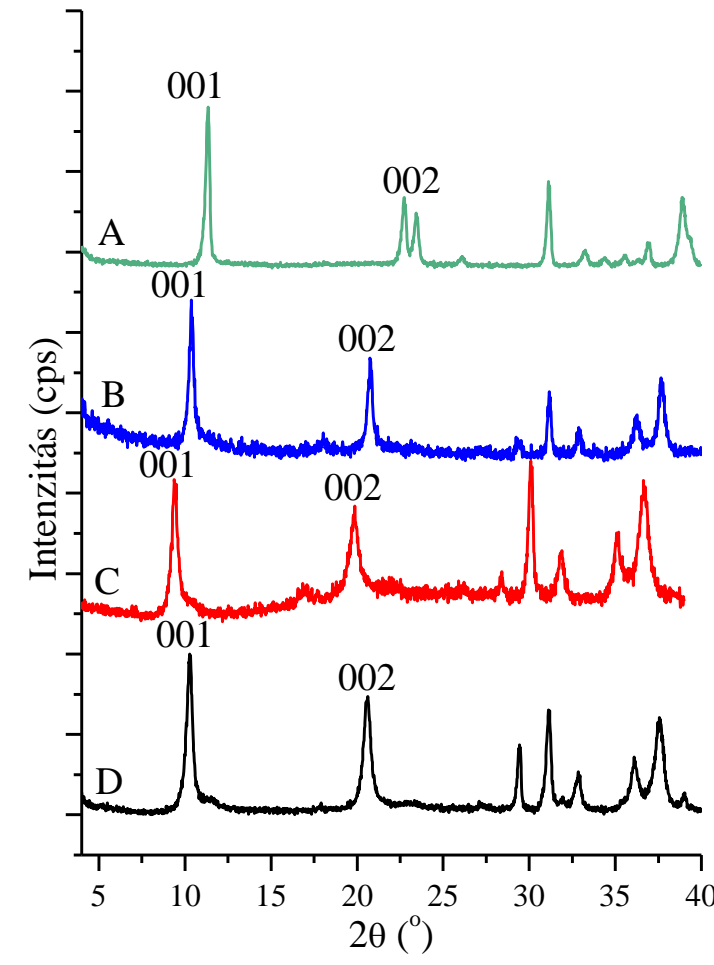

(a)

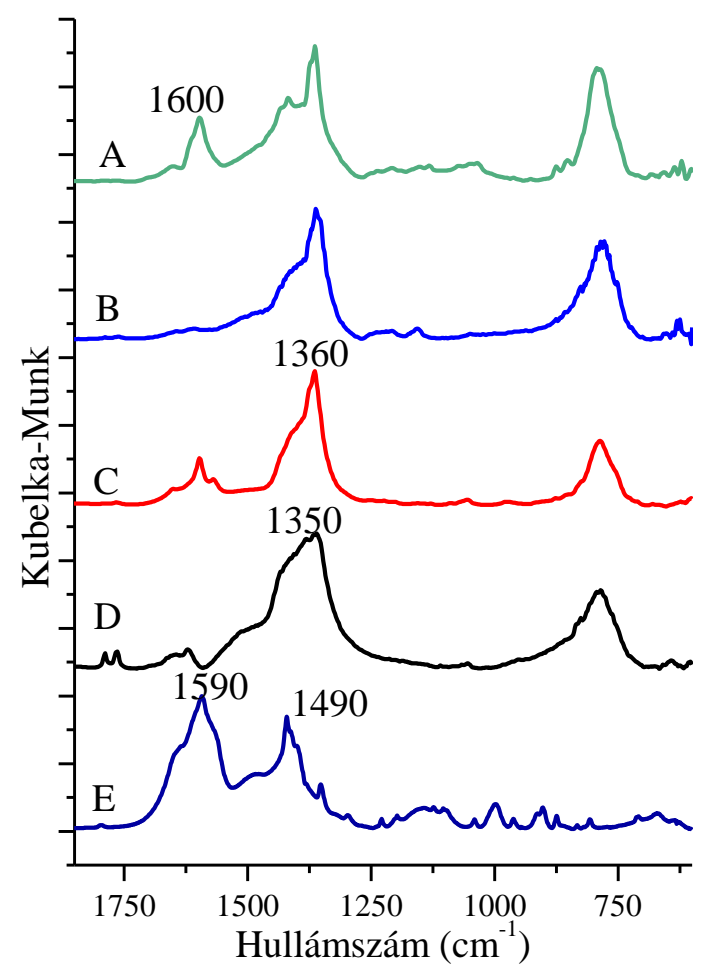

(b)

13. ábra: $\mathrm{Mn}$ (II)-ciszteinát-CaAl-LDH kompozitok röntgen diffraktogramjai (a) és IR spektrumai (b): A: víz; B: vizes aceton; C: vizes etanol; D: CaAl-LDH; E: Na-ciszteinát $\left(\mathrm{T}=25^{\circ} \mathrm{C}\right.$; $\mathrm{c}_{\mathrm{Cys}}=$ $\left.1,0 \times 10^{-2} \mathrm{M} ; \mathrm{pH}=9,0\right)-$ az oldószer hatása.

Az interkalálás $\mathrm{pH}$-ját 8,5-re csökkentve a rétegtávolság még $0,01 \mathrm{~nm}-\mathrm{t}$ nött, a $\mathrm{pH}$ 9,5-re növelése viszont a rétegtávolság csökkenésével, azaz a komplex anion interkalációjának elmaradásával járt.

\subsection{A sikeresen kiépített interkalált szerkezetek}

A többi fém ion esetén is végigjártuk az előbbiekben részletezett optimalizálási lépéseket. A két alkalmazott módszer valamelyike mindig sikerre vezetett. A Mn(II)tirozinát komplex interkalálása mindkét módszerrel sikeres volt. Itt a katalitikus vizsgálatokhoz azt a mintát választottuk, amelyben dominánsan a rétegek között volt a komplex anionos formája.

A sikeresen beépítéshez szükséges paramétereket a 3. táblázatban mutatjuk be. 
3. táblázat: A sikeres előállításhoz szükséges paraméterek.

\begin{tabular}{ccccccc}
\hline Kompozit & Módszer & $\begin{array}{c}\mathrm{c}_{\text {aminosav }} \\
\left(\mathrm{mmol}_{\mathrm{dm}}{ }^{3}\right)\end{array}$ & $\begin{array}{c}\text { Aminosav/fém ion } \\
\text { arány }\end{array}$ & $\mathrm{pH}$ & $\begin{array}{c}\text { Hömérséklet } \\
\left({ }^{\circ} \mathrm{C}\right)\end{array}$ & $\begin{array}{c}\text { Oldószer } \\
(1: 10)\end{array}$ \\
\hline $\mathrm{Mn}(\mathrm{II})-\mathrm{His}$ & $\mathrm{A}$ & 10 & 2 & 8,5 & 25 & víz:etanol \\
$\mathrm{Mn}(\mathrm{II})-\mathrm{Cys}$ & $\mathrm{B}$ & 20 & 4 & 8,5 & 25 & víz:etanol \\
$\mathrm{Mn}(\mathrm{II})-\mathrm{Tyr}$ & $\mathrm{B}$ & 20 & 4 & 8,0 & 25 & víz:etanol \\
\hline $\mathrm{Cu}(\mathrm{II})-\mathrm{His}$ & $\mathrm{B}$ & 10 & 4 & 8,0 & 25 & víz:etanol \\
$\mathrm{Cu}(\mathrm{II})-\mathrm{Cys}$ & $\mathrm{A}$ & 20 & 4 & 8,0 & 35 & víz:etanol \\
$\mathrm{Cu}(\mathrm{II})-\mathrm{Tyr}$ & $\mathrm{B}$ & 20 & 4 & 8,0 & 35 & víz:etanol \\
\hline $\mathrm{Ni}(\mathrm{II})-\mathrm{His}$ & $\mathrm{B}$ & 10 & 2 & 7,0 & 25 & víz:etanol \\
$\mathrm{Ni}(\mathrm{II})-\mathrm{Cys}$ & $\mathrm{A}$ & 20 & 4 & 7,0 & 35 & víz:etanol \\
$\mathrm{Ni}(\mathrm{II})-\mathrm{Tyr}$ & $\mathrm{B}$ & 10 & 4 & 7,5 & 35 & víz:etanol \\
\hline $\mathrm{Fe}(\mathrm{III})-H i s$ & $\mathrm{~B}$ & 20 & 4 & 8,0 & 25 & víz:etanol \\
$\mathrm{Fe}(\mathrm{III})-\mathrm{Cys}$ & $\mathrm{A}$ & 20 & 4 & 7,0 & 35 & víz:etanol \\
$\mathrm{Fe}(\mathrm{III})-\mathrm{Tyr}$ & $\mathrm{B}$ & 10 & 4 & 8,0 & 35 & víz:etanol \\
\hline
\end{tabular}

Már eddig is ezt tettük, és továbbiakban is jelezni fogjuk az írásmóddal azt, hogy a kompozitot milyen módszerrel alakítottuk ki. Az A módszerrel előállított írásmódja CaAlfém ion-aminosav anion-LDH, $B$ módszerrel előállítotté pedig fém ion-aminosav anionCaAl-LDH.

A katalitikus vizsgálatokhoz felhasznált CaAl-Mn(II)-ciszteinát-LDH kompozitot az ATR-IR, illetve a PA-IR spektrumok összehasonlításával választottuk ki. Az ATR-IR spektrum dominánsan olyan rezgési sávokat tartalmaz, amelyek az LDH szerkezetéhez kapcsolódnak. $1420 \mathrm{~cm}^{-1}$-nél az interkalált nitrát ion vegyértékrezgése, $1350 \mathrm{~cm}^{-1}$-nél pedig a felületen kötött karbonát ionok vegyértékrezgése jelenik meg. A $750 \mathrm{~cm}^{-1}$ körül látható rezgési sáv az Al-O kötéshez tartozó vegyértékrezgés (14/a ábra, A spektrum). Ezen kívül nem jelent meg más, szerves anion jelenlétére utaló sáv, csupán az $1600 \mathrm{~cm}^{-1}$ körül egy kis intenzitású sáv, amely valószínüleg a karboxilát ion egyik rezgése. A másik valószínűleg beleolvadt az LDH-hoz tartozó, az előbb említett, LDH-hoz tartozó rezgésekbe. Vagyis az LDH felületén legfeljebb minimális mennyiségben kötődött meg az aminosav komplex anion. Ezzel szemben a PA-IR spektrumon (19/b ábra, A spektrum) számos új rezgést láthatunk. Ezek közül az eltolódott aszimmetrikus karboxilát rezgést lehetett azonosítani $1630 \mathrm{~cm}^{-1}$ körül. 1500 és $1440 \mathrm{~cm}^{-1}$ körül megjelenő sávok lehetnek a szimmetrikus karboxilát rezgések. A többes szám nem véletlen, vélhetően az egyik rezgés az ionos kölcsönhatás miatt tolódott el, a másik eltolódott rezgés feltehetően a komplexálás bizonyítéka. Egyéb kis intenzitású rezgések is megtalálhatók, de ezek azonosítása nehézkes. 


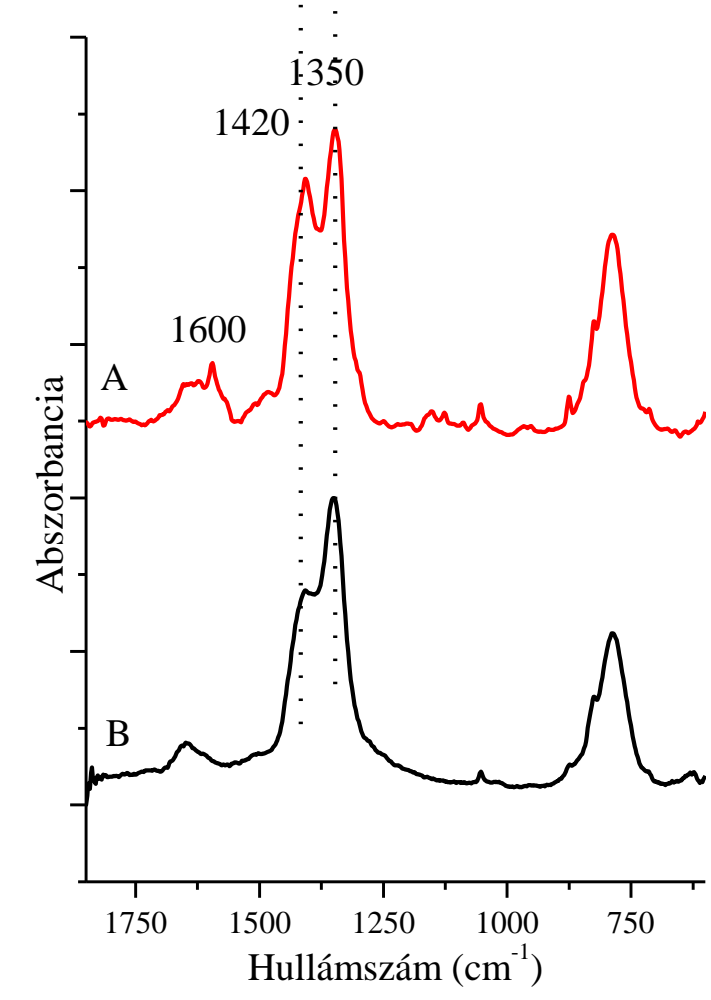

(a)

14. ábra: A CaAl-Mn(II)-ciszteinát-LDH (A) és a CaAl-LDH ATR-IR (a) és PA-IR spektrumai (b).

A SEM felvételek azt jelzik, hogy az LDH-ra jellemző morfológia megmaradt az interkalálás után. A hatszöges, lapkás elrendeződés valamint kristályos szerkezetre jellemző élek mind láthatóak (20. ábra).

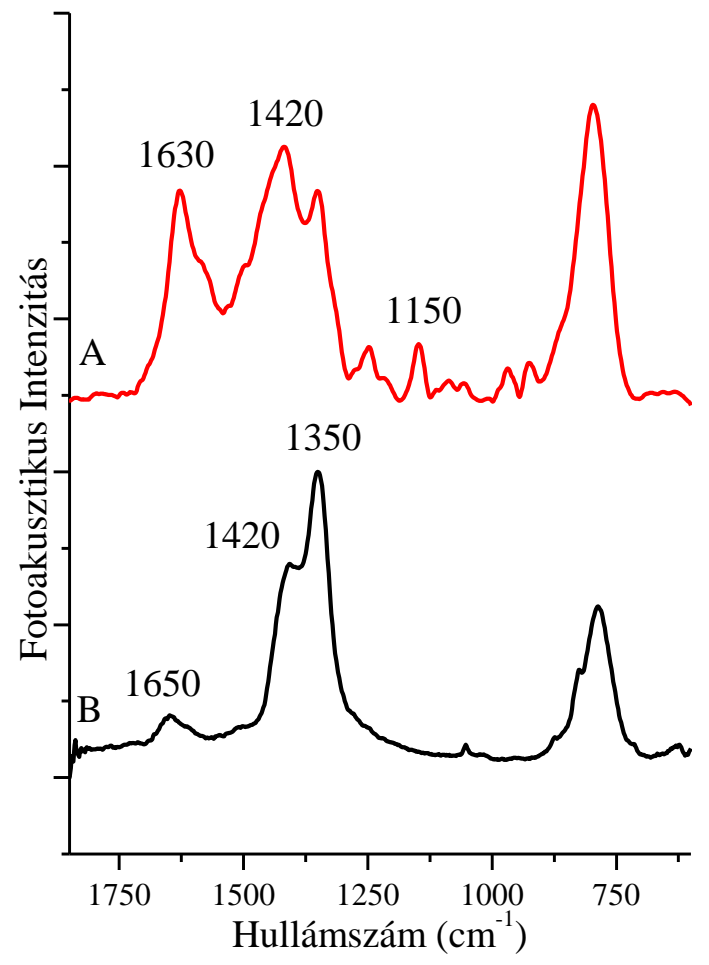

(b) 

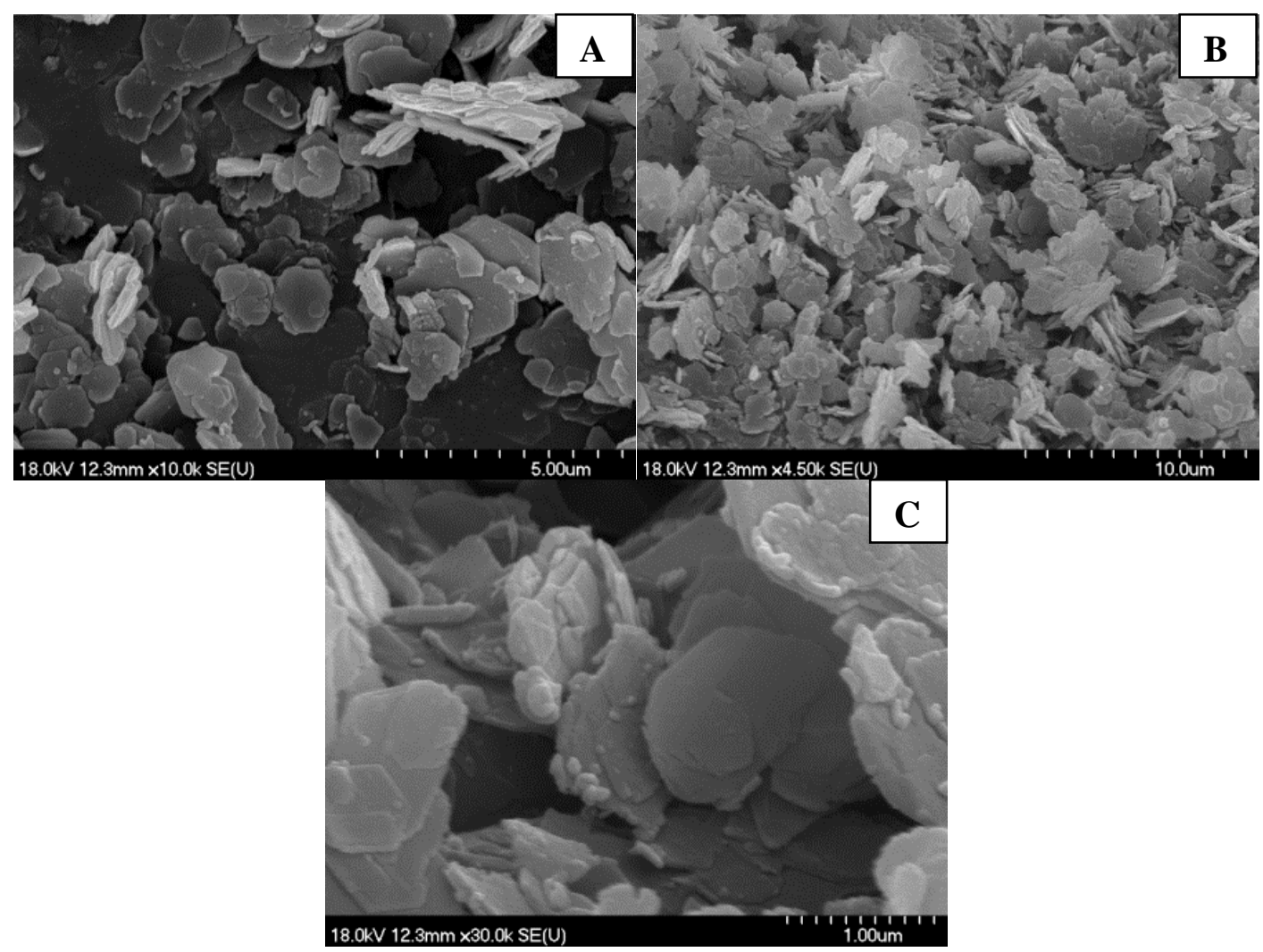

20. ábra: Mn(II)-aminosav-LDH kompozitok SEM felvételei: A: Mn(II)-tirozinát-CaAl-LDH; B: Mn(II)-ciszteinát-CaAl-LDH; C: CaAl-Mn(II)-hisztidinát-LDH.

A rezet tartalmazó kompozitok bemutatásával folytatjuk az eredmények tárgyalását.

A $\mathrm{Cu}(\mathrm{II})$-tirozinát rétegközi kiépítésére a $B$ módszer bizonyult alkalmasnak, lúgos vizes $(\mathrm{pH}=8,0)$ etanol és 4:1 nominális aminosav/fém ion arány mellett. A kompozit diffraktogramja meglepő volt abból a szempontból, hogy a rétegtávolság nagymértékben növekedett, a kiindulási 0,85 nm-röl 1,1 nm-re (21. ábra, A diffraktogram). Ez azt jelenti, hogy a tirozinát vagy több rétegben épült be, vagy úgy, hogy a fenilgyürü síkja merőleges az LDH rétegekre. ${ }^{180}$ Itt meg kell azonban jegyezni, hogy ebben az esetben nem sikerült fázistiszta LDH-t előállítani, mert megmaradt az eredeti rétegtávolsággal rendelkező LDH fázis is (staging effektus). A minta ATR-IR spektruma (22/a ábra, A spektrum) nem mutatott szerves anyag jelenlétére utaló jelet, ezzel szemben számos új, a tirozináthoz köthető rezgés található a PA-IR spektrumban (22/b ábra, A spektrum). 


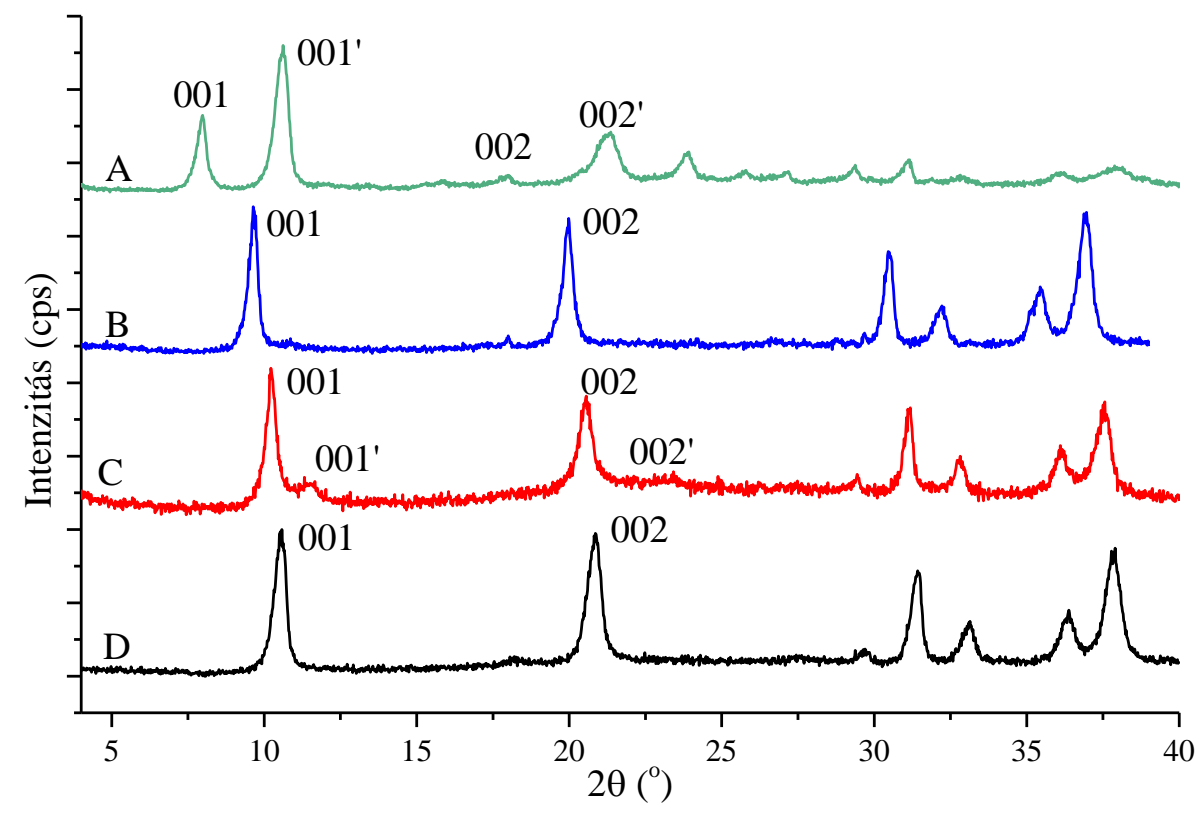

21. ábra: $\mathrm{Cu}(\mathrm{II})$-aminosav-LDH kompozitok röntgen diffraktogramjai: $\mathrm{A}: \mathrm{Cu}(\mathrm{II})$-tirozinát-CaAlLDH; B: CaAl-Cu(II)-ciszteinát-LDH; C: Cu(II)-hisztidinát-CaAl-LDH; D: CaAl-LDH.

A hisztidinát ligandumú komplex, hasonlóan a tirozináttartalmúhoz, a $B$ módszerrel készült és a szintézisparaméterek is ugyanolyanok voltak. Ugyanakkor a rétegtávolság nem változott, megmaradt 0,85 nm-nek (21. ábra, C diffraktogram). Erre kétféle magyarázat adható. Elképzelhető, hogy az LDH felületén kötődött meg a komplex, vagy a hisztidinát az imidazolátgyürủ síkjában „feküdt be” a rétegek közé. ${ }^{181}$ Az ATR-IR spektrum alapján az első feltételezés elvethető (22/a ábra, C spektrum), mivel szerves anyagra utaló rezgések nem jelentek meg, így a második állítás a valószínűbb, ugyanis az interkalálás sikerességét a PA-IR spektrum alátámasztja (22/b ábra, C spektrum). 

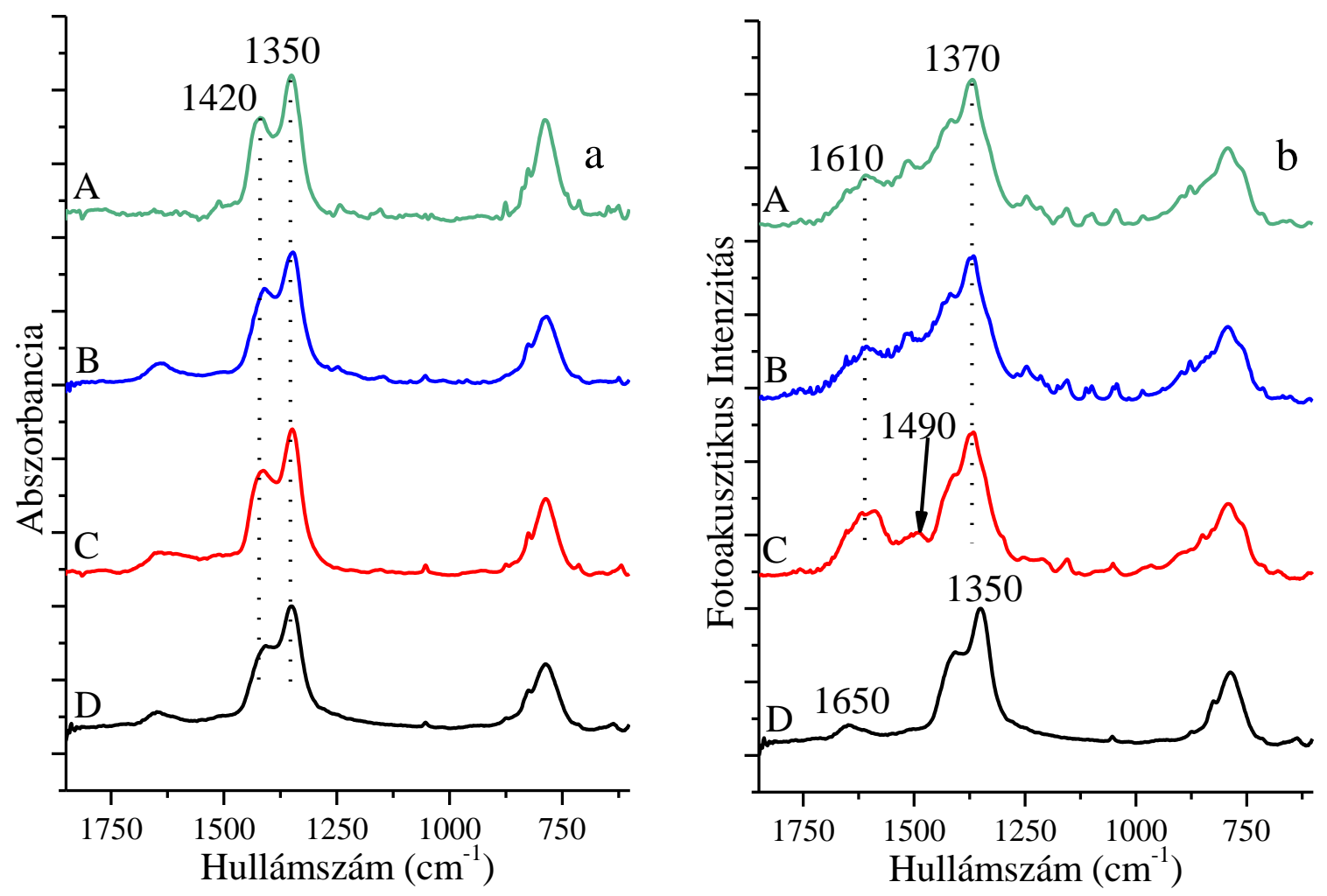

22. ábra: $\mathrm{Cu}$ (II)-aminosav-LDH kompozitok ATR-IR (a) és PA-IR spektrumai (b): $\mathrm{A}$ : $\mathrm{Cu}$ (II)tirozinát-CaAl-LDH, B: CaAl-Cu(II)-ciszteinát-LDH, C: Cu(II)-hisztidinát-CaAl-LDH, D: CaAlLDH.

A ciszteinátot tartalmazó minta esetében is ugyanezeket a szintézisparamétereket kellett beállítani a sikeres interkaláláshoz, ám itt az A módszer alkalmazása bizonyult sikeresnek. Jelentős rétegtávolság növekedés, $(0,85 \mathrm{~nm}$-ről $0,95 \mathrm{~nm}$-re), következett be (21. ábra, B diffraktogram). Az ATR-IR és PA-IR spektrumok összehasonlítása ismét azt igazolta, hogy nem kötődött meg jelentős mennyiségü aminosav vagy aminosav komplex az LDH felületén. 

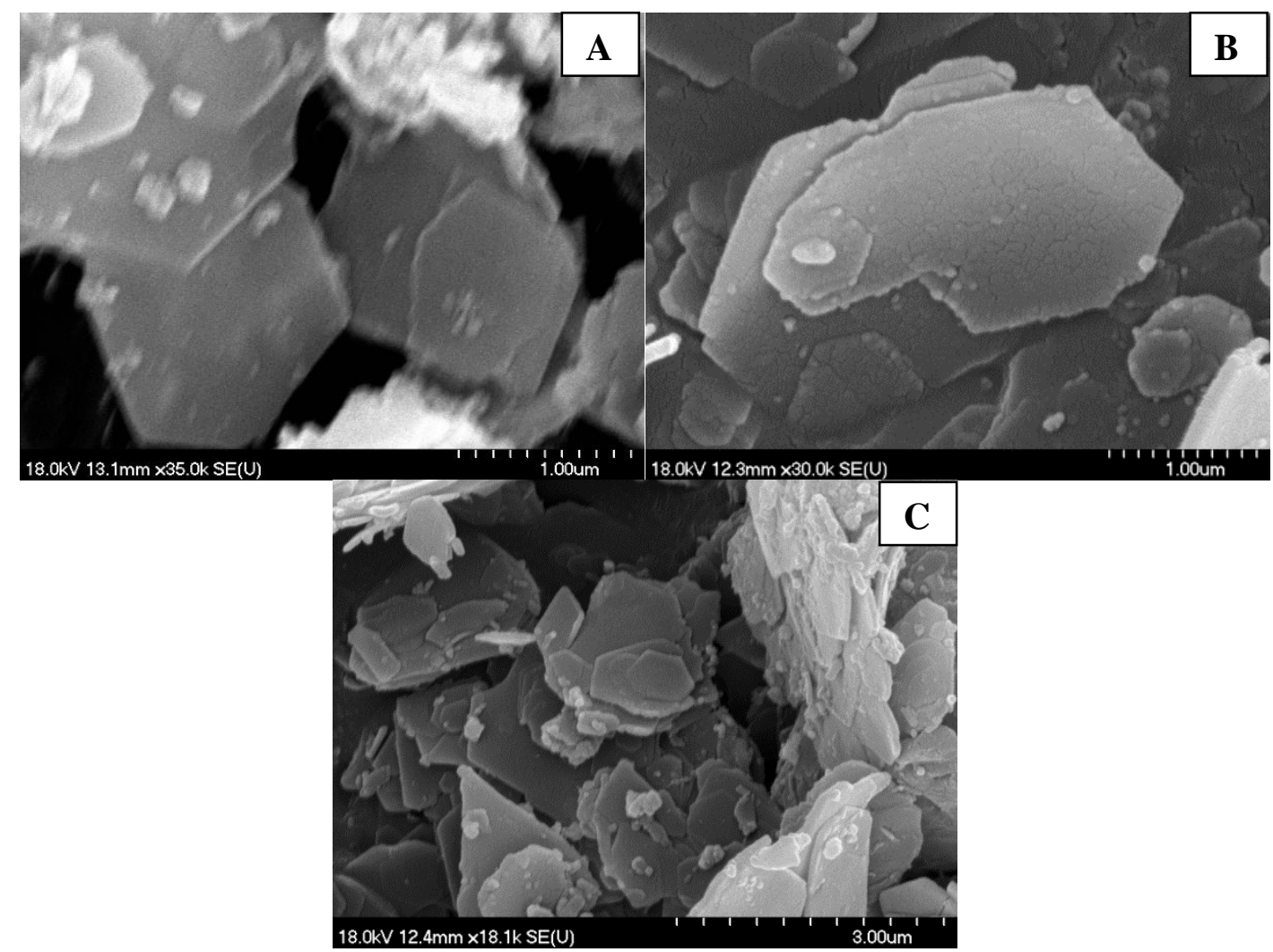

23. ábra: $\mathrm{Cu}(\mathrm{II})-$ aminosav-LDH kompozitok SEM felvételei: $\mathrm{A}$ : $\mathrm{Cu}(\mathrm{II})$-tirozinát-CaAl-LDH; $\mathrm{B}$ : CaAl-Cu(II)-ciszteinát-LDH; C: Cu(II)-hisztidinát-CaAl-LDH.

A SEM felvételek minden kétséget kizáróan bizonyítják, hogy az interkalálás hatására nem károsodott az LDH szerkezete, megmaradt a jellegzetes hexagonális elrendeződés (23. ábra). Az EDX felvétel szerint a réz és a kén eloszlása egyenletes a ciszteinát ligandumú kompozitban (24. ábra).

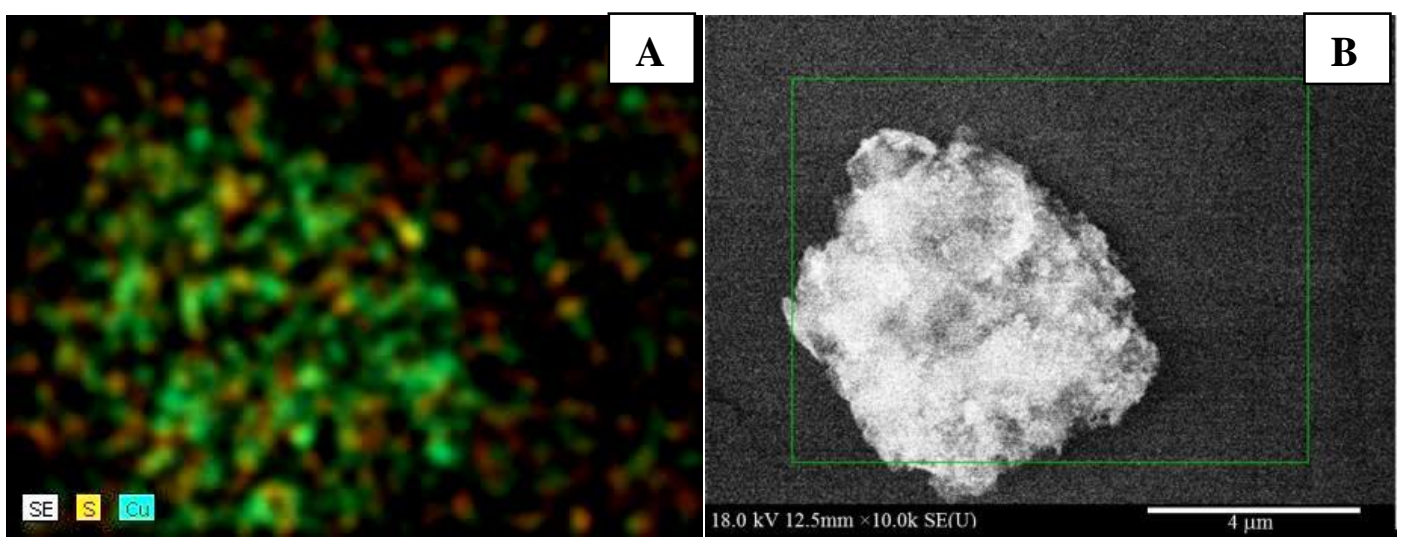

24. ábra: $\mathrm{CaAl}-\mathrm{Cu}(\mathrm{II})$-ciszteinát-LDH kompozit EDX elemtérképe: $\mathrm{A}$ : réz-kén eloszlás; $\mathrm{B}$ : az alapként szolgáló SEM felvétel.

A nikkeltartalmú minták szintézisekor is nagyon hasonló interkalációs viselkedést figyelhettünk meg. A pH beállítása során a legfontosabb szempont, az volt, hogy ne alakuljon ki melléktermék (például $\mathrm{Ni}(\mathrm{OH})_{2}$ ) így $\mathrm{pH}=7,5$ feletti értéket nem volt 
lehetséges alkalmazni. A tirozinátot tartalmazó, valamint a hisztidinátot tartalmazó mintát a $B$ módszerrel sikerült elöállítani. A tirozináttartalmú minta esetében is $4: 1$ nominális ligandum/átmeneti fém arányt kellett alkalmazni, a hisztidinát komplexek beépítése esetén ez az arány 2:1 volt. A röntgen diffraktogramok mindkét esetben alátámasztották az interkaláció sikerességét, ugyanis a hisztidinát komplex esetén $0,85 \mathrm{~nm}$-röl $0,94 \mathrm{~nm}$-re, míg a tirozinátot tartalmazó kompozit esetében 0,89 nm-re nőtt a rétegtávolság (25. ábra). Az ATR-IR és PA-IR spektrumok ismét azt mutatták, hogy nem kötődhetett meg nagy mennyiségü komplex az LDH felületén (26. ábra). Az eltolódott karboxilát rezgések pedig azt bizonyítják (1500 és $1620 \mathrm{~cm}^{-1}$ ), hogy kölcsönhatás alakult ki az aminosav anionok és a rétegek között.

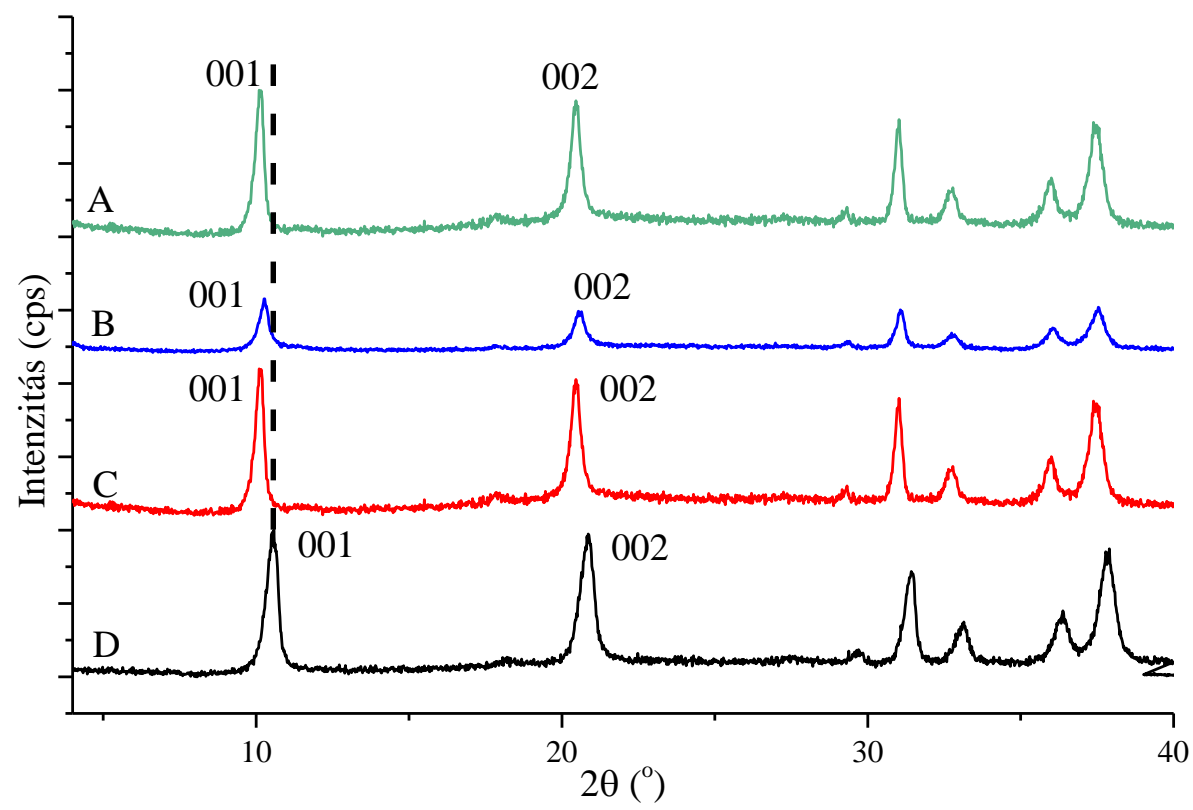

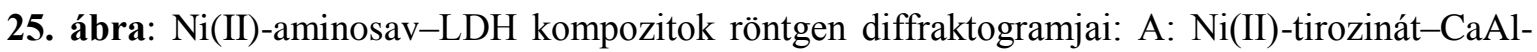
LDH; B: CaAl-Ni(II)-ciszteinát-LDH; C: Ni(II)-hisztidinát-CaAl-LDH; D: CaAl-LDH.

A ciszteináttartalmú rendszer viselkedése ismét eltér, a sikeres szintézishez az $A$ módszert kellett igénybe venni, 4:1 nominális ligandum/fém ion arány alkalmazásával. A rétegtávolság növekedés, a kiindulási $0,85 \mathrm{~nm}$-röl $0,89 \mathrm{~nm}$-re nőtt, ebben az esetben is bizonyította a beépítés sikerességét (25 ábra). Az ATR-IR spektrumok itt is sávszegények voltak, vagyis nem adszorbeálódott a felületre a jelentős mennyiségü komplex vagy aminosav anion (26. ábra). 

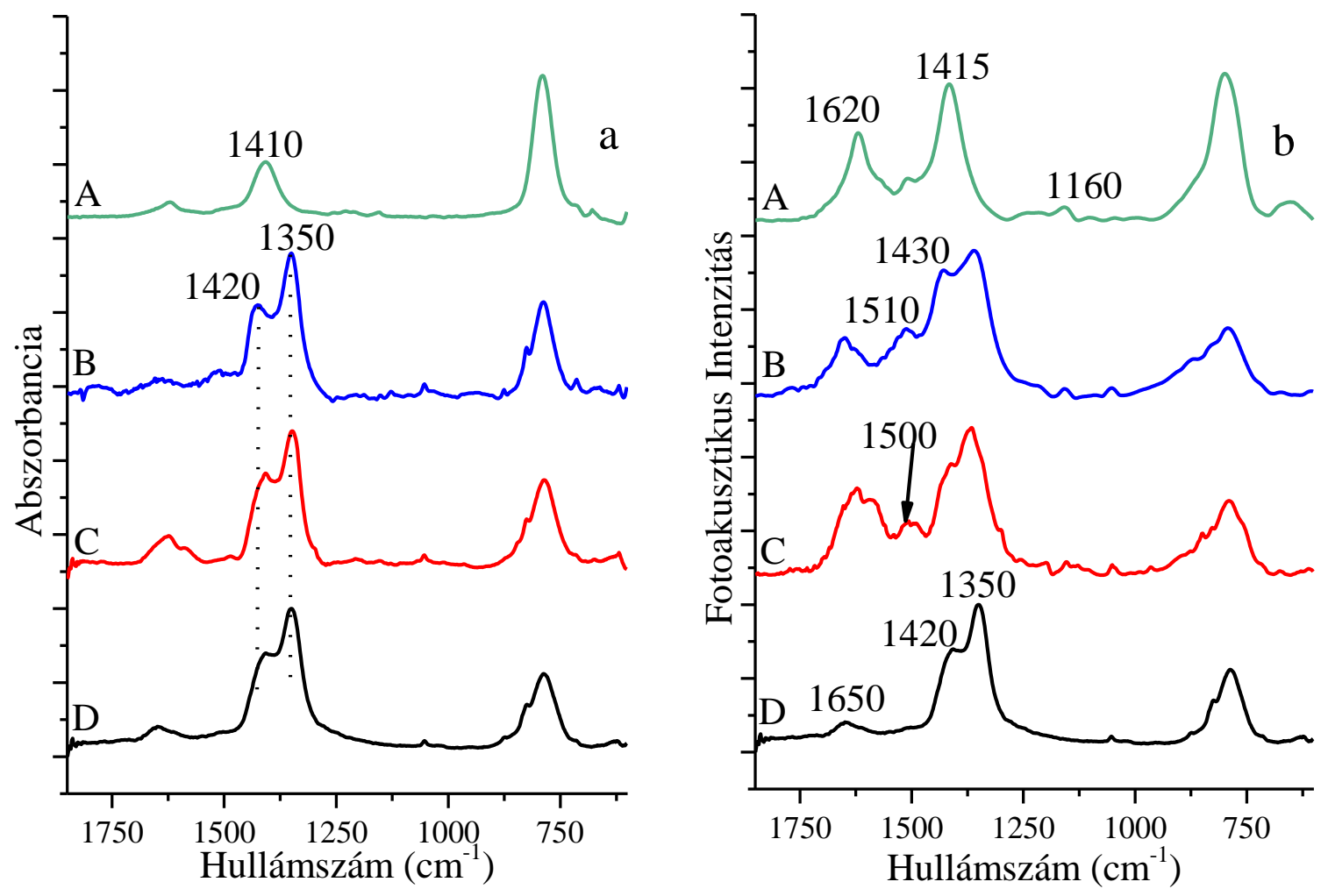

26. ábra: $\mathrm{Ni}(\mathrm{II})$-aminosav-LDH kompozitok ATR-IR (a) és PA-IR spektrumai (b): A: Ni(II)tirozinát-CaAl-LDH; B: CaAl-Ni(II)-ciszteinát-LDH; C: Ni(II)-hisztidinát-CaAl-LDH; D: CaAlLDH.

A nikkeltartalmú komplexek beépítésével még az LDH kristályosságán is sikerült javítani, amint azt a SEM képeken az élesen kirajzolódó hatszöges morfológia jelzi (27. ábra). 


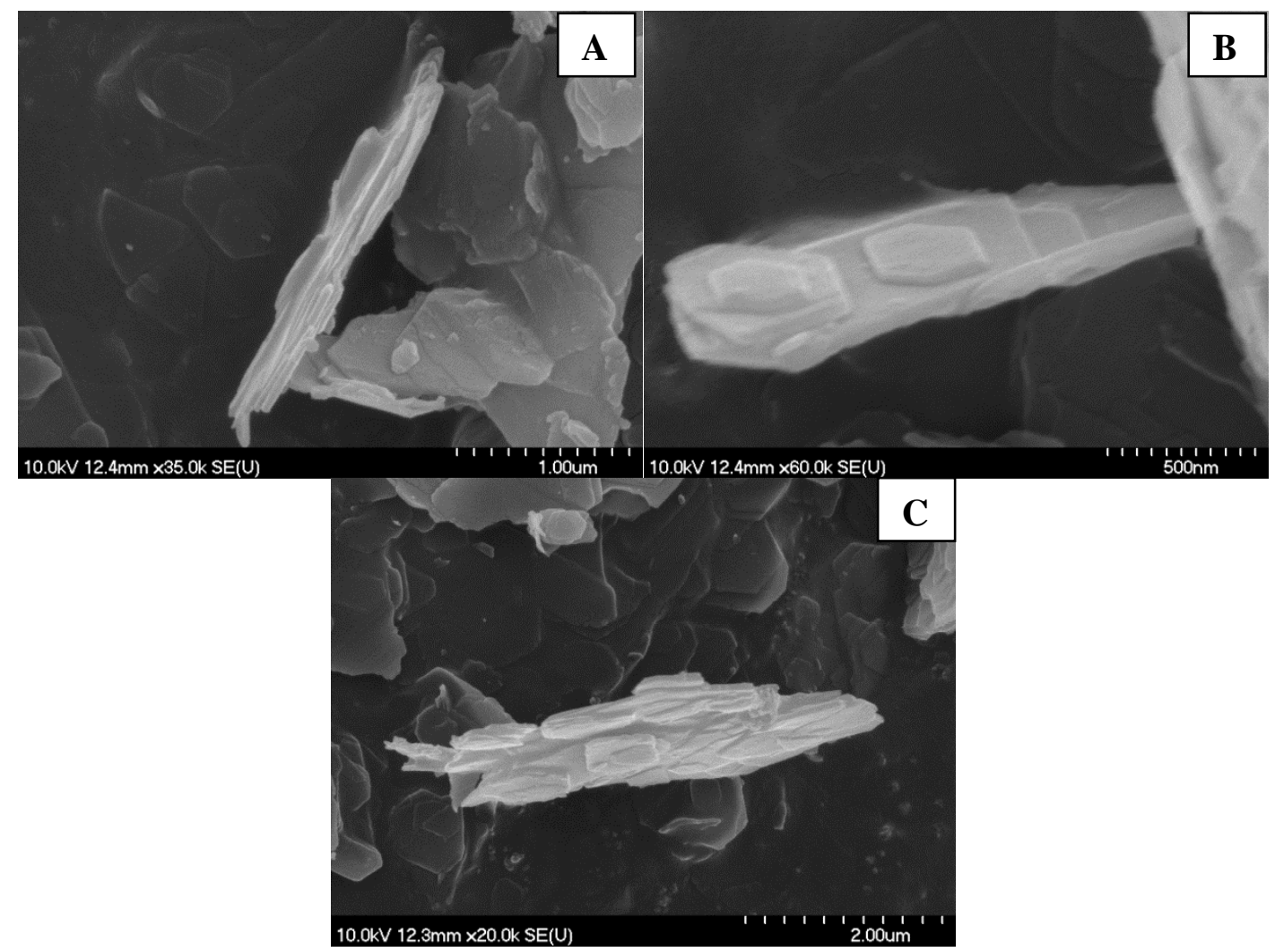

27. ábra: $\mathrm{Ni}(\mathrm{II})-a m i n o s a v-L D H$ kompozitok SEM felvételei: $\mathrm{A}$ : Ni(II)-tirozinát-CaAl-LDH; B: CaAl-Ni(II)-ciszteinát-LDH; C: Ni(II)-hisztidinát-CaAl-LDH.

A Fe(III)-tartalmú minták minden esetben jelentős rétegtávolság növekedést mutattak (28. ábra). A tirozináttartalmú minta esetében 1,10 nm-re, a ciszteináttartalmú minta esetében 1,15 nm-re, míg hisztidináttartalmú minta esetében $0,91 \mathrm{~nm}$-re növekedett a rétegtávolság a kiindulási 0,85 nm-ről. Hasonlóan az előzőekhez, ebben az esetben is a tirozinát- és hisztidináttartalmú mintáknál a $B$ módszer vezetett eredményre, míg a ciszteináttartalmúaknál az $A$ módszer. Minden esetben 4:1 nominális ligandum/fém ion arányt kellett beállítani, valamint vizes etanol oldószer alkalmazására volt szükség. A pH beállítása jelentette a legnagyobb problémát, mert el kellett kerülni a Fe(III)-oxid-hidroxid leválását. A ciszteinát ionokat tartalmazó minta esetében szerencsére nem volt szükséges lúgos $\mathrm{pH}$ alkalmazására, a komplex így is ki tudott alakulni a rétegek között. A másik két esetben sem alklamazhattunk $\mathrm{pH}>8$ körülményeket. A diffraktogramokon látható alapvonal emelkedés azt jelzi, hogy minden kompozit tartalmazott amorf fázist is, feltehetöen $\mathrm{FeO}(\mathrm{OH})$-t. 


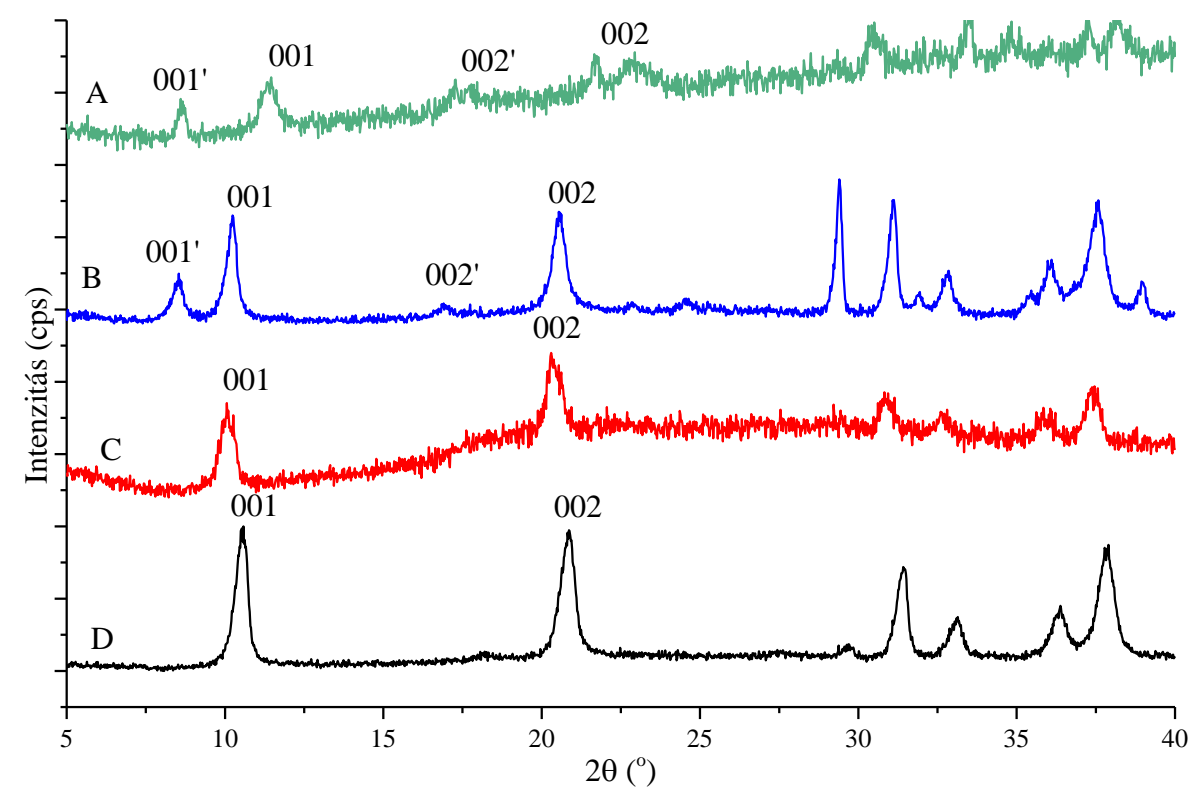

28. ábra: $\mathrm{Fe}(\mathrm{III})$-aminosav-LDH kompozitok röntgen diffraktogramjai: A: Fe(III)-tirozinát-CaAlLDH; B: CaAl-Fe(III)-ciszteinát-LDH; C: Fe(III)-hisztidinát-CaAl-LDH; D: CaAl-LDH.

Az ATR-IR és PA-IR spektrumok összehasonlítása azt mutatta, hogy döntően a rétegek közé sikerült beépíteni a komplexeket, mivel az ATR-IR spektrumokon nem voltak láthatók szerves anyag jelenlétére utaló rezgési sávok (29. ábra). Ez alól kivétel a ciszteináttartalmú minta, amelynél biztosra vehetö, hogy a felületen is megkötödött egy bizonyos mennyiségü szabad ligandum, mivel megjelent a ciszteináthoz köthető két deformációs rezgés 1225 és $1250 \mathrm{~cm}^{-1}$-nél. 

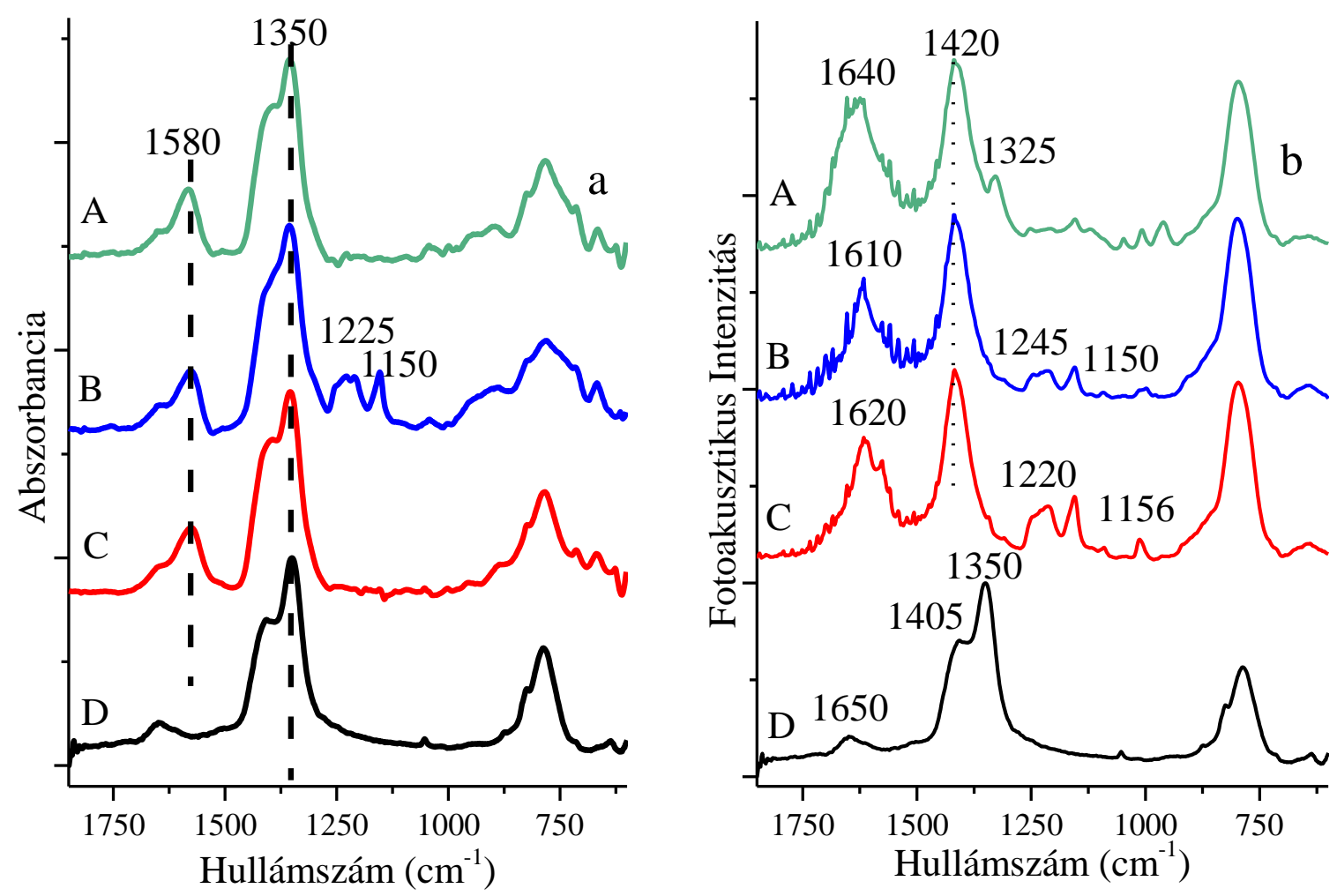

29. ábra: Fe(III)-aminosav-LDH kompozitok ATR-IR (a) és PA-IR spektrumai (b): A: Fe(III)tirozinát-CaAl-LDH， B: CaAl-Fe(III)-ciszteinát-LDH， C: Fe(III)-hisztidinát-CaAl-LDH， D: CaAl-LDH.

A SEM felvételek bizonyítják, hogy az interkalálás után is megmaradt az LDH szerkezet és így az LDH-ra jellemző morfológia (30. ábra). Az EDX elemtérképek szerint a Fe(III) ionok és a ciszteinát ionokból származó kén eloszlása egyenletes a ciszteináttartalmú mintában (31. ábra). 


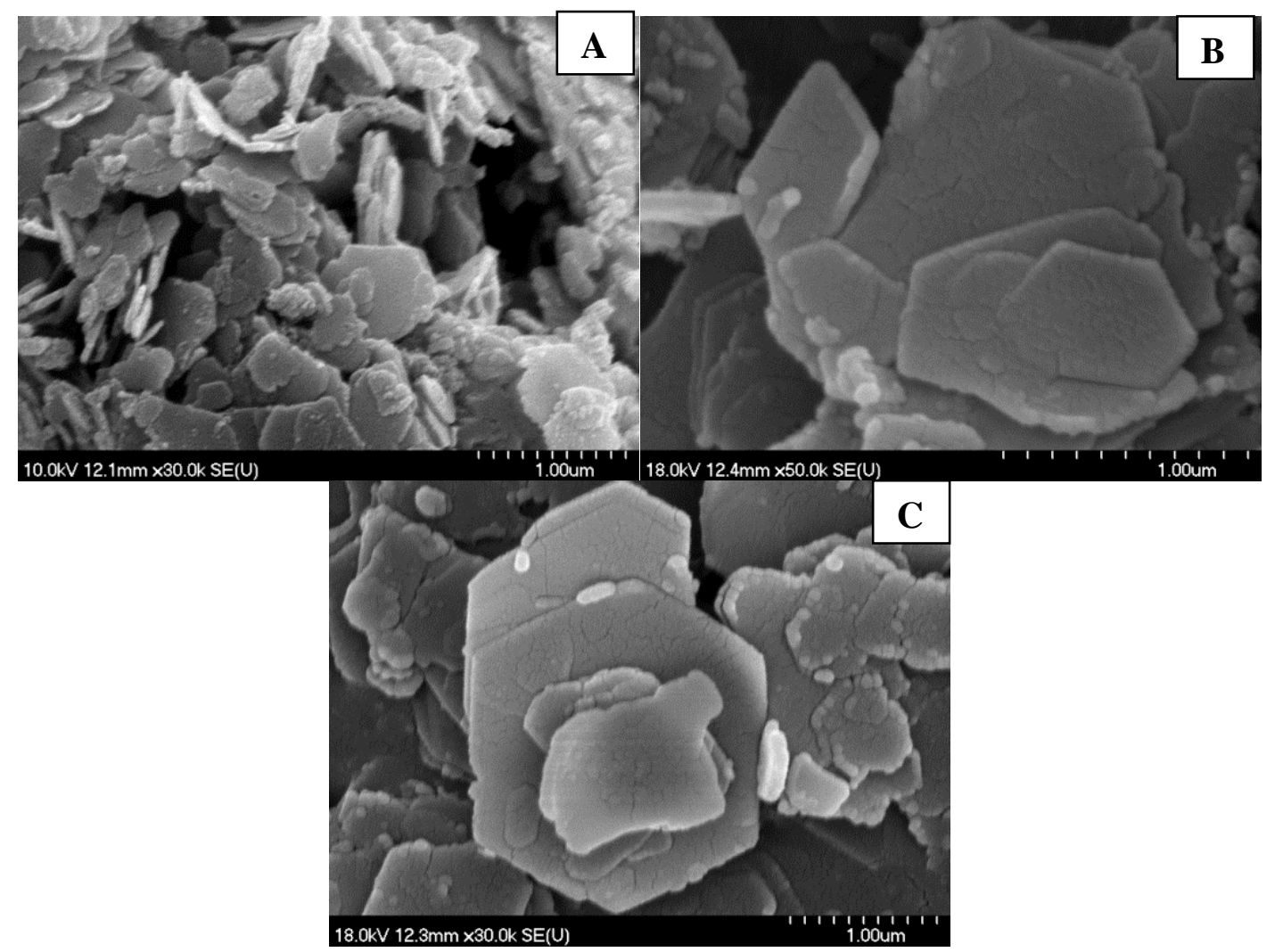

30. ábra: Fe(III)-aminosav-LDH kompozitok SEM felvételei: A: Fe(III)-tirozinát-CaAl-LDH; B: CaAl-Fe(III)-ciszteinát-LDH; C: Fe(III)-hisztidinát-CaAl-LDH.

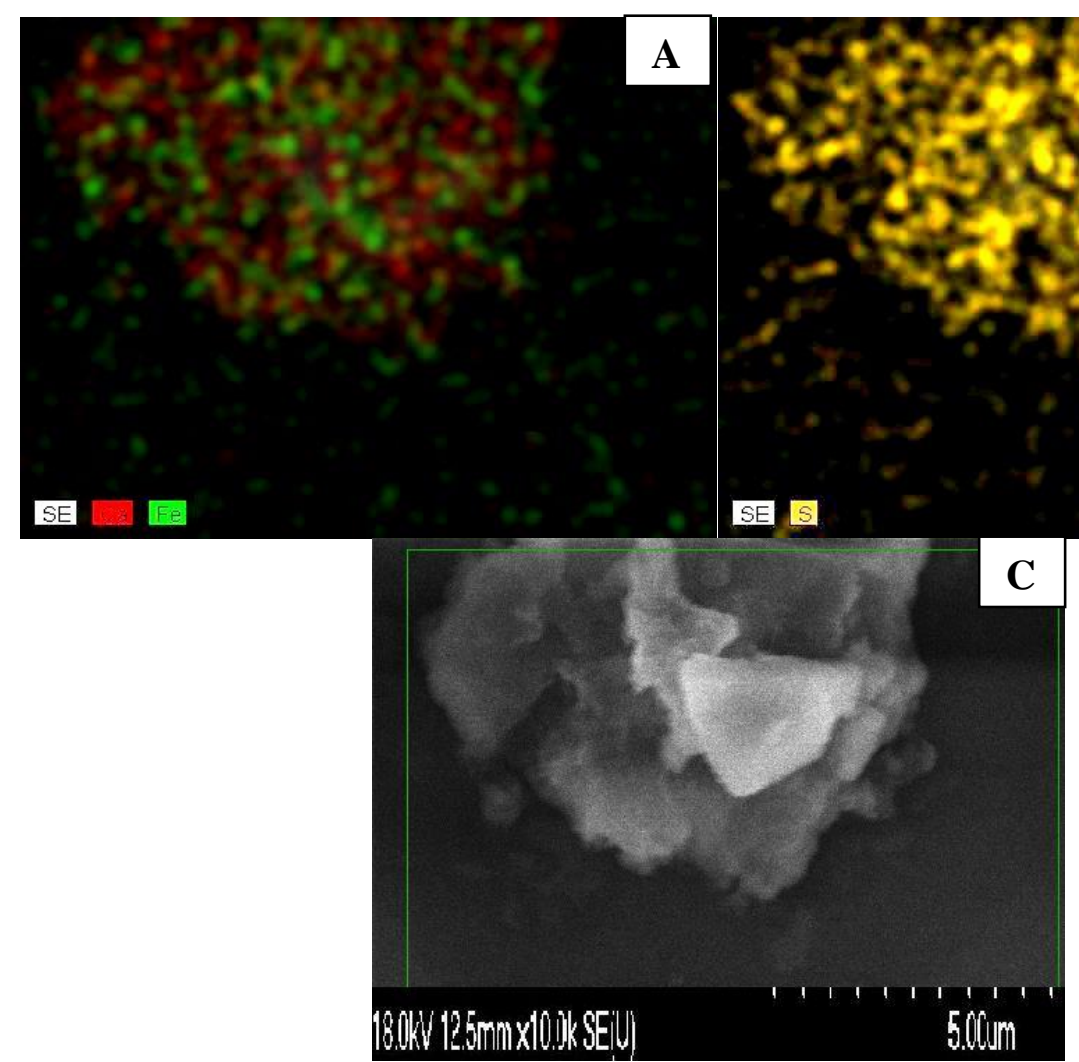

31. ábra: $\mathrm{CaAl}-\mathrm{Fe}(\mathrm{III})$-ciszteinát-LDH kompozit EDX elemtérképei: A: Ca-Fe eloszlás, B: kén eloszlás; C: az alapként szolgáló SEM felvétel. 


\subsection{A beépített komplexek szerkezetazonosítása és mennyiségi meghatározása}

\subsubsection{Mennyiségi meghatározás}

A sikeresen beépített komplex mennyiségi meghatározásából azt lehetett megállapítani, hogy milyen arányban találhatóak meg a fém ionhoz képest az aminosav anionok. Ezzel kapunk egy képet arról, hogy milyen összetételü komplexek lehetnek egyáltalán a rendszerben. A következő fejezetekben csupán a komplexet (M(II)/M(III)-az aminosav anion rövidítése) tüntetjük fel a táblázatokban, a gazda LDH-t nem.

Megállapítottuk, hogy minden kompozit esetén, a bemérési aránytól függetlenül, elég jó közelítéssel 2:1-nek adódott a rétegközi térben az aminosav/fém ion arány (4. táblázat). Az azt jelenti, hogy jó közelítéssel egyfajta komplex van az LDH rétegei között.

A mennyiségi meghatározások szerint általában a bevitt ligandumoknak körülbelül a 10-15\%-a maradt a rendszerben a szintézis végeztével. A Fe(III)-Cys-, illetve Fe(III)-Tyrtartalmú kompozitok esetében ez az arány 30-40\% volt.

4. táblázat: A sikeresen beépített komplexek aminosav/fém ion arányának meghatározása.

\begin{tabular}{cccc}
\hline $\begin{array}{c}\text { CaAl-LDH } \\
\text { kompozitok }\end{array}$ & $\begin{array}{c}\text { Aminosav } \\
(\mathrm{mol} / 0,3 \mathrm{~g} \mathrm{LDH})\end{array}$ & $\begin{array}{c}\text { Fém ion } \\
(\mathrm{mol} / 0,3 \mathrm{~g} \mathrm{LDH})\end{array}$ & Aminosav/fém ion \\
\hline $\mathrm{Mn}$ (II)-Cys & $2,3 \times 10^{-4}$ & $1,0 \times 10^{-4}$ & 2,2 \\
$\mathrm{Mn}$ (II)-His & $2,3 \times 10^{-4}$ & $1,0 \times 10^{-4}$ & 2,2 \\
$\mathrm{Mn}$ (II)-Tyr & $2,2 \times 10^{-4}$ & $1,1 \times 10^{-4}$ & 2,1 \\
\hline $\mathrm{Cu}$ (II)-Cys & $2,5 \times 10^{-4}$ & $1,2 \times 10^{-4}$ & 2,1 \\
$\mathrm{Cu}$ (II)-His & $2,2 \times 10^{-4}$ & $1,1 \times 10^{-4}$ & 2,0 \\
$\mathrm{Cu}$ (II)-Tyr & $3,8 \times 10^{-4}$ & $1,8 \times 10^{-4}$ & 2,1 \\
\hline $\mathrm{Ni}(\mathrm{II})-\mathrm{Cys}$ & $3,5 \times 10^{-4}$ & $1,8 \times 10^{-4}$ & 1,9 \\
$\mathrm{Ni}$ (II)-His & $6,2 \times 10^{-4}$ & $3,0 \times 10^{-4}$ & 2,1 \\
$\mathrm{Ni}(\mathrm{II})-\mathrm{Tyr}$ & $1,9 \times 10^{-4}$ & $9,0 \times 10^{-5}$ & 2,1 \\
\hline $\mathrm{Fe}(\mathrm{III})-\mathrm{Cys}$ & $8,0 \times 10^{-4}$ & $3,7 \times 10^{-4}$ & 2,2 \\
$\mathrm{Fe}(\mathrm{III})-\mathrm{His}$ & $2,3 \times 10^{-4}$ & $1,4 \times 10^{-4}$ & 1,7 \\
$\mathrm{Fe}$ (III)-Tyr & $6,9 \times 10^{-4}$ & $3,3 \times 10^{-4}$ & 2,1 \\
\hline
\end{tabular}

\subsubsection{Távoli IR és Raman spektroszkópiai vizsgálatok}

A távoli IR és a kéntartalmú minták esetén a Raman spektrumokból információk nyerhetők a koordinációs szférát kialakító molekulákról, illetve donorcsoportokról. A távoli IR spektrumok értelmezését egy már korábban publikált (és a korábbiakban már említett) korrelációs táblázat tette lehetővé.

Első lépésként a nitráttartalmú CaAl-LDH spektrumát értelmeztük (32. ábra). Ebben három jelentős csúcs található. A $290 \mathrm{~cm}^{-1}$-nél látható sáv a nitrát ion egyik deformációs 
rezgéséhez köthető, a $350 \mathrm{~cm}^{-1}$-nél látható sáv az $\mathrm{O}-\mathrm{Al}-\mathrm{O}$ egyik deformációs rezgéséhez köthető, és $450 \mathrm{~cm}^{-1}$-nél megjelenik a víz deformációs rezgéseinek szuperpozíciója. ${ }^{182}$

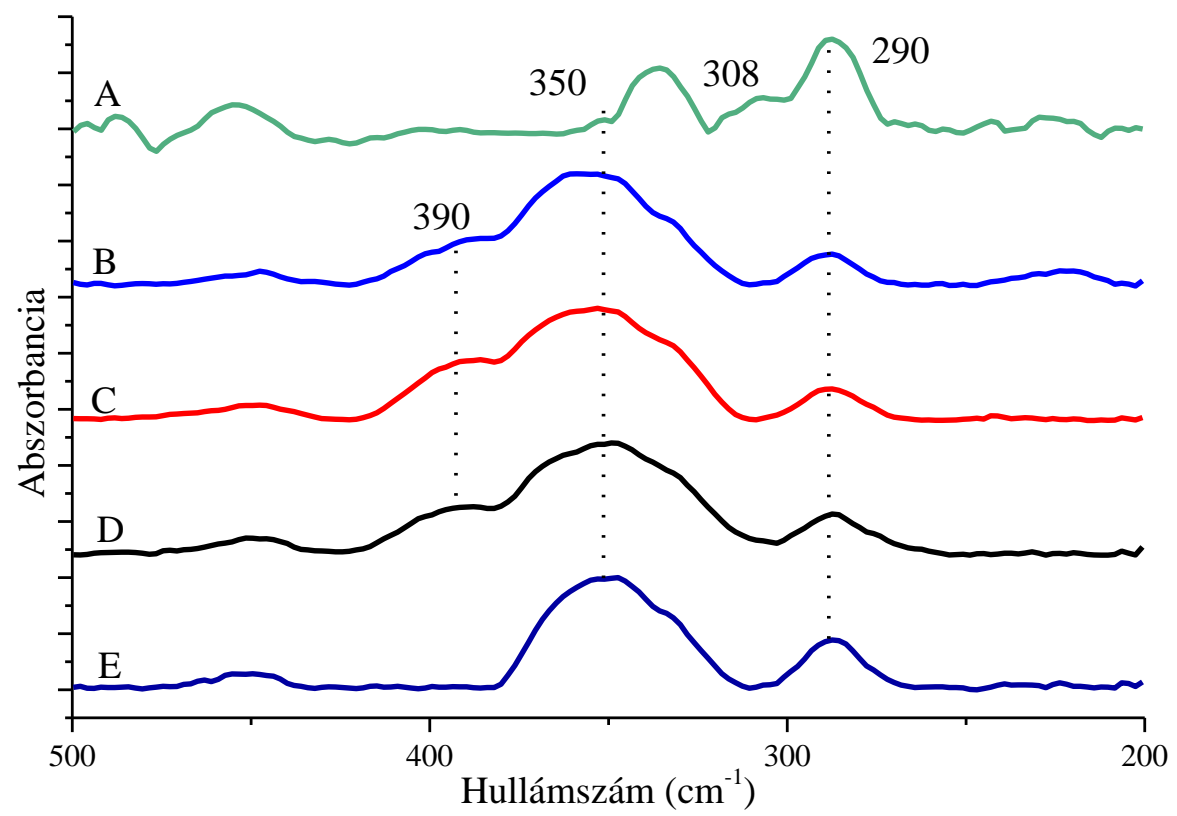

32. ábra: Tirozinát-tartalmú LDH kompozitok távoli IR spektrumai: A: Fe(III)-tirozinát-CaAlLDH; B: Ni(II)-tirozinát-CaAl-LDH; C: Cu(II)-tirozinát-CaAl-LDH; D: Mn(II)-tirozinát-CaAlLDH; E: CaAl-LDH.

A tirozináttartalmú komplexek esetén bebizonyosodott, hogy minden esetben vízmolekula oxigénje részt vesz a koordinációban. A kialakuló $\mathrm{M}(\mathrm{II})-\mathrm{O}$ kötés vegyértékrezgése látható a kompozitok spektrumában $390 \mathrm{~cm}^{-1}$ körül (32. ábra, B-D spektrumok). A Fe(III)-tirozináttartalmú kompozit spektrumában a $308 \mathrm{~cm}^{-1}$-nél látható új rezgés a fenolos oxigén koordinációjára utal (32. ábra, A spektrum). 


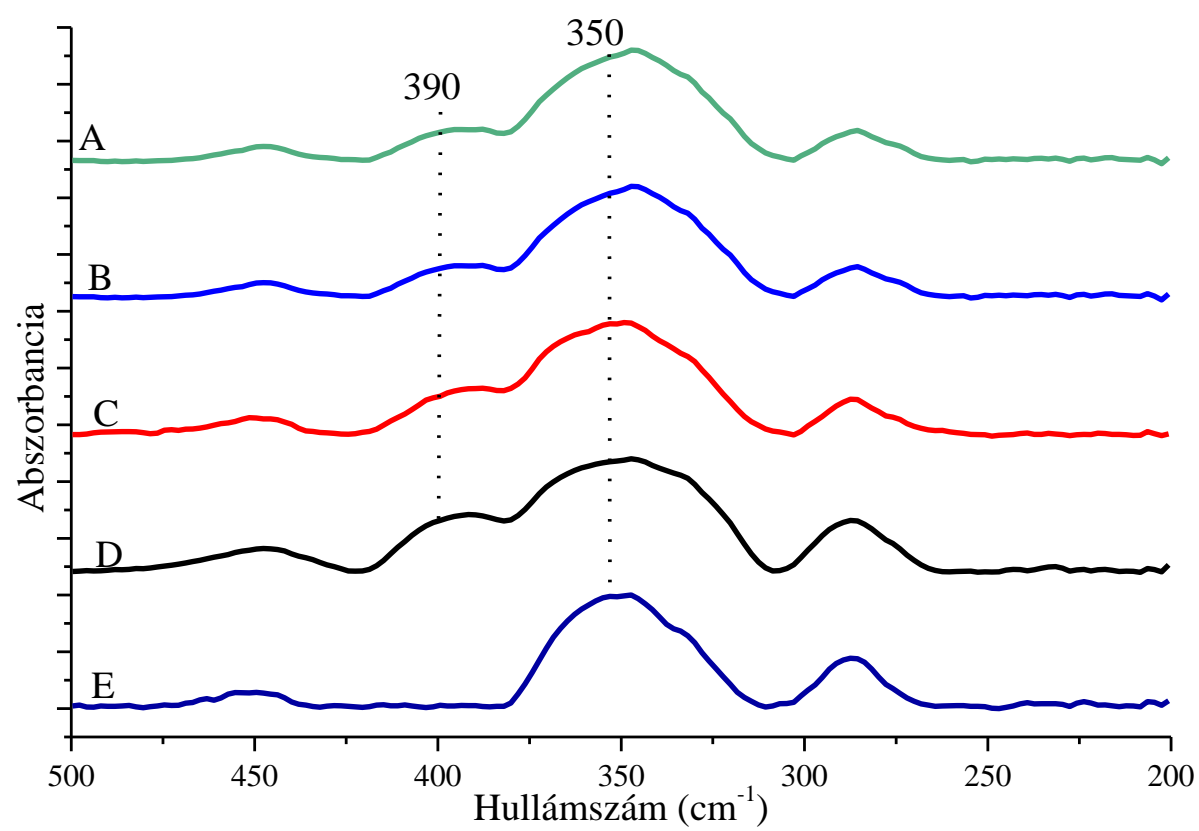

33. ábra: Ciszteináttartalmú LDH kompozitok távoli IR spektrumai: $\mathrm{A}$ : $\mathrm{CaAl}-\mathrm{Fe}(\mathrm{III})-$ ciszteinát-LDH; B: CaAl-Ni(II)-ciszteinát-LDH; C: CaAl-Cu(II)-ciszteinát-LDH; D: Mn(II)ciszteinát-CaAl-LDH; E: CaAl-LDH.

A ciszteináttartalmú kompozitok spektrumai minden esetben tartalmaztak egy 390 $\mathrm{cm}^{-1}$-nél megjelenő sávot (33. ábra), amely vízmolekula oxigénjének koordinációjára utal. Amennyiben a ciszteinátban megtalálható tiolcsoport vagy deprotonálódás esetén tiolátcsoport kénatomja részt is vesz a koordinációban, akkor sem tapasztalhattam volna új rezgés megjelenését, mivel a tiol- vagy tiolátcsoporthoz köthető rezgések Raman aktívak. A felvett Raman spektrumokból (34. ábra) két fontos dolgot sikerült megállapítani. Egyrészt, az $500 \mathrm{~cm}^{-1}$-nél magasabb értéknél található nagy intenzitású jel egyértelmüen bizonyította, hogy a ciszteinát nem oxidálódott cisztinné - ellenkező esetben $450 \mathrm{~cm}^{-1}$-nél meg kellett volna jelennie a S-S kötéshez tartozó rezgésnek. ${ }^{183}$ Amikor Ni(II)-cisztinát komplexet interkaláltunk a S-S kötés rezgése meg is jelent $450 \mathrm{~cm}^{-1}$-nél (34. ábra, A spektrum). Az is megállapítható a Raman spektrumokból, hogy a tiol-/tiolátcsoporthoz tartozó rezgés minden esetben eltolódott a kiindulási ciszteinátban található rezgéshez képest $\left(720 \mathrm{~cm}^{-1}-\mathrm{C}-\mathrm{S}\right.$ vegyérték rezgés), ami bizonyítja ennek a csoport koordinációját. Kis intenzitással ugyan, de még az interkaláció után is megfigyelhető a „szabad” ciszteináthoz tartozó rezgés. 


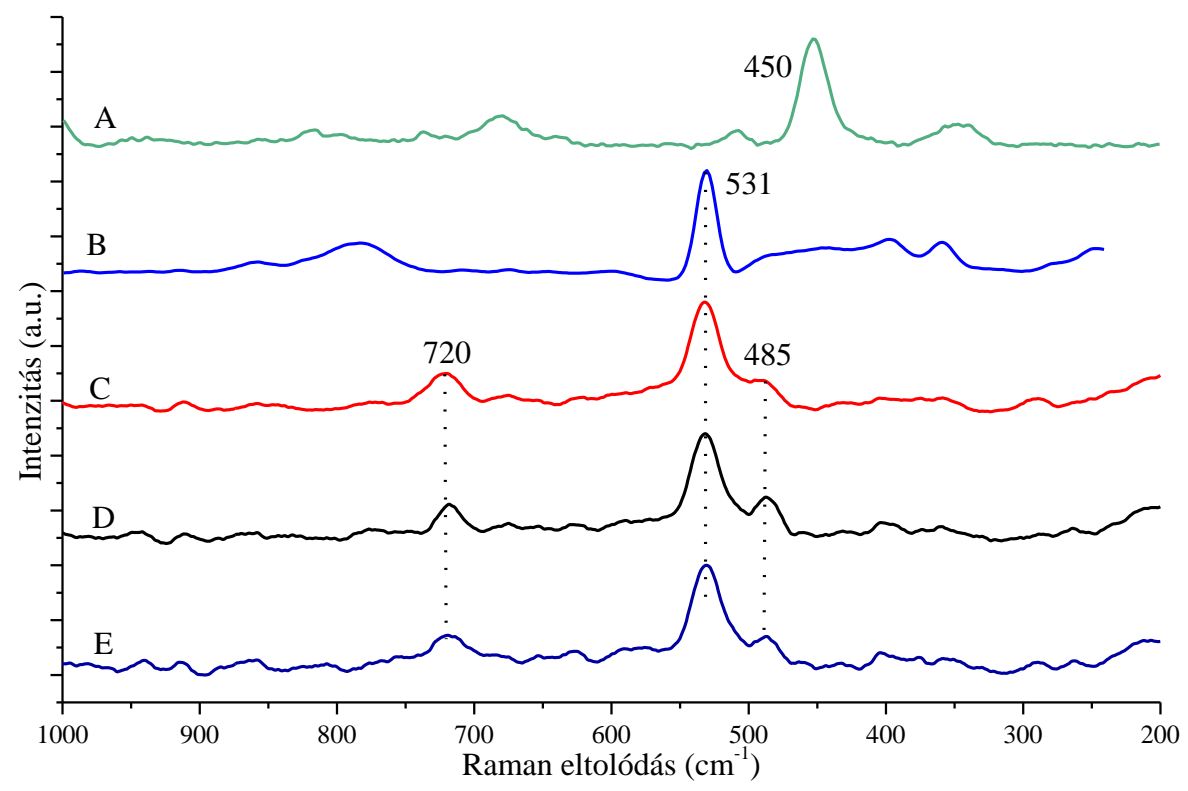

34. ábra: Ciszteináttartalmú LDH kompozitok Raman spektrumai: A: CaAl-Ni(II)-cisztinát-LDH; B: CaAl-Ni(II)-ciszteinát-LDH; C: CaAl-Cu(II)-ciszteinát-LDH; D: Mn(II)-ciszteinát-Ca ${ }_{2} \mathrm{Al}-$ LDH; E: CaAl-Fe(III)-ciszteinát-LDH.

A hisztidináttartalmú minták spektrumai voltak a legösszetettebbek (35. ábra). Minden esetben megjelent két rezgés $\sim 220 \mathrm{~cm}^{-1}$ és $\sim 400 \mathrm{~cm}^{-1}$ körül. A kisebb hullámszámnál megjelenő sáv az imidazolát nitrogén koordinációját jelzi. A nagyobb értéknél megjelenő sáv pedig ebben az esetben is a vízmolekula részvételét támasztja alá a koordinációban. A Ni(II)-tartalmú kompozit spektrumában megjelent két sáv 340 és 240 $\mathrm{cm}^{-1}$-nél. A sávpár megjelenésére az aminonitrogén koordinációja esetén számíthatunk (35. ábra, $\mathrm{C}$ spektrum). 


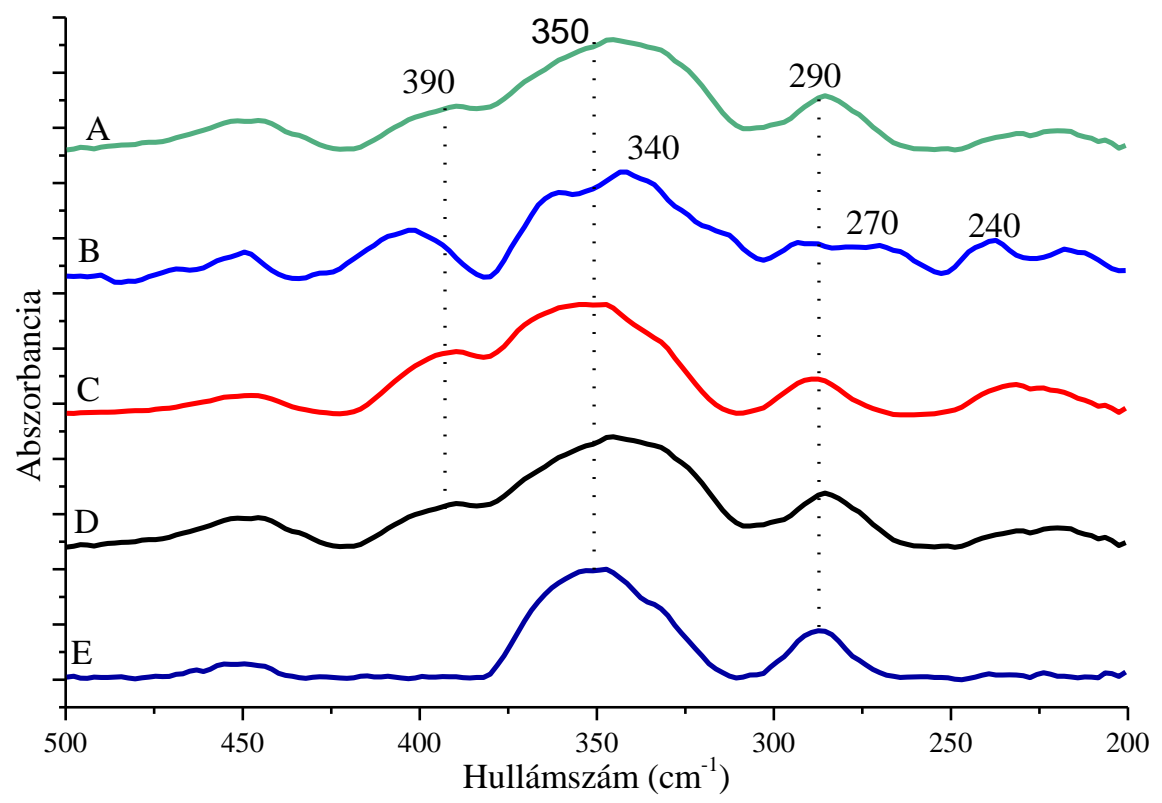

35. ábra: Hisztidináttartalmú LDH kompozitok távoli IR spektrumai: A: Fe(III)-hisztidinát-CaAlLDH; B: Ni(II)-hisztidinát-CaAl-LDH; C: Cu(II)-hisztidinát-CaAl-LDH; D：CaAl-Mn(II)hisztidinát-LDH; E: CaAl-LDH.

\subsubsection{ESR spektrumokból nyerhető szerkezeti információk}

Az ESR spektrumok értelmezéséből információt reméltünk a komplexben lévő fém ionok koordinációs számáról és geometriájáról is.

A $\mathrm{Mn}(\mathrm{II})-$, valamint a $\mathrm{Cu}(\mathrm{II})$-t tartalmazó rendszereket tudtuk megvizsgálni ESR spektroszkópia segítségével, mivel a másik két rendszer esetében nem kaptunk értelmezhető hiperfinom felhasadást még $77 \mathrm{~K}$-en sem.

A CaAl-Mn(II)-hisztidinát-LDH és a Mn(II)-ciszteinát-CaAl-LDH kompozitok spektruma igen hasonló (36. ábra). Mindkét spektrum hat jól elkülönült hiperfinom vonalból épül fel, amelyek az elektronspinnek a magspinnel történő kölcsönhatásából származnak $\left({ }^{55} \mathrm{Mn}, \mathrm{I}=5 / 2\right)$. Mivel a mangántartalmú minták esetében mind a $\Delta M_{S}= \pm 1$, $\Delta M_{I}= \pm 1$, valamint a $\Delta M_{S}= \pm 1$ és $\Delta M_{I}=0$ átmenetek megengedettek, így már értelmezhető, hogy a hat felhasadt jelre miért szuperponálódott öt darab dublett. A felhasadt jelek a $\Delta M_{I}=0$, a dublettek a másik átmenethez tartoznak. Ez a spektrumszerkezet azokra a Mn(II)-tartalmú mintákra jellemző, amelyek axiálisan torzult szerkezettel rendelkeznek. Továbbá a mangánkomplex nem lehet többmagvú egyik esetben sem, mivel ebben az esetben egy szingulett jel szuperponálódott volna a fentebb leírt felhasadásokra, a paramágneses mangán centrumok kölcsönhatása miatt. ${ }^{184}$ Ez a hatás tette lehetetlenné azt, hogy a tirozináttartalmú mintáról értelmezhető spektrumot kapjunk. 


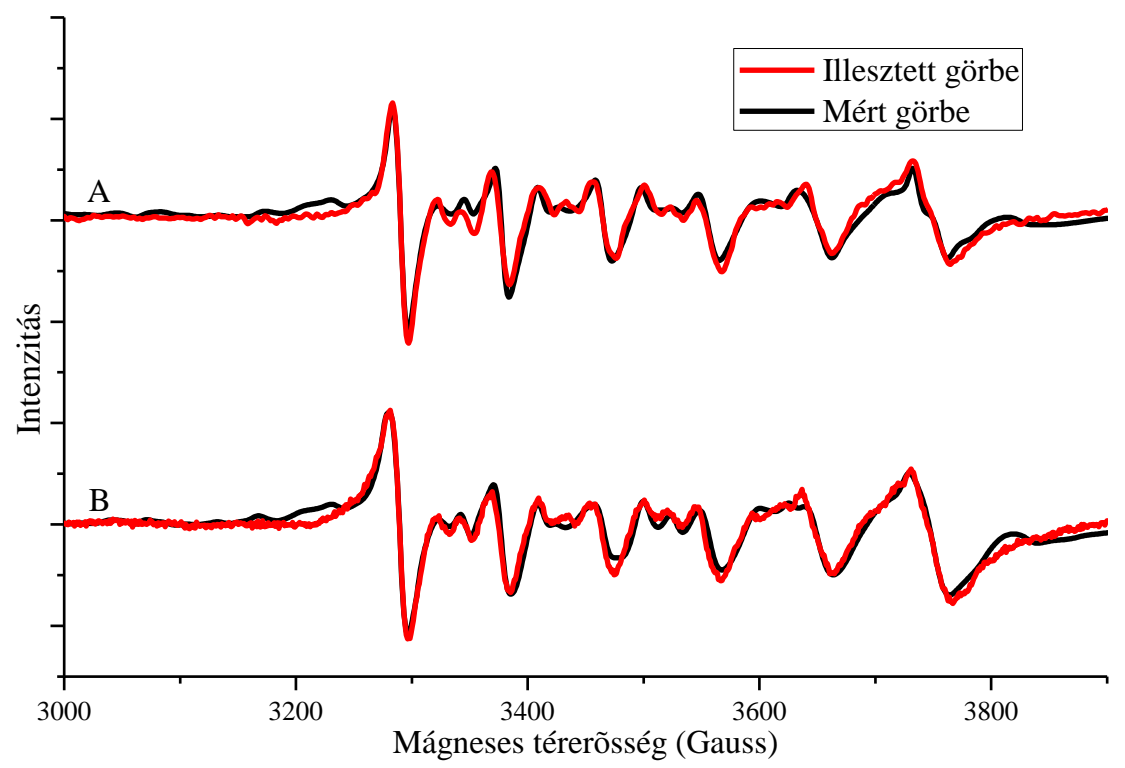

36. ábra: $\mathrm{Mn}(\mathrm{II})$-aminosav-LDH kompozitok ESR spektrumai: A: CaAl-Mn(II)-hisztidinát-LDH; B: Mn(II)-ciszteinát-CaAl-LDH.

A mért görbéket illesztettük és a legfontosabb paramétereket kiszámítottuk, ezeket az 5. táblázatban foglaltam össze. Mindkét minta esetében két különböző komponens szuperpozíciójaként lehetett leírni a görbéket. Ez nagy valószínűséggel azt jelenti, hogy a rétegek között (ha csak kis mennyiségben is) elöfordulhat 2:1 aminosav/fém ion aránytól eltérö összetételü komplex is. Az illesztett paraméterek közül a gav (giromágneses tényezö) értékből sajnos nem tudtunk információt kinyerni, mert ez alig tért el a szabad elektron $g$ tényezőjétől $(2,0023)$.

5. táblázat: A mangántartalmú LDH-kompozitok ESR paraméterei.

\begin{tabular}{ccccccccccc}
\hline $\begin{array}{c}\text { CaAl-LDH } \\
\text { kompozitok }\end{array}$ & $\mathrm{g}_{\mathrm{x}}$ & $\mathrm{g}_{\mathrm{y}}$ & $\mathrm{g}_{\mathrm{z}}$ & $\mathrm{g}_{\mathrm{av}}$ & $\begin{array}{c}\mathrm{A}_{\mathrm{x}} \\
\left(\mathrm{cm}^{-1}\right)\end{array}$ & $\begin{array}{c}\mathrm{A}_{\mathrm{y}} \\
\left(\mathrm{cm}^{-1}\right)\end{array}$ & $\begin{array}{c}\mathrm{A}_{\mathrm{z}} \\
\left(\mathrm{cm}^{-1}\right)\end{array}$ & $\begin{array}{c}\mathrm{A}_{\mathrm{av}} \\
\left(\mathrm{cm}^{-1}\right)\end{array}$ & $\begin{array}{c}\mathrm{D} \\
\left(\mathrm{cm}^{-1}\right)\end{array}$ & $\begin{array}{c}\mathrm{E} \\
\left(\mathrm{cm}^{-1}\right)\end{array}$ \\
\hline $\begin{array}{c}\text { Mn(II)-His } \\
\text { (komp. 1) }\end{array}$ & $\begin{array}{c}1,98 \\
40\end{array}$ & 2,0091 & 2,0182 & 2,0038 & 0,0084 & 0,0098 & 0,0092 & 0,0091 & 0,0261 & 0,0015 \\
$\begin{array}{c}\text { Mn(II)-His } \\
\text { (komp. 2) }\end{array}$ & $\begin{array}{c}1,98 \\
52\end{array}$ & 1,9908 & 2,0360 & 2,0040 & 0,0082 & 0,0090 & 0,0061 & 0,0077 & 0,0185 & 0,0030 \\
\hline $\begin{array}{c}\text { Mn(II)-Cys } \\
\text { (komp. . })\end{array}$ & $\begin{array}{c}1,98 \\
03\end{array}$ & 2,0072 & 2,0188 & 2,0021 & 0,0083 & 0,0096 & 0,0091 & 0,0090 & 0,0267 & 0,0015 \\
$\begin{array}{c}\text { Mn(II)-Cys } \\
\text { (komp. 2) }\end{array}$ & $\begin{array}{c}1,98 \\
25\end{array}$ & 1,9849 & 2,0357 & 2,0010 & 0,0084 & 0,0086 & 0,0062 & 0,0077 & 0,0195 & 0,0028 \\
\hline
\end{tabular}

A hiperfinom csatolási állandóból $\left(A_{a v}\right)$ azt lehetett megállapítani, hogy a rétegek között, csak oktaéderes komplexek helyezkednek el. Tetraédres vagy síknégyzetes elrendezés esetében $\sim 25 \%$-kal nagyobb értékeket kaptunk volna. ${ }^{185}$

A $D$ érték (zérustér felhasadás) ugyanakkor nagyon érzékeny a $\mathrm{Mn}$ (II) ionok környezetére. Korábban megállapították, hogy $\left[\mathrm{MnL}_{\mathrm{O}, \mathrm{N}}\right]$ összetételü oktaéderes rendszerek esetében, amennyiben a ligandum egy-, vagy kétfogú módon koordinálódik a központi fém 
ionhoz, akkor 0,00087 és $0,0673 \mathrm{~cm}^{-1}$ között lesz a $D$ érték. Amennyiben 0,0420 és 0,1750 $\mathrm{cm}^{-1}$ közé esik a $D$ értéke, akkor viszont három-, négy-, vagy ötfogú ligandum koordinálódik a központi atomhoz. ${ }^{186}$ Ezek alapján azt mondhatjuk, hogy mindkét komplex esetében egy-, vagy kétfogú módon kapcsolódnak a Mn(II)-centrumokhoz.

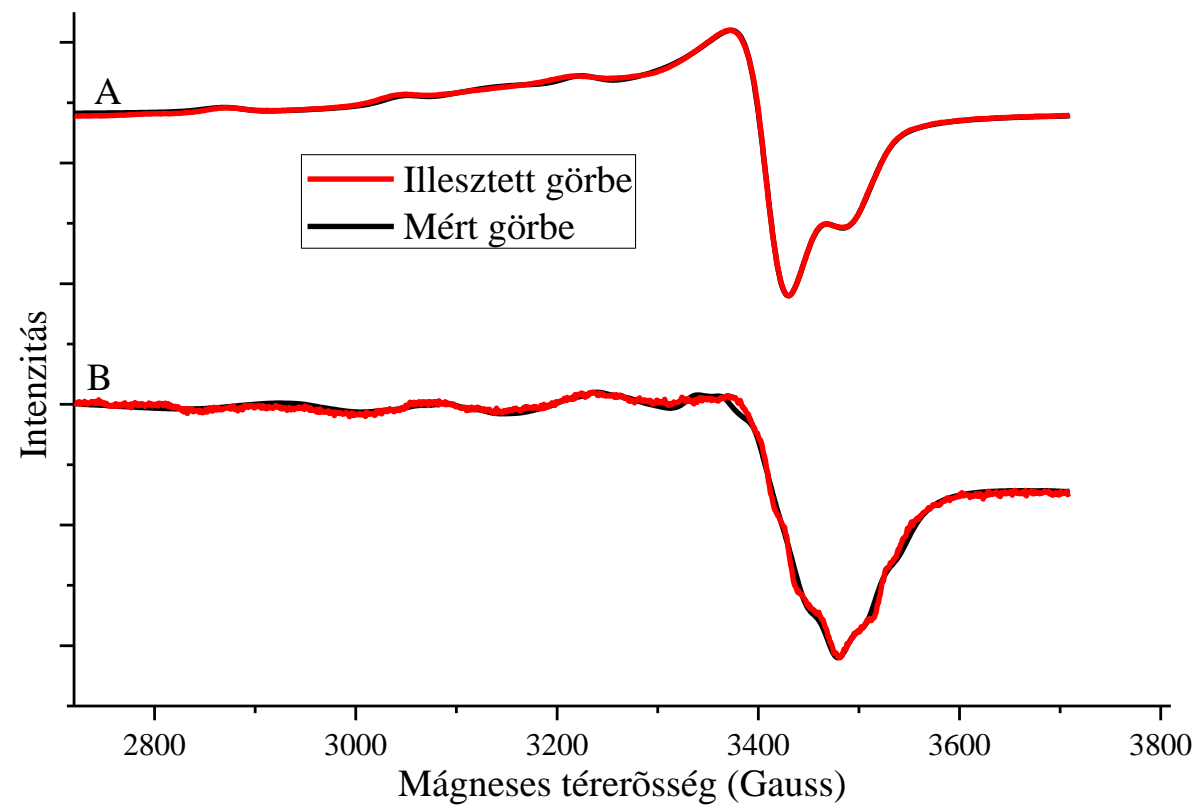

37. ábra: $\mathrm{Cu}$ (II)-aminosav-LDH kompozitok ESR spektrumai: A: CaAl-Cu(II)-ciszteinát-LDH; B: $\mathrm{Cu}(\mathrm{II})$-hisztidinát-CaAl-LDH.

A $\mathrm{Cu}(\mathrm{II})$-tartalmú minták esetében is a hisztidinát- és a ciszteináttartalmú mintáról sikerült értelmezhető spektrumot felvenni (37. ábra). A tirozinát ionokat tartalmazó minta esetében csupán egy szingulett jelet detektáltunk, a fentebb már leírt okok miatt. A mért görbéket megillesztettük, és az illesztett paramétereket az 6. táblázatban mutatjuk be. A $G$ értékek kiszámítása után, és a Hathaway összefüggésre támaszkodva, kijelenthető, hogy az egyetlen illesztett komponens a ligandum és a fém ion közötti kölcsönhatásból származik. ${ }^{187}$ A $G$ paraméter értéke mindkét esetben meghaladja a 4-et, amely már nem származhat csupán a $\mathrm{Cu}-\mathrm{Cu}$ kölcsönhatásból. Mivel $g \|$ nagyobb, mint $g \perp$, így kijelenhető hogy mindkét esetben torzult tetraéderes elrendeződés tételezhető fel, ahol a torzulás a $z$ tengely mentén történik. ${ }^{188} \mathrm{Ez}$ megfelel azoknak a várakozásainknak, hogy a réztartalmú komplexek esetén számolni kell a Jahn-Teller torzulással. Mivel $g \|>g_{\perp}>g_{e}$ sorrend figyelhető meg mindkét kompozit esetében, így azt mondhatjuk, hogy a párosítatlan elektron vélhetően a $\mathrm{Cu}(\mathrm{II})$ ion $\mathrm{dx}^{2}-\mathrm{y}^{2}$ pályáján helyezkedik el. ${ }^{189}$ 
6. táblázat: A réztartalmú LDH-kompozitok ESR paraméterei.

\begin{tabular}{ccccccccccccc}
\hline $\begin{array}{c}\text { CaAl-LDH } \\
\text { kompozitok }\end{array}$ & $\mathrm{g}_{\mathrm{x}}$ & $\mathrm{g}_{\mathrm{y}}$ & $\mathrm{g}_{\perp}$ & $\left.\mathrm{g}_{\mathrm{z}} \mathrm{g} \| \mathrm{g}\right)$ & $\mathrm{G}$ & $\begin{array}{c}\mathrm{A}_{\mathrm{Cux}} \\
(\mathrm{G})\end{array}$ & $\begin{array}{c}\mathrm{A}_{\mathrm{Cuy}} \\
(\mathrm{G})\end{array}$ & $\mathrm{A}_{\perp}$ & $\begin{array}{c}\mathrm{A}_{\mathrm{Cuz}}(\mathrm{All}) \\
(\mathrm{G})\end{array}$ & $\begin{array}{c}\mathrm{A}_{\mathrm{Nx}} \\
(\mathrm{G})\end{array}$ & $\begin{array}{c}\mathrm{A}_{\mathrm{Ny}} \\
(\mathrm{G})\end{array}$ & $\begin{array}{c}\mathrm{A}_{\mathrm{Nz}} \\
(\mathrm{G})\end{array}$ \\
\hline $\mathrm{Cu}(\mathrm{II})-\mathrm{His}$ & 2,042549 & 2,06859 & 2,05557 & 2,323077 & 5,81 & 18,95 & 19,42 & 19,19 & 123,14 & 27,65 & 26,45 & 21,46 \\
$\mathrm{Cu}(\mathrm{II})-\mathrm{Cys}$ & 2,046638 & 2,06004 & 2,05334 & 2,247786 & 4,65 & 11,30 & 15,89 & 13,60 & 160,78 & 11,11 & 7,49 & 20,81 \\
\hline
\end{tabular}

Korábbi irodalmi adatokkal összehasonlítva a kapott értékeket valószínűsítettük, hogy a hisztidinát esetében $\mathrm{N}_{\text {imidazolát }} \mathrm{N}_{\text {amino }} \mathrm{N}_{\text {amino }} \mathrm{O}_{\text {karboxilát koordinációs környezet }}$ feltételezhető a $\mathrm{Cu}(\mathrm{II})$ ion körül. ${ }^{190,191} \mathrm{Az}$ ötödik és hatodik pozíciót a koordinációs szférában nagy valószínűséggel vízmolekulák töltik ki, és valószínüleg ezek állnak a $z$ tengely irányában, vagyis ebben az irányban van a Jahn-teller torzulás. Ezt az alapján feltételeztük, hogy $A \perp$ sokkal kisebb érték, mint $A \|$ vagyis a $z$ tengely irányából „gyenge” ligandumok koordinálódnak. ${ }^{191}$

A ciszteinát esetében, újfent irodalmi analógiákra alapozva, az $S_{\text {tiolát }} S_{\text {tiolát }} N_{\text {amino }} N_{\text {amino }}$ koordinációs környezetet tartjuk a legvalószínübbnek. ${ }^{192,193}$ Ebben az esetben is a vízmolekulák töltik ki a maradék két helyet a koordinációs szférában.

\subsubsection{Az XAS spektrumok értelmezése}

Az XAS spektrumok elemzése információt ad a komplex központi atomjának/ionjának az oxidációs állapotáról és a komplex geometriájáról. A kapott görbék illesztésével meghatározhatók az interatomos távolságokat. Mindezeket együtt kezelve pedig megadható a komplex legvalószínübb szerkezete.

Az illesztések során figyelembe vettük a korábban már bemutatott spektroszkópiai eredményeket, valamint a kvantitatív analízis eredményeit. Az illesztés során arra törekedtünk, hogy az $F$ faktor (amely az illesztés jóságát adja meg) értéke $20 \%$ alatt maradjon, ha több illesztés is ez alatt az érték alatt volt, akkor a legkisebb $F$ faktorral rendelkezőt fogadtuk el.

A mangánnak, amennyiben nulla lenne az oxidációs állapota, akkor $6552,12 \pm 0,12$ eV-nál lenne a $\mathrm{K}$ héjhoz tartozó átmenete. ${ }^{173}$ Ehhez képest az összes kompozit esetében 6556,50 eV-nál jelent meg egy átmenet, ami azt jelenti, hogy a mangán plusz kettes oxidációs állapotban található meg a rendszerben. ${ }^{194}$ A másik fontos információ az, hogy nem látható átmenet a XANES tartományban (38/a ábra), ami azt jelenti, hogy a mangán csak oktaéderes környezetben fordul elő a kompozitokban. 

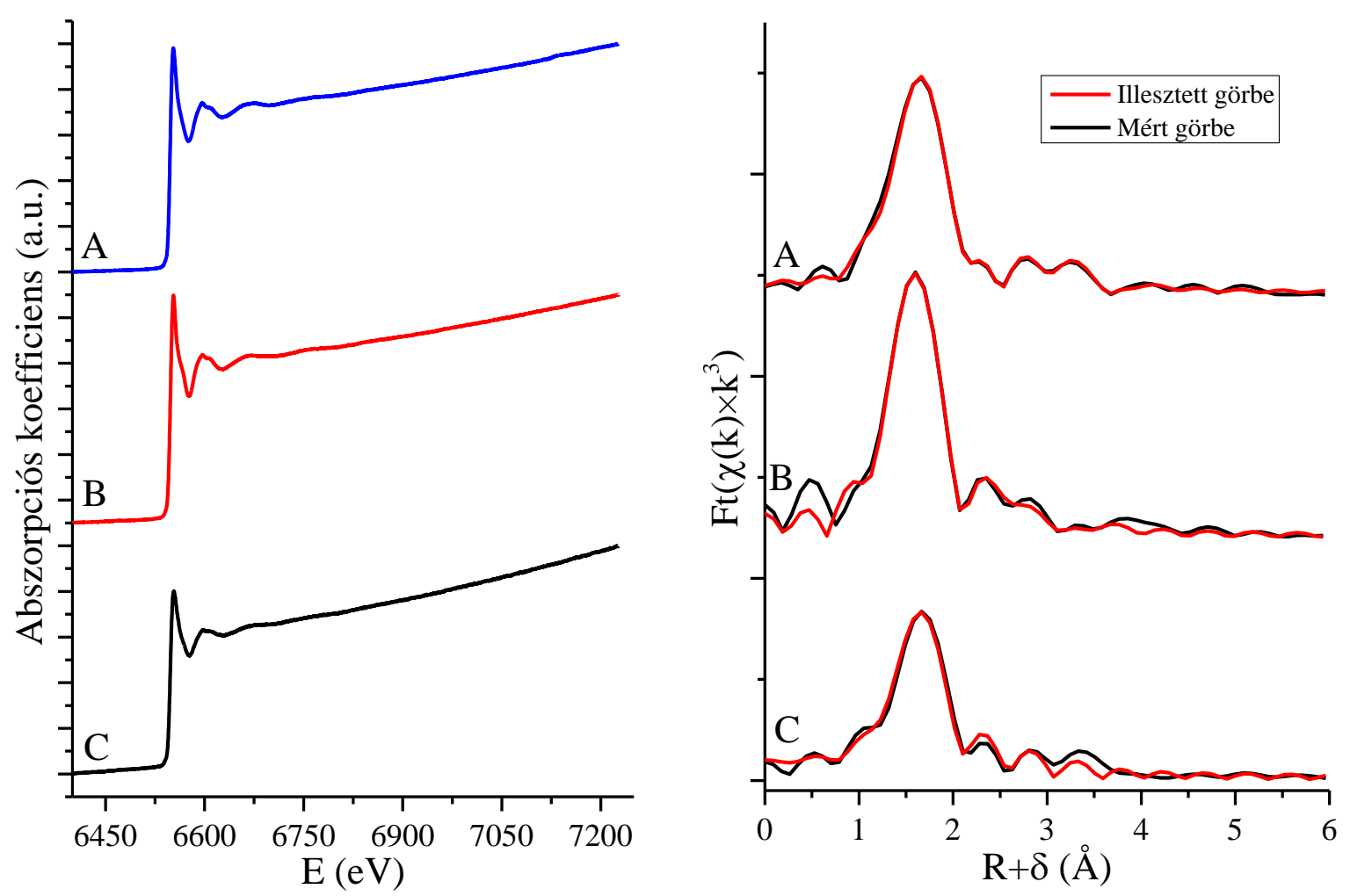

38. ábra: $\mathrm{Mn}(\mathrm{II})$-aminosav-LDH kompozitok XAS spektrumai (a) és radiális eloszlásai (b); $\mathrm{A}$ : Mn(II)-ciszteinát-CaAl-LDH; B: CaAl-Mn(II)-hisztidinát-LDH; C: Mn(II)-tirozinát-CaAl-LDH.

Az illesztés során mind a hisztidinát-, mind a ciszteináttartalmú minták esetében rendelkezésre álltak a távoli IR, valamint az ESR mérések eredményei.

Az ESR paraméterek alapján a ligandumok egy-, illetve kétfogú módon koordinálnak a Mn(II) ionhoz mindkét komplex esetén. A távoli IR mérések eredményei alapján a hisztidináttartalmú minta esetében az imidazolát nitrogén, valamint az amino nitrogén koordinációját lehetett feltételezni, illetve azt, hogy vízmolekula/molekulák vesz/vesznek részt a koordinációban. A kvantitatív elemzés azt mutatta, hogy 2:1 aminosav:fém ion aránnyal kell számolni. Az illesztés a legjobb akkor volt, amikor az elsődleges koordinációs szférába 2,19 Å távolságra a központi iontól hat darab $\mathrm{O} / \mathrm{N}$ atomot helyeztem (7. táblázat). Két dolgot még itt meg kell jegyeznem. Egyrészt ez a technika nem képes különbséget tenni oxigén-, illetve nitrogénatom között. A másik fontos dolog az, hogy a táblázatokban csak a koordinálódó atomokat és azok távolságát a központi iontól adtuk meg, de az illesztés során a ,járulékos” atomokat, vagyis az aminosav szénláncának többi atomját is megillesztettük, hiszen ezek is szórják a röntgen fotonokat. Tehát a legjobb illesztéshez 2:1 összetételü komplexek feltételezése kellett, amelyben mindkét ligandum kétfogú módon koordinálódik. Mindkét aminosav esetében az amino nitrogén és az imidazolát nitrogén koordinációját tételeztük fel a távoli IR spektroszkópiai vizsgálatok 
alapján. A maradék két helyet a koordinációs szférában pedig a víz töltötte ki a modellben. Így sikerült elérni 12,2 \%-os F faktor értéket. Ha 3:1 összetételü komplexeket (az ESR spektrumokból ilyen komplexek jelenlétét is fel lehetett tételezni) is belevettük az illesztésbe, már csak 10 \%-os valószínüséggel is, akkor az $\mathrm{F}$ faktor értéke 32,1\%-ra ugrott, ami kívül esik a jónak számító illesztés határán. Ha a ligandumok koordináló donorcsoportjait cseréltük le, azaz belevettük a karboxilát ion koordinációját is a modellbe, akkor is $20 \%$-nál nagyobb $\mathrm{F}$ faktort kaptam. A modell helyességét irodalmi analógiák is alátámasztották. ${ }^{195}$

7. táblázat: A mangántartalmú LDH kompozitok XAS spektrumainak illesztett paraméterei $(\mathrm{N}$ : koordinációs szám; R: interatomos távolság, $\sigma^{2}$ : Debye-Waller factor; $\mathrm{F}$ faktor: az illesztés jósága).

\begin{tabular}{cccccc}
\hline $\begin{array}{c}\text { CaAl-LDH } \\
\text { kompozitok }\end{array}$ & $\mathrm{Mn}(\mathrm{II})-\mathrm{X}$ & $\mathrm{N}$ & $\mathrm{R}(\AA)$ & $\sigma^{2}\left(\AA^{2}\right)$ & $\mathrm{F}$ faktor $(\%)$ \\
\hline Mn(II)-Tyr & $\mathrm{N} / \mathrm{O}$ & 6 & 2,18 & 0,0045 & 19,7 \\
Mn(II)-Cys & $\mathrm{N} / \mathrm{O}$ & 4 & 2,16 & 0,0075 & 8,4 \\
& $\mathrm{~S}$ & 2 & 2,57 & 0,0173 & \\
Mn(II)-His & $\mathrm{N} / \mathrm{O}$ & 6 & 2,19 & 0,01139 & 12,2 \\
\hline
\end{tabular}

A ciszteináttartalmú minta esetében 2:1 (esetleg 3:1) összetételü oktaéderes komplexek beépülését lehetett feltételezni a kvantitatív analízis és az ESR spektrumok eredményei alapján. A ligandumok feltételezhetően a tiolát kénatomjukkal (Raman spektrum alapján), valamint az amino nitrogénjükkel egy- vagy kétfogú ligandumként koordinálódnak (ESR spektrum alapján). Továbbá két vízmolekula koordinációja is feltételezhető a távoli IR spektrum alapján. Ezzel a modellel kiemelkedően jó, 8,4 \%-os $F$ faktor értéket kaptam, ami azt jelenti, hogy a modell szinte tökéletesen leírja a mért görbét, és jól egyezik a korábbi irodalmi adatokkal is. ${ }^{196}$ A karboxilát oxigén koordinációját nem volt szükséges feltételezni. Mivel ezek a csoportok hordozzák a negatív töltést, ezért szerepük az, hogy a rétegekkel ionos jellegü kötést kialakítva a komplexet a rétegek között tartsa.

A tirozináttartalmú minta esetében csak annyit lehetett előzetesen tudni, hogy 2:1 összetételü komplexekkel kell számolni, és azt, hogy egy vagy két molekulányi víz biztosan részt vesz a koordinációban. Irodalmi eredményekre támaszkodva ${ }^{197}$, a karboxilát oxigén, valamint az amino nitrogének koordinációját feltételezve megfelelően leírható volt a rendszer (az F faktor 19,7 \%-nak adódott). 

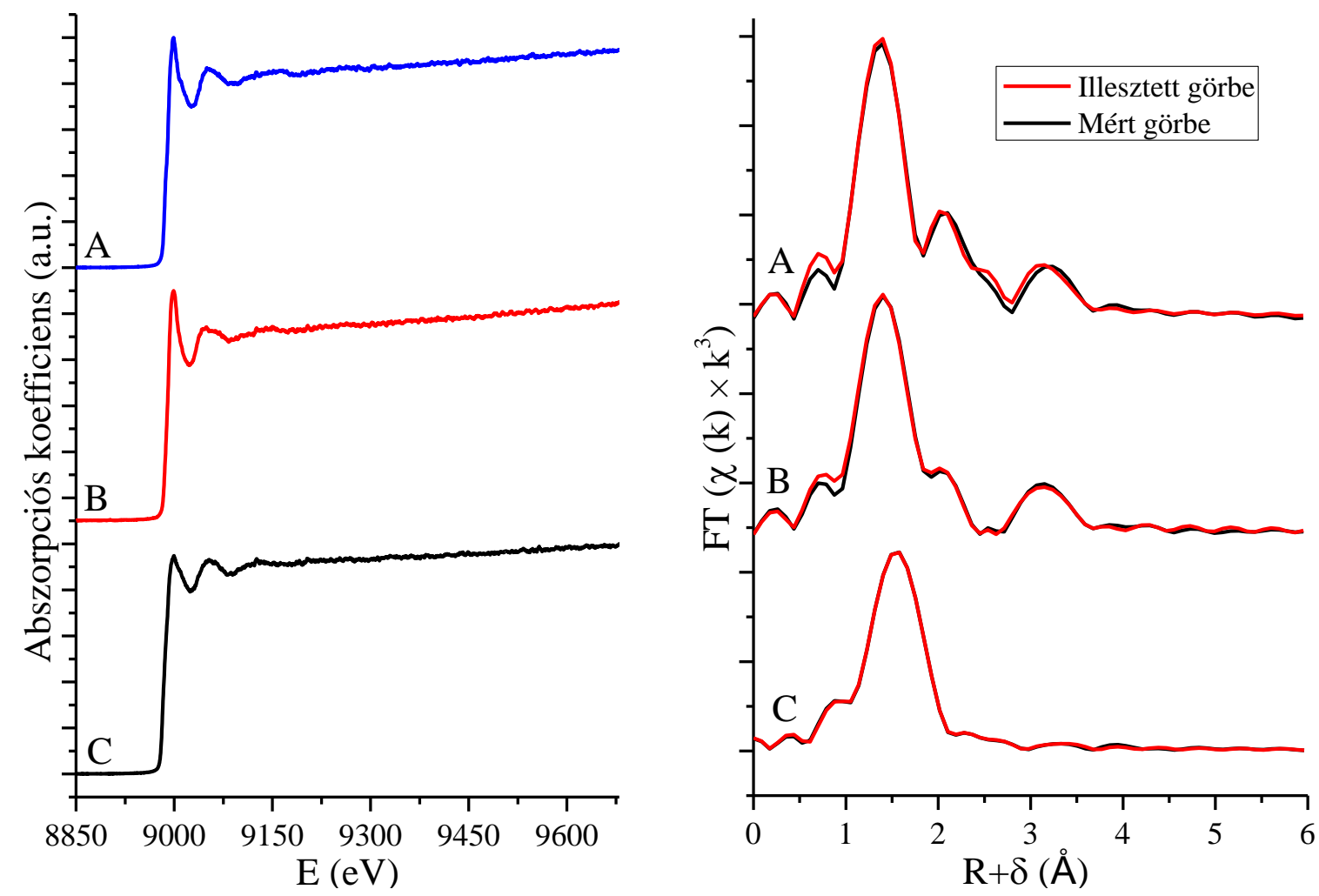

39. ábra: $\mathrm{Cu}(\mathrm{II})$-aminosav-LDH kompozitok XAS spektrumai (a) és radiális eloszlásai (b); $\mathrm{A}$ : $\mathrm{Cu}$ (II)-tirozinát-CaAl-LDH; B: Cu(II)-hisztidinát-CaAl-LDH; C: CaAl-Cu(II)-ciszteinát-LDH.

A réz-aminosav komplexekkel interkalált LDH XAS spektrumaiban a $\mathrm{K}$ héjhoz tartozó átmenet 8993,49 eV-nál található. Ez, összehasonlítva a nulla oxidációs állapothoz tartozó 8987,96 \pm 0,15 eV-tal, azt jelenti, hogy az összes esetben a réz plusz kettes oxidációs állapotot vett fel. ${ }^{173}$ Mivel nem látható átmenet a XANES tartományban, így kijelenthető, hogy a komplexek oktaéderes szerkezetüek (39. ábra).

8. táblázat: A réztartalmú LDH-kompozitok XAS spektrumainak illesztett paraméterei $(\mathrm{N}$ : koordinációs szám; R: interatomos távolság, $\sigma^{2}$ : Debye-Waller factor; $F$ faktor: az illesztés jósága).

\begin{tabular}{cccccc}
\hline CaAl-LDH kompozitok & $\mathrm{Cu}(\mathrm{II})-\mathrm{X}$ & $\mathrm{N}$ & $\mathrm{R}(\AA)$ & $\sigma^{2}\left(\AA^{2}\right)$ & F faktor $(\%)$ \\
\hline \multirow{2}{*}{$\mathrm{Cu}(\mathrm{II})-\mathrm{Cys}$} & $\mathrm{N} / \mathrm{O}$ & 2 & 2,009 & 0,005350 & \multirow{2}{*}{3,86} \\
& $\mathrm{~S}$ & 2 & 1,969 & 0,89470 & \\
& $\mathrm{~N} / \mathrm{O}$ & 2 & 2,123 & 0,005130 & \\
\hline \multirow{2}{*}{$\mathrm{Cu}(\mathrm{II})-\mathrm{His}$} & $\mathrm{N} / \mathrm{O}$ & 4 & 1,939 & 0,006860 & \multirow{2}{*}{$\mathrm{N}, 10$} \\
& $\mathrm{~N} / \mathrm{O}$ & 2 & 2,330 & 0,012750 & \multirow{2}{*}{$\mathrm{N} / \mathrm{O}$} \\
\multirow{2}{*}{$\mathrm{Cu}(\mathrm{II})-\mathrm{Tyr}$} & $\mathrm{N} / \mathrm{O}$ & 2 & 2,949 & 0,004416 & \multirow{2}{*}{} \\
& & & & &
\end{tabular}

A Cu(II)-t tartalmazó minták esetében tulajdonképpen az ESR és távoli IR mérések alapján már készen volt egy modell, amit csak meg kellett illesztenünk. Különösen igaz ez a hisztidinátot és ciszteinátot tartalmazó komplexekre, ahol ESR méréseken alapuló irodalmi analógiákkal megadtunk egy-egy lehetséges koordinációt: $\mathrm{Cu}(\mathrm{II})$-His: 
$\mathrm{N}_{\text {imidazolát }} \mathrm{N}_{\text {amino }} \mathrm{N}_{\text {amino }} \mathrm{O}_{\text {karboxilát, }} \quad \mathrm{Cu}\left(\right.$ II)-Cys: $\mathrm{S}_{\text {tiolát }} \mathrm{S}_{\text {tiolát }} \mathrm{N}_{\text {amino }} \mathrm{N}_{\text {amino. }}$ Ha $2: 1$ összetételü komplexeket, oktaéderes elrendeződést és két víz molekula koordinációját feltételezve nagyon jó illesztést sikerült elérnünk (8. táblázat). A tirozináttartalmú minta esetében, ha az összetételt 2:1-nek vettük, a fenolát oxigén és az amino nitrogén koordinációját kellett feltételezni ahhoz, hogy jól leírható legyen a rendszer (14,63\%-os F faktor). Még jobb illesztést kaptam, ha a karboxilát oxigén és az amino nitrogén koordinációját feltételeztem $(7,73 \%)$, korábbi irodalmi adatok alapján. ${ }^{198}$ A Jahn-Teller torzulás hatására ebben az esetben feltételezhetően a vízmolekulák oxigénjei megkülönböztethető távolságban helyezkedtek el a többi $\mathrm{O} / \mathrm{N}$ atomhoz képest. A torzulásnak olyan érdekes hozománya is volt, hogy a ciszteinát esetében a tiolát kénatomok az $x$ (vagy $y$ ) tengely írányából koordinálódtak rézcentrumhoz, mivel így kevésbé feszült szerkezet alakult ki, mintha a kén atomok a $z$ tengely irányába álltak volna, és így azok szenvedték volna el a torzulást.
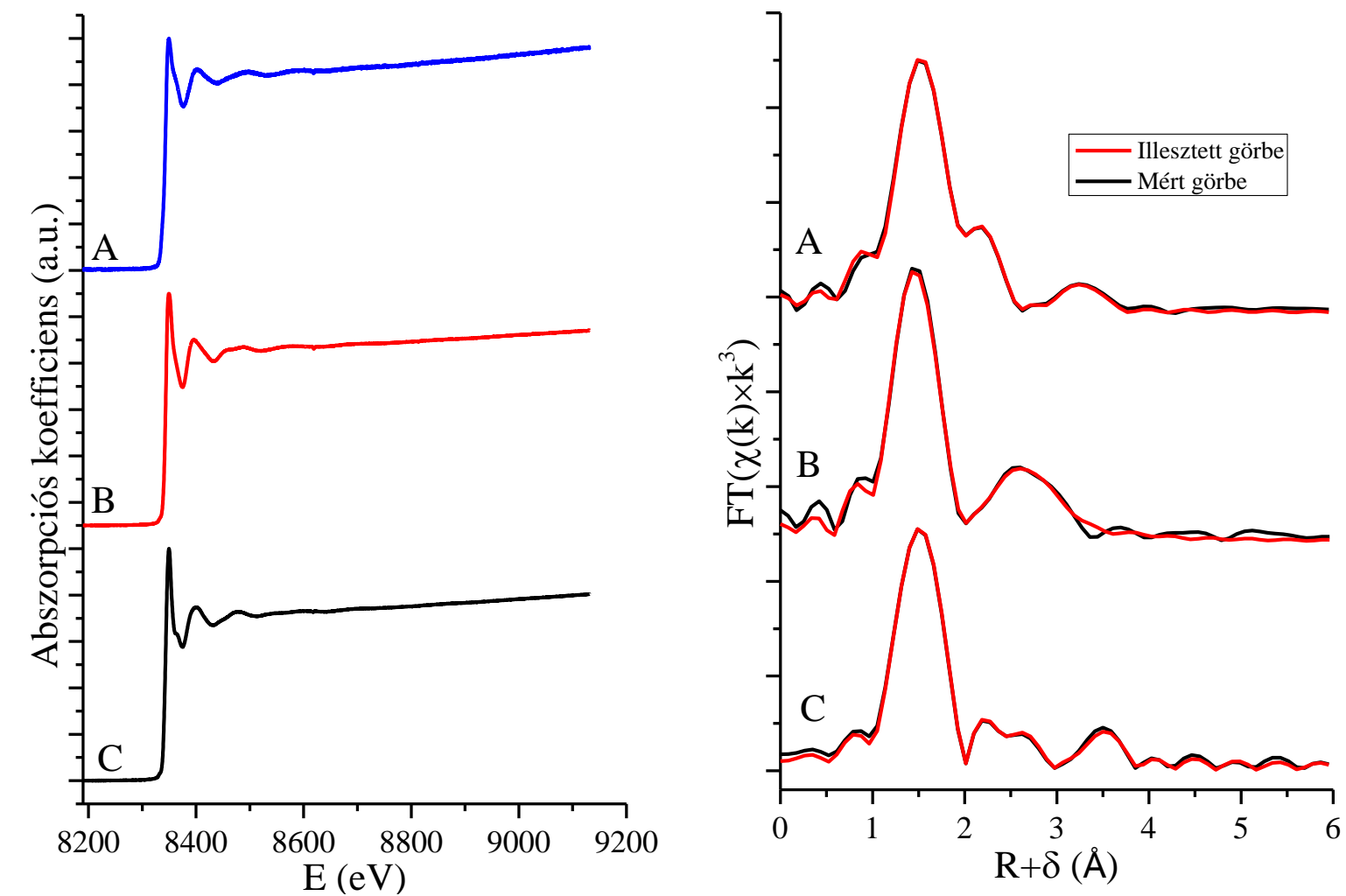

40. ábra: Ni(II)-aminosav-LDH kompozitok XAS spektrumai (a) és radiális eloszlásai (b); A: CaAl-Ni(II)-ciszteinát-LDH; B: CaAl-Ni(II)-tirozinát-LDH; C: Ni(II)-hisztidinát-CaAl-LDH.

A nikkeltartalmú kompozitoknál az XAS spektrumon látható átmenet 8350,01 eVnál látható (40. ábra). Ez azt jelenti, hogy a nikkel +2-es oxidációs állapotú a komplexekben (atomos oxidációs állapot esetén ez 8347,42 $\pm 0,14 \mathrm{eV}$ lett volna). ${ }^{173} \mathrm{~A}$ XANES régióban az átmenet hiánya azt jelenti, hogy a komplexek oktaéderes szerkezetűek. 
9. táblázat: A nikkeltartalmú LDH-kompozitok XAS spektrumainak illesztett paraméterei $(\mathrm{N}$ : koordinációs szám; R: interatomos távolság; $\sigma^{2}$ : Debye-Waller factor; $F$ faktor: az illesztés jósága).

\begin{tabular}{cccccc}
\hline $\begin{array}{c}\text { CaAl-LDH } \\
\text { kompozitok }\end{array}$ & Ni(II)-X & $N$ & $R(\AA)$ & $\sigma^{2}\left(\AA^{2}\right)$ & $\begin{array}{c}\text { F faktor } \\
(\%)\end{array}$ \\
\hline \multirow{2}{*}{$\mathrm{Ni}(\mathrm{II})-\mathrm{Tyr}$} & $\mathrm{N} / \mathrm{O}$ & 4 & 2,02 & 0,0085 & 11,5 \\
& $\mathrm{~N} / \mathrm{O}$ & 2 & 2,40 & 0,025 & \\
\hline \multirow{2}{*}{$\mathrm{Ni}(\mathrm{II})-\mathrm{Cys}$} & $\mathrm{N} / \mathrm{O}$ & 2 & 2,03 & 0,0039 & \\
& $\mathrm{~N} / \mathrm{O}$ & 2 & 2,25 & 0,0679 & \multirow{2}{*}{11,3} \\
& $\mathrm{~S}$ & 2 & 2,66 & 0,0091 & \\
\multirow{2}{*}{$\mathrm{Ni}(\mathrm{II})-\mathrm{His}$} & $\mathrm{N} / \mathrm{O}$ & 2 & 1,95 & 0,0039 & \multirow{2}{*}{6,8} \\
\hline
\end{tabular}

Az amino nitrogén és két vízmolekula koordinációját az összes esetben feltételezni kellett ahhoz, hogy megfelelően le tudjuk írni a mért spektrumokat (9. táblázat). A Raman spektrumok által szolgáltatott információkra alapozva a ciszteinát esetében a tiolát kén atom koordinációját is feltételeztük az illesztés során. A hisztidinát esetén szükséges volt az imidazolát nitrogén koordinálódásának a feltételezése. Ugyanakkor ugyanolyan jó illesztést kaptam, ha az egyik ligandum esetében (a réz-tartalmú mintához hasonlóan) az egyik karboxilát oxigén koordinációját feltételeztem az imidazolát nitrogén helyett. Az irodalomban találunk példát $\mathrm{N}_{\text {imidazolát }} \mathrm{N}_{\text {amino }} \mathrm{N}_{\text {amino }} \mathrm{O}_{\text {karboxilát koordinációs szféra }}$ kialakulására, ahol a víz is részt vesz a koordinációs szférában. Igaz ebben az esetben mindkét imidazolát nitrogén koordinálódik, de ez a rétegek között vélhetően nem lehetséges. ${ }^{199}$ A tirozinátnál pedig a fenolát oxigén vagy a karboxilát oxigén koordinációját is figyelembe kellett venni, és ebben az esetben is a karboxilát csoport koordinációjának az illesztése szolgáltatta a legjobb eredményt (11,5\%). Irodalmi analógiák alapján valószínűsítettem a karboxilát oxigén koordinációját. ${ }^{200}$ Minden esetben 2:1 összetételü komplexekkel kellett számolni. Így jó közelítéssel le lehetett írni a spektrumokat. A JahnTeller torzulás ebben az esetben is szerepet játszik, hiszen például a hisztidinát esetében legalább két különböző távolságú $\mathrm{O} / \mathrm{N}$ koordinációjával kellett számolni. Az viszont jól látható, hogy a torzulás nem olyan jelentős, mint a $\mathrm{Cu}$ (II)-tartalmú minták esetében, mivel ebben az esetben a tiolát kén atom képes volt elhelyezkedni a Z-tengely irányában. 

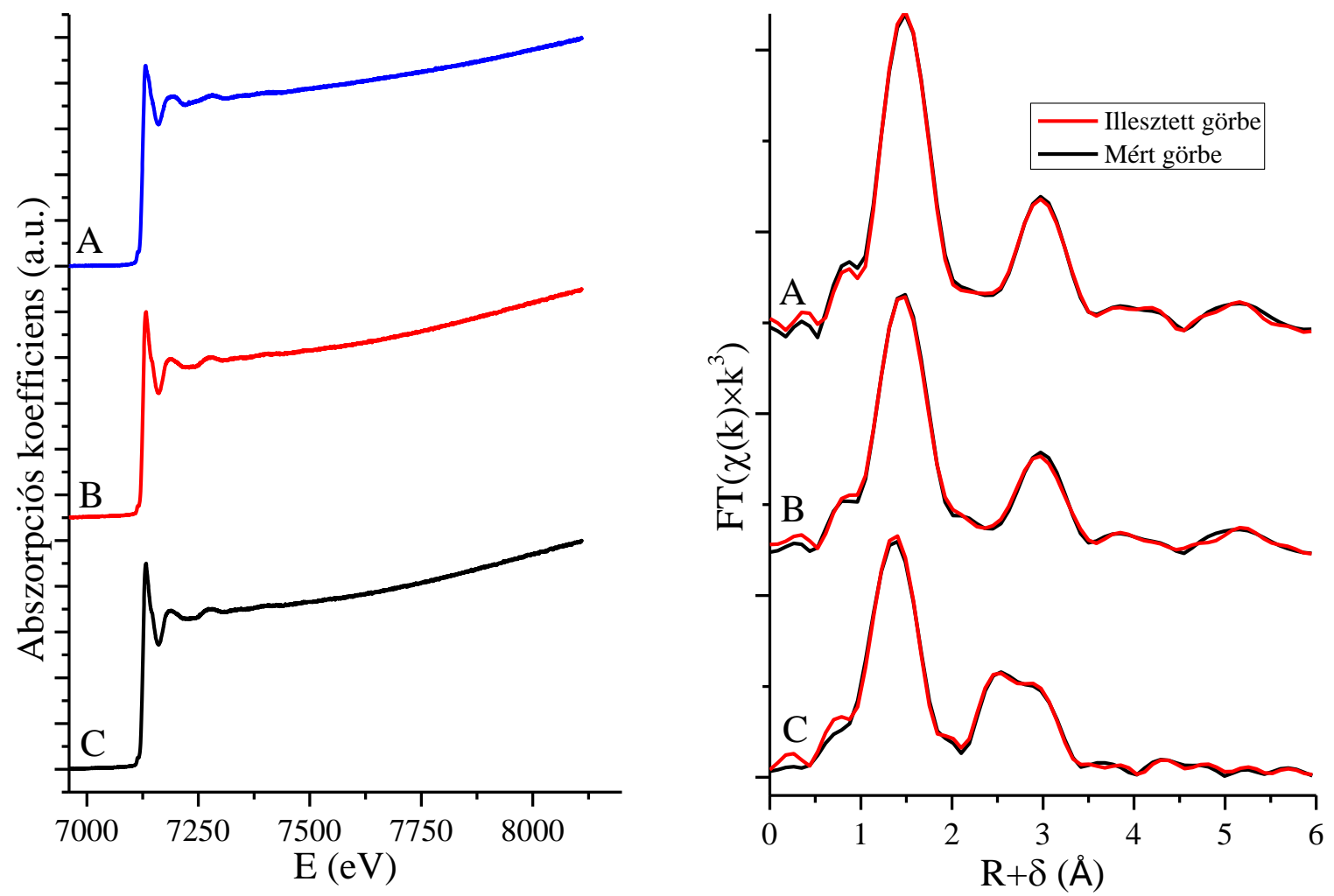

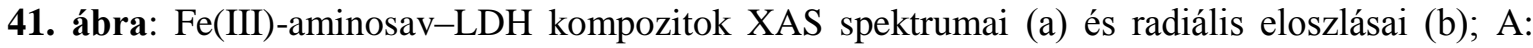
Fe(III)-tirozinát-CaAl-LDH; B: Fe(III)-hisztidinát-CaAl-LDH; C: CaAl-Fe(III)-ciszteinát-LDH.

Az XAS spektrumokból kiderült a vastartalmú minták esetében is, hogy oktaéderes elrendeződéssel kell számolni, mert itt sem volt átmenet a XANES régióban (41. ábra) egyik kompozit esetében sem. A K héjhoz tartozó átmenet 7133,05 eV-nál található a spektrumokban, ami azt jelenti, hogy +3 -as oxidációs állapotban van a vas az interkalált komplexben (atomos állapot esetén: 7125,87 $\pm 0,13 \mathrm{eV}) .{ }^{173}$

10. táblázat: A vastartalmú LDH-kompozitok XAS spektrumainak illesztett paraméterei $(\mathrm{N}$ : koordinációs szám; R: interatomos távolság; $\sigma^{2}$ : Debye-Waller factor; $F$ faktor: az illesztés jósága).

\begin{tabular}{|c|c|c|c|c|c|}
\hline $\begin{array}{l}\text { CaAl-LDH } \\
\text { kompozitok }\end{array}$ & $\mathrm{Fe}(\mathrm{III})-\mathrm{X}$ & $\mathrm{N}$ & $\mathrm{R}(\AA)$ & $\sigma^{2}\left(\AA^{2}\right)$ & $\begin{array}{c}\mathrm{F} \text { faktor } \\
(\%)\end{array}$ \\
\hline \multirow{2}{*}{$\mathrm{Fe}(\mathrm{III})-\mathrm{Tyr}$} & $\mathrm{N} / \mathrm{O}$ & 4 & 2,00 & 0,0091 & \multirow{2}{*}{10,5} \\
\hline & $\mathrm{N} / \mathrm{O}$ & 2 & 2,18 & 0,014 & \\
\hline \multirow{3}{*}{$\mathrm{Fe}(\mathrm{III})-\mathrm{Cys}$} & $\mathrm{N} / \mathrm{O}$ & 2 & 1,98 & 0,0043 & \multirow{3}{*}{14,5} \\
\hline & N/O & 2 & 2,17 & 0,0071 & \\
\hline & $\mathrm{S}$ & 2 & 2,36 & 0,0091 & \\
\hline \multirow{2}{*}{$\mathrm{Fe}(\mathrm{III})$-His } & $\mathrm{N} / \mathrm{O}$ & 4 & 1,96 & 0,0035 & \multirow{2}{*}{10,6} \\
\hline & N/O & 2 & 2,16 & 0,0099 & \\
\hline
\end{tabular}

A $\mathrm{Fe}(\mathrm{III})$ közvetlen környezetének a leírásához hasonló szerkezeteket kellett feltételeznünk, mint a Ni(II)-tartalmú minták esetében. Vagyis az amino nitrogének az összes esetben részt vesznek a koordinációban, valamint a fenolát oxigén vagy a karboxilát 
oxigén a tirozináttartalmú minta esetén, az imidazolát nitrogén (vagy a karboxilát oxigén) a hisztidinát esetében, valamint a tiolát kén a ciszteinát esetében szintén megtalálható az elsődleges koordinációs szférában (10. táblázat). Az illesztett modellek ebben az esetben is jó egyezést mutattak a mért adatokkal.

\subsubsection{Az interkalált komplexek feltételezett szerkezete}

Az interkalált komplex anion feltételezett szerkezetét ezek után már meg tudtuk adni. Irodalmi röntgenadatok alapján felvettük az LDH vázat, és a rétegei közé úgy helyeztük el az aminosav komplex aniont, hogy annak a szerkezete és az interatomos távolságok megegyezzenek az XAS eredményeivel. A rétegtávolságokat és a komplex anionok dimenzióit a 11. táblázatban gyüjtöttük össze.

11. táblázat: A sikeresen beépített komplexek és a CaAl-LDH dimenziói.

\begin{tabular}{lccc}
\hline $\begin{array}{c}\text { CaAl-LDH } \\
\text { kompozitok }\end{array}$ & Rétegtávolság $(\mathrm{d})(\mathrm{nm})$ & $\begin{array}{c}\text { Rétegközi tér } \\
(\mathrm{nm})\end{array}$ & $\begin{array}{c}\text { A komplexek dimenziói } \\
(\mathrm{nm})\end{array}$ \\
\hline $\mathrm{Mn}(\mathrm{II})-\mathrm{Cys}$ & 0,921 & 0,687 & $0,447 \times 0,447 \times 0,959$ \\
$\mathrm{Mn}(\mathrm{II})-\mathrm{His}$ & 0,929 & 0,695 & $0,697 \times 0,496 \times 1,030$ \\
$\mathrm{Mn}(\mathrm{II})-\mathrm{Tyr}$ & 0,859 & 0,625 & $0,660 \times 0,475 \times 1,238$ \\
\hline $\mathrm{Cu}$ (II)-Cys & 0,949 & 0,715 & $0,717 \times 0,452 \times 0,969$ \\
$\mathrm{Cu}(\mathrm{II})-\mathrm{His}$ & 0,857 & 0,623 & $0,627 \times 0,505 \times 1,020$ \\
$\mathrm{Cu}$ (II)-Tyr & 1,110 & 0,876 & $0,871 \times 0,495 \times 1,045$ \\
\hline $\mathrm{Ni}$ (II)-Cys & 0,873 & 0,639 & $0,647 \times 0,440 \times 0,974$ \\
$\mathrm{Ni}(\mathrm{II})-H i s$ & 0,919 & 0,685 & $0,684 \times 0,500 \times 1,027$ \\
$\mathrm{Ni}(\mathrm{II})-\mathrm{Tyr}$ & 0,873 & 0,639 & $0,637 \times 0,487 \times 1,055$ \\
\hline $\mathrm{Fe}(\mathrm{III})-\mathrm{Cys}$ & 0,883 & 0,649 & $0,645 \times 0,445 \times 0,981$ \\
$\mathrm{Fe}(\mathrm{III})-H i s$ & 1,039 & 0,805 & $0,793 \times 0,507 \times 1,005$ \\
$\mathrm{Fe}(\mathrm{III})-\mathrm{Tyr}$ & 1,014 & 0,780 & $0,770 \times 0,495 \times 1,025$ \\
\hline
\end{tabular}

Minden egyes esetben sikerült úgy elhelyezni a komplexeket, hogy ne jöjjön létre túlzottan feszült szerkezet. A Mn(II)-tartalmú minták (42. ábra) esetében megpróbáltunk egy olyan szerkezetet elhelyezni, amelyben három ligandum koordinál, de ez sztérikus okok miatt sikertelen volt. Vélhetően, ha van is 3:1 összetételü komplex a rendszerben, annak mennyisége 10\%-nál kisebb, és nagy valószínűséggel a felületen megkötődve található. 


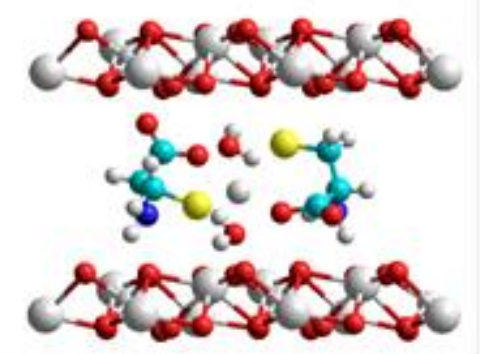

Mn(II)-ciszteinát-CaAl-LDH

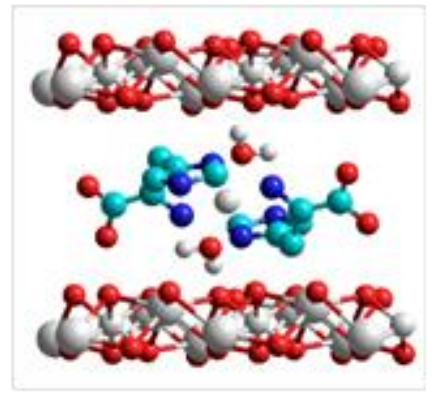

CaAl-Mn(II)-hisztidinát-LDH

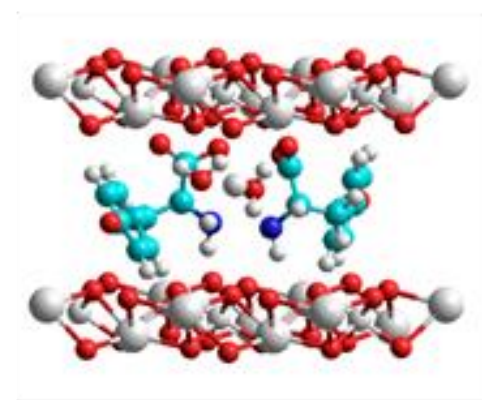

Mn(II)-tirozinát-CaAl-LDH

42. ábra: Mn(II)-aminosav-LDH kompozitok legvalószínúbb elhelyezkedése a rétegek között.

A réztartalmú minták ábráin megfigyelhetjük, hogy a legtöbb esetben a karboxilát oxigének lépnek kölcsönhatásba a rétegekkel, és ezek tartják ionos kölcsönhatásokkal az LDH rétegközi terében az aminosav komplexeket (43. ábra). Jól látható, hogy a szerkezet optimalizálása során a $\mathrm{Cu}(\mathrm{II})$-Tyr rendszer esetén a nagymértékben megnövekedett rétegtávolságok is illeszthetők voltak. A tirozinát fenolgyürüjének síkjára merőlegesen épültek be a komplexek, és így támasztották ki a rétegeket. Az is kiderült, hogy sztérikus okok miatt az amino nitrogén és a fenolát oxigén nem vehet egyszerre részt a koordinációban - igaz ez az állítás a vas- és nikkeltartalmú rendszerekre is. Ez tehát azt jelenti, hogy az összes tirozináttartalmú rendszernél (kivéve a Mn(II)-tartalmú rendszert) a karboxilát oxigén vesz részt a koordinációban.

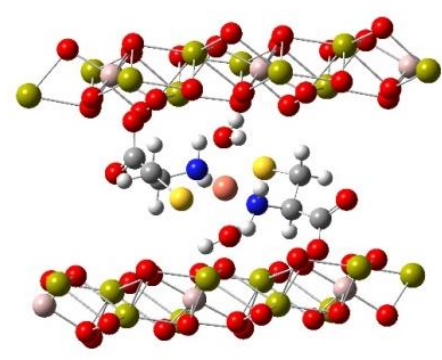

CaAl-Cu(II)-ciszteinát-LDH

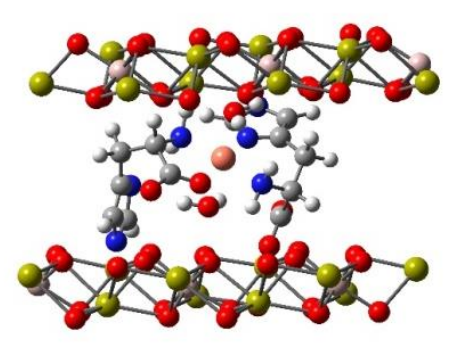

$\mathrm{Cu}(\mathrm{II})$-hisztidinát-CaAl-LDH

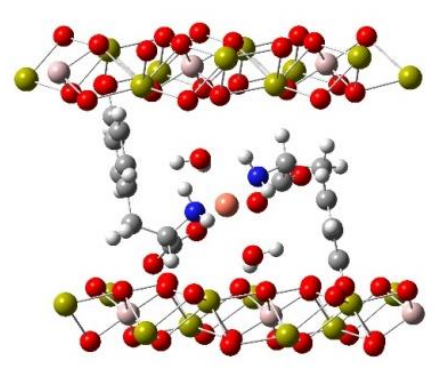

$\mathrm{Cu}(\mathrm{II})$-tirozinát-CaAl-LDH

43. ábra: $\mathrm{Cu}(\mathrm{II})$-aminosav-LDH kompozitok legvalószínübb elhelyezkedése a rétegek között.

A Ni(II)-His (44. ábra) és Cu(II)-His (43. ábra), valamint a Fe(III)-His (45. ábra) rendszerek esetében kiderült, hogy csak abban az esetben lehet elhelyezni a rétegek közé a komplexet, ha a karboxilát oxigének is koordinálódnak az egyik ligandum esetén. Ugyanakkor ebben az esetben is képes a komplex a rétegek között maradni, hiszen a másik karboxilát és az imidazol nitrogén nemkötő elektronpárja is szerepet játszhat a komplex anionok rétegek közötti tartásában. 


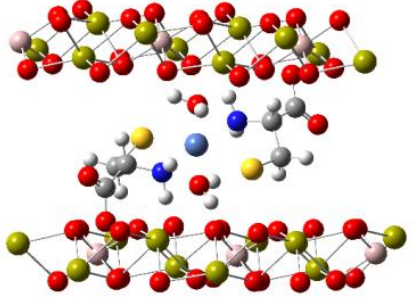

CaAl-Ni(II)-ciszteinát-LDH

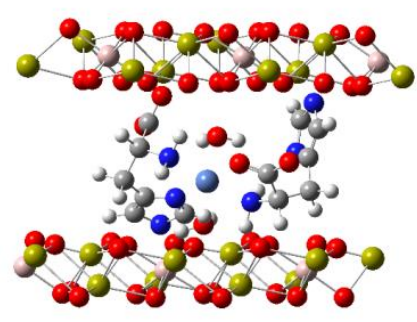

Ni(II)-hisztidinát-CaAl-LDH

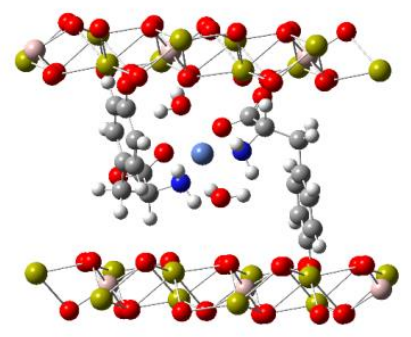

$\mathrm{Ni}(\mathrm{II})$-tirozinát-CaAl-LDH

44. ábra: Ni(II)-aminosav-LDH kompozitok legvalószínübb elhelyezkedése a rétegek között.

A Fe(III)-tartalmú rendszerek esetében próbát tettünk a cisztinát (azt a lehetőséget feltételezve, hogy a ciszteinát ionok cisztináttá oxidálódnak) koordinációjának az illesztésére, de sehogy sem sikerült ilyen rendszereket a rétegek közé elhelyezni, összhangban azzal, hogy a Raman mérések sem utaltak cisztinát ion megjelenésére.

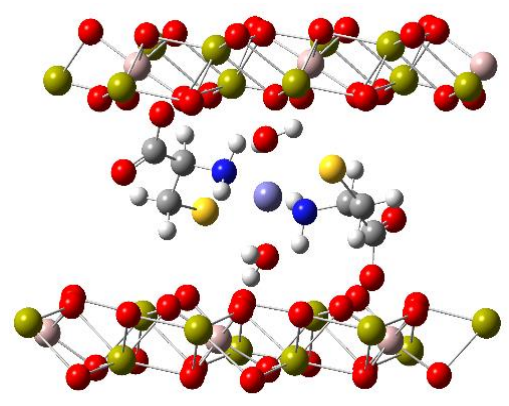

$\mathrm{CaAl}-\mathrm{Fe}(\mathrm{III})$-ciszteinát-LDH

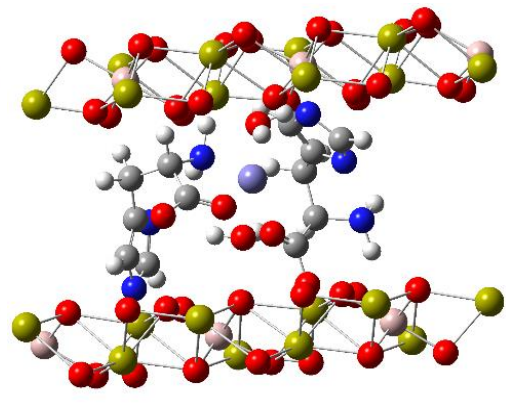

Fe(III)-hisztidinát-CaAl-LDH

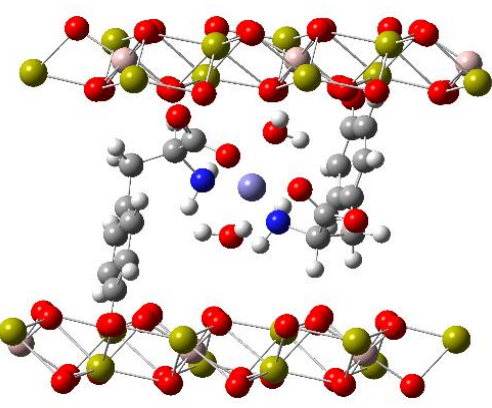

Fe(III)-tirozinát-CaAl-LDH

45. ábra: $\mathrm{Fe}(\mathrm{III})$-aminosav-LDH kompozitok legvalószínűbb elhelyezkedése a rétegek között.

\subsection{A katalitikus aktivitás vizsgálata}

Az előállított kompozitokat különféle oxidációs reakciókban, illetve a $\mathrm{Cu}(\mathrm{II})$ - és Fe(III)-tartalmúakat az Ullmann-féle kapcsolási reakcióban is, a rekaciókörülmények szisztematikus változtatásával teszteltük. Minden esetben vizsgáltuk a kompozitok újrahasznosíthatóságát is. A részletes eredmények megelőlegezéseként elmondhatjuk, hogy a kompozitok recirkulációs sajátságai jók voltak, azaz katalizátorként müködtek.

A rekaciókörülmények változtatásának hatásait csak a ciklohexén oxidációján keresztül mutatjuk be részletesen, és ebben az esetben is a Mn(II)-tartalmú rendszerekre fogunk koncentrálni.

\subsubsection{A ciklohexén oxidációja}

Az első lépésben a katalizátor mennyiségét változtattuk annak érdekében, hogy a rendszer a diffúziós tartományból a kinetikai tartományba kerüljön. 
A 12. táblázat adataiból látható, hogy $5 \mathrm{mg}$ kompozit alkalmazása esetén még nem történt semmilyen reakció. Ám 15 mg-ról 25 mg-ra növelve a kompozit mennyiségét a konverzió körülbelül megduplázódott. Tovább növelve a kompozit mennyiségét 35 mg-ra már nem növekedett a konverzió szignifikánsan, így a 25 mg-ot választottuk optimális katalizátormennyiségnek. A legnagyobb aktivitású a hisztidináttartalmú minta volt.

12. táblázat: A katalizátor mennyiségének hatása a ciklohexén konverziójára (aceton: $10 \mathrm{~cm}^{3}$, ciklohexén: $5 \mathrm{mmol}$, perecetsav: $2,5 \mathrm{mmol}$, hőmérséklet: $25^{\circ} \mathrm{C}$, reakcióidő: 1 óra).

\begin{tabular}{cccccc}
\hline CaAl-LDH & \multicolumn{5}{c}{ Konverzió (\%) } \\
\cline { 2 - 6 } kompozitok & $5 \mathrm{mg}$ & $15 \mathrm{mg}$ & $25 \mathrm{mg}$ & $35 \mathrm{mg}$ & $45 \mathrm{mg}$ \\
\hline Mn(II)-Tyr & - & 10 & 23 & 24 & 26 \\
Mn(II)-Cys & - & 8 & 18 & 20 & 22 \\
Mn(II)-His & - & 15 & 31 & 33 & 34 \\
\hline
\end{tabular}

A reakció elfogadható hozamokat produkálva megy $25{ }^{\circ} \mathrm{C}$-on, és mivel technikailag ezt könnyü biztosítani, így a továbbiakban is ezen a hőmérsékleten dolgoztunk.

A 13. táblázatban gyüjtöttük össze a különböző reakcióidőknél mért konverziókat. Látható, hogy 3 óra elteltével elértünk a telítési szakasz elejére, így a továbbiakban ezt a reakcióidőt alkalmaztuk.

13. táblázat: A reakcióidő hatása a ciklohexén konverziójára (katalizátor: $25 \mathrm{mg}$, aceton: $10 \mathrm{~cm}^{3}$; ciklohexén: $5 \mathrm{mmol}$; perecetsav: $2,5 \mathrm{mmol}$; hőmérséklet: $25^{\circ} \mathrm{C}$ ).

\begin{tabular}{cccccc}
\hline CaAl-LDH & \multicolumn{5}{c}{ Konverzió (\%) } \\
\cline { 2 - 6 } kompozitok & 1 óra & 3 óra & 6 óra & 12 óra & 24 óra \\
\hline Mn(II)-Tyr & 23 & 33 & 34 & 37 & 44 \\
Mn(II)-Cys & 18 & 40 & 42 & 43 & 46 \\
Mn(II)-His & 31 & 53 & 43 & 57 & 60 \\
\hline
\end{tabular}

Azt tapasztaltuk, hogy sem szerves, sem szervetlen peroxidokkal nem sikerült lejátszatni a reakciót (14. táblázat), ám diacetoxi-jódbenzol alkalmazásával jelentős volt a konverzió.

14. táblázat: A különböző oxidálószerek hatása a ciklohexén konverziójára (katalizátor: 25 mg; aceton: $10 \mathrm{~cm}^{3}$ (diacetoxi-jódbenzol esetén víz/aceton (5/95)); ciklohexén: $5 \mathrm{mmol}$; oxidálószer: 2,5 mmol; hőmérséklet: $25^{\circ} \mathrm{C}$; reakcióidő 3 óra).

\begin{tabular}{ccccc}
\hline CaAl-LDH & \multicolumn{4}{c}{ Konverzió (\%) } \\
\cline { 2 - 5 } kompozitok & Perecetsav & $\begin{array}{c}t \text {-Butil-hidro- } \\
\text { peroxid }\end{array}$ & Hidrogén-peroxid & $\begin{array}{c}\text { Diacetoxi- } \\
\text { jódbenzol }\end{array}$ \\
\hline Mn(II)-Tyr & 33 & - & - & 30 \\
Mn(II)-Cys & 40 & 4 & - & 37 \\
Mn(II)-His & 53 & 7 & 5 & 50 \\
\hline
\end{tabular}


Az oldószereket változtatva, azt figyeltük meg, hogy sem apoláris, sem poláris protikus oldószerekben nem, de acetonban és DMF-ben, azaz dipoláris aprotikus oldószerekben jól ment a reakció (15. táblázat).

15. táblázat: A különböző oldószerek hatása a ciklohexén konverziójára (katalizátor: $25 \mathrm{mg}$; oldószer: $10 \mathrm{~cm}^{3}$, ciklohexén: $5 \mathrm{mmol}$; perecetsav: $2,5 \mathrm{mmol}$; hőmérséklet: $25{ }^{\circ} \mathrm{C}$; reakcióidő: 3 óra).

\begin{tabular}{cccccc}
\hline CaAl-LDH & \multicolumn{5}{c}{ Konverzió (\%) } \\
\cline { 2 - 6 } kompozitok & Aceton & Etanol & Toluol & DMF & Víz \\
\hline Mn(II)-Tyr & 33 & 4 & - & 38 & 6 \\
Mn(II)-Cys & 40 & 7 & - & 39 & 3 \\
Mn(II)-His & 53 & 5 & - & 44 & 8 \\
\hline
\end{tabular}

Eddig csak a ciklohexén konverziójáról beszéltünk, de a termékekről nem. Ezzel kapcsolatban elmondható, hogy a Mn(II)-tartalmú minták nagyfokú epoxid szelektivitást mutattak (16. táblázat), sőt, a ciszteinát- és hisztidináttartalmú katalizátorokon kizárólag az epoxid képződött. A tirozináttartalmú mintán kapott transz-diol is minden valószínüség szerint az epoxid gyürünyitási terméke.

Amint azt már említettük, a katalizátorok recirkulációs sajátságai kiválóak voltak, sikeresen felhasználhatók voltak további három megismételt reakcióban anélkül, hogy aktivitásuk lényegesen csökkent volna (16. táblázat).

16. táblázat: A kiválasztott paraméterek mellett mért konverziók és szelektivitások perecetsav alkalmazása mellett (katalizátor: $25 \mathrm{mg}$, aceton: $10 \mathrm{~cm}^{3}$, ciklohexén: $5 \mathrm{mmol}$, perecetsav: 2,5 mmol, hőmérséklet: $25^{\circ} \mathrm{C}$, reakcióidő: 3 óra).

\begin{tabular}{ccccc|cc}
\hline CaAl-LDH & \multicolumn{3}{c|}{ TOF (1/h)/Konverzió (\%) } & \multicolumn{2}{c}{ Szelektivitás (\%) } \\
\cline { 2 - 7 } kompozitok & 1. felh. & 2. felh. & 3. felh. & 4. felh. & epoxid & transz-diol \\
\hline Mn(II)-Tyr & $31 / 33$ & $33 / 35$ & $31 / 33$ & $31 / 33$ & 79 & 21 \\
Mn(II)-Cys & $39 / 40$ & $39 / 40$ & $41 / 42$ & $42 / 43$ & 100 & 0 \\
Mn(II)-His & $50 / 53$ & $46 / 49$ & $44 / 47$ & $42 / 45$ & 100 & 0 \\
\hline
\end{tabular}

A diacetoxi-jódenzol használata során in situ dihidroxi-jódbezol keletkezik, amennyiben vizet adunk a rendszerhez (8. egyenlet). ${ }^{204}$ Valójában ez a molekula az oxidálószer.

$$
\mathrm{PhI}\left(\mathrm{OOCH}_{3}\right)_{2}+\mathrm{H}_{2} \mathrm{O} \leftrightarrows \mathrm{PhI}(\mathrm{OH})_{2}+2 \mathrm{CH}_{3} \mathrm{COOH}
$$

8. egyenlet: A diacetoxi-jódbenzol aktiválódása vizes közegben.

Már a 14. táblázat adatai megmutatták, hogy a dihidroxi-jódbenzol közel olyan konverziókat produkáló oxidálószer, mint a perecetsav. A 17. táblázat adataiból pedig 
egyértelmủen látható, hogy a katalizátorok újrahasznosíthatósága itt is nagyon jó volt. Világos az is, hogy ez az oxidálószer másként müködik, mint a perecetsav, hiszen a kis mennyiségü epoxid mellett főtermékként cisz-diolt kaptunk minden Mn(II)-tartalmú katalizátoron.

17. táblázat: A kiválasztott paraméterek mellett mért konverziók és szelektivitások diacetoxijódbenzol alkalmazása mellett (katalizátor: $25 \mathrm{mg}$, víz/aceton (5/95): $10 \mathrm{~cm}^{3}$; ciklohexén: $5 \mathrm{mmol}$; diacetoxi-jódbenzol: $2,5 \mathrm{mmol}$; hömérséklet: $25^{\circ} \mathrm{C}$; reakcióidő: 3 óra).

\begin{tabular}{ccccccc}
\hline CaAl-LDH & \multicolumn{3}{c}{ TOF (1/h)/Konverzió (\%) } & \multicolumn{2}{c}{ Szelektivitás (\%) } \\
\cline { 2 - 7 } kompozitok & 1. felh. & 2. felh. & 3. felh. & 4. felh. & epoxid & cisz-diol \\
\hline Mn(II)-Tyr & $28 / 30$ & $29 / 31$ & $25 / 27$ & $23 / 25$ & 12 & 88 \\
Mn(II)-Cys & $36 / 37$ & $28 / 29$ & $27 / 28$ & $27 / 28$ & 5 & 95 \\
Mn(II)-His & $47 / 50$ & $45 / 48$ & $42 / 45$ & $44 / 47$ & 7 & 93 \\
\hline
\end{tabular}

Az előbbiekben részletezett megállapítások érvényesek a $\mathrm{Cu}(\mathrm{II})-, \mathrm{Ni}(\mathrm{II})$ - és $\mathrm{Fe}(\mathrm{III})-$ tartalmú katalizátorokra is (néhány esetben nagyobb mennyiségü katalizátor és/vagy magasabb hőmérséklet, illetve reakcióidő alkalmazására volt szükség), amint azt a 18. és 19. táblázatok adatai mutatják.

18. táblázat: A különböző kompozitok aktivitása a ciklohexén oxidációjában perecetsav alkalmazása mellett (aceton: $10 \mathrm{~cm}^{3}$; ciklohexén: $5 \mathrm{mmol}$; perecetsav: $2,5 \mathrm{mmol}$ ).

\begin{tabular}{cccccc}
\hline $\begin{array}{c}\text { CaAl-LDH } \\
\text { kompozitok }\end{array}$ & $\begin{array}{c}\text { TOF (1/h)/ } \\
\text { konverzió } \\
(\%)\end{array}$ & $\begin{array}{c}\text { epoxid } \\
(\text { mol\% })\end{array}$ & $\begin{array}{c}\text { 2-chex-1-ol } \\
(\mathrm{mol} \%)\end{array}$ & $\begin{array}{c}\text { 2-chex-1-on } \\
(\mathrm{mol} \%)\end{array}$ & $\begin{array}{c}\text { transz- } \\
\text { diol } \\
(\mathrm{mol} \%)\end{array}$ \\
\hline- & $\mathrm{nr} / 18$ & 67 & 10 & 1 & 22 \\
$\mathrm{CaAl}-\mathrm{LDH}$ & $\mathrm{nr} / 18$ & 66 & 10 & 2 & 22 \\
\hline $\mathrm{Cu}(\mathrm{II})-\mathrm{Tyr}$ & $14 / 49$ & 97 & 0 & 1 & 2 \\
$\mathrm{Cu}(\mathrm{II})-\mathrm{Cys}$ & $20 / 47$ & 100 & 0 & 0 & 0 \\
$\mathrm{Cu}(\mathrm{II})-\mathrm{His}$ & $21 / 42$ & 98 & 0 & 0 & 2 \\
\hline $\mathrm{Ni}(\mathrm{II})-\mathrm{Tyr}$ & $67 / 30$ & 100 & 0 & 0 & 0 \\
$\mathrm{Ni}(\mathrm{II})-\mathrm{Cys}$ & $44 / 40$ & 100 & 0 & 0 & 0 \\
$\mathrm{Ni}(\mathrm{II})-\mathrm{His}$ & $31 / 47$ & 100 & 0 & 0 & 0 \\
\hline $\mathrm{Fe}(\mathrm{III})-\mathrm{Tyr}$ & $61 / 45$ & 88 & 0 & 0 & 12 \\
$\mathrm{Fe}(\mathrm{III})-\mathrm{Cys}$ & $77 / 51$ & 94 & 3 & 1 & 2 \\
$\mathrm{Fe}(\mathrm{III})-\mathrm{His}$ & $169 / 44$ & 100 & 0 & 0 & 0 \\
\hline $\mathrm{N}$ & & & & & \\
\hline
\end{tabular}

$\mathrm{Ni}(\mathrm{II}): 25 \mathrm{mg}$ katalizátor, $25{ }^{\circ} \mathrm{C}, 3$ óra.

$\mathrm{Cu}(\mathrm{II}): 35 \mathrm{mg}$ katalizátor, $25^{\circ} \mathrm{C}, 4$ óra.

$\mathrm{Fe}(\mathrm{III}): 50 \mathrm{mg}$ katalizátor, $40{ }^{\circ} \mathrm{C}, 6$ óra.

Perecetsav oxidálószer esetén a fő vagy sokszor kizárólagos termék az epoxid volt, különösen, ha az epoxid mennyiségéhez hozzávesszük a belőle származó transz-diolt is. 
Dihidroxi-jódbenzol oxidálószer esetén a fötermék a cisz-diol volt, nem egy esetben csak ezt a vegyületet tudtuk detektálni. Epoxid csak néhány katalizátoron képződött, azon sem jelentős mennyiségben.

19. táblázat: A különböző kompozitok aktivitása a ciklohexén oxidációjában diacetoxi-jódbenzol alkalmazása mellett (víz/aceton (5/95): $10 \mathrm{~cm}^{3}$; ciklohexén: $5 \mathrm{mmol}$; diacetoxi-jódbenzol: 2,5 mmol).

\begin{tabular}{|c|c|c|c|c|c|}
\hline $\begin{array}{l}\text { CaAl-LDH } \\
\text { kompozitok }\end{array}$ & $\begin{array}{c}\text { TOF }(1 / h) / \\
\text { konverzió } \\
(\%)\end{array}$ & $\begin{array}{l}\text { epoxid } \\
(\mathrm{mol} \%)\end{array}$ & $\begin{array}{l}\text { 2-chex-1-ol } \\
(\mathrm{mol} \%)\end{array}$ & $\begin{array}{l}\text { 2-chex-1- } \\
\text { on }(\operatorname{mol} \%)\end{array}$ & $\begin{array}{c}\text { cisz-diol } \\
(\mathrm{mol} \%)\end{array}$ \\
\hline- & $\mathrm{nr} / 19$ & 49 & 28 & 17 & 6 \\
\hline CaAl-LDH & $\mathrm{nr} / 19$ & 50 & 28 & 16 & 6 \\
\hline $\mathrm{Cu}(\mathrm{II})-\mathrm{Tyr}$ & $12 / 41$ & 0 & 0 & 0 & 100 \\
\hline $\mathrm{Cu}(\mathrm{II})-\mathrm{Cys}$ & $15 / 35$ & 0 & 8 & 0 & 92 \\
\hline $\mathrm{Cu}(\mathrm{II})-\mathrm{His}$ & $20 / 40$ & 0 & 7 & 0 & 93 \\
\hline $\mathrm{Ni}(\mathrm{II})-\mathrm{Tyr}$ & $44 / 20$ & 0 & 0 & 0 & 100 \\
\hline $\mathrm{Ni}(\mathrm{II})-\mathrm{Cys}$ & $58 / 53$ & 0 & 0 & 0 & 100 \\
\hline $\mathrm{Ni}(\mathrm{II})$-His & $27 / 41$ & 0 & 0 & 0 & 100 \\
\hline $\mathrm{Fe}(\mathrm{III})-\mathrm{Tyr}$ & $43 / 41$ & 17 & 0 & 0 & 83 \\
\hline $\mathrm{Fe}(\mathrm{III})-\mathrm{Cys}$ & $63 / 54$ & 0 & 0 & 0 & 100 \\
\hline $\mathrm{Fe}(\mathrm{III})$-His & $98 / 33$ & 13 & 0 & 0 & 87 \\
\hline
\end{tabular}

$\mathrm{Ni}(\mathrm{II}): 25 \mathrm{mg}$ katalizátor, $25^{\circ} \mathrm{C}, 3$ óra.

$\mathrm{Cu}(\mathrm{II}): 35 \mathrm{mg}$ katalizátor, $25^{\circ} \mathrm{C}, 4$ óra.

Fe(III): 65 mg katalizátor, $50{ }^{\circ} \mathrm{C}, 6$ óra.

$\mathrm{Az}$ is megállapítható, hogy drámai kölünbségek nincsenek a katalizátorok aktivitásában, bármelyik oxidálószert is alkalmaztuk.

A kompozitok recirkulációs sajátságai kiemelkedően jók voltak, vagyis szerkezetük a reakciók során alig változott. A diffraktogramok bizonyítják, hogy megmaradt az LDHszerkezet a 4. felhasználás után is, míg az IR spektrumok megmutatták, hogy a rétegek között található szerves anyag is megmarad a reakciók során (közel) változatlan állapotban. ICP-OES méréseink szerint a fém ionok kimosódása (leaching) is jelentéktelen volt. 

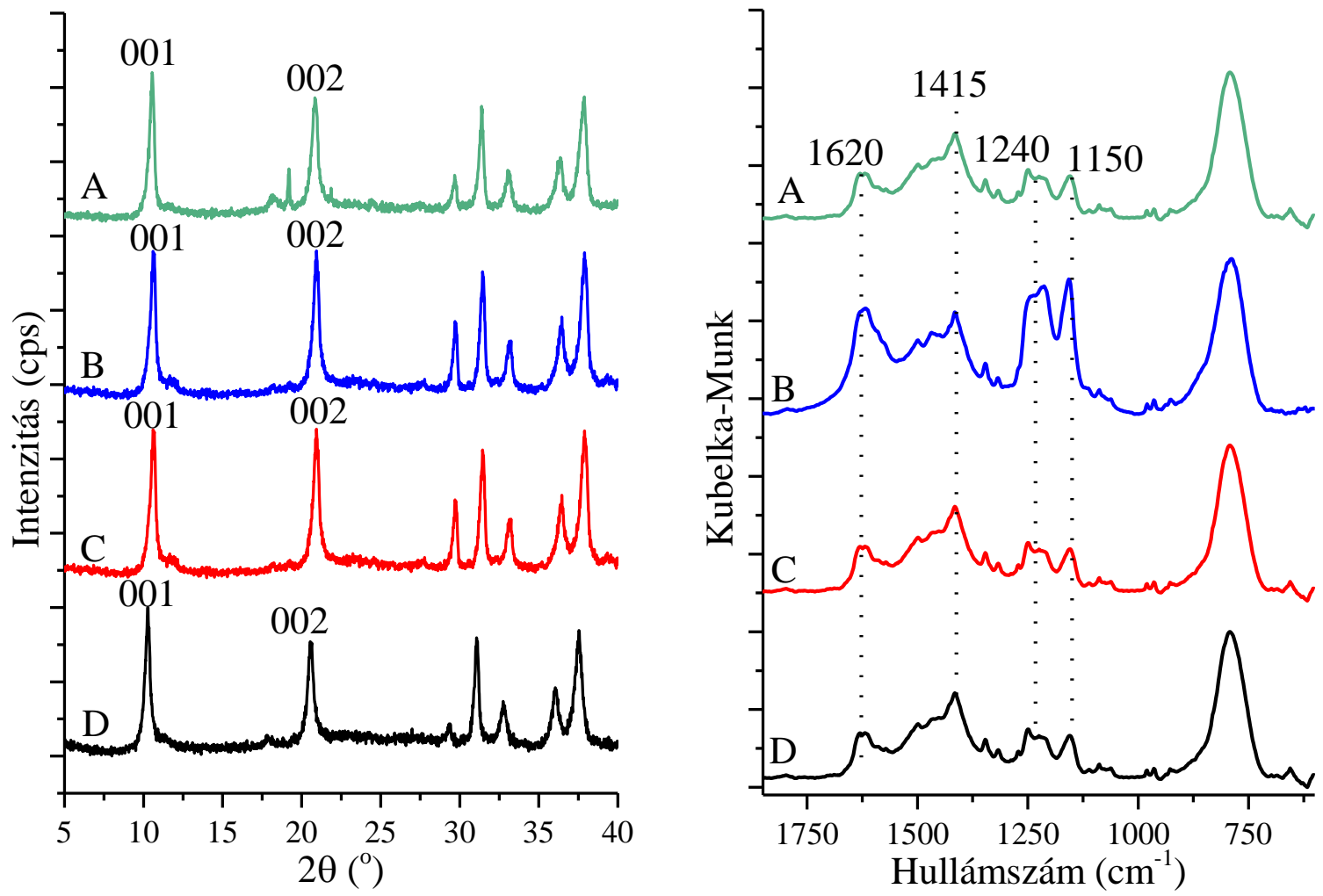

46. ábra: CaAl-Mn(II)-hisztidinát-LDH kompozit röntgen diffraktogramjai (a) és IR spektrumai (b) többszöri felhasználás után a ciklohexén oxidációjában. A: 1. felhasználás után; B: 2. felhasználás után; C: 3. felhasználás után; D: felhasználás előtt (katalizátor: $25 \mathrm{mg}$; aceton: $10 \mathrm{~cm}^{3}$; ciklohexén: $5 \mathrm{mmol}$; perecetsav: $2,5 \mathrm{mmol}$; hömérséklet: $25^{\circ} \mathrm{C}$; reakcióidő: 3 óra).

\section{Az oxidációs reakciók valószínű mechanizmusai}

Indulásként megismételjük a mechanizmuselképzelések szempontjából legfontosabb három megállapítást:

(i) az átmenetifém komplexek jelenlétében jelentősen megnő a konverzió a homogén fázisú, sztöchiometrikus reakció esetén tapasztaltakhoz képest;

(ii) a reakciók mind reakciósebességi, mind szelektivitási szempontból kevéssé érzékenyek a központi ion és a ligandumok anyagi minőségére;

(iii) a perecetsav alkalmazása esetén a főtermék az epoxid, dihidroxi-jódbenzol használatakor a cisz-diol volt.

Az első megállapítás egyértelműen azt jelenti, hogy a rekciók katalizátora az átmenetifém komplex.

A második megállapítás arra utal, hogy a fém ionok szerepe föként az, hogy koordinációs lehetőséget biztosítsanak az oxidálószereknek, amelyek koordinációjukkor feltehetőleg az egyik vízmolekula ligandumot helyettesítik. Az aminosav ligandumok szerepe pedig főként sztérikus: befolyásolják a központi ionok hozzáférhetőségét. 
Bár ezt a lehetőséget ebben a munkában nem használtuk ki, valószínűleg az aminosav ligandumok kiralitása befolyásolná az oxidációs reakció enantioszelektivitását, ha királis lenne a termék. Úgy gondoljuk, hogy a ciklohexén koordinációja perecetsav oxidálószer esetén nem történik meg, ezért áll meg a reakció az epoxidációnál. Ha koordinálódna, akkor a molekula sokkal hosszabb ideig tartózkodna a koordinációs övezetben, és jelentősen nagyobb lenne az esély a gyürüfelnyílásra, ami transz-diol képződéséhez vezetne.

A harmadik megállapítás azt jelenti, hogy a kétféle oxidáns eltérő mechanizmussal müködik. Perecetsav alkalmazása esetén a Jacobsen-Katsuki mechanizmus valószínűsíthető. ${ }^{201,202,203}$ Eszerint a folyamat során kialakuló intermedier komplexből (a perecetsav már koordinálódott) történik meg a peroxid oxigén átadása a kettős kötésre egy koncertikus reakcióval. Diacetoxi-jódbenzol esetén epoxidképzédés vagy egyáltalán nincs, vagy nagyon alárendelt reakció a cisz-diol képződéséhez képest. A transz-diol (ez lenne a gyürünyitási termék) teljes hiánya is ezt igazolja. Ennél az oxidálószernél az történhetett, hogy az oxidálószer a két hidroxilcsoportjának oxigénjein keresztül koordinálódott a központi fém ionhoz (kiszorítva mindkét vízmolekulát a koordinációs szférából). Ezt követően a két oxigénatom transzferje egyszerre történik meg egy a fém iont is tartalmazó gyürüs intermedieren keresztül.

\subsubsection{A kompozitok aktivitása az Ullmann-típusú éterképzésben}

A $\mathrm{Cu}$ (II)- és $\mathrm{Fe}(\mathrm{III})$-tartalmú rendszerek aktív és újrafelhasználható katalizátornak bizonyultak az Ullmann-típusú éterképzési reakcióban (20. táblázat).

20. táblázat: $\mathrm{A} \mathrm{Cu}(\mathrm{II})$ - és $\mathrm{Fe}(\mathrm{III})$-tartalmú kompozitok aktivitása az Ullmann-típusú éterképzésben $\left(5 \mathrm{~cm}^{3}\right.$ toluol [szervetlen bázis alkalmazása esetén $0,5 \mathrm{~cm}^{3}$ víz]; $0,6 \mathrm{mmol}$ jódbenzol; $0,5 \mathrm{mmol}$ fenol; 0,5 mmol bázis; reakcióidő: 24 óra; reakcióhőmérséklet: $\left.95{ }^{\circ} \mathrm{C}\right)$.

\begin{tabular}{cccccc}
\hline $\mathrm{CaAl}-\mathrm{LDH}$ & \multicolumn{5}{c}{$\mathrm{TOF}(1 / \mathrm{h}) /$ Konverzió $(\%)$} \\
\cline { 2 - 6 } kompozitok & - & $\mathrm{Na}_{2} \mathrm{CO}_{3}$ & $\mathrm{~K}_{2} \mathrm{CO}_{3}$ & piridin & Piperidin \\
\hline $\mathrm{CaAl}-\mathrm{LDH}$ & - & 0 & 3 & 0 & 0 \\
\hline $\mathrm{Cu}(\mathrm{II})-\mathrm{Tyr}$ & $11 / 29$ & $7 / 19$ & $17,5 / 45$ & - & $12 / 31$ \\
$\mathrm{Cu}(\mathrm{II})-\mathrm{Cys}$ & $28 / 50$ & $13 / 23$ & $36 / 65$ & - & $31 / 54$ \\
$\mathrm{Cu}(\mathrm{II})-\mathrm{His}$ & $29 / 41$ & $20 / 30$ & $49 / 73$ & - & $34 / 50$ \\
\hline $\mathrm{Fe}(\mathrm{III})-\mathrm{Tyr}$ & $74 / 35$ & $40 / 19$ & $42 / 20$ & $111 / 53$ & $94 / 45$ \\
$\mathrm{Fe}(\mathrm{III})-\mathrm{Cys}$ & $68 / 29$ & $49 / 21$ & $56 / 24$ & $94 / 40$ & $84 / 36$ \\
$\mathrm{Fe}(\mathrm{III})-H i s$ & $160 / 27$ & $106 / 18$ & $148 / 25$ & $260 / 44$ & $242 / 41$ \\
\hline
\end{tabular}

Az LDH kompozitok önmagukban is mutattak aktivitást, de a megfelelő bázis hozzáadásával növelni lehetett a konverziókat. A Cu(II)-tartalmú rendszerek esetén a 
$\mathrm{K}_{2} \mathrm{CO}_{3}$ bizonyult a leghatékonyabb bázisnak, a Fe(III)-tartalmú minták esetén ez a piridin volt. Fontos megjegyeznünk, hogy a reakció oldószere a DMSO-hoz illetve benzolhoz (amelyek általánosan alkalmazott oldószerek ebben a reakcióban) képest környezetbarát toluol volt, és a reakció hőmérséklete sem volt túl magas $\left(95^{\circ} \mathrm{C}\right)$.

A minták recirkulációs sajátságai kiválóak voltak (21. táblázat). Ugyanakkor a tirozináttartalmú minták esetében körülbelül $5 \%$-os kimosódást (leaching) tapasztaltunk minden egyes lépés után az ICP mérések alapján.

21. táblázat: $\mathrm{A} \mathrm{Cu}(\mathrm{II})-$, és $\mathrm{Fe}(\mathrm{III})$-tartalmú kompozitok újrafelhasználhatósága az Ullmann-típusú éterképzésben.

\begin{tabular}{ccccc}
\hline CaAl-LDH & \multicolumn{4}{c}{ Konverzió (\%) } \\
\cline { 2 - 5 } kompozitok & 1. felh. & 2. felh. & 3. felh. & 4. felh. \\
\hline $\mathrm{Fe}(\mathrm{III})-\mathrm{Tyr}$ & $111 / 53$ & $82 / 39$ & $82,5 / 40$ & $73 / 35$ \\
$\mathrm{Fe}(\mathrm{III})-\mathrm{Cys}$ & $94 / 40$ & $101,5 / 43$ & $101,5 / 43$ & $101,5 / 43$ \\
$\mathrm{Fe}(\mathrm{III})-\mathrm{His}$ & $260 / 44$ & $183 / 31$ & $165 / 28$ & $171 / 29$ \\
\hline $\mathrm{Cu}$ (II)-Tyr & $17,5 / 45$ & $14 / 35$ & $12 / 31$ & $11 / 29$ \\
$\mathrm{Cu}(\mathrm{II})-\mathrm{Cys}$ & $36 / 65$ & $33 / 59$ & $31,5 / 57$ & $31 / 56$ \\
$\mathrm{Cu}(\mathrm{II})-\mathrm{His}$ & $49 / 73$ & $43 / 64$ & $40 / 60$ & $39,5 / 59$ \\
\hline
\end{tabular}

Korábban alkalmaztak Fe(III)-kloridot katalizátorként, és magasabb, 85\%-os konverziót értek el, de sokkal erélyesebb körülmények között, a kevéssé környezetbarát DMF oldószerben és magas, $180{ }^{\circ} \mathrm{C}$ hőmérsékleten. ${ }^{122}$ Toluolban ez a katalizátor csupán 17\%-os konverziót eredményezett.

$\mathrm{Cu}(\mathrm{I})$-, illetve $\mathrm{Cu}(\mathrm{II})$-tartalmú szilícium-dioxid-hordozós katalizátorokon elérhető volt 92\%-os konverzió is, de megintcsak magas hőmérsékleten és DMF alkalmazása mellett. ${ }^{121}$ Ezek a katalizátorok toluolban egyáltalán nem müködtek. 


\section{6. Összefoglalás}

Az elmúlt néhány évtizedben LDH-kat sokféle célra használták. Az egyik ilyen terület a hordozóként történő felhasználás. Ennek során biológiai hatású molekulák anionjait, szerves kémiai reakciók érzékeny szintonjait, katalitikus hatású szerves molekulák anionjait és esetenként átmenetifém komplexek anionjait is sikerrel építették be sokfajta LDH rétegei közé különféle módszerekkel. Ez utóbbi munkák ritkák és aminosavak még sosem szerepeltek ligandumként. Ezért a disszertációhoz vezető kísérleti munka során a cél $\mathrm{Mn}(\mathrm{II}), \mathrm{Ni}(\mathrm{II}), \mathrm{Cu}(\mathrm{II}), \mathrm{Fe}(\mathrm{III})$ átmenetifém ionokat tartalmazó aminosav komplexek beépítése volt a CaAl-LDH rétegei közé. A beépítés sikerességének, a komplexek szerkezetének és katalitikus aktivitásának jellemzése is a munka része volt. Az interkalációt többféle módon megkíséreltük, és végül a direkt anioncsere módszerének a beépítendő komplex tulajdonságaitól függő variációi bizonyultak megvalósíthatónak.

A direkt anioncserének egyik megvalósítása szerint ( $A$ módszer) az első lépésben az aminosavakat anionos formájukban interkaláltuk. A rétegtávolság változásának vizsgálatára röntgen diffraktometriát, a szerves anyag beépülésének nyomon követésére IR spektroszkópiát alkalmaztunk. Második lépésként a fém ion lúgos vagy semleges vizes etanolos oldatával kezeltük az aminosav anionokkal interkalált LDH-t. A megfelelö paraméterek megkeresése után ( $\mathrm{pH}$, aminosav:fém ion arány) néhány esetben (Mn(II)-His, $\mathrm{Cu}(\mathrm{II})-\mathrm{Cys}, \mathrm{Ni}(\mathrm{II})-\mathrm{Cys}$ és $\mathrm{Fe}(\mathrm{III})-\mathrm{Cys})$ sikerült a komplexek kiépítése döntően a rétegek között.

A $B$ módszer esetén oldatban hoztuk létre a komplexet, és ezt igyekeztünk beépíteni a rétegek közé anionos formában. Fontos szintézisparaméternek bizonyult a pH-n és az aminosav:fém ion arányon kívül a szintézisek során alkalmazott oldószerelegy is. Ez a módszer hatékonyabbnak bizonyult, mint az előző. Így sikerült CaAl-LDH-ba interkalálnunk anionos $\mathrm{Mn}(\mathrm{II})-\mathrm{Tyr}$, a $\mathrm{Mn}(\mathrm{II})-\mathrm{Cys}$, a $\mathrm{Cu}(\mathrm{II})-\mathrm{His}$, a $\mathrm{Cu}(\mathrm{II})-\mathrm{Tyr}$, a Fe(III)-His, a Fe(III)-Tyr, a Ni(II)-His és a Ni(II)-Tyr komplexeket.

Az interkalált rendszereket sokféle módszerrel jellemeztük. Ezek közül az LDH gazda szerkezetének és morfológiájának leírására használtunk XRD, SEM, TEM, IR, XPS és TEM technikákat. Az interkalált/kiépített komplex kvantitatív és szerkezeti jellemzésére igénybe vettünk TEM, SEM-EDX, ICP-OES, XAS, UV-Vis, közép és távoli IR, Raman, ESR és XPS méréseket, valamint molekulamodellezést is. 
Kiderült, hogy mindegyik kialakított vagy beépített komplex oktaéderes szerkezetü, a koordinációs szférában van két darab kétfogú ligandumként viselkedő aminosav és két darab vízmolekula. A főbb koordinálódó atomok az imidazol, illetve az aminocsoport nitrogénje, a tiolát kénatomja, illetve a fenolát oxigénje, néha a karboxilát oxigén és a vízmolekulák oxigénje. A kompozitokban az LDH réteges szerkezete megmaradt, a rétegetávolság általában változott, az esetek többségében növekedett.

A sikeresen elöállított minták mindegyike katalizátorként viselkedett, és enyhe körülmények között jó konverzióval katalizálta a ciklohexén oxidációs átalakulásait perecetsav, illetve az in situ képződő dihidroxi-jódbenzol oxidálószer alkalmazása mellett. Perecetsav használatakor epoxidszelektivitást, dihidroxi-jódbenzol esetén döntően a ciszdiol képződést figyeltünk meg. A fötermékek különbözősége az átalakulási mechanizmusok nagymérvü eltérésére utal.

A $\mathrm{Cu}(\mathrm{II})$-, valamint $\mathrm{Fe}(\mathrm{III})$-tartalmú kompozitok aktívnak és újrafelhasználhatónak bizonyultak az Ullmann-típusú éterképzésben, különösen bizonyos hozzáadott bázisok jelenlétében. 


\section{Irodalomjegyzék}

${ }^{1}$ W. Feitknecht, G. Fischer, Helv. Chim. Acta 18 (1935) 555-569.

${ }^{2}$ M. Catti, G. Ferraris, S. Hull, A. Pavese, Phys. Chem. Miner. 22 (1995) 200-206.

${ }^{3}$ H.F.W. Taylor, Mineral. Mag. 39 (1973) 377-389.

${ }^{4}$ I. Rousselot, C. T.-Guého, F. Leroux, P. Léone, P. Palvadeau, J.-P. Besse, J. Solid State Chem. 167 (2002) 137-144.

${ }^{5}$ V. Rives, in: Layered Double Hydroxides: Present and Future, Nova Science Publisher, New York (2001).

${ }^{6}$ R.C. Peterson, R.J. Hill, G.V. Gibbs, Can. Mineral. 17 (1979) 703-711.

${ }^{7}$ M. Szabados, Cs. Bús, M. Ádok-Sipiczki, Z. Kónya, Á. Kukovecz, P. Sipos, Pálinkó, Particuology 27 (2016) 29-33.

${ }^{8}$ G.D. Evans, R.C.T. Slade, Struct. Bond. 119 (2006) 1-87.

${ }^{9}$ D. Srankó, M. Sipiczki, É.G. Bajnóczi, M. Darányi, Á. Kukovecz, Z. Kónya, S.E. Canton, K. Norén, P. Sipos, I. Pálinkó, J. Mol. Struct. 993 (2011) 62-66.

${ }^{10}$ H. Curtius, K. Ufer, K. Dardenne, Radiochim. Acta 97 (2009) 423-428.

${ }^{11}$ Zs. Ferencz, M. Szabados, M. Ádok-Sipiczki, Á. Kukovecz, Z. Kónya, P. Sipos, I. Pálinkó, J. Mater. Sci. 49 (2014) 8478-8486.

${ }^{12}$ A.I. Khan, D. O’Hare, J. Mater. Chem. 12 (2002) 3191-3198.

${ }^{13} \mathrm{G}$. Alberti, U. Costantino: Solid state supramolecular chemistry: Two- and three-dimensional inorganic networks, In: Comprehensive Supramolecular Chemistry, vol.7, Pergamon and Elsevier Science, Oxford (1996).

${ }^{14}$ S. Miyata, Clays Clay Miner. 28 (1980) 50-56.

${ }^{15}$ F. Leroux, J.-P. Besse, Chem. Mater. 13 (2001) 3507-3515.

${ }^{16}$ S. Miyata, Clays Clay Miner. 31 (1983) 305-311.

${ }^{17}$ F. Bruna, R. Celis, M. Real, J. Cornejo, J. Hazard. Mater. 225 (2012) 74-80.

${ }^{18}$ V. Ambrogi, G. Fardella, G. Grandolini, L. Perioli, Int. J. Pharm. 220 (2001) 23-32.

${ }^{19}$ M. Sipiczki, A.A. Ádám, T. Anitics, Z. Csendes, G. Peintler, Á. Kukovecz, Z. Kónya, P. Sipos, I. Pálinkó, Catal. Today 241 (2015) 231-236.

${ }^{20}$ D. Meloni, R. Monaci, V. Solinas, A. Auroux, E. Dumitriu, Appl. Catal. A 350 (2008) 86-95.

${ }^{21}$ Z.P. Xu, J. Zhang, M.O. Adebajo, H. Zhang, C. Zhou, Appl. Clay Sci. 53 (2011) 139-150.

${ }^{22}$ F. Cavani, F. Trifiró, A. Vaccari, Catal. Today 11 (1991) 173-301.

${ }^{23}$ C. Ruby, R. Aïssa, A. Géhin, J. Cortot, M. Abdelmoula, J.-M.R. Génin, C. R. Geosci. 338 (2006) 420-432.

${ }^{24}$ J.J. Bravo-Suárez, E.A. Páez-Mozo, S.T. Oyama, Quim. Nova 27 (2004) 601-614.

${ }^{25}$ M. Adachi-Pagano, C. Forano, J.P. Besse, J. Mater. Chem. 13 (2003) 1988-1993.

${ }^{26}$ M. Ogawa, H. Kaiho, Langmuir 18 (2002) 4240-4242.

${ }^{27}$ V. R. Khusnutdinov, V. P. Isupov, Chemistryy for Sustainable Development 15 (2007) 367-372.

${ }^{28}$ W. Tongamp, Q. Zhang and F. Saito, J. Mater. Sci. 42 (2007) 9210-9215. 
${ }^{29}$ D. Braga, S. L. Giaffreda, F. Grepioni, A. Pettersen, L. Maini, M. Curzi and M. Polito, Dalton Trans. (2006) 1249-1263.

${ }^{30}$ A. N. Ay, B. Zümreoglu-Karan and L. Mafra, Z. Anorg. Allg. Chem. 635 (2009) 1470-1475.

${ }^{31}$ F. Zhang, N. Du, H. Li, J. Liu, W. Hou, Solid State Sci. 32 (2014) 41-47.

${ }^{32}$ X. Ni, K. Kuang, X. Jin, X. Xiao, G. Liao, Solid State Sci. 12 (2010) 546-551.

${ }^{33}$ N. Morel-Desrosiers, J. Pisson, Y. Israeli, C. Taviot-Guého, J.P. Besse, J.P. Morel, J. Mater. Chem. 13 (2003) 2582-2585.

${ }^{34}$ Y. Israeli, C. Taviot-Guého, J.P. Besse, J.P. Morel, N. Morel-Desrosiers, J. Chem. Soc., Dalton Trans. (2000) 791-796.

${ }^{35}$ S. Xing, D.Q. Li, L.L. Ren, D.G. Evans, X. Duan, Huaxue Xuebao 61 (2003) 267-272.

${ }^{36}$ S.P. Newman, W. Jones, New J. Chem. (1998) 105-115.

${ }^{37}$ K.K. Ravi, S.W. Marc, E.A. James, Chem. Mater. 9 (1997) 417-419.

${ }^{38}$ F. Malherbe, C. Forano, J. P. Besse, Microporous Mater. 10 (1997) 67-84.

${ }^{39}$ E. Kanezaki, K. Maeda, Nippon Kagaku Kaishi 3 (2002) 393-397.

${ }^{40}$ T. Hibino, A. Tsunashima, Chem. Mater. 10 (1998) 4055-4061.

${ }^{41}$ K. Ladewig, M. Niebert, Z. Ping Xu, P. P. Gray, G. Q. Lu, App. Clay Sci. 48 (2010) 280-289.

${ }^{42}$ S. O'Leary, D. O’Hare, G. Seeley, Chem. Commun. (2002) 1506-1507.

${ }^{43}$ N.T. Whilton, P.J. Vickers, S. Mann, J. Mater. Chem. 7 (1997) 1623-1629.

${ }^{44}$ F. Wypych, G.A. Bubniak, M. Halma, S. Nakagaki, J. Coll. Int. Sci. 264 (2003) 203-207.

${ }^{45}$ R. Prins, A. Wang, X. Li, In: Intoduction to Heterogeneous Catalysis, World Scientific Publishing Ltd., New York (2016).

${ }^{46}$ B.M. Weckhuysen, J. Am. Chem. Soc. 128 (2006) 3208-3217.

${ }^{47}$ C.-H. Lee, T.-S. Lin, C.-Y. Mou, Nano Today 4 (2009) 165-179.

${ }^{48}$ A. Valente, A. M. Botelho do Rego, M.J. Reis, I.F. Silva, A.M. Ramos, J. Vital, Appl. Catal. A 207 (2001) 221-228.

${ }^{49}$ K. Kenada, M. Higuchi, T. Imanaka, J. Mol. Catal. 63 (1990), L33-L52.

${ }^{50}$ L. Djakovitch, H. Heise, K. Köhler, J. Organomet. Chem. 584 (1999) 16-26.

${ }^{51}$ R.S. Varma, K.P. Naicker, P.J. Liesen, Tetrahedron Lett. 40 (1999) 2075-2076.

${ }^{52}$ B.M. Choudary, S. Madhi, N.S.Chowdari, M.L. Kantam, B. Sreedhar, J. Am. Chem. Soc. 124 (2002) 14127-14136.

${ }^{53}$ B. Yuan, X. He, Y. Chen, K. Wang, Macromol. Chem. Phys. 212 (2011) 2378-2388.

${ }^{54}$ C.L. LeBlond, A.T. Andrews, Y. Sun, A.R. Sowa Jr., Org. Lett. 10 (2001) 1555-1557.

${ }^{55}$ H. Bulut, L. Artok, S. Yilmaz, Tetrahedron Lett. 44 (2003) 289-291.

${ }^{56}$ S. Paul, J.H. Clark, Green Chem. 5 (2003) 635-638.

${ }^{57}$ I.U. Castro, F. Stüber, A. Fabregat, J. Font, A. Fortuny, C. Bengoa, J. Hazard. Mater. 163 (2009) 809-815.

${ }^{58}$ S.T. Castaman, S. Nakagaki, R.R. Ribeiroa, K.J. Ciuffi, S.M. Drechsel, J. Mol. Catal. A 300 (2009) 89-97.

${ }^{59}$ F. Farzaneh, M. Majidian, M. Ghandi, J. Mol. Catal. A 148 (1999) 227-233.

${ }^{60}$ F. Farzaneh, S. Sadeghi, L. Turkian, M. Ghandi, J. Mol. Catal. A 132 (1998) 255-261. 
${ }^{61}$ J.G. Mesu, T. Visser, A.M. Beale, F. Soulimani, B.M. Weckhuysen, Chem. Eur. J. 12 (2006) 7167-7177.

${ }^{62}$ N.H. Gutmann, L. Spiccia, T.W. Turney, J. Mater. Chem. 10 (2000) 1219-1224.

${ }^{63}$ M. Halma, K.A.D. de Freitas Castro, C. Taviot-Gueho, V. Prévot, C. Forano, F. Wypych, S. Nakagaki, J. Catal. 257 (2008) 233-243.

${ }^{64}$ T.C.O. MacLeod, M.N. Kopylovich, M.F.C. Guedes da Silva, K.T. Mahmudov, A.J.L. Pombeiro, Appl. Catal. A 439-440 (2012) 15-23.

${ }^{65}$ V.B. Valodkar, G.L. Tembe, M. Ravindranathan, R.N. Ram, H.S. Rama, J. Mol. Catal. A 208 (2004) 21-32.

${ }^{66}$ S.M. Islam, M. Mobarok, P. Mondal, A.S. Roy, N. Salam, D. Hossain, S. Mondal, Trans. Met. Chem. 37 (2012) 97-107.

${ }^{67}$ J.M. Thomas, R. Raja, Acc. Chem. Res. 41 (2008) 708-720.

${ }^{68}$ C. Song, L. Sheng, X. Zhang, Appl. Microbiol. Biotechnol. 1 (2012) 123-124.

${ }^{69}$ C. Vartzouma, E. Evaggellou, Y. Sanakis, N. Hadjiliadis, M. Louloudi, J. Mol. Catal. A. 263 (2007) 77-85.

${ }^{70}$ I. Szilágyi, O. Berkesi, M. Sipiczki, L. Korecz, A. Rockenbauer, I. Pálinkó, Catal. Lett. 127 (2009) 239-247.

${ }^{71}$ Y. Zhang, J. Zhao, L. He, D. Zhao, S. Zhang, Mic. Mes. Mater. 94 (2006) 159-165.

${ }^{72}$ J. Gao, Y. Chen, B. Han, Z. Feng, C. Li, N. Zhou, Z. Gao, J. Mol. Catal. A 210 (2004) 197-204.

${ }^{73}$ S. Samantaray, K. Parida, Catal. Commun. 6 (2005) 578-581.

${ }^{74}$ J. Jiang , K. Ma, Y. Zheng, S. Cai, R. Li, J. Ma, Appl. Clay Sci. 45 (2009) 117-122.

${ }^{75}$ R. Noyori, M. Aoki, K. Sato, Chem. Commun. (2003) 1977-1986.

${ }^{76}$ T. Punniyamurthy, L. Rout, Coord. Chem. Rev. 252 (2008) 134-135.

${ }^{77}$ H. Shi, Z. Zhang, Y. Wang, J. Mol. Catal. A 238 (2005) 13-25.

${ }^{78}$ S.M. Islam, P. Mondal, S. Mukherjee, A.S. Roy, A. Bhaumik, Polym. Adv. Technol. 22 (2011) 933-942.

${ }^{79}$ B.M. Weckhuysen, A.A. Verberckmoes, I.P. Vannijvel, J.A. Pelgrims, P.L. Buskens, P.A. Jacobs, R.A. Schoonheydt, Angew. Chem. Int. Ed. Engl. 34 (1995) 2652-2654.

${ }^{80}$ I. Kuzniarska-Biernacka, K. Biernacki, A.L. Magalhaes, A.M. Fonseca, I.C. Neves, J. Catal. 278 (2011) 102-110.

${ }^{81}$ G. Olason, D.C. Sherrington, React. Funct. Polym. 42 (1999) 163-172.

${ }^{82}$ H. Sohrabi, M. Esmeeli, F. Farzaneh, M. Ghandi, J. Incl. Phenom. Macromol. 54 (2006) 23-28.

${ }^{83}$ S. Khare, R. Chokhare, J. Mol. Catal. A 344 (2011) 83-92.

${ }^{84}$ A. Stamatis, P. Doutsi, K.C. Christoforidis, Y. Deligiannakis, M. Louloudi, J. Mol. Catal. A 297 (2009) 44-53.

${ }^{85}$ J. Tang, Y. Zu, W. Hou, L. Wang, J. Wang, M. Jia, W. Zhang, W.R. Thiel, J. Mol. Catal. A 355 (2012) 201-209.

${ }^{86}$ T.J. Terry, T.D.P. Stack, J. Am. Chem. Soc. 130 (2008) 4945-4953.

${ }^{87}$ Z. Csendes, G. Varga, N. V. Nagy, E. G. Bajnoczi, M. Sipiczki, S. Carlson, S. E. Canton, A. Metzinger, G. Galbacs, P. Sipos, I. Palinko, Catal. Today 241 (2015) 264-269. 
${ }^{88}$ Z. Csendes, G. Varga, H. Schmehl, Z. Timár, S. Carlson, S. E. Canton, É. G. Bajnóczi, D. Sebok, I. Dékány, Gábor Elek, P. Sipos, I. Pálinkó, J. Mol. Catal. A 395 (2014) 93-99.

${ }^{89}$ G. Varga, Z. Timar, H. Schmehl, Z. Csendes, É. G. Bajnoczi, S. Carlson, P. Sipos, I. Palinko, React. Kinet. Mech. Cat. 115 (2015) 33-43.

${ }^{90}$ G. Varga, Z. Csendes, E. G. Bajnoczi, S. Carlson, P. Sipos, I. Palinko, Res. Chem. Intermed. 41 (2015) 9155-9169.

${ }^{91}$ A. Kotz, K. Richter, J. prakt. Chem. 11 (1925) 373-400.

${ }^{92}$ S. Suzuki, US3956318 A, 1976.

${ }^{93}$ S. Murata, M. Suzuki, R. Noyori, J. Am. Chem. Soc. 101 (1979) 2738-2739.

${ }^{94}$ R.A. Johnson, K.B. Sharpless, In: Catalytic Asymmetric Synthesis, VCH, New York (1993).

${ }^{95}$ A.H. Hoveyda, D. A. Evans, G. C. Fu, Chem. Rev. 93 (1993) 1307-1370.

${ }^{96}$ Columbia-Southern, GB-P 837 464, 1957.

${ }^{97}$ W.M. Weigert, A. Kleemann, G. Schreyer, Chem. Ztg. 99 (1975) 19-25.

${ }^{98}$ H.B. Henbest, R.A.L. Wilson, J. Chem. Soc. (1957) 1958-1965.

${ }^{99}$ C. Denis, K. Misbahi, A. Kerbal, V. Ferrièresa, D. Plusquellec, Chem. Commun. (2001) 2460246.

${ }^{100}$ T. Katsuki, K.B. Sharpless, J. Am. Chem. Soc. 102 (1980) 5974-5976.

${ }^{101}$ W. Adam, P.L. Alsters, R. Neumann, C.R. Saha-Moller, D. Seebach, A.K. Beck, R. Zhang, J. Org. Chem. 68 (2003), 8222-8231.

${ }^{102}$ R. Neumann, M. Gara, J. Am. Chem. Soc. 116 (1994) 5509-5510.

${ }^{103}$ R. Neumann, A.M. Khenkin, J. Mol. Catal. A 114 (1996) 169-180.

${ }^{104}$ W. Adam,V.R. Stegmann, C.R. Saha-Moller, J. Am. Chem. Soc. 121 (1999) 1879-1882.

${ }^{105}$ C. Pereira, K. Biernacki, S.L.H. Rebeloa, A.L. Magalhãesa, A.P. Carvalhob, J. Piresb, C. Freirea, J. Mol. Catal. A 312 (2009) 53-64.

${ }^{106}$ P. Liu, C. Wang, C. Li, J. Catal. 262 (2009) 159-168.

${ }^{107}$ F. Ullmann, P. Sponagel, Chem. Ber. 38 (1905) 2211-2212.

${ }^{108}$ K.C. Nicolaou, C.N.C. Boddy, S. BrGse, N. Winssinger, Angew. Chem. 111 (1999) 2230-2287.

${ }^{109}$ J. Zhu, Synlett (1997) 133-144.

${ }^{110}$ J. Lindley, Tetrahedron 40 (1984) 1433-1456.

${ }^{111}$ A., Aranyos, D.W. Old, A. Kiyomori, J.P. Wolfe, J.P. Sadighi, S.L. Buchwald, J. Am. Chem.Soc. 121(18) (1999) 4369-4378.

${ }^{112}$ R.F. Pellón Comdom, R. Carrasco, V. Milián, L. Rodés, Synth. Commun. 25 (1995) 1077-1083.

${ }^{113}$ T.D. Tuong, M. Hida, Bull. Chem. Soc. Jpn 44 (1971) 765-771.

${ }^{114}$ R.F. Pellón Comdom, M.L. Docampo Palacios, Synth. Commun. 33 (2003) 921-926.

${ }^{115}$ J. F. Marcoux, S. Doye, S. L. Buchwald, J. Am. Chem. Soc. 119 (1997) 10539-10540.

${ }^{116}$ S.V. Ley, A.W. Thomas, Angew. Chem. Int. Ed. 115 (2003) 5558-5607.

${ }^{117}$ D.L. Boger, S.M. Sakya, D. Yohannes, J. Org. Chem. 56 (1991) 4204-4207.

${ }^{118}$ M. Bois-Choussy, P. Cristau, J. Zhu, Angew. Chem. Int. Ed. 115 (2003) 4370-4373.

${ }^{119}$ J.W.W. Chang, S. Chee, S. Maka, P. Buranaprasertsuk, W. Chavasiri, P.W.H. Chan, Tetrahedron Lett. 49 (2008) 2018-2022. 
${ }^{120}$ S.U. Son, I.K. Park, J. Park, T. Hyeon, Chem. Commun. (2004) 778-779.

${ }^{121}$ T. Miao, L. Wang, Tetrahedron Lett. 48 (2007) 95-99.

${ }^{122}$ O. Bistri, A. Correa, C. Bolm, Angew. Chem. Int. Ed. 47 (2008) 586-588.

${ }^{123}$ V. Rives, M.A. Ulibarri, Coord. Chem. Rev. 181 (1999) 61-120.

${ }^{124}$ L. Gaillon, F. Bedioui, J. Devynck, P. Battioni, J. Electroanal. Chem. 347 (1993) 435-442.

${ }^{125}$ E. Lopez-Salinas, P. Salas Castillo, Y. Ono, Mater. Res. Soc. Symp. Proc. 371 (1995) 163-167.

${ }^{126}$ J. Guo, Q.Z. Jiao, J.P. Shen, D.Z. Jiang, G.H. Yang, E.Z. Min, Catal. Lett. 40 (1996) 43-45.

${ }^{127}$ L. Barloy, J.P. Lallier, P. Battioni, D. Mansuy, Y. Piffard, M. Tournous, J.B. Valim, W. Jones, New J. Chem. 16 (1992) 71.

${ }^{128}$ S. Bhattacharjee, J.A. Anderson, Chem. Commun. (2004) 554-555.

${ }^{129}$ E. Coronado, J.R. Galán-Mascarós, C. Martí-Gastaldo, A. Ribera, Chem. Mater. 18 (2006) 6112-6114.

${ }^{130}$ S. Bhattacharjee, J.A. Anderson, Catal. Lett. 95 (2004) 119-125.

${ }^{131}$ S. Bhattacharjee, T.J. Dines, J.A. Anderson, J. Catal. 225 (2004) 398-407.

${ }^{132}$ S. Bhattacharjee, J.A. Anderson, Adv. Synth. Catal. 348 (2006) 151-158.

${ }^{133}$ S. Bhattacharjee, T.J. Dines, J.A. Anderson, J. Phys. Chem. C 112 (2008) 14124-14130.

${ }^{134}$ L. Dai, J. Zhang, X. Wang, Yingqi Chen, RSC Adv. 3 (2013) 19885-19888.

${ }^{135}$ K.A. Carrado, J.E. Forman, R.E. Botto, R.E. Winans, Chem. Mater. 5 (1993) 472-478.

${ }^{136}$ B. Monteiro, S. Gago, S.S. Balula, A.A. Valente, I.S. Gonçalves, M. Pillinger, J. Mol. Catal. A 312 (2009) 23-30.

${ }^{137}$ M. Z. Wang, Y. Li, J. J. Ji, G. L. Huang, X. Zhang, S. H. Li, X.J. Yang, Chin. Chem. Lett. 24 (2013) 593-596.

${ }^{138}$ D.L.A de Faria, V.R.L. Constantino, K.J. Baldwin, D.N. Batchelder, T.J. Pinnavaia, M. Chibwe, J. Raman Spectr. 29 (1998) 103-108.

${ }^{139}$ E. Lopez-Salinas, Y. Ono, Microporous Mater. 1 (1993) 33-42.

${ }^{140}$ A.B.P. Lever, E. Montovani, B.S. Ramaswany, Can. J. Chem. 49 (1971) 1957-1964.

${ }^{141}$ E. Lopez-Salinas, N. Tomita, T. Matsui, E. Suzuki, Y. Ono, J. Mol. Catal. 81 (1993) 397-405.

${ }^{142}$ E. Lopez-Salinas, Y. Ono, E. Suzuki, Mater. Res. Symp. Proc. 368 (1995) 363-368.

${ }^{143}$ K. Okada, F. Matsushita, S. Hayashi, Clay Min. 32 (1997) 299-305.

${ }^{144}$ A.V. Lukashin, A. A. Vertegel, A. A. Eliseev, M. P. Nikiforov, P. Gornert, Y. D. Tretyakov, J. Nanoparticle Res. 5 (2003) 455-464.

${ }^{145}$ K.A. Tarasov, V.A. Isupov, M.M. Yulikov, A.E. Yermakov, D.O'Hare, Solid State Phenomena 90-91 (2003) 527-534.

${ }^{146} \mathrm{G}$. Wu, L. Wang, L. Yang, J. Yang, Eur. J. Inorg. Chem. (2007) 799-808.

${ }^{147}$ C. Gérardin, D. Kostadinova, N. Sanson, B. Coq, D. Tichit, Chem. Mater. 17 (2005) 6473-6478.

${ }^{148}$ L.Y. Wang, G.Q. Wu, D.G. Evans, Mater. Chem. Phys. 104 (2007) 133-140.

${ }^{149}$ S. Miyata, T. Hirose, Clays Clay Min. 26 (1978) 441-447.

${ }^{150}$ P.S. Braterman, C. Tan, J. Zhao, Mater. Res. Bull. 29 (1994) 1217-1221.

${ }^{151}$ S. Kikkawa, M. Koizumi, Mater. Res. Bull. 17 (1982) 191-198.

${ }^{152}$ J.D. Wang, G. Serrette, Y. Tian, A. Clearfield, Appl. Clay Sci. 10 (1995) 103-115. 
${ }^{153}$ S. Idemura, E. Suzuki, Y. Ono, Clays Clay Min. 37 (1989) 553-557.

${ }^{154}$ M.J. Holgado, V. Rives, M.S. San Roman, P. Malet, Solid State Ionics 92 (1996) 273-283.

${ }^{155}$ F.A.P. Cavalcanti, A. Schutz, P. Biloen, Preparation of Catalysts IV, Elsevier, Amsterdam (1987).

${ }^{156}$ T. Challier, R.C.T. Slade, J. Mater. Chem. 4 (1994) 367-371.

${ }^{157}$ B.R. Shaw, Y. Deng, F.E. Strillacci, K.A. Carrado, M.G. Fessehaie, J. Electrochem. Soc. 137 (1990) 3136-3143.

${ }^{158}$ J. Qiu, G. Villemure, J. Electroanal. Chem. 395 (1995) 159-166.

${ }^{159}$ P.K. Dutta, M. Puri, J. Phys. Chem. 93 (1989) 376-381.

${ }^{160}$ M. Halma, F. Wypych, S.M. Drechsel, S. Nakagaki, J. Porphyrins Phthalocyanines 6 (2002) 502-513.

${ }^{161}$ M. Halma, K. A. D. de Freitas Castro, C. Taviot-Gueho, V. Prévot, C. Foranoc, F. Wypych, S. Nakagaki, J. Catal. 257 (2008) 233-243.

${ }^{162}$ K.A.D. de Freitas Castro, A. Bail, P. Braga Groszewicz, G.S. Machadoa, W.H. Schreinerc, F. Wypych, S. Nakagaki, Appl. Catal. A 386 (2010) 51-59.

${ }^{163}$ K.A.D. de Freitas Castro, F. Wypych, A. Antonangelo, K.M. Mantovani, A. Bail, G.M. Ucoski, K.J. Ciuffi, T.E. Cintra, S. Nakagaki, J. Colloid Interface Sci. 478 (2016) 374-383.

${ }^{164}$ W.Y. Zhou, P. Tian, F. Sun, M.Y. He, Q. Chen, J. Catal. 335 (2016) 105-116.

${ }^{165}$ M. Halma, K. A. D. de Freitas Castro, V. Prévot, C. Forano, F. Wypych, S. Nakagaki, J. Mol. Catal. A 310 (2009) 42-50.

${ }^{166}$ S. Nakagaki, M. Halma, A. Bail, G.G. Carbajal Arízaga, F. Wypych, J. Colloid Interface Sci. 281 (2005) 417-423.

${ }^{167}$ F. Wypych, G.A. Bubniak, M. Halma, S. Nakagaki, J. Colloid Interface Sci. 264 (2003) 203207.

${ }^{168}$ X. Wang, G. Wu, X. Liu, C. Zhang, Q. Lin, Catal. Lett. 146 (2016) 620-628.

${ }^{169}$ K.M. Parida, M. Sahoo, S. Singha, J. Mol. Catal. A 329 (2010) 7-12.

${ }^{170}$ L. Maretti, E. Carbonell, M. Alvarob, J.C. Scaianoa, H. Garcia, J. Photochem. Photobiol. A 205 (2009) 19-22.

${ }^{171}$ Z. Huang, P. Wu, X. Zhang, X. Wang, N. Zhu, J. Wu, P. Li, Appl. Clay Sci. 65-66 (2012) 87-94.

${ }^{172} \mathrm{~F}$. Jalilehvand, Structure of Hydrated Ions ond Cyanide Complexes by X-ray absorption Spectroscopy, Doctoral Thesis, Royal Institute of Technology (2000).

${ }^{173}$ G. Bunker, Introduction to XAFS - A Practical Guide to X-ray Absorption Fine Structure Spectroscopy, Cambridge University Press, New York (2010).

${ }^{174}$ G.N. George, I.F. Pickering, 1995, EXAFSPAK - A suite of Computer Programs for Analysis of X-ray Absorption Spectra, Stanford Synchrotron Radiation Laboratory, Stanford, CA, 1995. http://www-ssrl.slac.stanford.edu/exafspak.html.

${ }^{175}$ S.I. Zabinsky, J.J. Rehr, A. Ankudinov, R.C. Albers, M.J. Eller, J. Phys. Rev. B 52 (1995) 29953009.

${ }^{176}$ F.M. Mirabella Jr., Modern Techniques in Applied Molecular Spectroscopy, John Wiley \& Sons Inc., New York (1998).

${ }^{177}$ F.M. Mirabella Jr., Appl. Spectrosc. Rev. 21 (1985) 45-178. 
${ }^{178}$ G. Varga, Z. Csendes, G. Peintler, O. Berkesi, P. Sipos, I. Pálinkó, Spectrochim. Acta Part A 122 (2014) 257-259.

${ }^{179}$ A. Ookubo, K. Ooi, F. Tani, H. Hayashi, Langmuir 10 (1994) 407-411.

${ }^{180}$ Á. Fudala, I. Pálinkó, I. Kiricsi, Inorg. Chem. 38 (1999) 4653-4658.

${ }^{181}$ T. Stimpfling, P. Vialat, H. Hintze-Bruening, P. Keil, V. Shkirskiy, P. Volovitch, K. Ogle, F. Leroux, Eur. J. Inorg. Chem. (2016) 2006-2016.

${ }^{182}$ R.J. Kirkpatrick, A.G. Kalinichev, J. Wang, X. Qiang Hou, J.E. Amonette, Molecular modeling of the vibrational spectra of interlayer and surface species of layered double hydroxides; In: The application of vibrational spectroscopy to clay minerals and layered double hydroxides, CMS Workshop Lectures, Vol. 13, The Clay Mineral Society, Aurora, CO, 239-285 (2005).

${ }^{183}$ C.R. Andrew, H. Yeom, J. Selverstone Valentine, B.G. Karlsson, N. Bonander, G.V. Pouderoyen, G.W. Canters, T.M. Loehr, J. Sanders-Loeh, J. Am. Chem. Soc. 116 (1994) 1148911498.

${ }^{184}$ Z. Luan, J. Xu, L. Kevan, Chem. Mater. 10 (1998) 3699-3706.

${ }^{185}$ P.F. Rapheal, E. Manoj, M.R. Prathapachandra Kurup, Polyhedron 26 (2007) 5088-5094.

${ }^{186}$ C. Duboc, M.N.Collomb, F. Neese, Appl. Magn. Reson. 37 (2010) 229-245.

${ }^{187}$ B.J. Hathaway, G.A.A. Tomlinson, Coord. Chem. Rev. 5 (1970) 1-43.

${ }^{188}$ G.G. Mohamed, M.M. Omar, A.A. Ibrahim, Eur. J. Med. Chem. 44 (2009) 4801-4812.

${ }^{189}$ P.M. Krishna, K.H. Reddy, J.P. Pandey, D. Siddavattam, Transition Met. Chem. 33 (2008) 661668.

${ }^{190}$ K. Várnagy, E. Garribba, D. Sanna, I. Sóvágó, G. Micera, Polyhedron 24 (2005) 799-806.

${ }^{191}$ T. Szabó-Plánka, A. Rockenbauer, L. Korecz, D. Nagy, Polyhedron 19 (2000) 1123-1131.

${ }^{192}$ L.D. Pinto, P.A.L. Puppin, V.M. Behring, O.C. Alves, N.A. Rey, J. Felcman, Inorg. Chim. Acta 386 (2012) 60-67.

${ }^{193}$ J.A. Farrar, A. Formicka, M. Zeppezauer, A.J. Thomson, J. Biochem. 317 (1996) 447-456.

${ }^{194}$ J. Stöhr, Nexafs Spectroscopy, Springer, Berlin (1996).

${ }^{195}$ J.J. Led, D.M. Grant, J. Am. Chem. Soc. 97 (1975) 6962-6970.

${ }^{196}$ H. Gunter, K.E. Schwarzhans, Z. Naturforsch. B Chem. Sci. 31 (1976) 448-454.

${ }^{197}$ T. Kiss, A. Gergely, J. Chem. Soc., Dalton Trans. (1984) 1951-1957.

${ }^{198}$ O. Yamauchi, A. Odani, J. Am. Chem. Soc. 107 (1985) 5938-5945.

${ }^{199}$ J.J. Led, D.M. Grant, J. Am. Chem. Soc. 99 (1977) 5845-5858.

${ }^{200}$ A. Wojciechowska, M. Daszkiewicz, Z. Staszak, A. Trusz-Zdybek, A. Bienko, A. Ozarowski, Inorg. Chem. 50 (2011) 11532-11542.

${ }^{201}$ W. Zhang, J.L. Loebach, S.R. Wilson, E.N. Jacobsen, J. Am. Chem. Soc. 112 (1990) 2801-2803.

${ }^{202}$ R. Irie, K. Noda, Y. Ito, N. Matsumoto, T. Katsuki, Tetrahedron Lett. 31 (1990) 7345-7348.

${ }^{203}$ D.E. de Vos, B.F. Sels, P.A. Jacobs, Cattech 6 (2002) 14-29.

${ }^{204}$ J.H. In, S.E. Park, R. Song, W. Nam, Inorg. Chim. Acta 343 (2003) 373-376. 


\section{Summary}

In recent years, LDHs have been used for many purposes. One of these is their use as supporting materials. The anions of biologically important molecules, sensitive synthons of organic syntheses, anions of organocatalyts and, occasionally, the anionic forms of transition metal complexes were intercalated successfully in a large variety of LDHs applying a number of different methods. Works concerning the latter anions are scarce, and amino acids have never been used as ligands. Therefore, the experimental work leading to this dissertation aimed at the intercalation of $\mathrm{Mn}(\mathrm{II})-, \mathrm{Ni}(\mathrm{II})-, \mathrm{Cu}(\mathrm{II})-$ or $\mathrm{Fe}(\mathrm{III})$-amino acid complexes among the layers of CaAl-LDH in anionic form. The verification of the successful intercalation, the comprehensive structural characterization of the composites as well as the investigation of the catalytic properties were also among the main goals. The intercalation was attempted by various methods, and, finally, the transition metal complex dependent varieties of the direct anion exchange led to satisfactory results.

During the direct anion exchange $(\operatorname{method} A)$, the amino acid anions were intercalated first. For learning about the changes of the interlayer distance, XRD was applied, while the incorporation of the organic materials was followed by IR spectroscopy. In the second step, the amino acid anion intercalated samples were treated with the basic or neutral aqueous solution of the metal ions. After identifying the appropriate parameters ( $\mathrm{pH}$, amino acid:metal ion ratio), the construction of certain complexes (Mn(II)-His, $\mathrm{Cu}(\mathrm{II})-\mathrm{Cys}, \mathrm{Ni}(\mathrm{II})-\mathrm{Cys}$ és $\mathrm{Fe}(\mathrm{III})-\mathrm{Cys})$ among the layers of the LDH was successful.

In method $B$, the complexes were constructed separately and the intercalation of their anionic forms were attempted from solution. Beside the $\mathrm{pH}$ and the amino acid:metal ion ratio, the solvent mixture was also proved to be an important synthesis parameter. This method was found to be more efficient than method $A$. In this way, we could introduce the anionic forms of $\mathrm{Mn}$ (II)-Tyr, Mn(II)-Cys, Cu(II)-His, Cu(II)-Tyr, Fe(III)-His, Fe(III)-Tyr, $\mathrm{Ni}(\mathrm{II})-\mathrm{His}$ and $\mathrm{Ni}(\mathrm{II})-\mathrm{Tyr}$ complexes among the layers of CaAl-LDH.

The intercalated systems were characterized by a revealing number of experimental methods. XRD, SEM, TEM, IR, XPS and TEM were used for the description of the structure and morphology of the LDH host. The quantitative and structural characterization of the intercalated complex was performed by TEM, SEM-EDX, ICP-OES, XAS, UVVis, mid and far IR, Raman, ESR and XPS measurements as well as by molecular modelling. 
It has been found that the constructed/introduced complexes are of octahedral structure, and their coordination spheres consist of two bidentate by binding amino acids and two water molecules. The main coordinating atoms are the imidazole and the amino nitrogens, the thiolate and phenolate sulphur and oxygen, respectively, sometimes the carboxylate oxygen and the oxygens of the water molecules. The layered structure of the LDH was preserved in the composites, and the interlayer distances changed, mostly, they increased.

Each of the successfully prepared samples behaved as catalyst, and catalyzed the oxidation reactions of cyclohexene with appreciable conversion under mild reaction conditions applying either peracetic acid or the in situ formed dihydroxy iodobenzene oxidizing agents. On using the peracetic acid and the dihydroxy iodobenzene epoxide selectivity and cis diol formation were observed, respectively. The variations in the major products indicate substantial differences in the mechanisms of the transformations.

The $\mathrm{Cu}(\mathrm{II})$ - as well as the $\mathrm{Fe}(\mathrm{III})$-containing composites proved to be active and recyclable catalysts in the Ullmann-type etherification reaction, especially in the presence of certain added bases. 


\section{Köszönetnyilvánítás}

Elsősorban szeretném megköszönni az áldozatos és segítőkész munkát és azt, hogy lehetővé tették ennek a disszertációnak az elkészültét témavezetőimnek, Prof. Dr. Pálinkó Istvánnak és Prof. Dr. Sipos Pálnak. Mind szakmailag, mind emberileg nagyon sokszor és nagyon sokat segítettek az Anyag- és Oldatszerkezeti Kutatócsoporthoz való csatlakozásom óta eltelt idöben. Külön köszönettel tartozom Dr. Csendes Zitának és Dr. Ádok-Sipiczki Mónikának azért, hogy segítettek elindulni azon az úton, aminek a végén megszületett ez a munka. Dr. Peintler Gábornak köszönöm, hogy bármilyen elméleti, gyakorlati vagy emberi probléma megoldása során a segítségemre volt, akár a leglehetetlenebb időpontokban is. Köszönettel tartozom mindenkinek, aki segített a publikációim megszületésében. Így köszönetet mondok Dr. Korecz Lászlónak, Dr. Kónya Zoltánnak, Dr. Kukovecz Ákosnak és Dr. Stefan Carlsonnak.

A már említett kutatócsoport minden tagjának hálával tartozom barátságukért, segítségükért és a feledhetetlen „,eszmecserékért”. De közülük is kiemelnék néhány embert. Dudás Csilla, Dr. Ferencz Zsolt, Dr. Csankó Kriszitián, Dr. Bajnóczi Éva, Dr. Szabados Márton, Timár Zita és Ziegenheim Szilveszter, mindannyian nagyon sok segítséget nyújtottak szakmailag és emberileg.

Végül, de nem utolsó sorban óriási köszönettel tartozom páromnak, szüleimnek, testvéreimnek, rokonaimnak és barátaimnak, hogy mindig és mindenben támogattak! $:$

Az értekezéshez vezető kísérleti munkát az NKFI 106234 pályázat anyagilag támogatta. A támogatásért köszönettel tartozunk. 


\section{Függelék}

A különböző XP spektrumok bizonyították, hogy a hisztidináttartalmú kompozitok esetében sikeresen építettünk be rezet $\mathrm{Cu}$ (II)-formában (F1. ábra), ahogyan ez a XAS spektrumokból is egyértelmüen kiderült. Az is megállapítható volt, hogy a $\mathrm{Cu}(\mathrm{II})$ a sokadik felhasználás után is megmaradt a rendszerben (F2. ábra). A Ca(II) valamint $\mathrm{Al}(\mathrm{III})$ ionok is megtalálhatóak a rendszerben, amint azt az F3. és F4. ábrák mutatják. A hisztidinát aniont felépítő különféle funkciós csoportokhoz tartozó elnyelések szintén megfigyelhetők voltak, úgymint a karboxilát csoporthoz rendelhető sávok (F5. és F6. ábra), valamint az aromás C$\mathrm{N}$ kötéshez tartozó elnyelés, ami feltehetően az imidazolát csoporthoz rendelhető (F7. ábra).

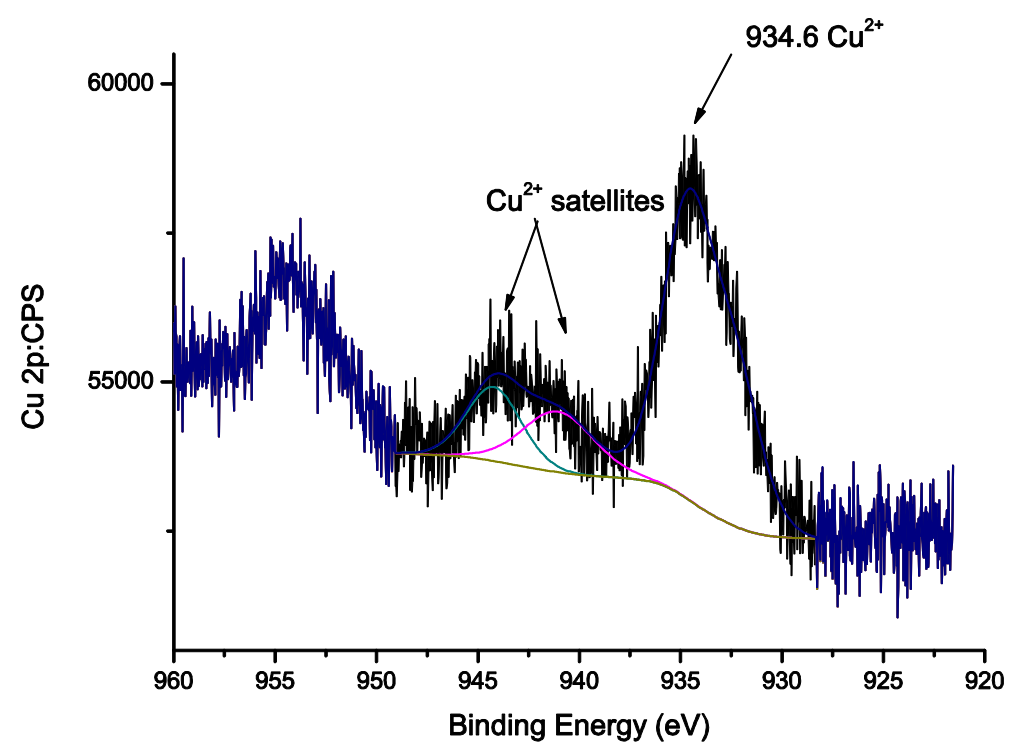

F1. ábra: $\mathrm{A} \mathrm{Cu}(\mathrm{II})$-hisztidinát-CaAl-LDH XP spektruma - a $\mathrm{Cu}$ (II) beépülésének bizonyítása. 


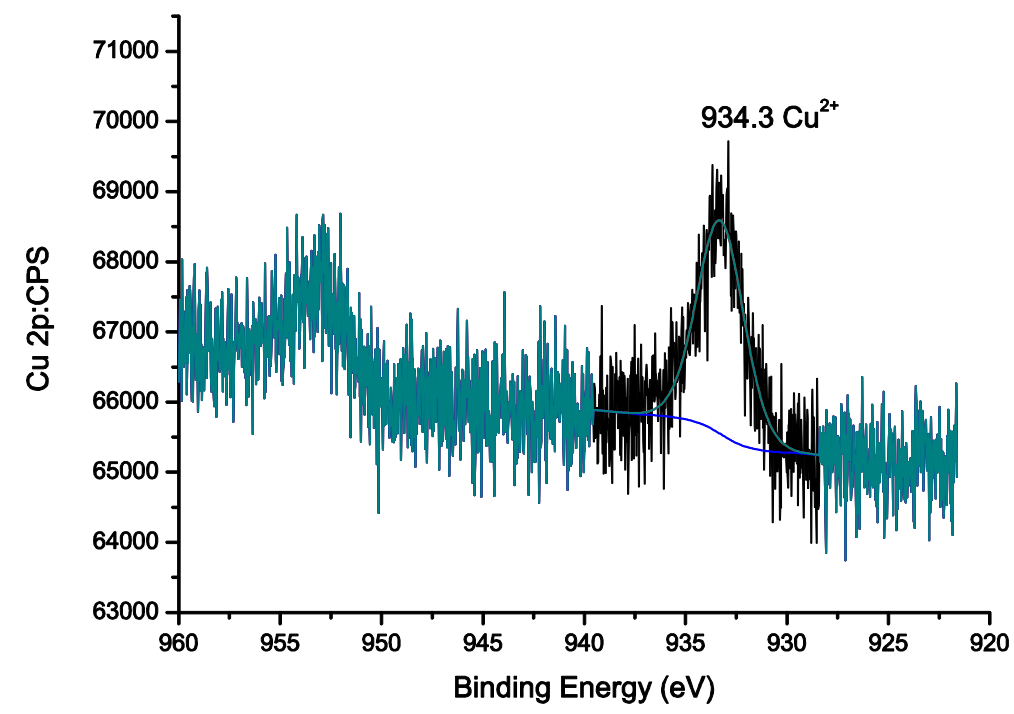

F2. ábra: $\mathrm{Cu}(\mathrm{II})$-hisztidinát-CaAl-LDH XP spektruma a ciklohexén oxidációban történő 4. felhasználás után.

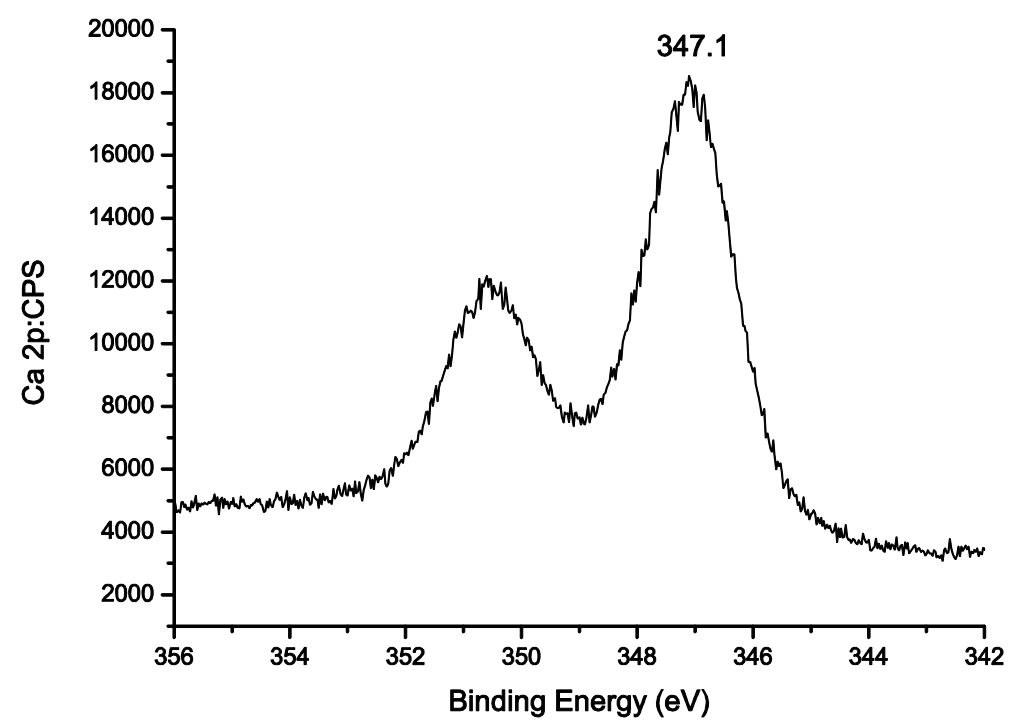

F3. ábra: $\mathrm{Cu}(\mathrm{II})$-hisztidinát- $\mathrm{Ca}_{2} \mathrm{Al}-\mathrm{LDH} \mathrm{XP}$ spektruma; a $\mathrm{Ca}(\mathrm{II})$-beépülés bizonyítása. 


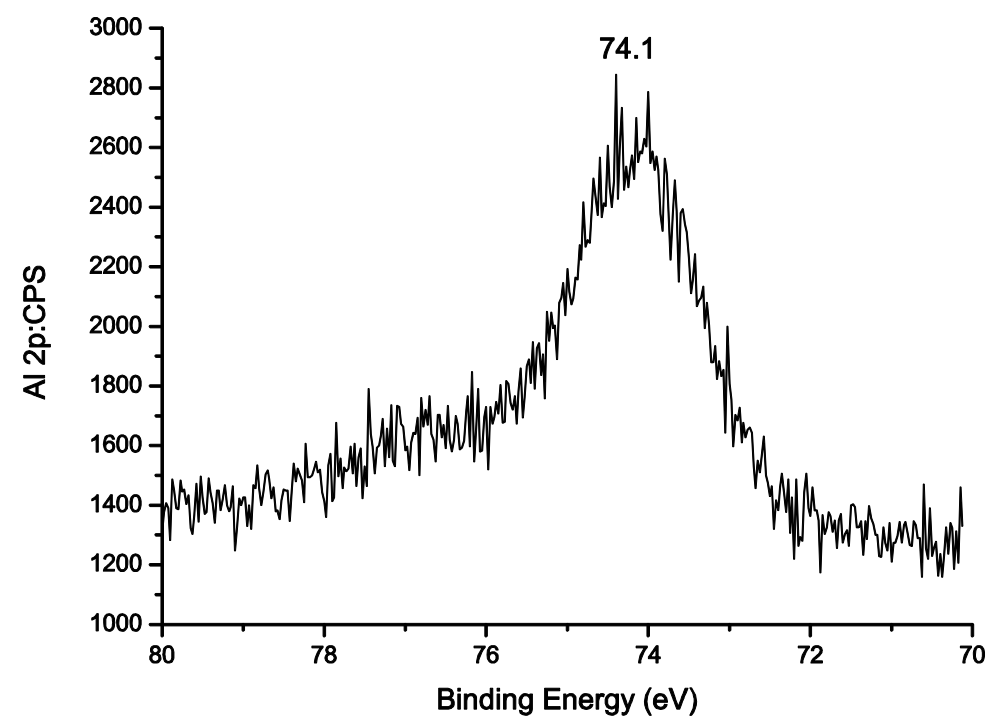

F4. ábra: $\mathrm{Cu}(\mathrm{II})$-hisztidinát-CaAl-LDH XP spektruma - az $\mathrm{Al}(\mathrm{III})$ beépülésének bizonyítása.

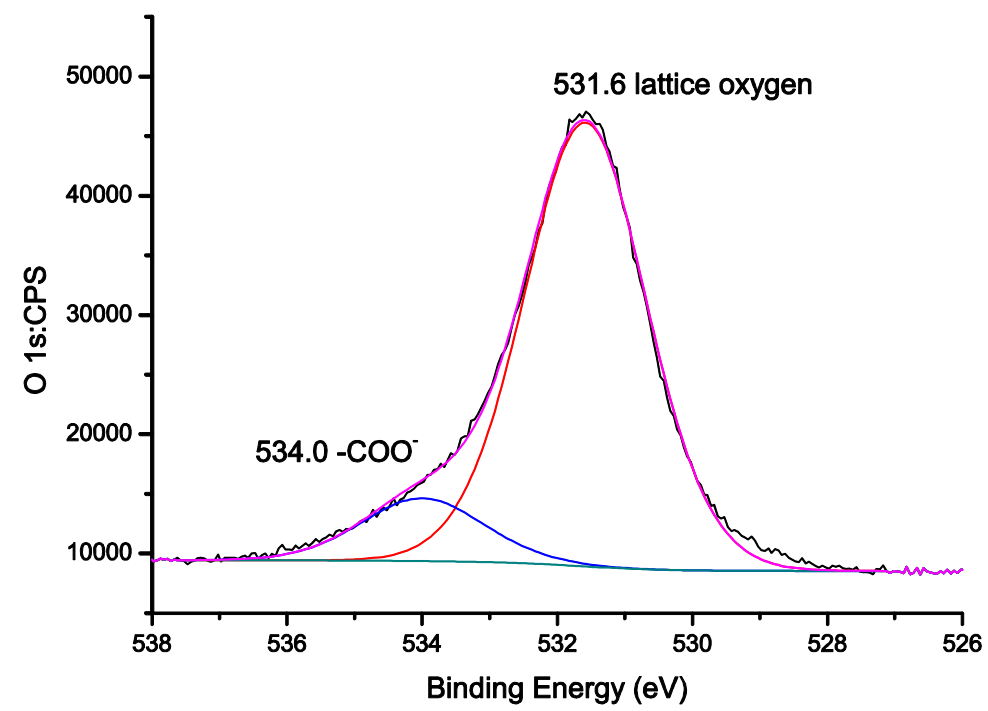

F5. ábra: $\mathrm{Cu}(\mathrm{II})-$ hisztidinát-CaAl-LDH XP spektruma - az oxigéntartalmú komponens beépülésének bizonyítása. 


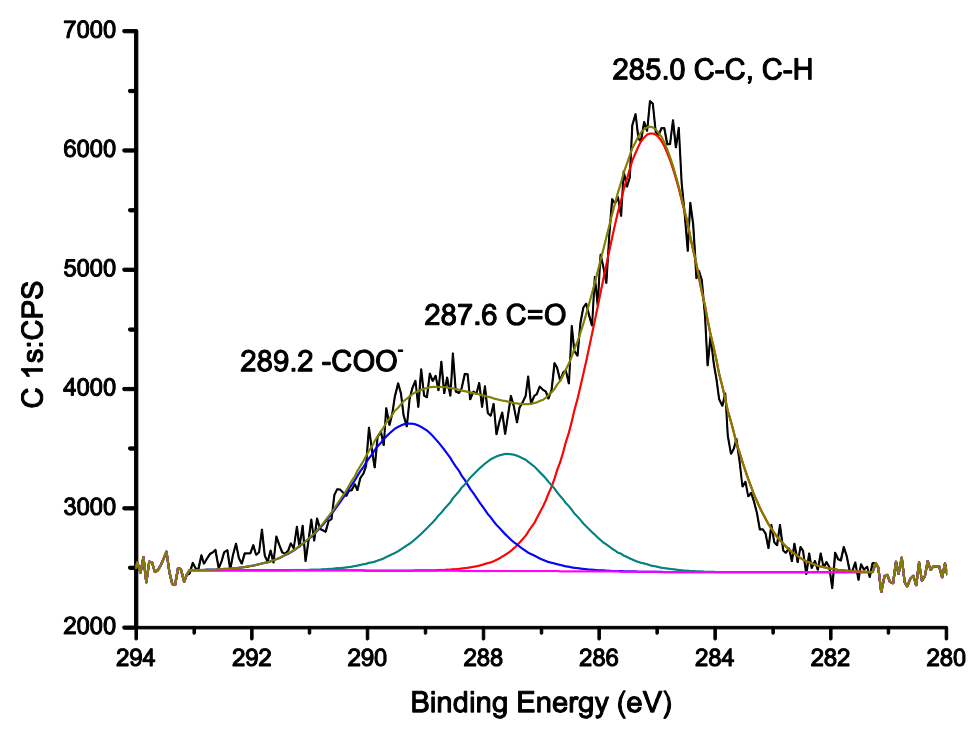

F6. ábra: $\mathrm{Cu}(\mathrm{II})$-hisztidinát-CaAl-LDH XP spektruma - a széntartalmú komponens(ek) beépülésének bizonyítása.

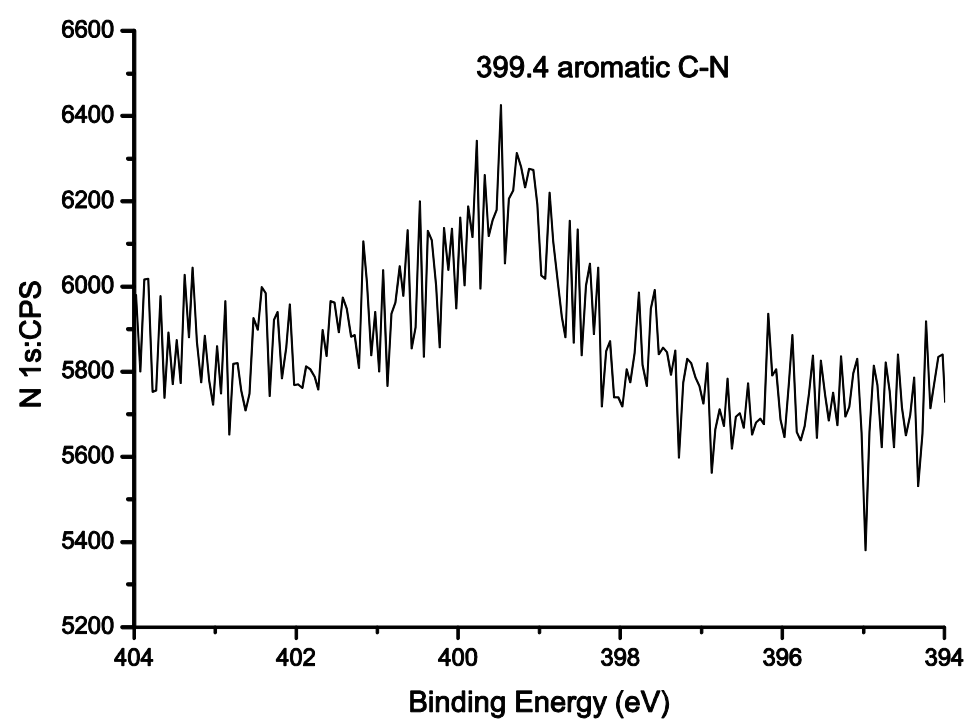

F7. ábra: $\mathrm{Cu}(\mathrm{II})$-hisztidinát-CaAl-LDH XP spektruma - a nitrogéntartalmú komponens beépülésének bizonyítása.

A TEM felvételek minden réztartalmú minta esetében bizonyították, hogy réteges szerkezet alakult ki (F8., F10. és F12. ábrák). Igazolják azt is, hogy többszöri felhasználás után sem omlott össze a réteges szerkezet (F9., F11. és F13. ábrák). 


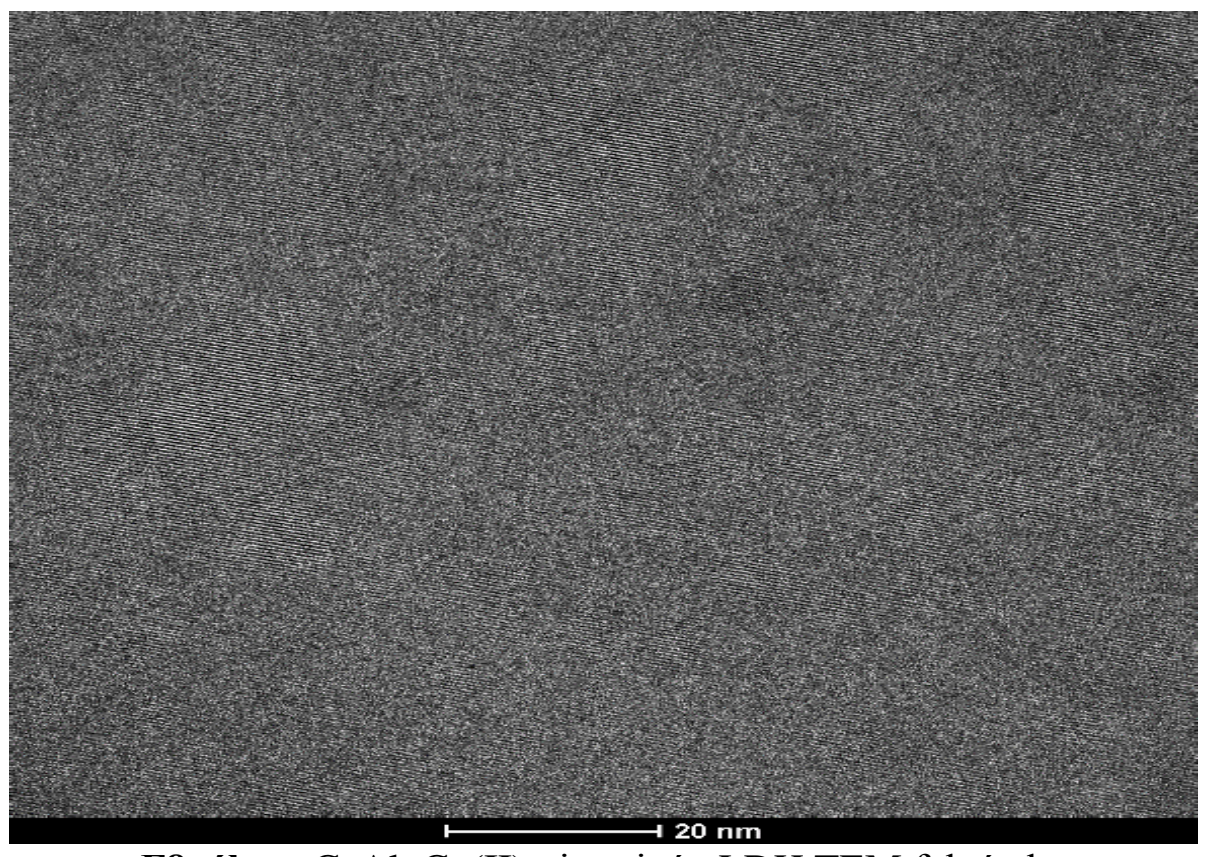

F8. ábra: $\mathrm{CaAl}-\mathrm{Cu}(\mathrm{II})$-ciszteinát-LDH TEM felvétele.

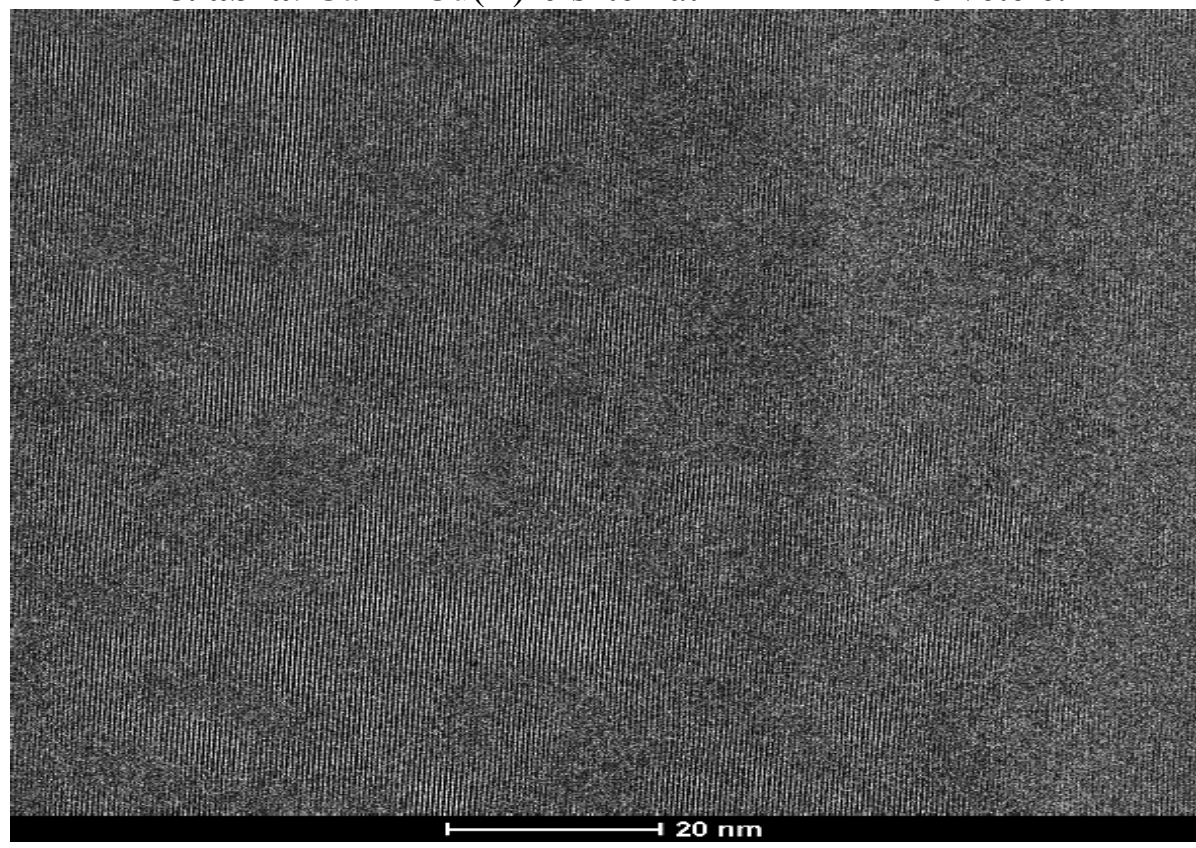

F9. ábra: $\mathrm{CaAl}-\mathrm{Cu}(\mathrm{II})$-ciszteinát-LDH TEM felvétele a ciklohexén oxidációban történő 4. felhasználás után. 


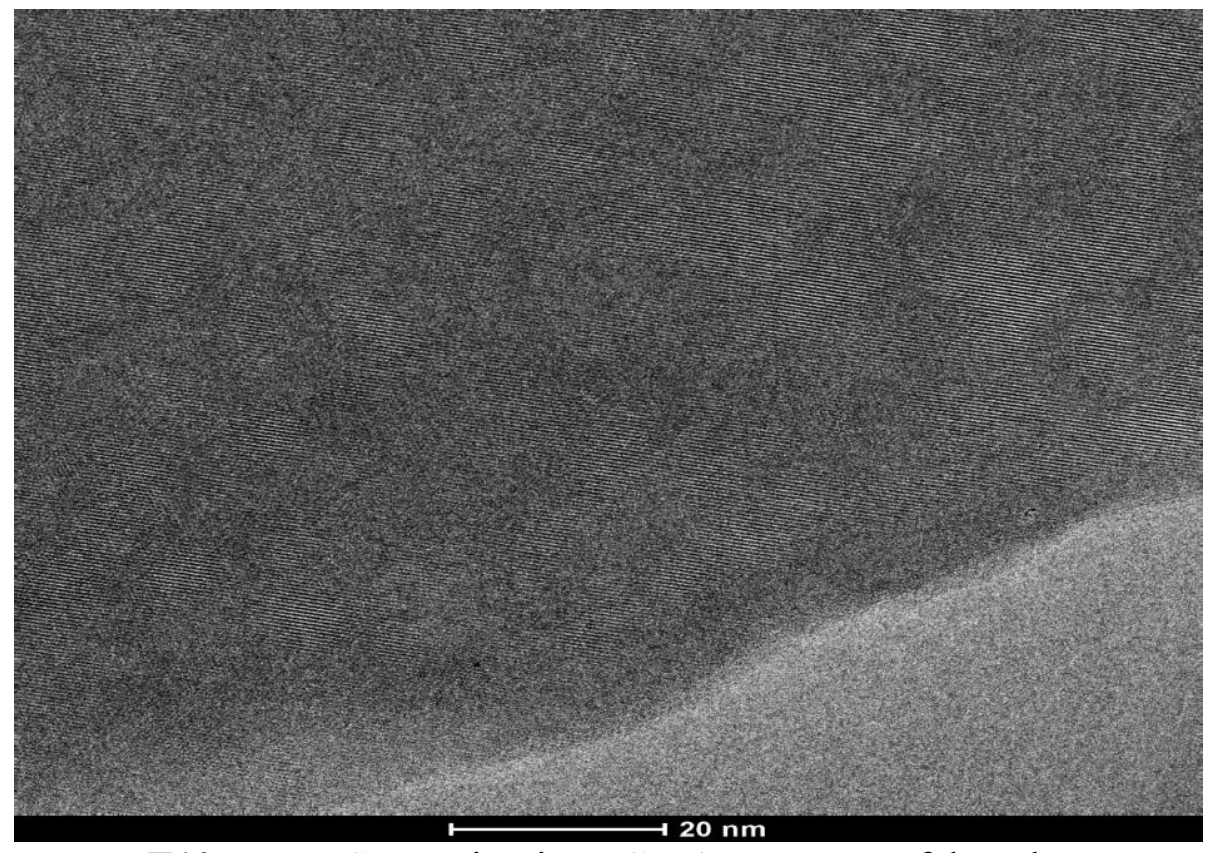

F10. ábra: $\mathrm{Cu}(\mathrm{II})$-tirozinát-CaAl-LDH TEM felvétele.

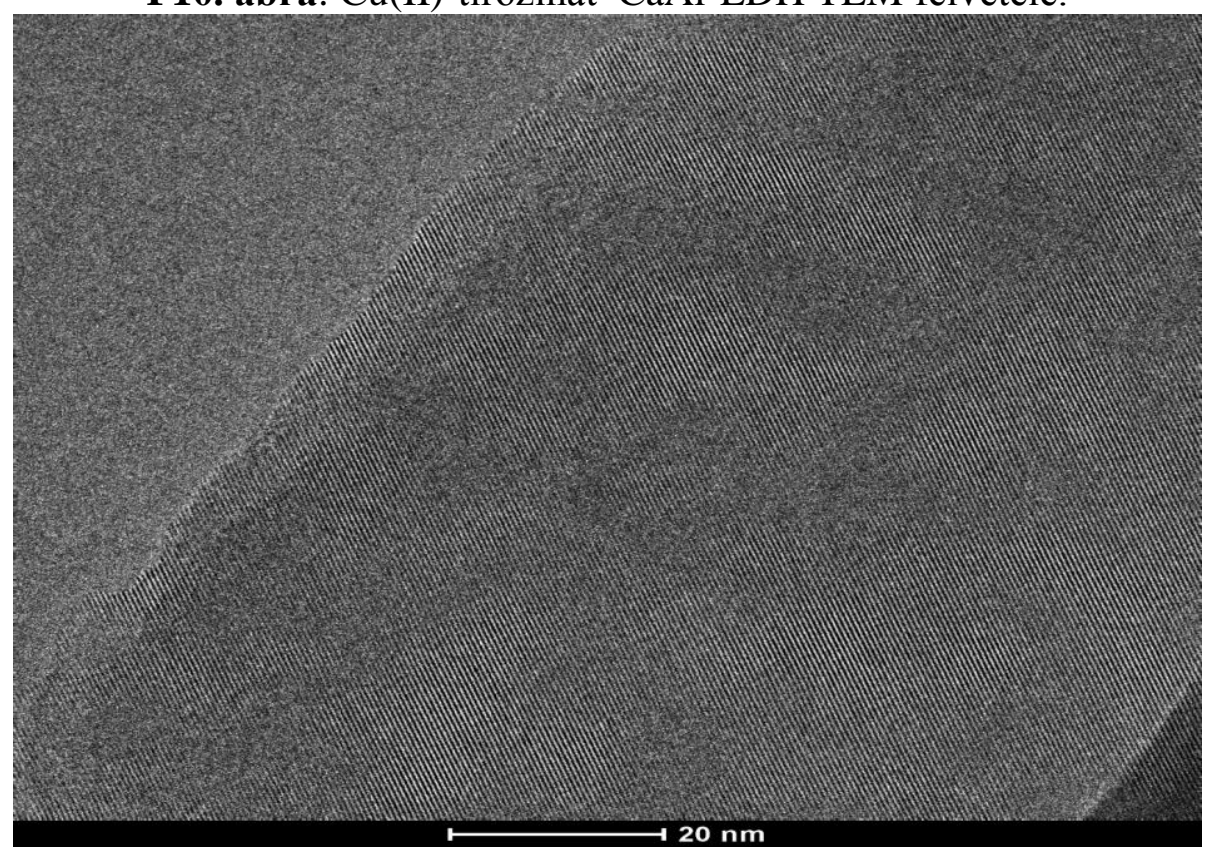

F11. ábra: $\mathrm{Cu}(\mathrm{II})$-tirozinát-CaAl-LDH TEM felvétele, a ciklohexén oxidációban történő 4. felhasználás után. 


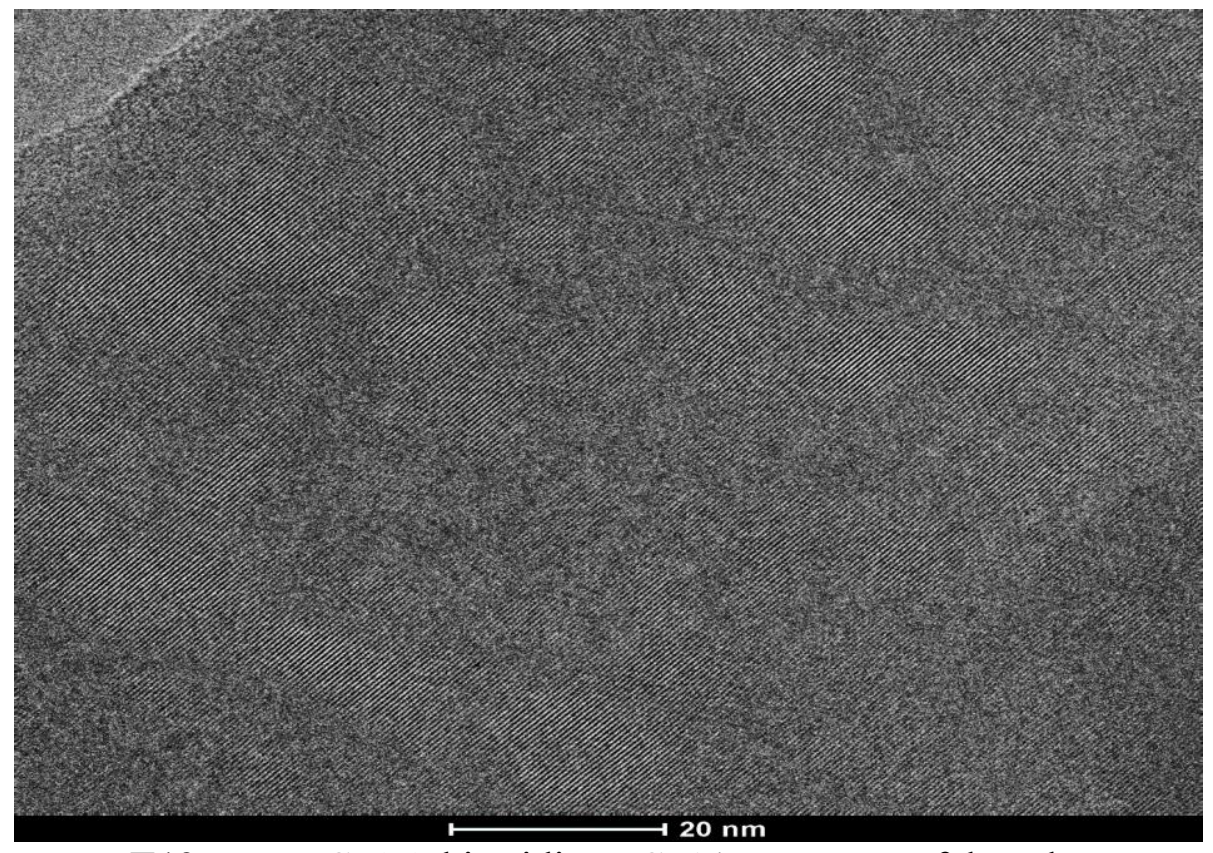

F12. ábra: $\mathrm{Cu}(\mathrm{II})$-hisztidinát-CaAl-LDH TEM felvétele.

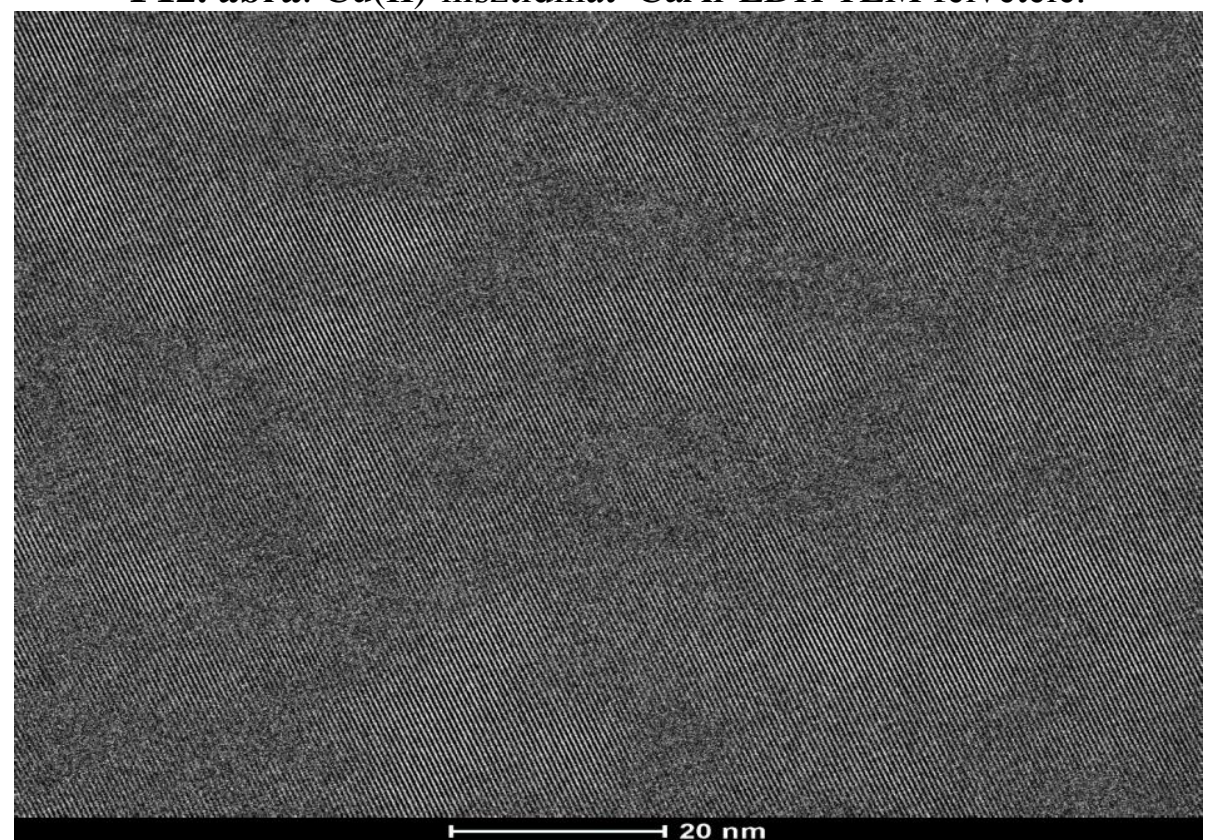

F13. ábra: $\mathrm{Cu}(\mathrm{II})$-hisztidinát-CaAl-LDH TEM felvétele, a ciklohexén oxidációban történő 4. felhasználás után. 